MATHEUS CORRÊA COSTA

\title{
ENVOLVIMENTO DA HEME OXIGENASE-1 NOS \\ MECANISMOS CELULARES DE RESPOSTA AO ESTRESSE \\ EM UM MODELO DE LESÃO RENAL AGUDA
}

Tese apresentada ao Programa de PósGraduação em Imunologia do Instituto de Ciências Biomédicas da Universidade de São Paulo, para obtenção do Título de Doutor em Ciências. 
ENVOLVIMENTO DA HEME OXIGENASE-1 NOS

MECANISMOS CELULARES DE RESPOSTA AO ESTRESSE

EM UM MODELO DE LESÃO RENAL AGUDA

Tese apresentada ao Programa de PósGraduação em Imunologia do Instituto de Ciências Biomédicas da Universidade de São Paulo, para obtenção do Título de Doutor em Ciências.

Área de concentração: Imunologia

Orientador: Niels Olsen Saraiva Câmara

Versão original 
DADOS DE CATALOGAÇÃO NA PUBLICAÇÃO (CIP)

Serviço de Biblioteca e Informação Biomédica do

Instituto de Ciências Biomédicas da Universidade de São Paulo

reprodução não autorizada pelo autor

Costa, Matheus Corrêa.

Envolvimento da Heme oxigenase- 1 nos mecanismos celulares de resposta ao estresse em um modelo de lesão renal aguda / Matheus Corrêa Costa. -- São Paulo, 2013.

Orientador: Prof. Dr. Niels Olsen Saraiva Câmara.

Tese (Doutorado) - Universidade de São Paulo. Instituto de Ciências Biomédicas. Departamento de Imunologia. Área de concentração: Imunologia. Linha de pesquisa: Imunologia de transplantes.

Versão do título para o inglês: Involvement of Heme oxygenase-1 in the cellular mechanisms of stress response in a model of acute kidney injury.

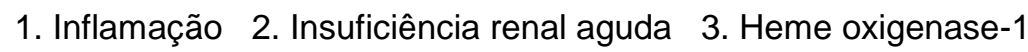

4. Monóxido de carbono 5. Estresse do retículo endoplasmático

6. Eritropoietina I. Câmara, Prof. Dr. Niels Olsen Saraiva

II. Universidade de São Paulo. Instituto de Ciências Biomédicas.

Programa de Pós-Graduação em Imunologia III. Título. 
Candidato(a): $\quad$ Matheus Corrêa Costa.

Título da Tese: $\quad$ Envolvimento da Heme oxigenase-1 nos mecanismos celulares de resposta ao estresse em um modelo de lesão renal aguda.

Orientador(a): $\quad$ Prof. Dr. Niels Olsen Saraiva Câmara.

A Comissão Julgadora dos trabalhos de Defesa da Tese de Doutorado, em sessão pública realizada a considerou
( ) Aprovado(a)
( ) Reprovado(a)

\begin{tabular}{|c|c|}
\hline Examinador(a): & $\begin{array}{l}\text { Assinatura: } \\
\text { Nome: ....... } \\
\text { Instituição: }\end{array}$ \\
\hline Examinador(a): & $\begin{array}{l}\text { Assinatura: } \\
\text { Nome: ....... } \\
\text { Instituição: }\end{array}$ \\
\hline Examinador(a): & $\begin{array}{l}\text { Assinatura: } \\
\text { Nome: ........ } \\
\text { Instituição: }\end{array}$ \\
\hline Examinador(a): & $\begin{array}{l}\text { Assinatura: } \\
\text { Nome: ....... } \\
\text { Instituição: }\end{array}$ \\
\hline Presidente: & $\begin{array}{l}\text { Assinatura: } \\
\text { Nome: ........ } \\
\text { Instituição: }\end{array}$ \\
\hline
\end{tabular}




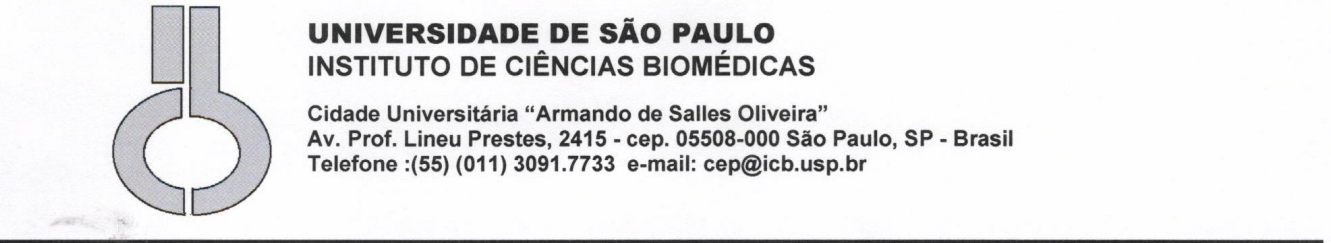

Of.CEUA. 041.13

São Paulo, 11 de junho de 2013.

\section{REF.: Protocolo n ${ }^{\circ}$ 012/10.}

"Mecanismos celulares de resposta ao estresse em modelos experimentais de insultos renais"

Prezado Professor,

Sua licença para uso de animais em experimentação, constante no protocolo em epígrafe, foi prorrogada até 25.04.2016.

Reitero que havendo alteração de metodologia e inserção de novos alunos ao projeto de pesquisa vinculado à referida licença a CEUA/ICB deverá ser informada.

Cordialmente,

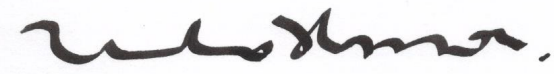

Prof. Dr. Wothan Tavares de Lima Coordenador - CEUA-ICB/ /USP 
Este trabalho foi realizado no Laboratório de Imunobiologia de Transplantes (LIT), do departamento de Imunologia, do Instituto de Ciências Biomédicas, da Universidade de São Paulo, com o auxílio financeiro da Fundação de Amparo à Pesquisa do Estado de São Paulo (FAPESP), processos 2007/07139-3, 2009/54474-8 e 2012/02270-2, do Conselho Nacional de Desenvolvimento Científico e Tecnológico (CNPq), Instituto Nacional de Ciência e Tecnologia (INCT-Complexos Fluídos) e Coordenação de Aperfeiçoamento de Pessoal de Nível Superior (CAPES). 
Aos meus pais, Geovani e Isabel, por todo amor e dedicação. Se posso dizer que cheguei aonde jamais pensaria em chegar, foi - sem dúvida graças ao carinho e sacrifício de vocês. 


\section{AGRADECIMENTOS}

Primeiramente, agradeço à Deus, fonte de toda luz e amor, por ter me oferecido tudo o que eu precisava, e, mais importante, por me fazer aprender com os obstáculos do caminho.

Ainda, seria impossível realizar esse trabalho sem a ajuda e colaboração de muitas pessoas, que se fizeram presentes durante toda essa jornada. Sendo assim, sinceramente, agradeço:

Ao meu orientador, Niels Olsen Saraiva Câmara, por todas as oportunidades, pelo apoio irrestrito, e por oferecer todas as condições para que os projetos do laboratório sejam desenvolvidos da melhor maneira possível. Obrigado pela confiança depositada em minha capacidade e por me fazer crescer profissionalmente de uma maneira que jamais imaginei que fosse possível. Por fim e não menos importante, agradeço pelos conselhos e pela amizade sincera.

À minha família - meu pai Geovani, minha mãe Isabel, meu irmão Junior, minha cunhada Gil, e meu sobrinho Pedro - pela presença em todos os momentos (mesmo quando o fuso horário era diferente!!). Vocês são a base da minha alegria e meu porto seguro. Amo vocês infinitamente!

Ao professor Leo Otterbein, por ter aberto as portas de seu laboratório na Universidade de Harvard para que eu pudesse fazer um estágio de doutorado sanduíche. Meu muito obrigado por toda preocupação com meu bem estar em um país diferente, pelas valiosas discussões científicas e pelo bom exemplo como pessoa e profissional. Agradeço também aos demais membros do laboratório: David Gallo, Barbara Wegiel, Susie Nemeth, Khalid, Eva, Mailin, Amanda, Ivy e Tania, por contribuirem imensamente para meu aprendizado e crescimento.

À minha avó Alza, tias, tios e primos, pelo carinho e orações.

Ao amigo Tárcio, irmão de caminhada, pela cumplicidade, generosidade e exemplo de ser humano demonstrados desde o início da nossa amizade, há quase 10 anos atrás. Só mesmo uma amizade verdadeira permitiria que suportássemos um ao outro por tanto tempo!! Obrigado pela ajuda nos experimentos, pelo companheirismo, pela paciência e ensinamentos. Mais do que ter sido seu colega de república ou colega de laboratório, a 
possibilidade de ter convivido com uma pessoa tão iluminada fez toda diferença durante o doutorado.

Ao amigo Reinaldo, o qual apesar de ter uma pequena diferença de idade para mim, por muitas vezes foi como um pai, sabendo dar os melhores conselhos e às vezes, mesmo que sutilmente, alguns puxões de orelha. Sua família me recebeu de braços abertos e me acolheu como um membro da mesma. Não existe outra coisa que posso dizer, a não ser muito obrigado por tudo!!

Ao amigo Vinícius, primeiramente pelo grande exemplo de descontração e alegria contagiante. Sua lealdade e camaradagem foram fundamentais em vários momentos, especialmente no período que passei nos EUA (jamais esquecerei, por exemplo, da felicidade que você e a Camila me proporcionaram com a ligação feita pra mim no dia do meu aniversário). Agradeço pelo auxílio nos experimentos, por me ensinar a ter um pensamento científico mais crítico e por todo incentivo ao longo desse período.

Aos amigos Danilo, Raphael Felizardo, Rafael Pereira, e Marquinhos, pelos momentos de descontração no laboratório e, mais que tudo, pelo companheirismo fora dele nas quartas-feiras de futebol, nas confraternizações, viagens e em tantas outras situações.

Às amigas - Mary Amano, Angela e Cris - pela ajuda nos experimentos, pela confiança depositada em mim, e, mais importante, pela forte amizade construída ao longo desses anos. Por incontáveis vezes, as conversas com cada uma de vocês me ajudou a refletir melhor sobre meus experimentos ou mesmo sobre alguma inquietude de cunho pessoal. Além disso, não poderia deixar de registrar minha admiração pela alegria e capacidade produtiva e intelectual de vocês.

Aos demais amigos do Laboratório de Imunologia Clínica e Experimental (LICE), da disciplina de nefrologia da Unifesp - Cassiano, Déborah, Clarice, Juan, Pri, Patricia Semedo, Flávia, Eliana, Fábia, Flávio, Milton, Glória e Dênis - pelos momentos de descontração e pela disponibilidade em ajudar sempre.

Aos amigos do Laboratório de Imunobiologia de Transplantes (LIT), alguns ainda presentes e outros que foram atrás de seus sonhos - Ênio, Giselle, Pedro, Rafa Larocca, Rosa, Maristella, Richardt, Carlinha, Carol Hayashida, Leminas, Daniel, Yuri Guise, André Bento, Mariana Miyagi, Marcela, Marcelli, Lis, Felipe Grabarz, Felipe Valença, Marina, Andrea Rodas, Andrea Caricilli, Guilherme, Bruno, Emily e Camila - pela convivência altamente 
saudável, pelas agradáveis discussões científicas, pelos momentos de apoio, e por colaborarem para que o LIT tenha se tornado um laboratório de referência.

À Claudinha, pela jovialidade e alegria sempre presentes, e por ajudar a manter nosso laboratório sempre em ordem. À Meire, pela prestatividade e por ter contribuído de maneira marcante para que o laboratório funcionasse de uma forma mais organizada e mais prática.

Aos amigos do departamento de Imunologia - Jean, Wesley, Cris Rossato, Andira, Verônica, Matheus Ferracini, Esther, Leandro Breda, Francisco, Cris Naffah, Lu Medina, Carininha, Maria Emilia, Marianna Koga, Narciso, Jackie, Zé, Antônio, Bruna Zelante, Isabella, Patricia Toniolo, Luciano, Camila Stumm, Grazi, Rodrigo Nalio e Lucas Faustino pela ajuda, dicas e bons momentos de amizade.

Aos funcionários do departamento de Imunologia, Eni, Jotelma, Rogerinho, Israel, Amanda, Milton, Otacilio, Seu Geraldo, Áurea, Silvana, Marlise e João, pelo bom humor constante e por não medirem esforços para ajudar e contribuir para o bom funcionamento do departamento.

Aos funcionários do Biotério de Camundongos Isogênicos do ICB IV, pelo cuidado e ajuda com os animais de experimentação, tão importantes em nossas pesquisas e sem os quais não haveria esse trabalho.

Aos professores do departamento de Imunologia do ICB IV, por contribuírem para minha formação como pesquisador, instigando meu senso crítico e pensamento científico.

Aos amigos - Tiago Jatobá, Mari Davanso, Lucinha e Nina - os quais a amizade foi cultivada durante o período da faculdade e cujos laços foram se estreitando cada vez mais nesses últimos anos. Meu muito obrigado pelos bons papos, pelos conselhos, pelas risadas, pelas horas de gordice e, principalmente, por todo carinho e amizade.

Aos demais amigos Hindiael, Ana Paula, Maria Regina, Camila Gogoni, Welbert, Vanessa, Janice, Joni, D. Léa, Guilherme Rosso, Antônio, Francis Ball, Cindy, Rafael Reis, Érica Borducci, Letícia de Castro, Michel, Isadora, Renan, Fabrício e Maria Cláudia. A presença e amizade de vocês foi e sempre será fundamental para que eu me sinta realizado como ser humano e motivado para superar qualquer contratempo.

À FAPESP, pelo apoio financeiro para a realização desse trabalho. 
"O único homem que nunca comete erros é aquele que nunca faz coisa alguma. Não tenha medo de errar, pois você aprenderá a não cometer duas vezes o mesmo erro."

Theodore Roosevelt

"A resposta certa, não importa nada: o essencial é que as perguntas estejam certas."

Mário Quintana

"É preciso força pra sonhar e perceber que a estrada vai além do que se vê!"

Marcelo Camelo 


\section{RESUMO}

CORREA-COSTA, M. Envolvimento da Heme oxigenase-1 nos mecanismos celulares de resposta ao estresse em um modelo de lesão renal aguda. 2013. $176 \mathrm{f}$. Tese (Doutorado em Imunologia) - Instituto de Ciências Biomédicas, Universidade de São Paulo, São Paulo, 2013.

A lesão de isquemia e reperfusão (IRI) continua a ser um problema clínico desafiador, especialmente em pacientes hospitalizados. Um dos principais agravantes desse insulto é a inflamação, sendo que o estresse do retículo endoplasmático (ERS) parece ser um importante mediador desse processo. Um interessante agente protetor nesse caso seria a heme oxigenase-1 (HO-1), enzima com propriedades anti-inflamatória, anti-apoptótica e imunomoduladora. Um dos subprodutos da HO-1, o monóxido de carbono (CO), parece contribuir de maneira especial para proteção a IRI, onde receptores de adenosina parecem contribuir para a estabilização do fator induzido por hipóxia (HIF-1 $\alpha)$, normalmente induzido na injúria. O objetivo do nosso trabalho foi avaliar a capacidade da HO-1 em atenuar o ERS induzido pela IRI renal, bem como o papel do $\mathrm{CO}$ e suas implicações na sinalização purinérgica e na produção de eritropoietina (EPO) na lesão renal isquêmica. Para tal, foi utilizado o modelo experimental de IRI e um grupo de camundongos C57Bl/6 foi tratado com Hemin (um indutor de HO-1) ou exposto ao $\mathrm{CO}$ antes da cirurgia. Além disso, células tubulares renais foram submetidas ao modelo de hipóxia/reoxigenação (HR). A indução da HO-1 promoveu uma proteção na IRI renal, com melhora da função renal, menos inflamação e atenuação do ERS. Ainda, o mecanismo envolvido nessa proteção parece ser mediado pela via p38 da MAPK. Ao avaliarmos um dos subprodutos da HO-1, o CO, verificamos que há também menor ativação de ERS na presença desse gás, seguido de menor disfunção renal, infiltração celular reduzida, diminuição da produção de TNF- $\alpha$ e menor hipóxia e estresse oxidativo. Além disso, houve uma regulação positiva da sinalização purinérgica anti-inflamatória após a exposição ao CO. Ainda, no grupo tratado houve uma maior estabilização de HIF-1 $\alpha$. Observou-se ainda maiores níveis séricos de EPO e maior expressão de EPOR no tecido renal nos animais expostos ao CO. Ao tratar os animais com um anticorpo neutralizante para EPO, observou-se uma perda da proteção conferida após o tratamento com CO. Quando avaliamos a atividade metabólica após o tratamento com $\mathrm{CO}$, observamos uma maior biogênese de mitocôndrias, com maior produção de ATP, aumento da proliferação celular e consequente aumento da viabilidade celular. Enfim, podemos concluir que, na presença da HO-1 ou do CO, há uma melhora da lesão isquêmica, através de uma maior ativação de vias citoprotetoras, com atenuação do ERS, redução da inflamação e consequente melhora da função renal.

Palavras-chave: Lesão renal aguda. Heme oxigenase-1. Monóxido de Carbono. Inflamação renal. Sinalização purinérgica. Eritropoietina. 


\begin{abstract}
CORREA-COSTA, M. Involvement of Heme oxygenase-1 in the cellular mechanisms of stress response in a model of acute kidney injury. 2013. $176 \mathrm{f}$. Tese (Doutorado em Imunologia) - Instituto de Ciências Biomédicas, Universidade de São Paulo, São Paulo, 2013.
\end{abstract}

Ischemia and reperfusion injury (IRI) remains a challenging clinical problem, especially in hospitalized patients. Inflammation is a major aggravating of this insult, and the endoplasmic reticulum stress (ERS) seems to be an important mediator of this process. An interesting protective agent in this case would be heme oxygenase-1 (HO-1), an enzyme with anti-inflammatory, anti-apoptotic and immunomodulatory properties. One of its byproducts, carbon monoxide (CO), seems to play a special protection for the IRI, where adenosine receptors appear to contribute to the stabilization of hypoxia inducible factor (HIF-1 $\alpha$ ), usually induced with the injury. The aim of our study was to evaluate the ability of HO-1 in attenuating the ERS induced by renal IRI, as well as the role of the $\mathrm{CO}$ and its implications for purinergic signaling and production of erythropoietin (EPO) in ischemic renal injury. For this purpose, we used an experimental model of IRI and a group of C57Bl/6 mice were treated with Hemin (an inducer of $\mathrm{HO}-1$ ) or exposed to $\mathrm{CO}$ before surgery. Moreover, renal tubular cells were subjected to the hypoxia/reoxygenation (HR) model. The induction of HO-1 promoted a protection in renal IRI with improvement of renal function, less inflammation and attenuation of ERS. Still, the mechanism involved in this protection appears to be mediated via p38 MAPK. When evaluating a byproduct of HO-1, CO, we found that there is also less activation of ERS in the presence of the gas, followed by minor renal dysfunction, reduced cellular infiltration, decreased TNF- $\alpha$ and less hypoxia and oxidative stress. Furthermore, there was an up regulation of anti- inflammatory purinergic signaling after $\mathrm{CO}$ exposure. Moreover, the treated group showed a greater stabilization of HIF-1 $\alpha$. It was also observed higher serum levels of EPO, and increased expression of EPOR in kidney tissue in animals exposed to $\mathrm{CO}$. By treating the animals with a neutralizing antibody to EPO, there was a loss of protection conferred after treatment with $\mathrm{CO}$. When we evaluated the metabolic activity after treatment with $\mathrm{CO}$, we observed a higher mitochondrial biogenesis, with greater ATP production, increased cell proliferation and consequent increase in cell viability. Finally, we conclude that, in the presence of $\mathrm{HO}-1$ or $\mathrm{CO}$, there is an better outcome of the ischemic lesion, through greater activation of cytoprotective pathways, with reduced ERS, less inflammation and consequent improvement in renal function.

Keywords: Acute kidney injury. Heme oxygenase-1. Carbon monoxide. Kidney inflammation. Purinergic signaling. Erythropoietin. 


\section{LISTA DE ABREVIATURAS E SIGLAS}

Adora - receptor de adenosina

cAMP - cyclic adenosine monophosphate

CO - Monóxido de Carbono

CORM - CO releasing molecule

CD39 - ectonucleotidase difosfohidrolase 1

CD73 - ecto5'nucleotidase

DAMPS - danger-associated molecular patterns

DRC - doença renal crônica

eIF2 $\alpha$ - fator de iniciação eucariótico $2 \alpha$

ERAD - degradação associada ao RE

ERS - endoplasmic reticulum stress

EPO - eritropoietina

EPOR - receptor de EPO

GLUT - transportador de glicose

GRP - proteína regulada por glicose

HBCOC - carreador de CO baseado em hemoglobina 
HIF-1 $\alpha$ - fator induzido por hipóxia- $1 \alpha$

HO: Heme oxigenase

HR - Hipóxia/Reoxigenação

IRI - ischemia and reperfusion injury

IL- interleucina

JNK - c-Jun quinase

KIM - Kidney injury molecule

LRA - lesão renal aguda

NF-кB - fator nuclear kappa B

NTA - necrose tubular aguda

OGD - oxygen-glucose deprived

PER2 - Period circadian protein homolog 2

PERK - proteína quinase do RE semelhante à proteína quinase ativada por RNA de dupla fita

$\operatorname{PPAR} \gamma-$ peroxisome proliferator-activated receptor gamma

ppm - partes por milhão

RE - retículo endoplasmático 
ROS - reactive oxygen species

TLR - Toll-like receptor

TNF- $\alpha-$ Fator de necrose tumoral alfa

TRAF2 - fator associado 2 do receptor do fator de necrose tumoral

UPR - unfolded protein response

VEGF - fator de crescimento endotelial vascular

XBP-1 - X-box binding protein 1

ZT - Zeitgeber time 


\section{LISTA DE ILUSTRAÇÕES}

Figura 1 - Vias de sinalização ativadas após a indução de ERS. 28

Figura 2 - Animais submetidos a IRI renal exibem uma assinatura gênica nitidamente diferente de animais controle.

Figura 3 - Tratamento com Hemin atenua a disfunção renal causada pela IRI. 62

Figura 4 - O tratamento com Hemin induz a expressão de HO-1 e inibe o processo inflamatório.

Figura 5 - A IRI renal promove ERS, condição revertida pela indução da HO-1...... 65

Figura 6 - Aumento da expressão de HO-1 em células tratadas com Hemin...... 66

Figura 7 - Indução do ERS em células renais tratadas com tapsigargina ou tunicamicina 68

Figura 8 - Ativação do ERS leva a alteração do ciclo celular e aumento do processo de apoptose.

Figura 9 - Aumento da expressão de HO-1 atenua os efeitos deletérios do tratamento com tapsigargina.

Figura 10 - Tratamento com Hemin protege as células renais submetidas a falta de glicose e oxigênio. 74

Figura 11 - Avaliação da sinalização citoprotetora após o tratamento com Hemin, no modelo de OGD 75

Figura 12 - O aumento de HO-1 atenua o processo inflamatório causado pelo OGD 76

Figura 13 - HO-1 leva a uma menor ativação do ERS no modelo de OGD.................. 78

Figura 14 - Avaliação dos níveis protéicos de marcadores de ERS. 79

Figura 15 - Ativação de AKT após tratamento com Hemin 81

Figura 16 - p38 exibe uma indução marcante após tratamento com Hemin. 82 
Figura 17 - Inibição da p38 gera uma redução da expressão de HO-1 e consequente perda do perfil citoprotetor do tratamento com Hemin

Figura 18 - Perda da ação anti-inflamatória e de inibição do ERS via HO-1 após bloqueio farmacológico da p38.

Figura 19 - O tratamento com CORM reduz a expressão de marcadores de ERS, no modelo in vivo de IRI renal

Figura 20 - O CORM promove mudança do perfil de macrófagos infiltrantes. .88

Figura 21 - Melhora da função renal de animais submetidos a IRI após o tratamento com CORM.

Figura 22 - Tratamento com CO previne a disfunção renal subsequente à IRI. 90

Figura 23 - Células renais expostas ao CO apresentam menos hipóxia e estresse oxidativo.

Figura 24 - A exposição ao $\mathrm{CO}$ reduz o número de células infiltrantes no rim e, consequentemente, o processo inflamatório 93

Figura 25 - Exposição de células renais ao CO inibe a inflamação no modelo in vitro de lesão isquêmica. 94

Figura 26 - Animais submetidos a IRI e tratados com CO exibem menos marcação para hipóxia num momento inicial após a reperfusão. 96

Figura 27 - O tratamento com $\mathrm{CO}$ reduz a inflamação inicial causada pela IRI renal.

Figura 28 - Atenuação de marcadores do ERS após a exposição ao CO 99

Figura 29 - A molécula Per2 exibe um ciclo circadiano no rim. 101

Figura 30 - Receptores de adenosina (Adora) são modulados pelo CO. 102

Figura 31 - Exposição ao CO reverte a queda da produção de ATP subsequente à lesão isquêmica e aumenta a expressão de CD39. 103 
Figura 32 - Tratamento com CO regula positivamente a sinalização purinérgica antiinflamatória

Figura 33 - CO gera uma sinalização intracelular que favorece a estabilização de HIF$1 \alpha$. 105

Figura 34 - EPO está aumentada após exposição de animais ao CO. 106

Figura 35 - Efeito do CO sobre a metabolização e produção de EPO 107

Figura 36 - A proteção vista após o tratamento com CO é mediada pela EPO. 109

Figura 37 - Aumento da disfunção renal subsequente à IRI renal em animais geneticamente deficientes para CD39. 110

Figura 38 - CO depende de CD39 para exercer seu efeito protetor.

Figura 39 - A ligação de adenosina aos receptores Adora2 é importante para a proteção após exposição ao $\mathrm{CO}$

Figura 40 - Células expostas ao CO apresentam uma mudança metabólica.

Figura 41 - Exposição ao CO aumenta a viabilidade celular.

Figura 42 - Esquema indicativo da proteção mediada pela $\mathrm{HO}-1 / \mathrm{CO}$ na lesão renal aguda. 


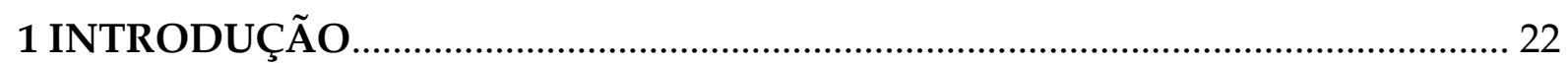

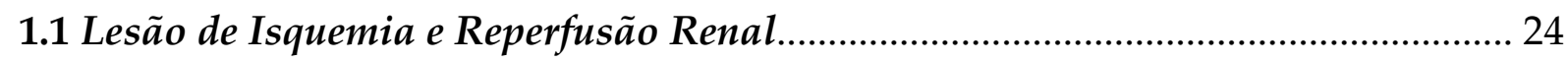

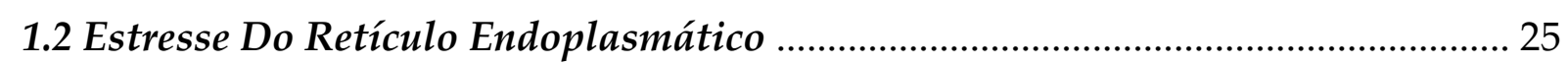

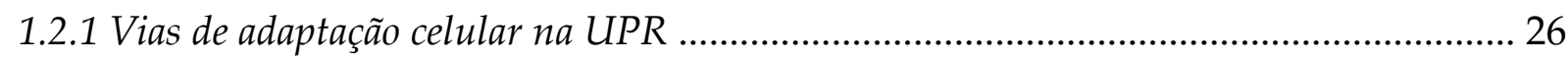

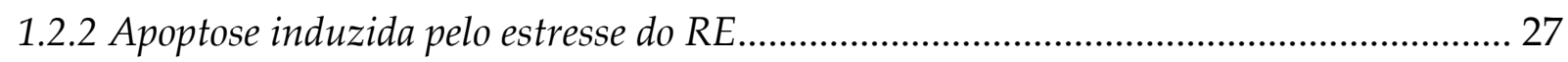

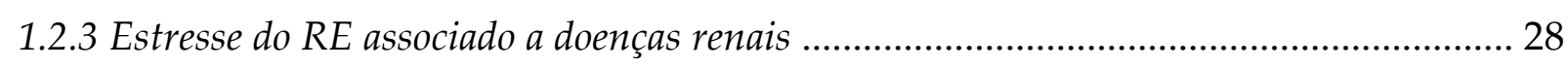

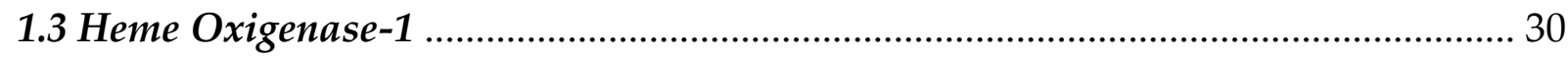

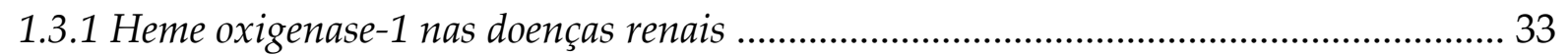

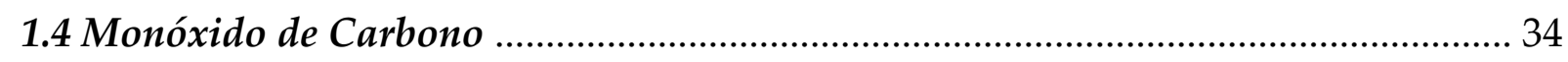

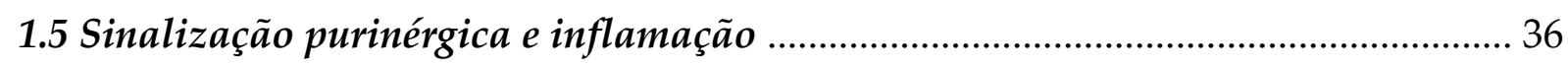

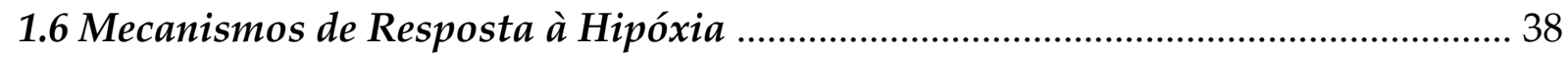

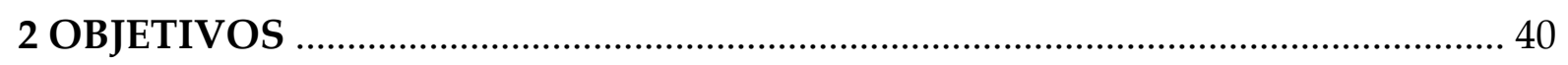

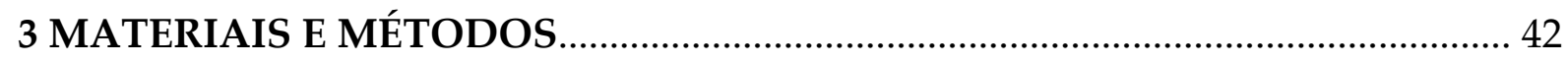

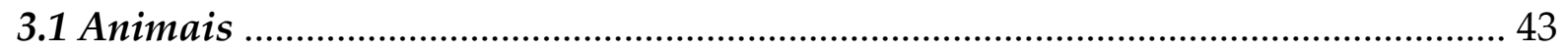

3.2 Modelo de Isquemia e reperfusão renal bilateral (IRI) ......................................... 43

3.3 Tratamentos utilizados no modelo in vivo de IRI renal ........................................ 45

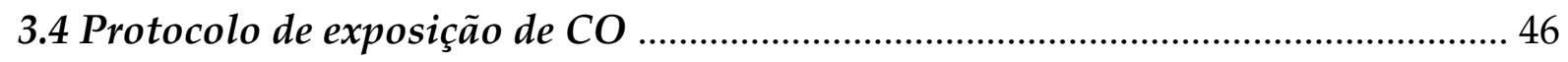

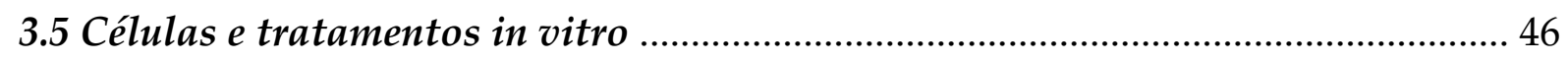

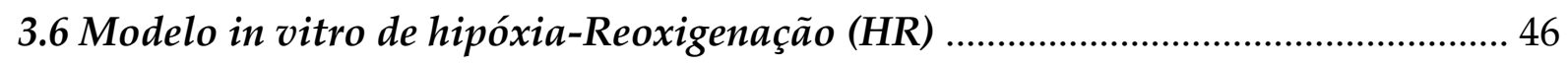

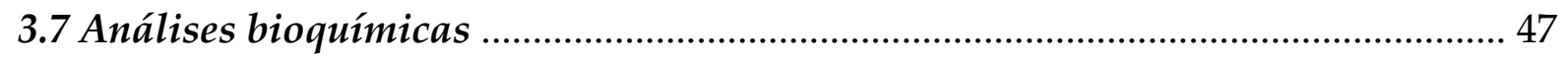

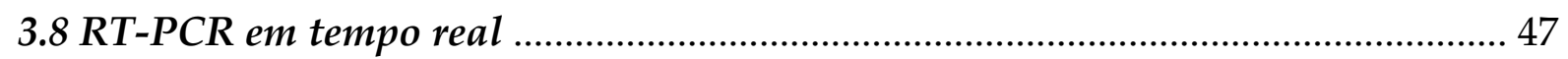

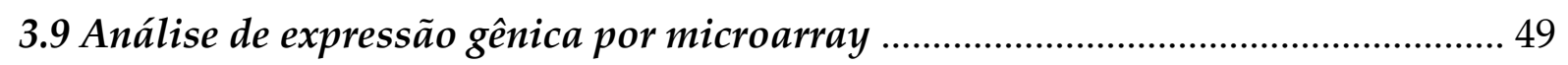

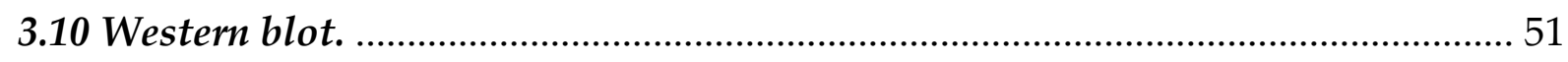

3.11 Avaliação de espécies reativas de oxigênio (ROS) e presença de mitocôndrias. 52

3.12 Dosagem de citocinas e eritropoietina (EPO) ...................................................... 53

3.13 Determinação de ATP e dosagem de lactato ....................................................... 53

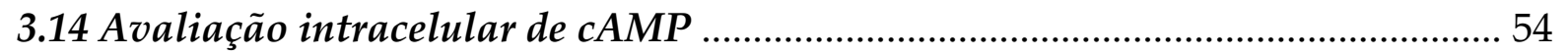


3.15 Análises histológicas 54

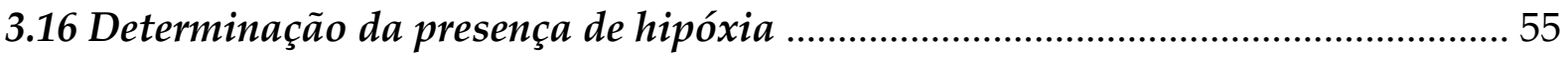

3.17 Análise de ciclo celular e apoptose por fragmentação nuclear ............................ 55

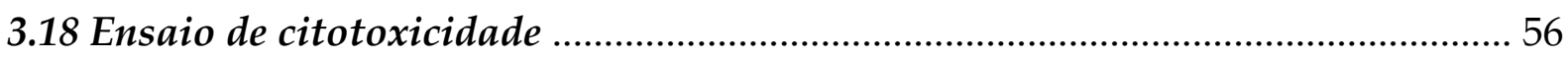

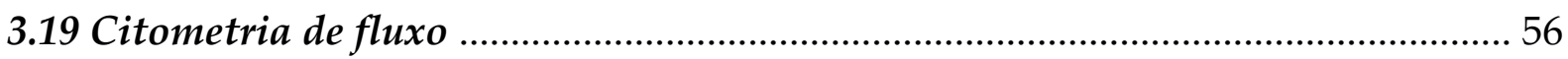

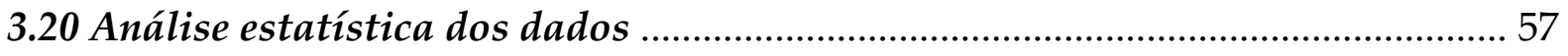

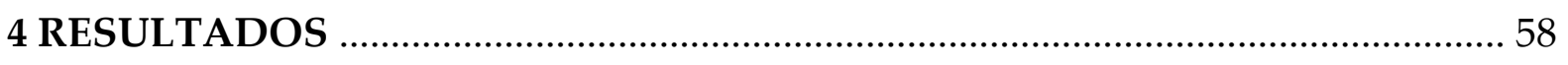

4.1 Animais submetidos a IRI exibem um perfil transcricional global diferencial. 59

4.2 O tratamento com um indutor da HO-1 leva a uma melhora da disfunção renal.

4.3 Modulação do ERS pela indução da HO-1 64

4.4 Células tubulares renais sofrem ERS frente a um estímulo farmacológico 65

4.5 A HO-1 inibe in vitro a indução do ERS causada pela tapsigargina 71

4.6 A deprivação de glicose e oxigênio são fatores agravantes da injúria celular renal. 73

$4.7 \mathrm{O}$ aumento da HO-1 atenua o ERS subsequente ao estímulo OGD 77

4.8 A proteção observada pela indução de HO-1 é mediada pela AKT e p38 MAPK. 80

4.9 A inibição da p38 leva à perda da proteção conferida pelo tratamento com Hemin. .83

4.10 Tratamento com CORM e atenuação do ERS 86

4.11 Administração de CO na forma gasosa atenua a disfunção renal causada pela IRI 89

4.12 A proteção mediada pelo CO acontece desde um estágio inicial da reperfusão. 95

4.13 O CO age via regulação positiva da molécula Per2 e da sinalização purinérgica..... 100

4.14 A EPO medeia a proteção observada após o tratamento com CO. 106 
4.15 CO depende da produção de adenosina e de sua ligação ao receptor do tipo 2

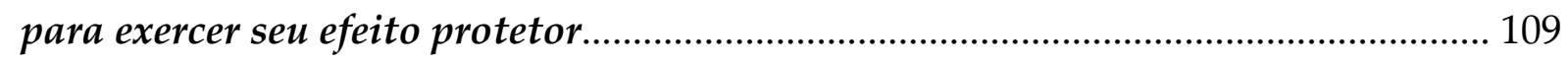

4.16 O tratamento com CO gera uma mudança metabólica nas células renais ....... 113

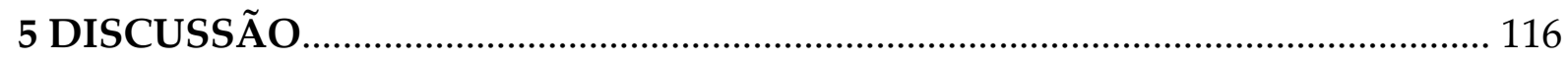

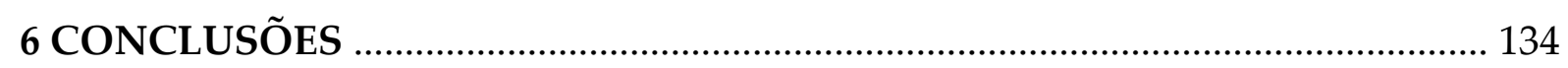

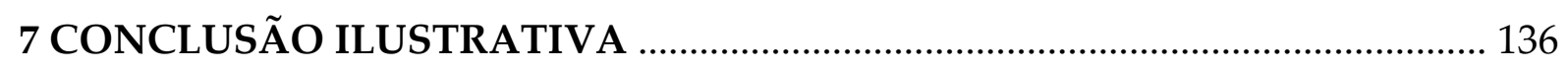

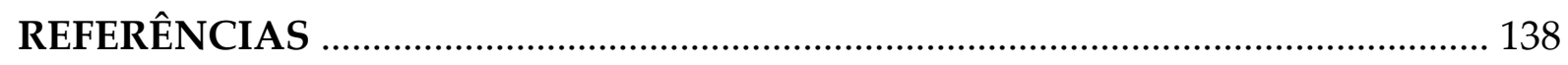

APÊNDICE - Artigos publicados ou enviados para publicação durante o

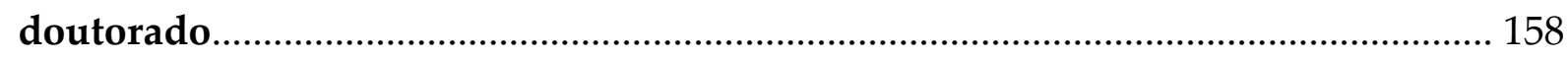


1 INTRODUÇÃO 
A lesão renal aguda (LRA) é definida como uma perda abrupta da função renal, frequentemente acompanhada de oligúria, e está fortemente associada com um aumento da morbidade e mortalidade a curto e longo prazo, além de ser um importante fator de risco para o desenvolvimento de doença renal crônica [1]. Clinicamente, a LRA é confirmada quando há uma das seguintes condições: aumento mínimo dos níveis séricos de creatinina em 0,3 mg/dL ( $\geq 26,5 \mu \mathrm{mol} / \mathrm{L})$ em 48 horas, aumento dos níveis séricos de creatinina em 1,5 vezes em relação aos valores basais (o qual presume-se que tenha ocorrido no período de uma semana), ou volume urinário menor que $0,5 \mathrm{~mL} / \mathrm{kg}$ por hora por 6 horas [2].

Além do preocupante problema da alta mortalidade associada à LRA, tal condição gera uma série de outras consequências. Pacientes com LRA consomem uma maior quantidade de recursos hospitalares, além de ficarem mais tempo internados, em parte pelos efeitos deletérios da LRA no funcionamento de outros órgãos. Por exemplo, tais pacientes possuem maior dificuldade em serem retirados da ventilação mecânica [3] e são mais propensos a edema, com subsequente elevação da mortalidade e comprometimento da recuperação renal [4]. Além disso, quando os pacientes deixam o hospital, eles geralmente levam mais tempo para se recuperarem, além de em muitos casos necessitarem de ajuda profissional especializada e muitas vezes não terem a função renal completamente restabelecida [5].

Para corroborar tais informações, um estudo feito nos EUA com mais de 4000 pacientes com diabetes tipo 2 demonstrou que aproximadamente metade desses foram hospitalizados pelo menos uma vez, e dentro desse grupo, 29\% sofreram um caso de LRA. Do mesmo modo, o mesmo estudo indicou que a LRA era um importante e independente fator de risco para a doença renal crônica (DRC) de estágio 4, e cada novo episódio de LRA dobrava esse risco [6]. Coletivamente, tais dados denotam o alto custo pessoal e governamental de um episódio de LRA e evidenciam a urgente necessidade de resolver tal problema de uma maneira efetiva. 


\subsection{Lesão de Isquemia e Reperfusão Renal}

Dentre as causas de LRA, a lesão de isquemia e reperfusão renal (IRI, do inglês ischemia and reperfusion injury) é a mais comum, sendo observada em situações nas quais o paciente sofre um transplante de órgãos, choque séptico, problemas cardiovasculares, dentre outras [7]. A IRI pode causar necrose e apoptose das células epiteliais tubulares e a disfunção renal aguda causada por insultos tóxicos ou isquêmicos é normalmente classificada como necrose tubular aguda (NTA), um termo derivado da aparência histológica dos rins [7]. Os túbulos renais são suscetíveis a lesão por hipóxia devido a diversos fatores, porém caso haja uma remoção dos elementos deletérios, tais estruturas possuem a capacidade de rápida regeneração e recuperação funcional [8].

Vários estudos com modelos animais, bem como algumas análises patológicas de biópsias humanas, demonstraram que a LRA isquêmica é marcada por uma resposta inflamatória robusta [9,10]. Além disso, estudos com roedores têm demonstrado que a resposta inflamatória à hipóxia contribui para a lesão tecidual resultante. Em modelos experimentais, terapias que inibem células específicas ou moléculas efetoras da resposta inflamatória, como proteínas do sistema complemento, quimiocinas e moléculas de adesão resultam numa melhora da LRA isquêmica [11].

Já é bem estabelecido que além do efeito citotóxico direto da hipóxia, a IRI renal leva a uma reação inflamatória no parênquima renal [9]. Tal insulto promove também a síntese de citocinas pró-inflamatórias como IL-1 $\beta$, IL-6 e TNF- $\alpha$, aumentando a infiltração de leucócitos nos rins [11-13]. É importante destacar que as células epiteliais tubulares desempenham um papel ativo no início da resposta inflamatória, com aumento da expressão de receptores do tipo Toll-like (TLR) 2 e 4, da síntese de proteínas do sistema complemento e da produção de quimiocinas [11]. A ativação dos TLRs leva à translocação nuclear do fator nuclear kappa B (NF- $\kappa \mathrm{B})$, induzindo assim à produção de citocinas e moléculas de adesão [14]. 
Durante um episódio de LRA isquêmica, uma série de mediadores inflamatórios é capaz de recrutar os leucócitos para os tecidos, e, portanto, causar uma inflamação local entre as células teciduais residentes. Tal processo ocorre inicialmente pela clivagem da fosfolipase A2, resultando numa produção elevada de ácido araquidônico, o qual é metabolizado em prostaglandinas, eicosanóides, ou leucotrienos - importantes mediadores da resposta inflamatória. Além disso, a IRI induz a produção de espécies reativas de oxigênio (ROS, do inglês reactive oxygen species), os quais podem causar a liberação de proteases, padrões moleculares associados a perigo (DAMPs, do inglês danger-associated molecular patterns) e até mesmo TNF- $\alpha$. Todos esses fatores já foram descritos como capazes de iniciar e

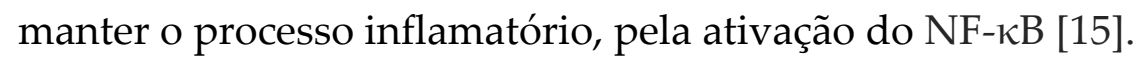

Um estudo realizado em um modelo de IRI cardíaca mostrou que durante a fase aguda da lesão isquêmica, a produção de citocinas representa uma resposta intrínseca à injúria[16]. Ainda, dentro de 15 minutos após a reperfusão, ocorre a degranulação de mastócitos residentes, liberando numerosos mediadores próinflamatórios, os quais ativam uma série de alvos, incluindo endotélio, células imune residentes ou neutrófilos infiltrantes. Como consequência, há ativação de outras células infiltrantes, como macrófagos e linfócitos, sendo que as primeiras são a principal fonte de produção de citocinas. Completando esse milieu inflamatório, estudos têm demonstrado que as próprias células estromais são capazes de produzir citocinas pró-inflamatórias, colaborando para a exacerbação desse processo [17,18].

Todas essas condições previamente descritas são importantes mediadores da LRA e um melhor entendimento dos mecanismos intracelulares que levam a tais efeitos podem ser benéficos na busca por novos alvos terapêuticos.

\subsection{Estresse Do Retículo Endoplasmático}

O retículo endoplasmático (RE) é uma organela intracelular responsável pela biossíntese de esteróides, colesterol e outros lipídios. Além disso, é local de síntese e 
empacotamento de proteínas de membrana e secretada [19]. As funções do RE são sensíveis a insultos ambientais como isquemia, restrição de glicose, estresse oxidativo ou mutações genéticas, que podem causar um empacotamento aberrante de proteínas. O acúmulo dessas proteínas aberrantes e mal empacotadas na luz do RE, por sua vez, induz uma série de disfunções nessa organela, coletivamente chamadas de estresse do retículo endoplasmático (ERS - do inglês endoplasmic reticulum stress) [20-22]. Para assegurar a fidelidade de proteínas empacotadas e evitar o acúmulo de peptídeos disformes, as células que passam pelo ERS lançam mão de um mecanismo bem conservado de resposta adaptativa, conhecido como resposta às proteínas mal empacotadas (UPR - do inglês unfolded protein reponse), a qual inicialmente objetiva atenuar a agressão, mas que pode, eventualmente, levar a morte celular se o ERS for muito severo ou prolongado [23].

O propósito primário da UPR é facilitar a adaptação ao ambiente alterado que a ativou e restabelecer as funções normais do RE. Algumas vias da UPR aumentam a capacidade de empacotamento de proteínas através da transcrição de genes alvos, como das chaperonas moleculares dependentes de $\mathrm{Ca}^{2+}$, incluindo a proteína regulada por glicose-78 (GRP78, também conhecida como BiP), GRP94 e a calreticulina [24].

\subsubsection{Vias de adaptação celular na UPR}

Existem basicamente 3 vias que promovem o retorno às funções normais do RE: a) via da IRE1, b) via da proteína quinase do RE semelhante à proteína quinase ativada por RNA de dupla fita (PERK) e c) a via do fator ativador de transcrição 6 (ATF6), os quais podem ser vistos na Figura 1. Todas essas vias são responsáveis por mecanismos únicos ou em comum que visam reduzir a quantidade de proteínas aberrantes ou mesmo evitar a formação de novas. A via de IRE1 induz principalmente a expressão de genes alvos da UPR, os ERAD (degradação associada ao RE) responsáveis pela degradação de proteínas mal empacotadas [25]. A IRE1 é ativada pela dimerização após dissociação da GRP78, e sua atividade de RNAse promove 
splicing no X-box-binding-protein-1 (XBP1), com conseqüente formação de um potente ativador transcricional de genes que formam componentes do ERAD. A via IRE1XPB1 também induz a transcrição de genes que formam as chaperonas do RE como BiP GRP94 e calreticulina [26].

A via da PERK alivia a disfunção do RE pela redução da freqüência de iniciação da tradução de RNAm e, assim, diminuir o influxo de novas proteínas no RE. A PERK é uma Ser/Thr proteína quinase, e seu homodímero ativo fosforila e inativa o fator de iniciação eucariótico $2 \alpha(\mathrm{eIF} 2 \alpha)$, e então desligando a tradução global de proteínas e reduzindo a entrada de proteínas no RE [21]. A via do PERK não apenas atenua a tradução, mas também ativa seletivamente a transcrição de genes induzidos pela UPR, incluindo chaperonas do ER e enzimas antioxidantes, como glutationa-S-tranferase e heme oxigenase, para proteger as células tanto do estresse oxidativo quanto do estresse do RE [27].

Por sua vez, a ATF6 é uma proteína regulatória que promove expressão de genes induzidos pela UPR. Após dissociação da GRP78, a ATF6 se desloca para o Golgi, onde é clivada por proteases. O fragmento citosólico clivado transloca-se para o núcleo, aonde, subseqüentemente, ativa a transcrição de genes alvos, como chaperonas e os componentes do ERAD [26,28].

\subsubsection{Apoptose induzida pelo estresse do RE}

A via de resposta ao estresse do RE está intimamente associado a indução de morte celular por apoptose. Quando as células, sob estresse do RE prolongado ou excessivo, falham em resolver os defeitos no empacotamento protéico e restaurar a homeostase, é ativada a via de apoptose [29]. Uma das principais formas de ativar essa via é pela proteína homóloga da proteína ligadora do enhancer/CCAAT (CHOP). Essa proteína é um fator de transcrição, que induz vários fatores pró-apoptóticos, além de diminuir a expressão de moléculas anti-apoptóticas, como Bcl-2, levando a maior lesão oxidante e apoptose. A atividade do CHOP em induzir apoptose é 
dependente da duração e do grau de estresse do RE. Um estresse severo preferencialmente induz expressão pró-apoptótica do CHOP quando comparado com um estresse moderado [23]. Além disso, o domínio citoplasmático da IRE-1 ativada interage com o fator associado 2 do receptor do fator de necrose tumoral (TRAF2), promovendo apoptose. O complexo IRE-1-TRAF2 ativa a via da c-Jun quinase (JNK) através da fosforilação da quinase-1 reguladora de sinal de apoptose (ASK1). IRETRAF2 também ativa a via de apoptose dependente de caspase-12 [23].

Somando a esses mecanismos, há também a presença de fatores próapoptóticos, Bax e Bak, na membrana do RE. Sob condições de estresse, esses causam liberação de $\mathrm{Ca}^{2+}$ do RE, resultando em aumento desse cátion no citosol, com conseqüente ativação de calpaína, que cliva pró-caspase-12 na sua forma ativa, induzindo assim o processo apoptótico [23], conforme observado na Figura 1.

Figura 1 - Vias de sinalização ativadas após a indução de ERS.

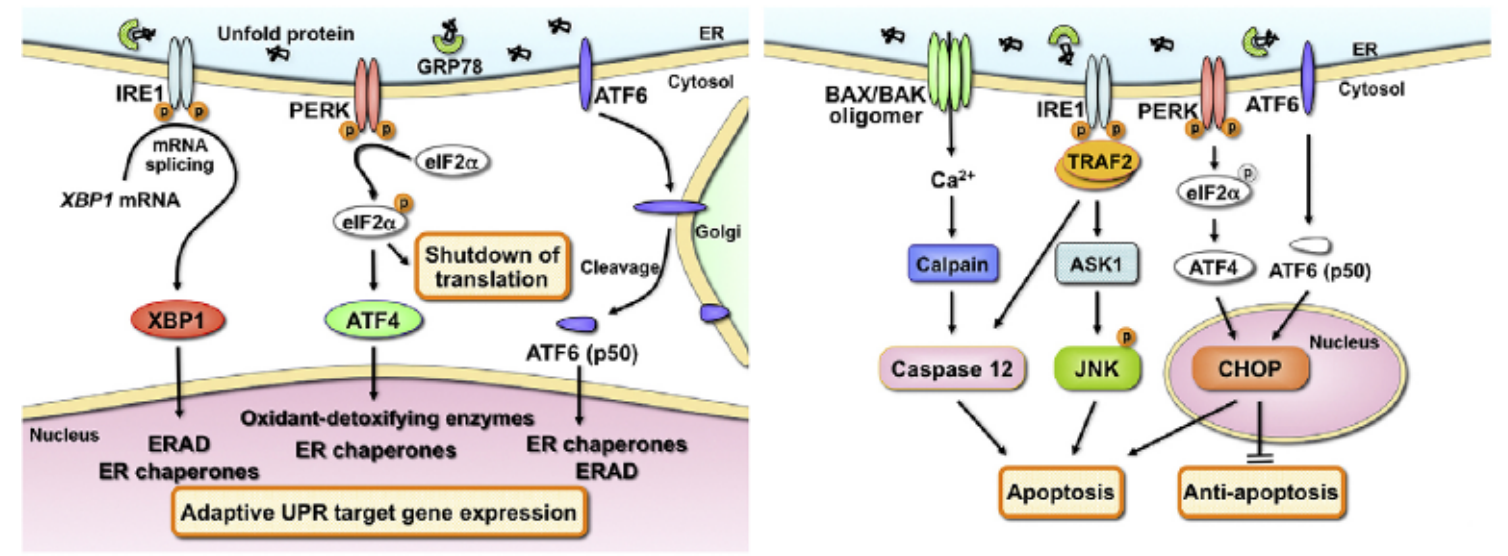

No painel da esquerda, observa-se as vias de adaptação celular da UPR. No painel da direita, vias de apoptose mediada pelo ERS.

Fonte: Inagi (2009) [23].

\subsubsection{Estresse do RE associado a doenças renais}

O estresse do RE desempenha um papel patogênico em doenças associadas ao acúmulo de proteínas aberrantes, como nas Doenças de Parkinson, Huntington e 
Alzheimer. Além disso, o estresse do RE está associado também a uma série de outras condições, como IRI, diabetes e aterosclerose [22,30-33].

A taxa de renovação de proteínas no rim é muito alta e as proteínas de membrana parecem desempenhar um papel importante nessa função. Estudos com humanos submetidos a infusões de aminoácidos marcados radioativamente indicam um turnover protéico de aproximadamente 42\% [34]. Sendo assim, as proteínas transportadoras, canais e receptores envolvidos nesse processo são sintetizados no RE e facilitam a reabsorção de glicose, água, aminoácidos, eletrólitos e pequenas moléculas [35]. Além disso, a síntese de proteínas renais diminui com a idade. Em ratos Fischer F344 este declínio é inversamente proporcional à proteinúria, sugerindo que a renovação protéica desempenha um papel fundamental na manutenção da função renal [36]. Em camundongos com mutação heterozigota da GRP78 (a mutação homozigota é letal), para retirar os efeitos da UPR, observou-se um declínio progressivo da função renal, caracterizado por glomeruloesclerose, atrofia tubular e fibrose intersticial $[37,38]$.

Estudos anteriores demonstraram também que lesão podocitária mediada pelo complemento induziu uma resposta adaptativa com aumento de expressão de chaperonas (GRP78 e GRP94) em ratos com nefropatia membranosa [39]. Outro estudo realizado por Inagi e colegas mostrou que o modelo experimental de glomerulonefrite mesângio-proliferativa leva à indução da via de UPR, incluindo aumento de chaperonas do RE e atenuação da tradução protéica pela via PERK-eIF2 $\alpha$ [40].

Assim, uma modulação dos efeitos causadores desse processo (por exemplo hipóxia, inflamação e estresse oxidativo) pode trazer um efeito protetor, levando à rápida recuperação do órgão lesado. 


\subsection{Heme Oxigenase-1}

As lesões teciduais podem ocorrer como uma consequência a diversos insultos, como hipóxia, toxicidade a drogas, hiperglicemia, ativação do sistema renina-angiotensina, entre outros. A maioria dessas lesões são caracterizadas por aumento da quantidade de estresse oxidativo, por um ambiente inflamatório e estímulos pró-fibróticos. Estes fatores influenciam na homeostase local, aumentando a injúria, a morte e/ou transdiferenciação celular. Caso o tecido lesado seja capaz de atenuar os danos celulares, este pode então promover um melhor prognóstico da doença, e, deste modo, a enzima citoprotetora heme oxigenase (HO) pode ser um importante mediador dessa proteção tecidual [41].

O heme (ferro protoporfirina IX) é parte do grupo prostético de várias proteínas e enzimas, incluindo a hemoglobina, a óxido nítrico sintase, o citocromo P450, ciclooxigenase, e catalase, entre outros. Por esse motivo, esta molécula está envolvida em funções críticas, como suprimento de oxigênio, a respiração mitocondrial e transdução de sinais [42,43]. Neste sentido, a HO, previamente descrita por Tenhunen em 1968 [44] é a enzima responsável pela degradação final do heme livre. A HO cliva o anel do heme e, como resultado, é produzido biliverdina, numa reação em que são liberados ferro livre e monóxido de carbono (CO) em quantidades equimolares. Posteriormente, a biliverdina é convertida em bilirrubina por uma enzima chamada biliverdina redutase $[45,46]$.

O sistema da $\mathrm{HO}$ consiste em duas isoformas distintas, $\mathrm{HO}-1$ (induzível) e HO-2 (constitutivo), que são produtos de genes diferentes. A HO-1 está localizada em microssomos e se encontra amplamente distribuída em tecidos de mamíferos. Além disso, em condições fisiológicas, a sua expressão é relativamente baixa. A única exceção vem do baço, onde a HO-1 é importante para a reciclagem do ferro dos eritrócitos senescentes. Estudos recentes mostraram que a deficiência de HO-1 afeta a eritropoiese e leva a redução da função e viabilidade de macrófagos fagocitadores de eritrócitos, resultando em danos nos tecidos e de redistribuição de ferro [47,48]. 
Por outro lado, a HO-2, isoforma que possui cerca de $40 \%$ de homologia de aminoácidos com a HO-1, parece funcionar como um regulador fisiológico da função das células. Ela está presente na mitocôndria, e é constitutivamente expressa no cérebro, testículos, endotélio, segmentos distais dos nefróns, no fígado e no trato gastrointestinal [49]. Finalmente, anteriormente conhecida como uma isoforma, HO-3 é agora reconhecido como um pseudogene [50].

Destas duas isoformas, a HO-1 é o mais estudado e parece proporcionar maior citoproteção. Por exemplo, a HO-1 pode agir como um antioxidante de maneira direta ou indireta. Diretamente, a enzima contribui para retirar o excesso de molécula heme que é um agente pró-oxidante [51]. Indiretamente, o ferro livre liberado a partir da sua reação estimula a expressão de ferritina, um reservatório de ferro intracelular, diminuindo a geração de radicais hidroxilas [52]. Além disso, a biliverdina e, consequentemente, a bilirrubina exibe um importante efeito antioxidante, uma vez que ambas as moléculas são scavengers de radicais livres [53].

A HO-1 também pode atuar como uma enzima imunomoduladora, especialmente em doenças mediadas por linfócitos T [54]. Um trabalho propôs que a HO-1 de células $\mathrm{T}$ contribui para a sua homeostase, mantendo esses linfócitos num estado não ativado e a inibição farmacológica de HO-1 leva à ativação e proliferação de células T [55]. A importância da HO-1 nas células T reguladoras foi descrita por estudos que indicaram que células T reguladoras constitutivamente expressam HO1, e que esta enzima pode ser induzida após expressão de FoxP3 das células T naive, conferindo um fenótipo regulador para estas [56,57]. Outro estudo mostrou que, num modelo murino de colite, o tratamento com Hemin, um indutor de $\mathrm{HO}-1$, resultou numa expansão de células $\mathrm{T}$ reguladoras e diminuição dos níveis de moléculas relacionadas ao perfil Th17. Por outro lado, a inibição da HO-1 levou a efeitos opostos, com agravamento da doença [58]. Além disso, o efeito imunomodulador de HO-1 também influencia o priming de células $\mathrm{T}$, uma vez que já foi demonstrado que a deleção do gene da HO-1 ou a utilização de siRNA em células dendríticas promoveu um aumento da expressão do complexo de histocompatibilidade principal 
de classe II, melhorando a apresentação de aloantígeno para os linfócitos T CD4 + [59].

Finalmente, a propriedade anti-inflamatória da $\mathrm{HO}-1$ pode ser devido a degradação enzimática da molécula pró-inflamatória heme, assim como a produção de seus derivados, que têm a capacidade de suprimir o processo inflamatório. No primeiro caso, o heme livre é um composto altamente tóxico e pode causar o estresse oxidativo - importante ativador da inflamação. Em adição, já foi demonstrado que a presença de heme leva a um aumento do influxo de leucócitos para os órgãos durante uma inflamação experimental [60]. Além disso, o heme é parte de muitas enzimas pró-inflamatórias, como a citocromo P450 mono-oxigenase, óxido nítrico sintase induzível e ciclooxigenase[61]. Portanto, uma vez que a HO-1 remove o heme livre excessivo, pode-se sugerir que isso vai prejudicar a atividade ótima destas enzimas, atenuando o processo inflamatório [62]. Por outro lado, alguns estudos demonstraram que a regulação positiva da HO-1 pode inibir diretamente a inflamação. Um trabalho recente indicou que, quando a HO-1 é induzida, existe uma modulação negativa de inflamação, com a diminuição da expressão de genes e produção das proteínas de TNF- $\alpha$, IL-6 e IL-1 $\beta$, com concomitantes níveis aumentados da citocina imunomoduladora IL -10 [63].

Uma das vias envolvidas neste supressão pode estar relacionada com a proteína p38 MAPK. Um estudo demonstrou que, quando ocorre uma inibição dessa proteína, a indução de HO-1 fica diminuída e, como consequência, a proteção sobre células epiteliais tubulares proximais humanas é revogada [64].

A ausência da HO-1 em humanos ou camundongos leva a uma inflamação sistêmica crônica, enfatizando a necessidade crucial dessa enzima para a regulação fisiológica no organismo, bem como sua importância na modulação das respostas ao estresse e imunes $[65,66]$.

Como a HO-1 é uma enzima de resposta ao estresse, estudos têm indicado que a sua indução confere citoproteção anti-apoptótica contra sinais de morte celular originados do estresse do compartimento do RE [33]. Além disso, foi demonstrado 
que a HO-1 inibe, in vitro, as vias de apoptose intrínseca e extrínseca induzidas por estresse [67].

\subsubsection{Heme oxigenase-1 nas doenças renais}

O primeiro trabalho que descreveu o papel da $\mathrm{HO}$ nos rins foi publicado por Pimstone et al. em 1971, sendo assim fornecidas evidências de que a indução de HO1 poderia contribuir para a citoproteção renal [68]. A imunolocalização de HO-1 em rins de ratos demonstrou que esta enzima está presente nos túbulos proximal e distal, bem como na região medular e alças de Henle [69]. Além disso, em um modelo de nefropatia diabética induzida por estreptozotocina, a HO-1 foi também expressa nos glomérulos [49]. A localização da expressão de HO-1 em diferentes doenças poderia ser importante para o desenvolvimento de medicamentos terapêuticos específicos.

Em um estudo, o qual foi utilizado um inibidor de HO-1 no modelo de IRI renal unilateral, observou-se um aumento do heme microssomal, aumentando assim a toxicidade celular. Diferente dos animais não tratados, os níveis de heme se mantiveram elevados nos animais que receberam o inibidor de HO-1 e a lesão renal foi agravada neste grupo [70]. Em contrapartida, o tratamento com um indutor de HO-1, levou a uma proteção na IRI [70,71], e promoveu uma melhora da microcirculação e menor rejeição no modelo de transplante de rim [72]. Nesse sentido, a administração de cloreto de cobalto, outro indutor da HO-1, também protegeu ratos da IRI renal, com o aumento do fator induzido por hipóxia-1 $\alpha$ (HIF-

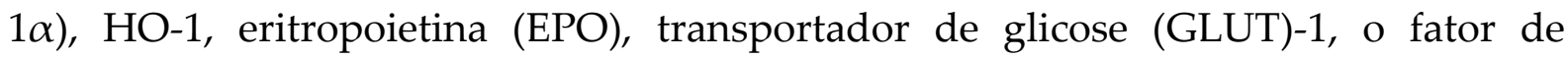
crescimento endotelial vascular (VEGF) [73]. Mais recentemente, um estudo mostrou que o tratamento com metil bardoxolone aumentou os níveis de $\mathrm{HO}-1$, protegendo os animais da IRI renal [74]. A indução da HO-1 também parece ser protetora no modelo de LRA subsequente à rabdomiólise, o tratamento dos animais com hemoglobina levou uma proteção do tecido lesado, enquanto que o uso de um 
inibidor da HO-1 exacerbou o dano renal [75]. Nesse mesmo modelo, a utilização de camundongos geneticamente deficientes para HO-1 levou a uma piora da função renal e consequente aumento da mortalidade [76], o que reforça a importância da HO-1 para diminuir o acúmulo de heme tóxico.

\subsection{Monóxido de Carbono}

Apesar de que hoje em dia há uma grande quantidade de evidências que indicam efeitos benéficos do $\mathrm{CO}$, durante décadas o $\mathrm{CO}$ foi visto como um "matador silencioso", por causa de sua forte afinidade pela hemoglobina, como um poluente ambiental ou como uma ferramenta usada por fisiologistas para estudar a distribuição de oxigênio nos leitos teciduais [77]. Realmente, altas doses de CO (> 10000 ppm) são extremamente tóxicas, porque inibem a respiração celular e interagem fortemente com a hemoglobina, restringindo a distribuição de oxigênio [78]. Porém, contra esse dogma tem-se o fato de que toda célula em um organismo de mamífero expressa HO1 [44], e portanto, tem a capacidade de gerar CO continuamente, tendo um papel fisiológico crucial no ritmo circadiano, memória e regulação hemodinâmica [79-81]. A vantagem de se usar CO como ferramenta terapêutica deriva de sua propriedade química de interagir exclusivamente com metais de transição, sendo assim uma molécula estável [82].

O mecanismo pelo qual o CO funciona é similar ao de outras moléculas sinalizadoras, como óxido nítrico e sulfeto de hidrogênio - através da amplificação de sinais intracelulares que levam a mudanças na função da célula. Além disso, uma característica particular do CO é sua capacidade em se propagar para tecidos remotos, devido a sua alta difusividade, portabilidade (via hemoglobina) e estabilidade bioquímica. Outra propriedade do $\mathrm{CO}$ diz respeito a sua facilidade em atravessar as membranas lipídicas e se ligar aos seus alvos, condição favorecida pelo seu pequeno tamanho molecular [83]. 
Apesar da via inalatória ser a forma de administração terapêutica mais simples do $\mathrm{CO}$, esse campo de estudo tem desenvolvido duas formas adicionais de distribuir esse gás - através de 1) moléculas liberadoras de CO (CORMs, do inglês CO releasing molecules) e 2) carreador de CO baseado em hemoglobina (HBCOC) $[84,85]$.

A tecnologia na qual o CORM ou HBCOC se baseiam deriva da idéia de administrar o CO conjugado a uma molécula fazendo com que esse possa ser distribuído sistemicamente ou mesmo especificamente para um tecido. Estudos recentes em modelos murinos têm demonstrado que todas essas formas de administração de CO possuem efeitos que se sobrepõem, e provavelmente os resultados dos ensaios clínicos determinarão a melhor forma a ser liberada para a prática médica [77].

O papel imunomodulador do $\mathrm{CO}$ tem recebido bastante destaque recentemente por causa de suas potentes funções anti-inflamatórias. Por exemplo, já foi demonstrado que o CO suprime a sinalização de TLR4 e bloqueia a indução de citocinas pró-inflamatórias mediadas por LPS, através da modulação de vias das MAPK [86].

Além disso, já foi descrito que o CO exerce efeitos anti-inflamatórios através da indução de PPAR $\gamma$ (do inglês peroxisome proliferator-activated receptor gamma), um receptor nuclear cuja ativação tem sido ligada a inúmeras vias fisiológicas. Nesse contexto, já foi demonstrado que a administração de CORM-2 e a indução de HO-1 aumentou significativamente a ativação de PPAR, de uma forma MAPK dependente, com subsequente atenuação do processo inflamatório [87].

Confirmando tal hipótese, um estudo indicou que o pré-tratamento com $\mathrm{CO}$ (antes da estimulação com LPS) aumentava a translocação de PPAR $\gamma$ para o núcleo de macrófagos [88]. É importante salientar que os efeitos do $\mathrm{CO}$ na modulação do $\operatorname{PPAR} \gamma$ não envolvem diretamente a interação física entre essas moléculas, mas sim o fato de que o CO leva a uma produção mínima e não deletéria de ROS mitocondrial, que direcionam uma regulação positiva de $\operatorname{PPAR} \gamma$ [89]. 
Já os efeitos protetores de $\mathrm{CO}$ em relação à morte celular já foram caracterizados em inúmeros tipos celulares, incluindo células epiteliais e endoteliais. Uma série de vias de sinalização já foram relacionadas à proteção mediada pelo $\mathrm{CO}$, incluindo p38 MAPK, guanilato ciclase solúvel e outros fatores de transdução [90]. Para ilustrar tal fato, um estudo recente indicou que o $\mathrm{CO}$ pode potencializar o turnover mitocondrial ao estimular tanto a degradação de mitocôndrias danificadas, como aumentando a biossíntese de novas mitocôndrias [91].

Na malária cerebral experimental, um modelo na qual a inflamação contribui bastante para a morbidade e mortalidade, a administração de CO 3 dias após a infecção parasitária preveniu completamente o edema cerebral, sendo que todos os animais doentes sobreviveram, ao contrário do grupo não tratado, em que a taxa de sobrevida foi de $0 \%$ [92].

O aumento do acúmulo de neutrófilos, expressão de moléculas de adesão intercelular e ativação de NF- $\kappa B$ em camundongos sépticos também estava atenuado após administração sistêmica de CORM2, um efeito que parece estar associado com produção diminuída de espécies reativas de oxigênio e óxido nítrico [93]. Ainda, a presença aumentada de CO parece melhorar a inflamação em diferentes modelos experimentais de doença, como artrite reumatóide, colite, asma [94-96]. Assim, a presença desse gás parece desempenhar um papel fundamental no combate ao processo inflamatório, atenuando assim a progressão da doença.

\subsection{Sinalização purinérgica e inflamação}

A adenosina e a HO-1 exercem uma série de ações imunomoduladoras, sendo consideradas duas importantes moléculas regulatórias. Pelo fato de ambas compartilharem propriedades anti-inflamatórias - como habilidade de inibir a iNOS e TNF- $\alpha$, e aumentar a produção de IL-10 - acredita-se que ambas possam estar molecularmente interligadas. 
Durante um insulto celular, por exemplo devido a uma injúria tecidual ou inflamação, ocorre liberação de ATP para o meio extracelular, por liberação da própria célula, ou principalmente por liberação do conteúdo citoplasmático proveniente de células mortas. Esse ATP extracelular pode sinalizar via receptores purinérgicos P2 e mediar uma série de eventos cujos efeitos finais é a ativação de vias pró-inflamatórias [97-99]. No entanto, a presença das chamadas ectoenzimas na superfície das células é capaz de regular e metabolizar a quantidade de ATP e adenosina presente no espaço extracelular[100].

Em condições inflamatórias, a adenosina extracelular é derivada predominantemente da conversão enzimática de precursores nucleotídeos ATP e ADP através da atividade enzimática da ectonucleotidase difosfohidrolase 1 (CD39) e da subsequente conversão de AMP em adenosina pela ecto5'nucleotidase (CD73). A adenosina extracelular pode então sinalizar através de 4 receptores de adenosina distintos: Adora1, Adora2a, Adora2b e Adora3. Um exemplo do papel funcional da sinalização extracelular de adenosina via receptor Adora1 pode ser descrito pelo fato de que sua ativação é utilizada para o tratamento da taquicardia supraventricular. Ainda, estudos experimentais mostram que a ativação do receptor Adora2a é importante para a atenuação da inflamação. Outros estudos experimentais forneceram evidências de que a sinalização de eventos via receptor Adora2b favorece a adaptação à hipóxia e atenuação da IRI. Por fim, um ensaio clínico mostrou que um agonista oral do receptor Adora3 pode ser útil no tratamento da síndrome do olho seco [101].

Nos rins, a adenosina regula a liberação de renina, o ritmo de filtração glomerular e o tônus vascular renal. A adenosina também é um regulador crítico do feedback túbulo-glomerular. Os níveis de adenosina estão aumentados durante estados de balanço negativo de energia, quando a taxa de hidrólise de ATP está aumentada em relação a taxa de síntese do ATP. Além disso, o aumento do consumo de ATP, uma perfusão renal comprometida e hipóxia rapidamente aumenta a 
formação de adenosina no rim. Portanto, a adenosina se acumula nos rins durante insultos patológicos [102].

Estudos recentes têm demonstrado que a sinalização via CD39 - Adora2 é protetora contra a LRA. Animais nocautes para CD39 exibiram uma maior disfunção renal após a IRI, sendo que tal lesão foi atenuada com a administração de adenosina [103]. Além disso, Crikis e colaboradores mostraram que a superexpressão de CD39 em camundongos promoveu uma proteção contra a LRA isquêmica e o uso de antagonistas do receptor Adora2 levou a uma perda da proteção observada [104]. Por sua vez, os receptores Adora2a foram detectados na microvasculatura renal, bem como nas células mesangiais e epiteliais tubulares [105-107]. A ativação dos receptores Adora2a por adenosina endógena ou agonistas exógenos produziu uma redução dramática da injúria renal provocada pela IRI [108-111]. De modo geral, acredita-se que os receptores Adora2a são protetores na LRA por modularem a inflamação renal mediada por leucócitos, enquanto que a ativação de receptores Adora2b é benéfica por estes terem um efeito direto nas células parenquimatosas renais [102].

\subsection{Mecanismos de Resposta à Hipóxia}

Uma vez que a LRA isquêmica é a principal causa de morbidade e mortalidade no curso das doenças renais, um objetivo terapêutico importante tem sido reduzir o dano que ocorre nos tecidos isquemiados. Uma maneira potencialmente atrativa para conseguir tal fato seria ativar o complexo transcricional denominado fator induzido por hipóxia (HIF-1 $\alpha$, do inglês hypoxia-inducible factor-1) [112-114]. É sabido que o HIF-1 $\alpha$ pode ser ativado por baixas tensões de oxigênio em todas as células de mamíferos e induz uma grande variedade de mudanças transcricionais. A maioria dos genes cujas expressões estão aumentadas pela HIF são aqueles que procuram aumentar a capacidade adaptativa da célula ou tecido quando o suprimento de oxigênio está reduzido [112,115], como por exemplo eritropoietina 
(EPO), transportadores de glicose, enzimas glicolíticas, fatores de crescimento angiogênico, óxido nítrico sintases e HO-1 [116-120].

É, portanto, plausível pensar que a ativação de HIF aumentaria a sobrevida de células isquêmicas e promoveria mudanças adaptativas benéficas, como aumento da angiogênese. Esse conceito é baseado em observações de que a exposição à hipóxia, num protocolo de pré-condicionamento, protegeu tecidos - cardíaco, cerebral e renal - de uma subsequente injúria isquêmica [121-123].

Dentre os genes alvos de HIF, a EPO surge em uma posição de destaque. Tal molécula é um hormônio hematopoiético produzido na vida adulta principalmente pelos rins e tem sido rotineiramente utilizado na prática clínica por aproximadamente 20 anos no tratamento da anemia. Além de seus efeitos em promover a eritropoiese a EPO também exibe um poderoso efeito tecidual protetor contra IRI em uma vasta gama de órgãos, incluindo rins, coração, fígado e sistema nervoso central [124-127]. Na condição de isquemia, o receptor de EPO é regulado positivamente [128-131] e após a ligação de seu ligante ocorre a ativação de uma série de cascatas de sinalização intracelular, incluindo MAPK, JAK-STAT, PI3K e AKT [132-134], induzindo a subsequente trancrição de genes anti-apoptóticos e antioxidantes [135,136]. Assim, a EPO surge como um eficiente agente renoprotetor contra a disfunção renal e a injúria causada pela hipóxia, estresse oxidativo e choque hemorrágico.

Dessa forma, formulamos a hipótese de que a indução da HO-1 promoveria uma atenuação do ERS nas células renais, causado pelo insulto isquêmico, com subsequente proteção da LRA. Para tal, resolvemos usar modelos in vivo e in vitro de lesão renal isquêmica e/ou hipóxica, e promover o tratamento com um indutor da $\mathrm{HO}-1$, o Hemin. Além disso, avaliamos também o papel do $\mathrm{CO}$, um dos subprodutos da HO-1, como mediador dessa proteção. 
2 OBJETIVOS 


\subsection{Geral}

Estudar os mecanismos envolvidos na modulação da resposta celular a injúria, incluindo o ERS, e a resposta inflamatória, induzido pela heme oxigenase-1 em modelos de lesão renal aguda in vitro e in vivo.

\subsection{Específicos}

Em modelos experimentais de lesão renal aguda, intencionamos:

- Avaliar a função renal de animais submetidos à IRI e que receberam ou não tratamento com Hemin;

- Verificar a expressão gênica de TNF- $\alpha$, HO-1, e moléculas relacionadas ao ERS, BiP e CHOP, com ou sem tratamento com Hemin;

- Verificar os efeitos da ERS em células epiteliais renais e sua modulação pelo tratamento com Hemin;

- Esclarecer os mecanismos pelos quais a indução da HO-1 modula o ERS;

- Avaliar a capacidade do CO em promover proteção a IRI e os mecanismos envolvidos, com enfoque na via purinérgica e nas vias intracelulares subsequentes a ativação dos receptores de adenosina; e

- Analisar o perfil metabólico celular após exposição ao CO, no modelo de lesão renal isquêmica. 
3 MATERIAIS E MÉTODOS 


\subsection{Animais}

Foram utilizados camundongos C57BL/6 machos, pesando em torno de 20 gramas, fornecidos pelo Biotério de camundongos isogênicos da Universidade de São Paulo. Os animais foram mantidos no biotério de camundongos no Laboratório de Imunobiologia de Transplantes, no ICB-IV da USP, acondicionados em gaiolas coletivas, contendo no máximo cinco animais, com ciclo artificial claro/escuro de 12 horas, a uma temperatura ambiente constante de $22^{\circ} \mathrm{C}$ e com suprimentos de água e alimento disponíveis todo o tempo. O projeto foi aprovado pelo Comitê de Ética em Pesquisa desta instituição (protocolo registrado sob n. 012, fls. 83, livro 02, do ano de 2010).

Alguns experimentos foram realizados na Universidade de Harvard, EUA. Nesse caso, camundongos isogênicos C57Bl/6 machos, na idade de 8-12 semanas (2528 g) (Charles River Animals, CT, EUA) e camundongos nocautes para CD39 (CD39KO), na mesma idade foram usados, com o background C57Bl/6, conforme descrito anteriormente [137]. Os animais tiveram livre acesso a água e comida, e todos os procedimentos foram aprovados pelo Institutional Animal Care and Use Committee (IACUC) do Beth Israel Deaconess Medical Center (BIDMC)/ Harvard Medical School, de acordo com o Guia da Associação para o Manejo e Cuidado de Animais de Laboratório (EUA), sob número de protocolo 030/2012.

\subsection{Modelo de isquemia e reperfusão renal bilateral (IRI)}

Os animais foram submetidos à anestesia com xilazina e quetamina (Agribands do Brasil Ltda, São Paulo, Brasil) por via intraperitoneal (IP), na dose de 0,004 mg/g de peso, em dose única. Os pedículos renais foram ocluídos com clipes microvasculares (Rocca, São Paulo, Brasil) por 45 minutos. Os animais foram mantidos em aquecimento por iluminação indireta até completa recuperação da anestesia. Os animais foram sacrificados em diferentes tempos após a reperfusão. 
Animais controles sofreram o procedimento cirúrgico exceto a oclusão do pedículo e foram sacrificados no mesmo tempo que os animais que sofreram isquemia.

Os animais foram divididos nos seguintes grupos:

- Controle: animais em que não ocorreu clampeamento dos pedículos renais $(\mathrm{n}=5)$.

- IRI: animais submetidos a isquemia renal por 45 minutos e reperfusão por diferentes tempos (0, 15 e 30 minutos, 2, 6, 12 e 24 horas) (n=5).

- IRI+Hemin: animais previamente tratados com Hemin e submetidos a IRI renal por 45 minutos e reperfusão por 0, 15 e 30 minutos, 2, 6, 12 e 24 horas $(n=5)$.

- CORM: animais tratados Com CORM e submetidos a isquemia renal por 45 minutos e reperfusão por 30 minutos, 6 e 24 horas $(n=5)$.

- CO: animais tratados com CO 250ppm por 1 hora $(n=5)$.

- IRI+CO: animais tratados com CO 250ppm por 1 hora e submetidos a isquemia renal por 45 minutos e reperfusão por 2, 6 e 24 horas $(n=5)$.

- rEPO+ar: animais que receberam eritropoietina recombinante e inalaram ar ambiente $(\mathrm{n}=5)$.

- $r E P O+C O$ : animais que receberam eritropoietina recombinante e inalaram $\mathrm{CO}$ 250ppm por 1 hora $(n=5)$.

- $N x+a r$ : animais que tiveram ambos os rins retirados e que inalaram ar, sendo sacrificados após 6 horas $(\mathrm{n}=5)$.

- $N x+C O$ : animais que tiveram ambos os rins retirados e que inalaram CO 250 ppm por 1 hora, sendo sacrificados 6 horas após o tratamento $(n=5)$.

- anti-EPO: animais que receberam anticorpo neutralizante para EPO e que foram tratados com CO 250 ppm e, em seguida, submetidos à IRI renal (n=5).

- IgG Controle: animais que receberam anticorpo IgG Controle e que foram tratados com CO 250 ppm e, em seguida, submetidos à IRI renal (n=5).

- CD39KO+ar: animais deficientes para CD39, submetidos à IRI renal, e sacrificados 24 hs após a reperfusão $(n=5)$. 
- CD39KO+CO: animais deficientes para CD39, que foram tratados com CO e em seguida submetidos à IRI renal, sendo sacrificados 24 hs após a reperfusão $(\mathrm{n}=5)$.

- IRI+ar+Zm241385/MRS1754: animais tratados com antagonistas dos receptores de adenosina do tipo 2, submetidos à IRI renal, com sacrifício após 24 hs (n=5).

- IRI+CO+Zm241385/MRS1754: animais que receberam CO e que foram tratados com antagonistas dos receptores de adenosina do tipo 2, submetidos à IRI renal, com sacrifício após 24 hs (n=5).

\subsection{Tratamentos utilizados no modelo in vivo de IRI renal}

Os animais foram tratados com Hemin (Frontier, Canadá), na dose de 25 $\mathrm{mg} / \mathrm{kg}$, 24 horas previamente à lesão de IRI renal ou com CORM (gentilmente cedido pela ALFAMA, Portugal), $10 \mathrm{mg} / \mathrm{kg}, 1$ hora antes da isquemia. Os antagonistas dos receptores Adora2a e Adora2b, ZM241385 e MRS1754, respectivamente, foram obtidos da Tocris Bioscience (Minneapolis, MN, EUA), e administrados na dose de 5 $\mathrm{mg} / \mathrm{Kg}$ ip 30 minutos antes do protocolo de exposição ao $\mathrm{CO}$ e 6 horas após a reperfusão. A eritropoietina recombinante (rEPO) foi obtida da eBioscience (San Diego, CA, EUA) e os animais foram tratados na dose de $5000 \mathrm{IU} / \mathrm{kg}$ ip. O anticorpo neutralizante para eritropoietina (R\&D systems, Minneapolis, MN, USA) foi reconstituído com $1 \mathrm{~mL}$ de PBS estéril e cada animal recebeu $80 \mu \mathrm{L}$ dessa solução (40 $\mu \mathrm{g}$ /animal) ip imediatamente antes da exposição ao CO e 6 horas após a reperfusão. Anticorpo IgG não-específico (R\&D systems, MN, EUA) foi usado como controle do experimento $(40 \mu \mathrm{g} /$ animal $)$. 


\subsection{Protocolo de exposição de $\mathrm{CO}$}

A exposição ao CO foi feita ao colocar os animais em uma câmara fechada na concentração de 250 partes por milhão (ppm), com ar comprimido. Os animais foram expostos ao $\mathrm{CO}$ por 1 hora antes da cirurgia.

\subsection{Células e tratamentos in vitro}

Foram utilizadas células renais epiteliais tubulares murinas imortalizadas (MM55.K), e células tubulares proximais renais porcinas (LLCPK-1), ambas obtidas da A.T.C.C., entre as passagens 10 e 20. As MM55.K foram cultivadas em meio de cultura DMEM-High (Invitrogen, Carlsbad, CA, EUA), suplementado com 5\% de soro fetal bovino. Já as LLCPK-1 foram cultivadas em meio de cultura DMEM-Low (Invitrogen, EUA), suplementadas com 5\% de soro fetal bovino. As células foram cultivadas em garrafas de poliestireno de $25 \mathrm{~cm}^{2}$, em incubadora à $37{ }^{\circ} \mathrm{C}$, umidificadas numa mistura gasosa de ar (95\%) e dióxido de carbono (5\%). Para a indução de ERS, as células foram tratadas com tapsigargina $150 \mu \mathrm{M}$ e tunicamicina $10 \mu \mathrm{g} / \mathrm{mL}$ (Sigma Aldrich, St. Louis, MO, EUA) por 12 horas. Para a indução da HO1, as células foram tratadas com Hemin (Frontier, Logan, UT, EUA) $10 \mu \mathrm{M}$ por 2 horas. Para a inibição da p38, as células foram pré-tratadas com o SP203580 (Tocris Bioscience, EUA), $10 \mu \mathrm{M}, 1$ hora antes do estímulo, sendo que o tratamento foi mantido até o término do protocolo experimental. $\mathrm{O}$ tratamento com $\mathrm{CO}$ foi feito pela exposição das células a 250 ppm de CO na forma gasosa por 4 horas antes da hipóxia.

\subsection{Modelo in vitro de hipóxia-reoxigenação (HR)}

Células renais foram cultivadas até a confluência ideal (aproximadamente $80 \%)$ e foram expostas à hipóxia $\left(0.1 \% \mathrm{O}_{2} / 5 \% \mathrm{CO}_{2}, \mathrm{~N}_{2}\right.$ para balancear) por 16 horas 
seguido de reoxigenação $\left(21 \% \mathrm{O}_{2} / 5 \% \mathrm{CO}_{2} / \mathrm{N}_{2}\right.$ para balancear $)$ por 8 horas. Para o protocolo de OGD (oxygen-glucose deprived medium), as células foram expostas a um meio contendo $\mathrm{NaHCO}_{3} 20$ mM, NaCl 120 mM, KCl 5,36 mM, Na2HPO 0,33 mM, $\mathrm{KH}_{2} \mathrm{PO}_{4} 0,44 \mathrm{mM}, \mathrm{CaCl}_{2}$ 1,22 mM, e $\mathrm{MgSO}_{4}$ 0,81 mM, e foram colocadas na sequência em hipóxia ( $1 \% \mathrm{O} 2 / 5 \% \mathrm{CO} 2 / \mathrm{N}_{2}$ para balancear) por 4 horas. Após esse período, as células tiveram o meio trocado para DMEM High e foram colocadas novamente em normóxia (por 30 e 60 minutos).

\subsection{Análises bioquímicas}

Amostras de soro ou sobrenadante de células foram processadas para dosagens de uréia e creatinina séricas ou desidrogenase lática, respectivamente, através de kits comerciais (Labtest, Sete Lagoas, MG, Brasil). Em alguns experimentos, as dosagens séricas de creatinina e uréia foram realizadas no aparelho IDEXX Catalyst DX analyzer (IDEXX Laboratories, Westbrook, ME, EUA).

\subsection{RT-PCR em tempo real}

\section{- $\quad$ Extração de RNA}

Para extração de RNA de rins coletados após o sacrifício dos animais utilizamos o Trizol (Invitrogen, EUA) e seguimos as instruções do fabricante. Após precipitação e lavagem do RNA total, foram feitas leituras da concentração de RNA obtida, usando o aparelho NanoDrop (Thermo Scientifc NanoDrop, Waltham, MA, EUA). As amostras foram consideradas de boa qualidade quando apresentavam as relações 260/230 e 260/280 iguais ou maiores que 2.

- $\quad$ Síntese de cDNA

Para síntese do cDNA incubamos $2 \mu$ g deste RNA total no tampão DNase I Reaction Buffer (Promega, EUA) e tratamos com $1 \mu \mathrm{L}$ de RNase-Free DNAse (Promega, Madison, WI, EUA) por $15 \mathrm{~min}$ a $25^{\circ} \mathrm{C}$. Em seguida adicionamos 0,5 mM de OligodT 
(Promega, EUA) e incubamos a $65^{\circ} \mathrm{C}$ por 10 min deixando no gelo por mais 5 min. Acrescentamos então $1 \mu \mathrm{L}$ BSA (Bovine Serum Albumin), o tampão M-MLV 1x, 10 $\mu \mathrm{L}$ de deoxynucleotídeo trifosfato (dNTP e) $10 \mathrm{mM}$ e $2 \mu \mathrm{L}$ enzima M-MLV Reverse Transcriptase (Promega, EUA), e novamente aquecemos a $37{ }^{\circ} \mathrm{C}$ por 60 min e $65^{\circ} \mathrm{C}$ por $10 \mathrm{~min}$.

- $\quad$ PCR em tempo real

Utilizamos sondas com primers Taqman para análise da expressão de IL-6 (Mm00446190_m1)， TNF- $\alpha$ (Mm00443258_m1), HO-1(Mm00516004_m1), BiP (Mm00517691_m1), CHOP (Mm01135937_g1) HIF-1 $\alpha$ (Mm00468878_m1), KIM-1 (Mm00506686_m1), PPAR $\gamma \quad\left(M m 01184322 \_m 1\right), \quad$ Bax (Mm00432051_m1), Bad (Mm00432042_m1) e HPRT (Mm00446968_m1) como gene normatizador. Para outros genes, foram utilizados os seguintes primers Syber, sendo a $\beta$-actina utilizada como gene normatizador:

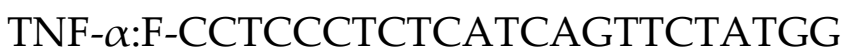

R-TGTCCCTTGAAGAGACCTGG

IL-10: F- CCAAGCCTTATCGGAAATGA

R- TTTTCACAGGGGAGAAAT

PER2: F- GGTGGACAGCCTTTCGATTA

R- AGGGCCTACCCTGACTTTGT

Adora1:F-AGAACCACCTCCACCCTTCT

R- TACTCTGGGTGGTGGTCACA

Adora2a: F-GAAGCAGATGGAGAGCCAAC

R- GAGAGGATGATGGCCAGGTA

Adora2b: F-TGCATGCCATCAACTGTATC

R- TGGAAACTGTAGCGGAAGTC

$\beta$-Actina: F-ACTGGCATTGTCATGGACTC

R- GCACAGCTTCTCCTTGATGT 
Para a reação, utilizamos $4 \mu \mathrm{L}$ de cDNA diluído 1:10, 0,5 $\mu \mathrm{L}$ de sonda, $5 \mu \mathrm{L}$ de master mix Taqman e/ou Syber e completamos o volume de $10 \mu \mathrm{L}$ com água DEPC. A amplificação foi realizada em aparelho ABI Prism 7300 sequence detection system (Applied Biosystem, Foster City, CA, EUA). As condições de amplificação foram as seguintes: $50{ }^{\circ} \mathrm{C}$ por 2 min e $95^{\circ} \mathrm{C}$ por 10 min e 45 ciclos de $95^{\circ} \mathrm{C} 15 \mathrm{seg}, 60{ }^{\circ} \mathrm{C} 1 \mathrm{~min}$. Para análise, uma relação comparativa entre os ciclos da reação (CT) foi usada para determinar a expressão gênica, em relação ao controle HPRT (gene constitutivo). Dessa maneira, níveis arbitrários de RNAm foram expressos como uma diferença de "n" vezes em relação ao calibrador. Para cada amostra, os valores (CT) dos genes alvo foram normalizados e o valor usado para demonstrar a expressão relativa dos genes alvo foi calculado utilizando-se a expressão 2- $\Delta \Delta \mathrm{CT}$ (Previamente descrita por K. Livak - PE - Applied Biosystems; Sequence Detector User Bulletin 2), sendo que nos animais controle o valor da expressão relativa foi considerada como sendo 1.

\subsection{Análise de expressão gênica por microarray}

- Extração do RNA total

O RNA foi extraído com o kit RNeasy® Mini (Qiagen, Venlo, Limburg, Holanda) junto com a etapa de tratamento com DNAse, seguindo as instruções do fabricante. Para avaliar a integridade do RNA extraído, todas as amostras foram analisadas com o auxílio do Bioanalyzer 2100 - Agilent Technologies, observando-se a presença dos RNA ribossomais 18 e 28S. O Agilent 2100 Bioanalyzer é uma plataforma baseada em tecnologia para o dimensionamento, quantificação e controle de qualidade de DNA, RNA, proteínas e células. A análise realizada pela plataforma Bioanalyzer informa de forma automatizada parâmetros do RNA como concentração e integridade, este último por meio da variável RIN (RNA Integrity Number). O RIN varia de zero a dez, indicando respectivamente de zero a cem por cento de integridade do RNA. Foram utilizadas somente amostras com RIN $\geq 8$. 
- Microarranjos de oligonucleotídeos (Agilent Technologies)

Os experimentos de hibridização para análise de expressão gênica foram realizados na plataforma Agilent. Esta plataforma utiliza bioarrays confeccionados com oligonucleotídeos de 60 bases, individualmente pré-validados. Para as análises de perfil de expressão gênica, foram utilizadas lâminas de microarranjos contendo 44.000 transcritos de transcriptoma de camundongo (Agilent Technologies Arrays, Santa Clara, CA, EUA). Os procedimentos de hibridização seguiram estritamente os protocolos fornecidos pelo fabricante. As imagens foram capturadas pelo leitor Agilent Bundle de acordo com os parâmetros recomendados para Agilent bioarrays e extraídos pelo software Feature Extraction versão 9.5.3.

A qualidade das lâminas foi analisada por meio do relatório de controle de qualidade das lâminas gerado pelo software Feature Extraction (Agilent Technologies, EUA). Esse relatório apresentou diversos parâmetros importantes para a avaliação da qualidade tais como reprodutibilidade, distribuição gaussiana dos sinais de fluorescência encontrados, comportamento similar do sinal processado e do background nas diferentes linhas e colunas do microarranjo, distribuição uniforme do background e obtenção de uma curva de comportamento linear $(R 2=0.99)$ utilizando como pontos os sinais de fluorescência obtidos de diferentes RNAs spikein. Ademais, a qualidade também foi avaliada pela análise da correlação entre a quantidade de spots e a intensidade destes utilizando o programa $R$ ( $R$ Development Core Team, 2008).

Foram refeitas as lâminas que não apresentaram enquadramento, as que possuíam mais de 50 spots saturados, além daquelas nas quais não se formou uma correlação entre a concentração de Spikeins e seus sinais processados. O valor dos spots considerados para as análises de bioinformática subsequentes foi o sinal processado (gProcessedSignal), gerado pelo software Feature Expression (v9.5.3). Foram desconsiderados os spots controles e os que não foram encontrados, ou aqueles saturados em alguma das lâminas utilizadas. 
Para determinar diferenças estatisticamente significativas no nível de expressão de cada transcrito avaliado, foi utilizado o teste estatístico SAM (Significance Analysis of Microarray). Os testes estatísticos foram realizados utilizando o programa TmeV.

- Análises de Bioinformática

Para procurar classes de ontologias GO (Gene Ontology Tree Machine) e KEGG (Kyoto Encyclopedia of Genes and Genomes) hiper-representadas no conjunto de genes diferencialmente expressos, foram comparados os transcritos diferencialmente expressos com todos os transcritos categorizados.

O estudo das redes de interação transcricional a partir dos conjuntos de genes diferencialmente expressos foi realizado utilizando a ferramenta exploratória FunNet (http://www.funnet.info). Para visualizar os resultados gerados pelo FunNet e gerar as redes de interação transcricional, foi utilizado o software Cytoscape, o qual possui um plug-in para o FunNet, conhecido como FunNetViz.

As redes de co-expressão foram construídas imputando os dados contendo os cálculos de correlação (Coeficiente de Pearson) entre os genes diferencialmente expressos no programa Cytoscape.

\subsection{Western blot}

Breve, aproximadamente $25 \mu \mathrm{g}$ de proteína total, obtido do tecido renal, foram diluídos em tampão de amostra (Biorad, Hercules, CA, EUA), contendo $20 \mathrm{mg} / \mathrm{ml}$ de 2- $\beta$-mercaptoetanol (Sigma, EUA). A seguir as proteínas foram desnaturadas por aquecimento de 5 minutos a $95{ }^{\circ} \mathrm{C}$ e separadas por eletroforese em gel de poliacrilamida $10 \%$. Posteriormente, as proteínas foram transferidas para uma membrana de nitrocelulose, sendo esta bloqueada 1 hora com leite 5\% dissolvido em TBS-T, e a seguir incubada com o anticorpo primário diluído em TBS-T overnight. A seguir, a membrana foi lavada com TBS-T e incubada por 1 hora com o anticorpo secundário. Na sequência, a membrana foi lavada novamente e exposta ao revelador 
ECL. Em seguida, a massa molecular das proteínas foi determinada por comparação com a migração das proteínas padrão Rainbow ou Dual-Color (BioRad Laboratories, EUA). Foram utilizados os seguintes anticorpos: da Cell Signaling (Beverly, MA, EUA) - BiP (3183), CHOP (2895S), phospho-ERK (9101), total ERK (4695), PGC-1 $\alpha$ (2178), phospho-p38 (4511S), total p38 (9212S), total AKT (4691S), phospho-AKT S473 (4060S) e phospho-AKT T308 (2965S) - , da Santa Cruz (Dallas, Tx, EUA) - phosphoeif2 $\alpha$ (sc-293100), total-eif2 $\alpha$ (sc-133132) e EPOR (sc-697P) - e HIF-1 $\alpha$ (NB100-105 ) (Novus, Littleton, CO EUA).

\subsection{Avaliação de espécies reativas de oxigênio (ROS) e presença de mitocôndrias}

A geração de ROS intracelular foi medida usando o composto 2',7'diclorofluorescina diacetato (DCF-DA; na concentração final de $10 \mu \mathrm{M}$ - Life Technologies, Carlsbad, CA, EUA), com posterior análise por microscopia de fluorescência. As imagens foram adquiridas com uma câmera Olympus (excitação $488 \mathrm{~nm}$, emissão $535 \mathrm{~nm}$ ). Foi também avaliada a geração de estresse oxidativo de origem mitocondrial pelo ensaio de MitoSOX ${ }^{\mathrm{TM}}$ Red Mitochondrial Superoxide Indicator (Life Technologies, EUA), também ficando na concentração final de $10 \mu \mathrm{M}$, seguindo as orientações do fabricante. Já para a marcação de presença de mitocôndria, utilizou-se o composto MitoTracker ${ }^{\circledR}$ Red CMXRos (Life Technologies, EUA), utilizado na concentração final de $500 \mathrm{nM}$, seguindo as orientações do fabricante. Em resumo, após o fim do protocolo experimental, o meio foi removido, seguido de lavagem com PBS e adição do composto (DCF-DA, Mitosox ou Mitotracker), por 30 minutos, na temperatura de $37{ }^{\circ} \mathrm{C}$. Na sequência, essa solução foi removida, e adicionou-se PBS à células. Em seguida, foi feita a análise por microscopia de fluorescência (DCF-DA e Mitotracker) ou por citometria de fluxo (Mitosox). 


\subsection{Dosagem de citocinas e eritropoietina (EPO)}

Os níveis protéicos de TNF- $\alpha$ e EPO foram determinados por ELISA (R\&D Systems, EUA), de acordo com as instruções do fabricante. Brevemente, o anticorpo de captura foi diluído na concentração de uso, distribuído nos poços de uma placa de 96 poços, e deixado incubado overnight. No dia seguinte, os poços foram lavados, seguido de adição das amostras ou curva padrão e incubação de 2 horas. Após nova lavagem, foi adicionado o anticorpo de detecção, o qual ficou em incubação por mais 2 horas. Em seguida, adicionou-se a solução de estreptavidina-HRP, com posterior adição de solução de substrato (uma mistura de $\mathrm{H}_{2} \mathrm{O}_{2}$ e tetrametilbenzidina). A reação foi interrompida após a adição de uma solução de $\mathrm{H}_{2} \mathrm{SO}_{4}, 2 \mathrm{~N}$ ). Em seguida, foi feita a leitura a $450 \mathrm{~nm}$.

Ainda, as citocinas TNF- $\alpha$, IL-6 e IL-10 foram quantificadas no sobrenadante de células em cultura pela metodologia de CBA, seguindo as instruções do fabricante (Mouse Inflammation kit, BD Biosciences, San Jose, CA, EUA), Os resultados foram determinados em pg/mL. Para análise dos dados, foi utilizado o software FCAP Array (BD Biosciences, EUA).

\subsection{Determinação de ATP e dosagem de lactato}

Os níveis de ATP do sobrenadante e do conteúdo intracelular, assim como os níveis intracelulares de lactato foram determinados usando um ensaio fluorimétrico (Biovision, San Francisco, CA, EUA), de acordo com as instruções do fabricante. Brevemente, as amostras foram coletadas e dilúidas em tampão específico de cada ensaio, sendo distribuídas nos poços de uma placa de 96 poços. Em seguida, foi adicionado um mix contendo o tampão, uma mistura de enzimas e um corante. Após incubação por 30 minutos, foi feita leitura por método fluorimétrico e a quantificação foi feita baseada no protocolo indicado pelo fabricante. 


\subsection{Avaliação intracelular de cAMP}

Os níveis de cAMP foram medidos por um kit de ELISA (Enzo Life Sciences, NY, EUA) seguindo as instruções do fabricante. Os níveis de cAMP foram normalizados pela concentração de proteína e o resultado é mostrado como pmol de cAMP por mg de proteína total.

\subsection{Análises histológicas}

Durante o sacrifício dos animais, um dos rins foi retirado, e após seccionada e retirada a cápsula renal, foi cortado sagitalmente em dois fragmentos aproximadamente simétricos. O material foi fixado em formol a 10\% tamponado, até a montagem em blocos de parafina. Após processamento habitual, foi estudado pelo menos um corte de cada fragmento, na coloração de hematoxilina-eosina (HE). Para a avaliação de células infiltrantes, realizou-se o processo de imunohistoquímica (IHQ). Para tal, os rins foram processados e incluídos em parafina e cortes de $5 \mu \mathrm{m}$ foram realizados. A técnica foi realizada utilizando o método de peroxidase com anticorpos primários específicos para macrófagos (F4/80) ou neutrófilos/granulócitos (GR1), ambos obtidos da BD Bioscience (EUA). Inicialmente foi feita a recuperação antigênica com tampão citrato $10 \mathrm{mM}, \mathrm{pH}$ 6,0. Em seguida, foi adicionada aos cortes a solução de bloqueio (soro de cavalo, 7\%), com 30 minutos de incubação. Após isso, os anticorpos primários foram adicionados (diluição de 1:100 do F4/80 e 1:400 do GR1). As lâminas foram incubadas overnight com os anticorpos primários. No dia seguinte as lâminas foram lavadas e uma solução de $\mathrm{H}_{2} \mathrm{O}_{2}$ foi adicionada por 10 minutos, seguida de nova lavagem. Na sequência, foi adicionado anticorpo secundário (com incubação de 1 hora), seguido de aplicação do complexo avidina/biotina e revelação pelo DAB. Após essas etapas, foi realizada a contra-coloração com hematoxilina. Para

a análise, as lâminas foram observadas em um microscópio de luz (Zeiss, Thornwood, NY, EUA) tendo sido avaliados 25 campos por lâmina, escolhidos 
aleatoriamente, que praticamente cobrirá toda a medular externa dos cortes. A quantificação foi feita baseada no número de células positivas por campo.

\subsection{Determinação da presença de hipóxia}

A presenção de hipóxia foi avaliada através da detecção de pimonidazol, pelo protocolo de Hypoxyprobe (Burligton, MA, EUA), o qual se liga a grupamentos tióis de tecidos ou células que ficaram numa condição de $\mathrm{pO}_{2}$ menor do que $10 \mathrm{mmHg}$. Os tecidos foram processados pela técnica de IHQ, seguindo o mesmo protocolo do item anterior. Já a detecção de hipóxia nas células foi feita por imunofluorescência. Após o protocolo experimental, as células, já cultivadas em lâminas, foram lavadas $2 \mathrm{X}$ com PBS, e foi adicionada uma solução de paraformaldeído $2 \%$. Em seguida, foi feita nova lavagem e adicionou-se uma solução de triton 0,5\%. Após mais uma lavagem, foi adicionada solução de bloqueio (soro de cavalo 7\%) por 30 minutos, seguido de adição do anticorpo primário (diluído 1:100 em PBS), com incubação overnight. No dia seguinte, os cortes foram incubados por 1 hora com o anticorpo secundário, marcado com o fluorórofo TexasRed (Abcam, San Francisco, EUA). Na sequência, adicionou-se o corante de núcleo (Hoechst - Life Technologies, EUA). Em seguida, as lâminas foram analisadas em um microscópio de fluorescência (Zeiss, EUA).

\subsection{Análise de ciclo celular e apoptose por fragmentação nuclear}

As amostras, contendo de $1 \times 10^{5}$ a 2,5 $\times 10^{5}$ células, foram centrifugadas a 240 g por 5 min a $4^{\circ} \mathrm{C}$ e ressuspendido em $300 \mu \mathrm{l}$ de tampão hipotônico HFS contendo 0,1\% de Triton X-100, 0,1\% de citrato de sódio e 50 $\mu \mathrm{g} / \mathrm{ml}$ de iodeto de propídeo (PI). Estas células ficaram por um período mínimo de $1 \mathrm{~h}$ de incubação a $4^{\circ} \mathrm{C}$ antes de serem analisadas por citometria de fluxo num citômetro FACScalibur (BD, EUA). O conteúdo de DNA produziu um perfil gráfico dependente da fase do ciclo celular em que estas se encontravam. Foram considerados eventos apoptóticos os núcleos 
hipodiplóides, que no gráfico aparecem à esquerda do pico G0-G1. Foram analisados, por replicata, 5000 eventos. Foi feito uma janela utilizando-se os parâmetros de tamanho (FSC) e granulosidade (SSC) para a exclusão dos debris.

\subsection{Ensaio de citotoxicidade}

A coloração por cristal violeta foi usada para determinar o número de células sobreviventes nas condições de hipóxia ou normóxia, ( \pm 250 ppm CO). Resumidamente, as células foram lavadas duas vezes com PBS e uma solução de cristal violeta (Sigma-Aldrich, MO, EUA) foi adicionada para corar as células, sendo as placas novamente lavadas com água corrente e deixadas para secar overnight. No dia seguinte, uma solução de ácido acético $10 \%$ foi adicionada a cada poço e a quantidade de células sobreviventes foi medida através da leitura da absorbância dessa solução final a $562 \mathrm{~nm}$.

\subsection{Citometria de fluxo}

Os animais foram sacrificados e os rins foram coletados e colocados em filtros (70-100 $\mu \mathrm{m})$, onde os tecidos renais foram mecanicamente homogeneizados. As células foram então diluídas em 15 mL de RPMI e centrifugadas a $1200 \mathrm{rpm}$ por 10 minutos. Em seguida, essas foram ressuspendidas em solução de DNase (12.5 $\mu \mathrm{g} / \mathrm{mL}) /$ collagenase IV $(0.5 \mathrm{mg} / \mathrm{mL})$ em $7 \mathrm{~mL}$ de RPMI. As células foram então incubadas por 30 minutos a $37^{\circ} \mathrm{C}$ e em seguida foi adicionado SFB $10 \%$, sendo as células centrifugadas a 1200 rpm por 10 minutos. Após centrifugação, o sobrenadante foi descartado e as células ressuspendidas em $2 \mathrm{~mL}$ de PBS. As células foram adicionadas a uma solução de Percoll e o material foi centrifugado a 2600 rpm por 25 minutos para separação de fases. As células foram então separadas na fase de

interesse, novamente sofreram centrifugação, sendo ressuspendidas em tampão FACS. Nós analisamos a população de linfócitos infiltrantes renais pela técnica de 
citometria de fluxo de múltiplas cores. Os anticorpos utilizados para marcação de superfície foram F4/80 PerCP, MIG PE, CD206 FITC, (Biolegend, San Diego, CA, EUA). As amostras foram adquiridas em um aparelho FACSCanto, usando o software FACSDIVA (BD Biosciences, EUA) e em seguida analisadas através do programa FLOWJO (Tree Star, San Carlo, CA, EUA). As voltagens de fluorescência foram determinadas usando células não marcadas. A compensação foi feita utilizando células marcadas com somente um marcador. Foram adquiridos no mínimo 200.000 eventos em um gate de células mononucleares vivas.

\subsection{Análise estatística dos dados}

Os resultados estão expressos como média \pm desvio padrão. Para a comparação entre dois grupos experimentais foi utilizado o teste $t$ de Student e para comparação entre mais de dois grupos experimentais utilizamos o ANOVA e como pós-teste Tukey`s Multiple Comparison Test considerando um p<0,05 como significativo. Software utilizado - Graphpad Prism. 
4 RESULTADOS 
A lesão renal isquêmica é considerada a principal causa de LRA e a busca por novos alvos terapêuticos que venham a atenuar as consequências deletérias desse insulto mostrou que a regulação positiva do sistema da HO-1 pode ser extremamente benéfico. Mais especificamente, o CO vem tendo um papel de destaque, uma vez que suas propriedades anti-inflamatórias têm sido associadas a proteção em inúmeras doenças. Assim, decidimos fazer o modelo de IRI renal e avaliar os mecanismos moleculares que levam à proteção após o tratamento com um indutor da HO-1 ou pela administração direta de CO.

\subsection{Animais submetidos a IRI exibem um perfil transcricional global diferencial}

Sabe-se que uma série de fatores deletérios é desencadeada em consequência à IRI renal, trazendo prejuízo para o órgão lesado e complicações a longo prazo. Entretanto, os mecanismos moleculares importantes para esses processos ainda precisam ser melhores compreendidos. A descoberta das bases moleculares de doenças complexas, como é o caso da LRA, foi facilitado com os avanços da genômica funcional, permitindo uma análise profunda dos resultados gerados [138]. A tecnologia de microarranjos de DNA é indicada para o estudo de assinaturas gênicas, uma vez que oferece a vantagem de analisar milhares de genes simultaneamente. Essa tecnologia, em conjunto com ferramentas de bioinformática pode detectar mudanças em genes previamente desconhecidos que participam de um determinado insulto.

Decidimos então verificar o perfil genômico dos rins de animais submetidos à IRI renal e comparamos com um grupo controle. A princípio, é possível verificar que os rins dos animais submetidos à IRI apresentam uma assinatura gênica bem diferente dos animais controle (Figura 2). Além disso, quando agrupamos por processos biológicos, verificamos uma série de genes diferencialmente expressos no grupo IRI, com destaque para as seguintes categorias: resposta a estímulos protéicos, resposta a proteínas mal empacotadas do retículo endoplasmático, resposta ao 
estresse, resposta inflamatória e apoptose. A presença da rede de processos em círculo na Figura 2B ilustra como estresse, inflamação e apoptose foram modulados juntos, em um nível de RNAm em resposta a um insulto, uma vez que a expressão dos genes contidos nesse módulo mostram alta co-expressão em resposta à IRI. Assim, resolvemos estudar com mais detalhes essas interações na LRA, dando uma atenção especial a inflamação e a ERS, além de avaliarmos como o sistema da HO-1 poderia modular tais processos. 
Figura 2 - Animais submetidos a IRI renal exibem uma assinatura gênica nitidamente diferente de animais controle.

A.

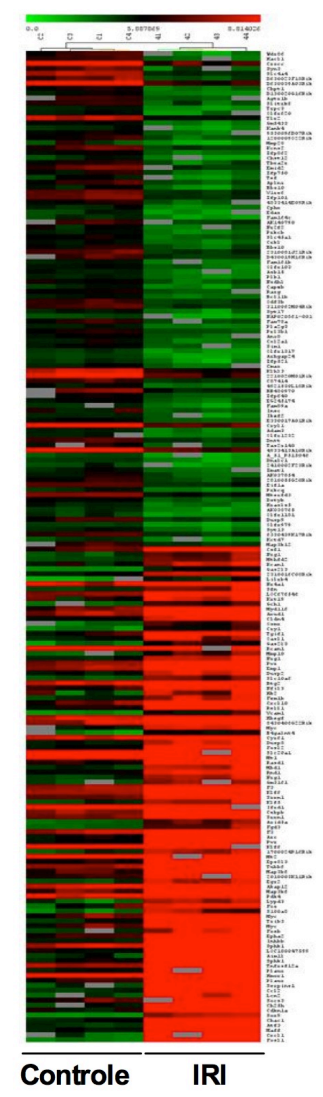

B.

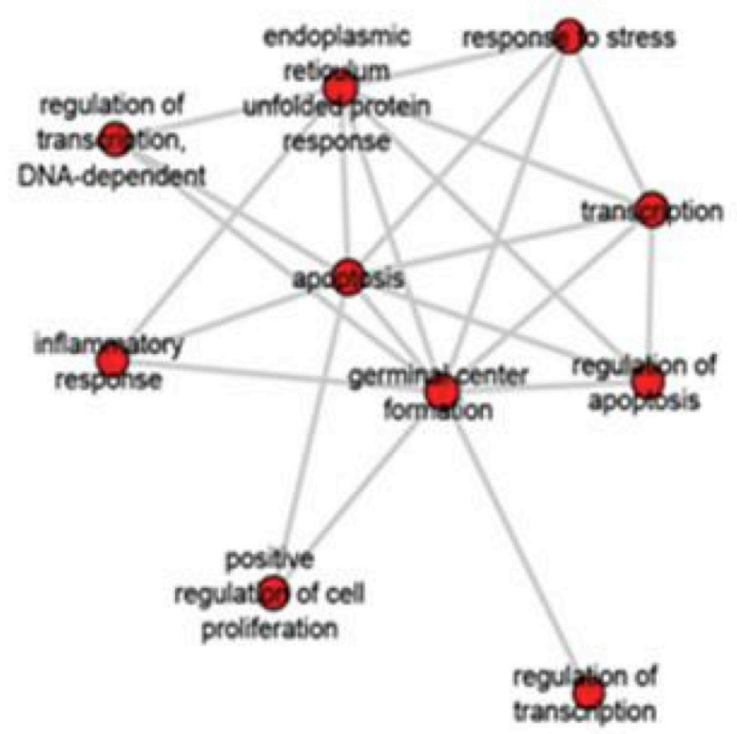

A. Heatmap dos 100 genes regulados negativamente e dos 100 genes regulados positivamente após a IRI renal. B. Mapa de interações transcricionais, observadas no grupo IRI, relacionadas a diferentes processos biológicos.

\subsection{O tratamento com um indutor da HO-1 leva a uma melhora da disfunção renal}

Com a intenção de avaliarmos o papel da HO-1 na IRI renal, realizamos a cirurgia de isquemia e repefusão e sacrificamos os animais em diferentes tempos após a reperfusão, sendo que um grupo foi tratado com o indutor da HO-1, Hemin. Quando comparado com os valores basais (animais controle), verificamos que ao sacrificarmos os animais antes da reperfusão há um aumento dos valores séricos de creatinina e uréia (Figura 3), possivelmente devido ao fato de que como o sistema renal ficou relativamente inoperante durante 45 minutos, houve um acúmulo dessas excretas na circulação. Ao sacrificarmos os animais após algum período de 
reperfusão, verificamos que ocorre, inicialmente, uma leve disfunção renal, que com o passar do tempo se torna mais grave, e atinge seu ápice após 24 horas. Como podemos observar na mesma figura, o tratamento com Hemin foi capaz de proteger funcionalmente o rim, atenuando de maneira marcante essa desregulação do processo de filtração glomerular.

Figura 3 - Tratamento com Hemin atenua a disfunção renal causada pela IRI.

A.

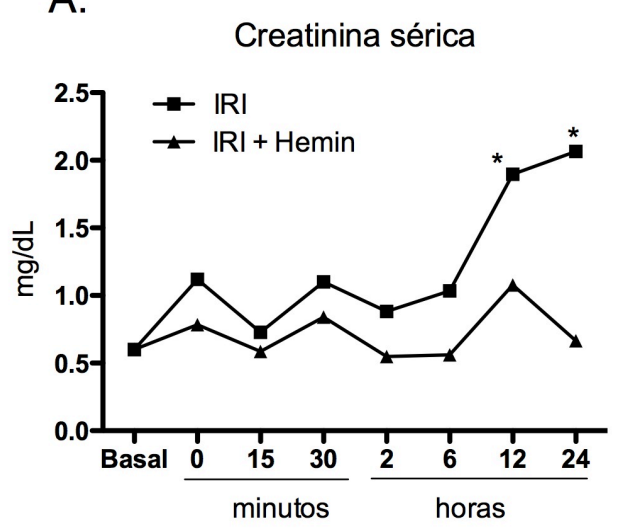

B.

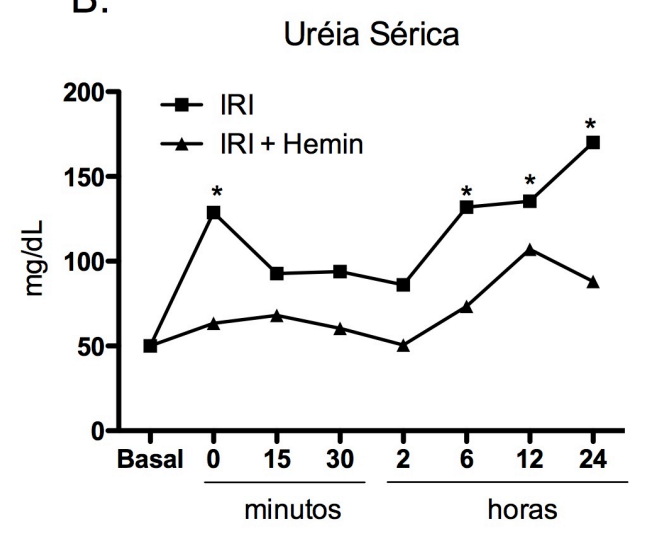

Valores séricos de creatinina (A) e uréia (B), em diferentes tempos pós-reperfusão, de animais submetidos à IRI renal e que foram tratados ou não com Hemin $(25 \mathrm{mg} / \mathrm{Kg})$. * $\mathrm{p}<0,05 \mathrm{vsIRI+Hemin}$.

A fim de analisarmos se essa proteção nos animais tratados foi decorrente do aumento da expressão de HO-1, verificamos a expressão gênica dessa molécula e verificamos que há um aumento significativo nos diversos tempos de sacrifício, com picos no período de 6-12 horas pós-reperfusão. Os animais submetidos apenas à cirurgia de IRI também tiveram uma maior expressão de HO-1 nesses mesmos pontos. Vale ressaltar que em todos pontos observados, a expressão de HO-1 nos animais tratados foi significativamente maior do que a mesma no grupo não tratado (Figura 4, painel A).

Uma vez que a lesão de IRI induz a expressão de TNF- $\alpha$ [139], utilizamos essa citocina como marcador do processo inflamatório. Como observado na Figura 4B, o grupo de animais não tratados apresenta um aumento significativo da expressão 
dessa molécula de forma precoce, 15 minutos após a reperfusão, seguida de uma diminuição dessa e a partir de 6 horas após a reperfusão há um novo aumento. Em contrapartida, o grupo Hemin apresentou uma expressão gênica reduzida de TNF- $\alpha$ em todos os períodos observados, sendo significativamente menor que o grupo IRI. Juntos, esses resultados mostram que o tratamento com Hemin leva a um aumento da expressão da HO-1 e isso confere citoproteção ao órgão que sofreu uma LRA, com menor disfunção renal, e menor inflamação.

Figura 4 - O tratamento com Hemin induz a expressão de HO-1 e inibe o processo inflamatório.

A.

HO-1

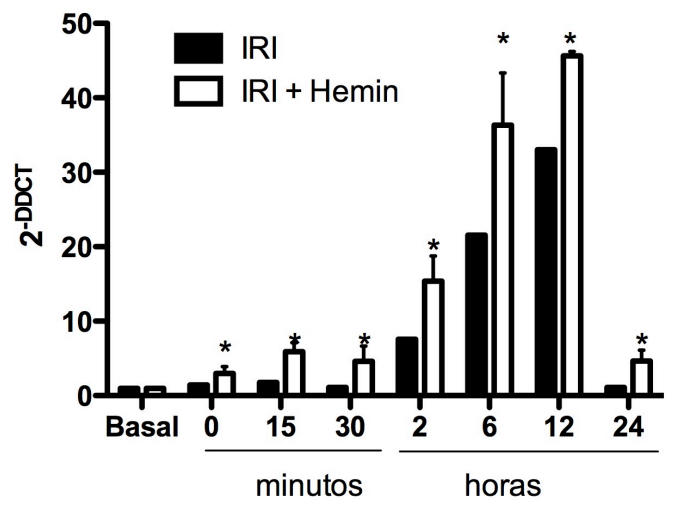

B.

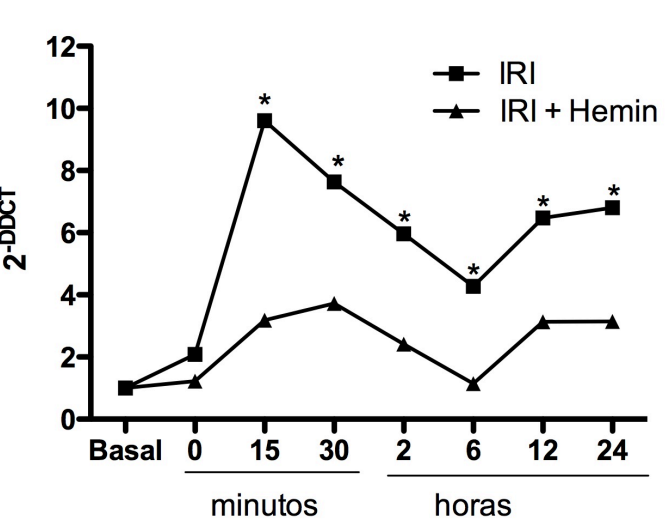

A. Cinética da expressão gênica de HO-1 renal após a IRI em animais tratados ou não com Hemin, na dose de $25 \mathrm{mg} / \mathrm{Kg}$. ${ }^{*} \mathrm{p}<0,05$ vs IRI. Em B, avaliação do processo inflamatório através da expressão e TNF- $\alpha .{ }^{*} \mathrm{p}<0.05$ vs IRI+Hemin. 


\subsection{Modulação do ERS pela indução da HO-1}

Para averiguar a participação do ERS na LRA e sua modulação através do tratamento com Hemin nós avaliamos a expressão gênica de dois marcadores de estresse do retículo, a molécula $\mathrm{BiP}$, da via das UPR, e a molécula CHOP, da via próapoptótica. Ao analisarmos a expressão de transcritos de RNAm para a molécula BiP, pudemos observar pela Figura 4, painel A, que no grupo que não recebeu tratamento há um aumento da expressão dessa molécula até 15 minutos após reperfusão. Em seguida, a expressão apresenta uma pequena redução e se mantém constante até 12 horas após a reoxigenação dos rins, com nova queda 24 horas após a reperfusão. Já no grupo tratado com Hemin, observou-se que tal marcador de ERS encontra-se aumentado num primeiro momento, sendo que na sequência há uma forte redução deste marcador, mantendo-se reduzido e com valores significativamente menores do que o grupo IRI (Figura 5A).

Ao analisarmos a expressão gênica de CHOP, verificamos que nos dois grupos há um aumento de sua amplificação a partir de 15 minutos após a reperfusão e uma queda no período de 24 horas. Porém, no grupo tratado esse aumento é significativamente menor do que no grupo não tratado, sugerindo assim que houve menor indução de vias pró-apoptóticas nesses animais (Figura 5, painel B).

Confirmando esses dados, ao avaliarmos a expressão protéica dessas mesmas moléculas - após 24hs de reperfusão - verificamos um aumento na expressão de BiP nos animais que sofreram a IRI renal, em relação ao grupo controle. Porém, não se observou diferença em relação aos grupos tratado e não-tratado com Hemin. Já em relação ao $\mathrm{CHOP}$, há também um aumento da expressão dessa molécula no grupo IRI, em relação ao controle. Entretanto, no grupo Hemin há uma marcante redução da mesma (Figura 5, painel C). Assim, podemos inferir que, na presença da HO-1, há uma menor ativação do processo de ERS. 
Figura 5 - A IRI renal promove ERS, condição revertida pela indução da HO-1.

A.

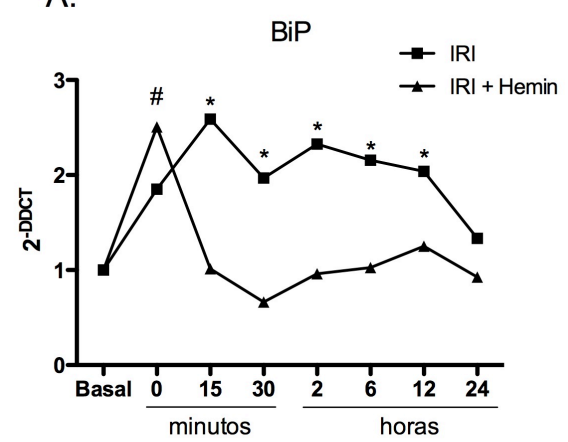

B.

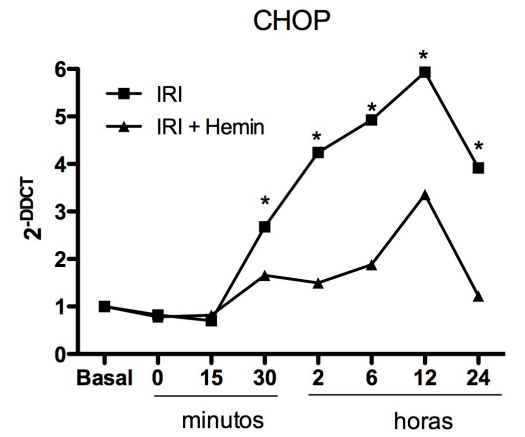

C.

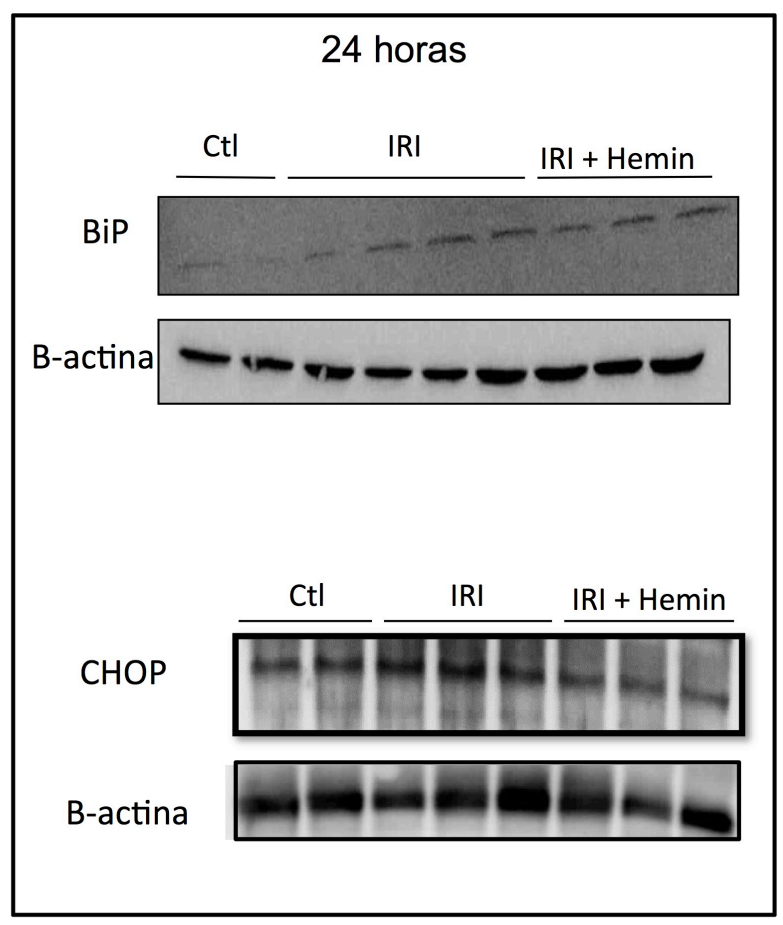

A expressão gênica de BiP (A) e CHOP (B) foi avaliada em diferentes momentos pósreperfusão no tecido renal de animais submetidos à IRI e tratados ou não com Hemin $25 \mathrm{mg} / \mathrm{Kg}$. * p<0,05 vs IRI+Hemin. Em C, análise dos níveis protéicos de BiP e CHOP nos animais sacrificados 24 horas após a reoxigenação renal.

\subsection{Células tubulares renais sofrem ERS frente a um estímulo farmacológico}

Para avaliar os mecanismos pelos quais a HO-1 estaria modulando o processo de ERS, decidimos realizar alguns experimentos in vitro. Inicialmente, resolvemos averiguar se as células tubulares utilizadas por nós seriam reguladas positivamente para HO-1 após o tratamento com Hemin. Como observado na Figura 6, o tratamento com Hemin leva a um aumento dos níveis dessa enzima não só imediatamente após o tratamento, mas mesmo 24 horas após a retirada do estímulo. 
Figura 6 - Aumento da expressão de HO-1 em células tratadas com Hemin.

\section{$\mathrm{HO}-1$}

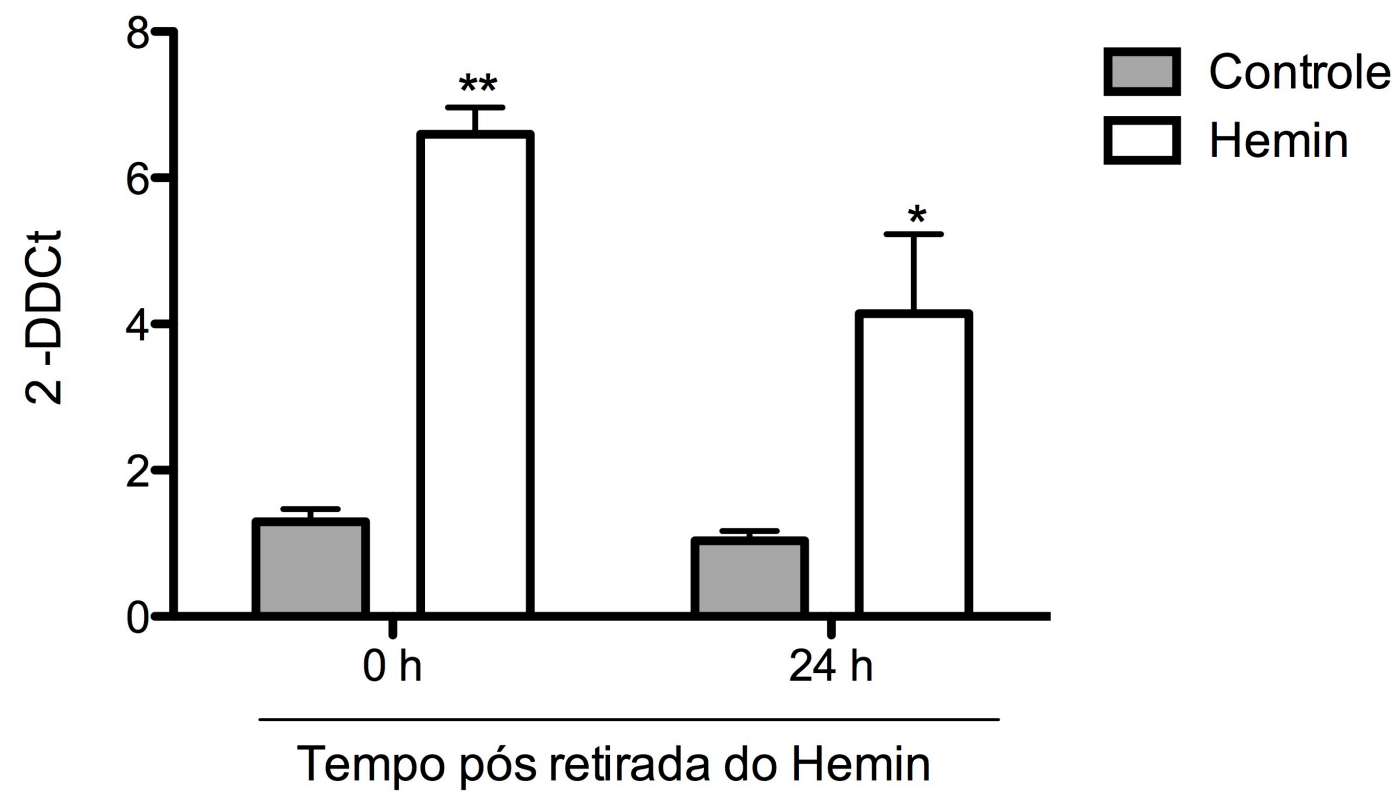

Células tubulares renais, estimuladas com Hemin $10 \mu \mathrm{M}$ por 2 horas exibem um aumento da expressão de HO- 1 , mesmo em momentos tardios após a retirada do estímulo. ${ }^{*} \mathrm{p}<0,05$ vs Controle $\mathrm{e}^{* *} \mathrm{p}<0,005$ vs controle. 
Ainda, para caracterizar o processo de ERS nessas células, decidimos submetêlas a diferentes tratamentos, com drogas sabidamente indutoras de ERS, tapsigargina e tunicamicina. Após 12 horas de estímulo, observamos que ambos os estímulos efetivamente promoveram um destacado aumento da expressão gênica e protéica de BiP, (Figura 7, painéis A e B, respectivamente). Ainda, a regulação positiva dessa via promoveu um maior perfil inflamatório nessas células, com aumento significativo da expressão de TNF- $\alpha$ e IL-6 (Figura 7, painéis D e E). A via pró-apoptótica do ERS também foi induzida nessas células, uma vez que observamos um aumento significativo da expressão gênica e protéica de CHOP (Figura 7, painéis A e C), acompanhado de aumento também significativo da expressão da molécula próapoptótica, Bax (Figura 7, painel F). 
Figura 7 - Indução do ERS em células renais tratadas com tapsigargina ou tunicamicina.

A.

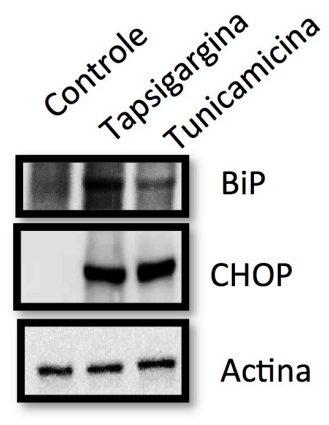

C.

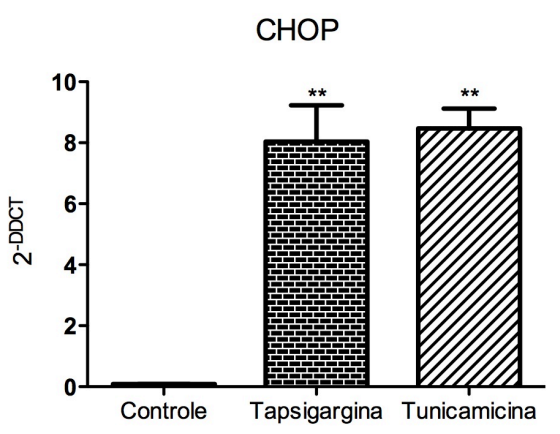

E.

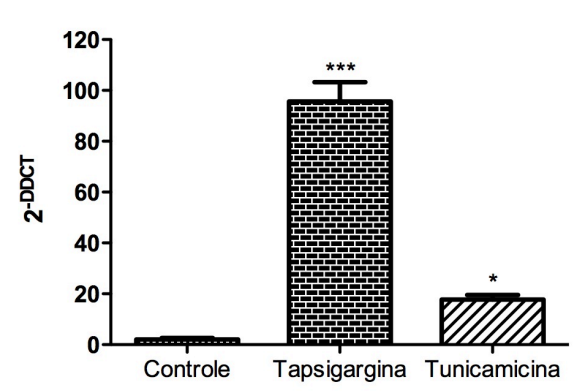

B.

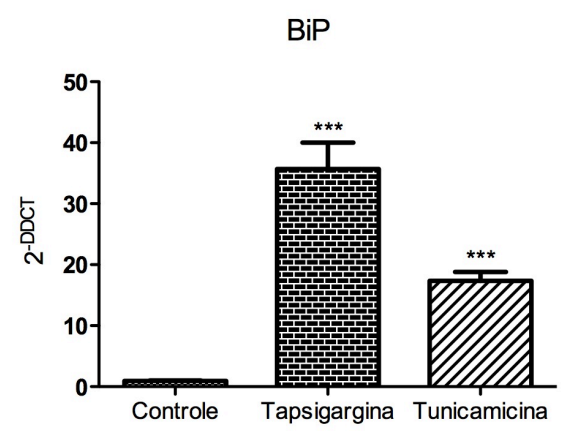

D.

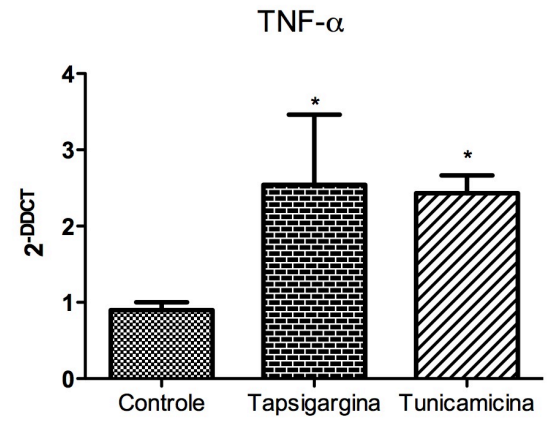

F.

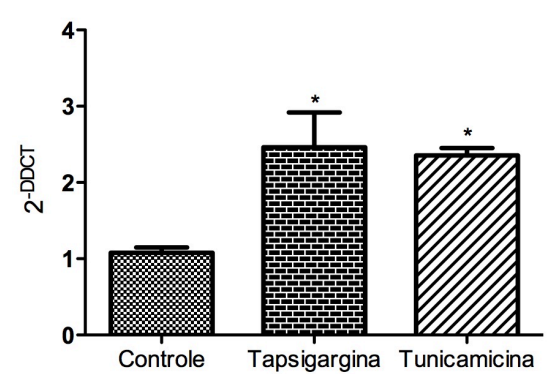

Células epiteliais renais foram tratadas com tapsigargina $(150 \mu \mathrm{M})$ ou tunicamicina (1 $\mathrm{mg} / \mathrm{mL}$ ) por 12 horas e em em seguida foram avaliados os níveis protéicos de BiP e CHOP (painel A) e a expressão gênica de BiP (B), CHOP (C), TNF- $\alpha$ (D), IL-6 (E), e Bax (F). * p<0,05 vs controle; ${ }^{* *} p<0,01$ vs controle; ${ }^{* * *} p<0,001$ vs controle. 
Além disso, a análise do ciclo celular mostrou que tais tratamentos levaram a um aumento significativo de células em apoptose (Figura 8, painéis A e B). Ainda, a ativação do ERS levou a um maior número de células na fase G1 do ciclo celular, indicando um perfil de quiescência celular nos grupos tratados com tapsigargina e tunicamicina (Figura 8C). Por fim, também verificamos que há uma menor viabilidade celular com os tratamentos, sendo que nas células submetidas ao tratamento com tapsigargina essa redução foi mais destacada (Figura 8D). Tais resultados sugerem que as células tubulares renais aumentam a expressão de $\mathrm{HO}-1$ quando tratadas com Hemin e que as mesmas sofrem ERS, com ativação de ambas as vias desse processo, resultando em maior inflamação, apoptose e sustentação da fase G0/G1 do ciclo celular. 
Figura 8 - Ativação do ERS leva a alteração do ciclo celular e aumento do processo de apoptose.

A.
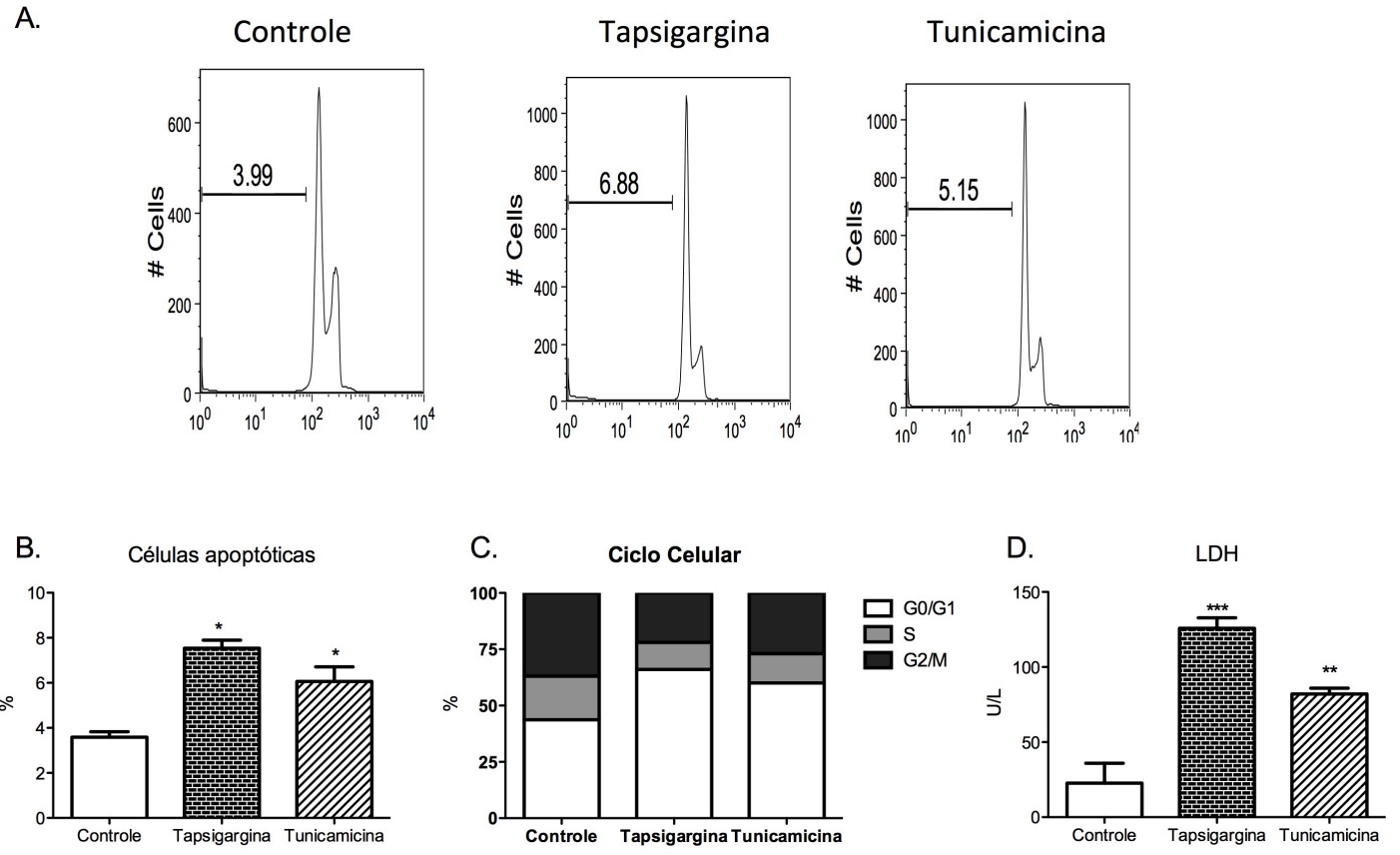

No painel A, avaliação do perfil do ciclo celular em células tratadas com tapsigargina (150 $\mu \mathrm{M})$ ou tunicamicina $(1 \mathrm{mg} / \mathrm{mL})$ por 12 horas. Em B, quantificação da porcentagem de células apoptóticas após tratamento com as drogas descritas anteriormente. Em C, distribuição das fases do ciclo celular. O painel $\mathrm{D}$ indica a dosagem de desidrogenase lática como parâmetro de avaliação de viabilidade celular. ${ }^{*} \mathrm{p}<0.05$ vs controle; ${ }^{* *} \mathrm{p}<0,01$ vs controle; ${ }^{* * *} \mathrm{p}<0,001$ vs controle. 


\subsection{A HO-1 inibe in vitro a indução do ERS causada pela tapsigargina}

Uma vez que mostramos que, após a indução farmacológica de ERS, as células tubulares têm maior sinalização para inflamação e apoptose, decidimos então verificar se a HO-1 seria capaz de modular esses processos. Escolhemos a tapsigargina como droga indutora de ERS e pré-tratamos as células com Hemin para induzir a expressão de $\mathrm{HO}-1$.

Como verificado na Figura 9, o tratamento com tapsigargina reduziu significativamente a viabilidade celular, avaliada pelos níveis de desidrogenase lática (LDH). Já nas células que receberam tapsigargina e que foram tratadas com Hemin, apesar de haver maior morte celular, se compararmos com os grupos controle e Hemin, observamos que houve um aumento da viabilidade celularde aproximadamente $50 \%$ quando comparamos com as células que apenas receberam o indutor de ERS.

Além disso, ao realizarmos uma cinética da expressão de TNF- $\alpha$ durante 12 horas de estímulo com tapsigargina, verificamos que desde momentos iniciais há uma maior presença de transcritos gênicos para essa citocina no grupo que não recebeu Hemin, e que o tratamento com indutor de HO-1 levou a uma atenuação da expressão dessa molécula (Figura 9B). Por fim, decidimos avaliar se o tratamento com Hemin atenuaria o ERS induzido pela tapsigargina. Conforme observado na Figura 9, painéis $\mathrm{C}$ e D, a indução da HO-1 promoveu uma redução significativa dos níveis de BiP e CHOP, durante todo o período avaliado. Juntos, esses dados mostram que, na presença de HO-1, há uma regulação negativa do ERS, com menos inflamação e maior viabilidade celular. 
Figura 9 - Aumento da expressão de HO-1 atenua os efeitos deletérios do tratamento com tapsigargina.

A.

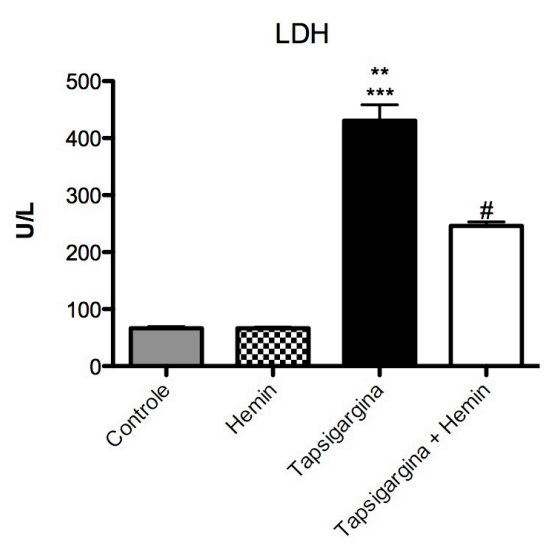

C.

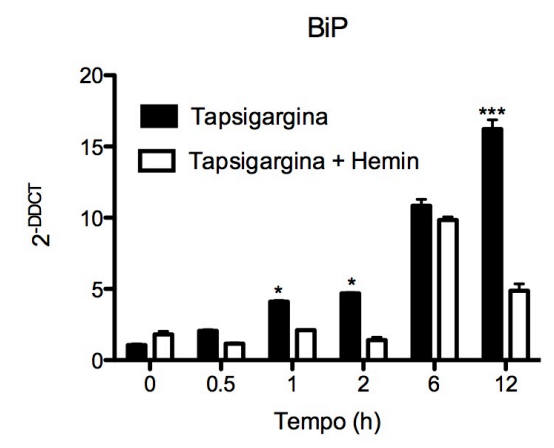

B.

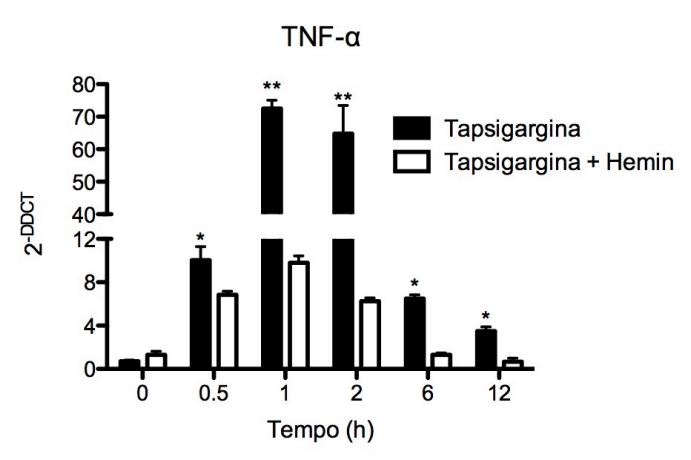

D.

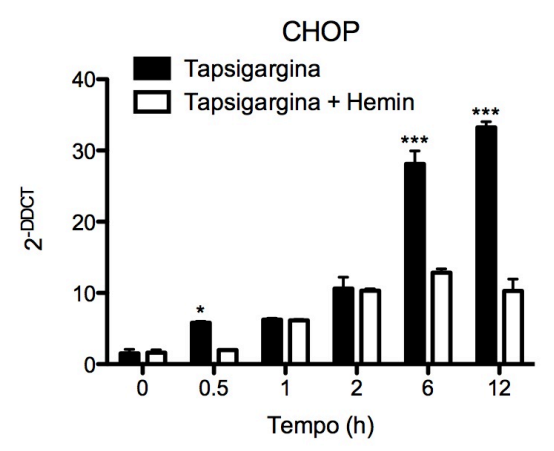

Células renais foram previamente tratadas com Hemin $(10 \mu \mathrm{M})$ por 2 horas, seguido de tratamento com tapsigargina $(150 \mu \mathrm{M})$ durante os períodos indicados. Em A, avaliação da viabilidade celular após 12 horas de estímulo com tapsigargina ${ }^{* *} \mathrm{p}<0,001$ vs controle e Hemin; ${ }^{* *} \mathrm{p}<0,01$ vsTapsigargina+Hemin; \# $\mathrm{p}<0,001$ vs Controle e Hemin. Os painéis B, C e $\mathrm{D}$ indicam a expressam dos níveis de RNAm de TNF- $\alpha$, BiP e CHOP, respectivamente. * $\mathrm{p}<0,05$ vs Tapsigargina+Hemin, ** $\mathrm{p}<0,01$ vs Tapsigargina+Hemin; *** $\mathrm{p}<0,001$ vs Tapsigargina+Hemin. 


\subsection{A deprivação de glicose e oxigênio são fatores agravantes da injúria celular renal}

Com a idéia de simular o modelo in vivo de lesão renal isquêmica para melhor estudar o processo de ERS, e levando-se em conta o trabalho de Fougeray e colaboradores [140], o qual indica que o estresse metabólico (no caso, falta de glicose) é mais importante para a ativação de ERS do que o estresse isquêmico, resolvemos utilizar um modelo in vitro com o protocolo OGD (do inglês oxygen-glucose deprived). Dessa forma, foi adicionado às células um meio sem glicose e estas foram, na sequência, submetidas à hipóxia.

A Figura 10, em seu painel A, mostra-nos que após o período de hipóxia, as células submetidas ao OGD apresentam um aumento de HIF-1 $\alpha$, sugerindo que realmente as células entraram em hipóxia. Ao avaliarmos a viabilidade celular, observamos que após o estímulo com OGD há um aumento da morte celular, fenômeno que está significativamente reduzido nas células que foram previamente tratadas com Hemin (Figura 10B). Além disso, um bom marcador de lesão renal, a molécula KIM-1, mostrou-se significativamente aumentada após o OGD, fato revertido na presença da HO-1 (Figura 10C). Como consequência do tratamento com Hemin, há um aumento da expressão de HO-1 e subsequente aumento da molécula imunorreguladora PPAR- $\gamma$ (Figura 11, painéis A e B). De maneira interessante, os grupos que receberam Hemin apresentaram um aumento (moderado, porém nãosignificativo) de ROS de origem mitocondrial, quando comparados aos grupos não tratados (Figura 11C). 
Figura 10 - Tratamento com Hemin protege as células renais submetidas a falta de glicose e oxigênio.

A.

HIF-1 $\alpha$

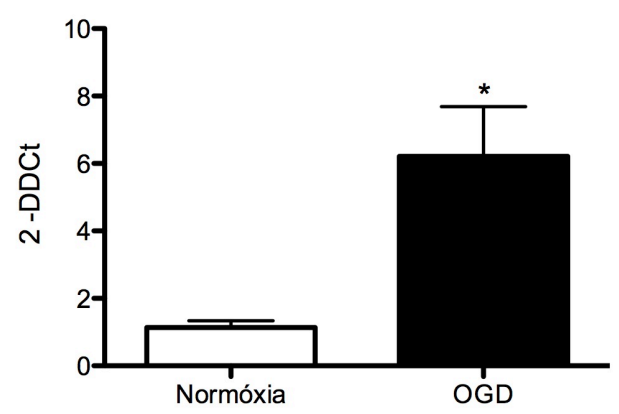

B.

LDH

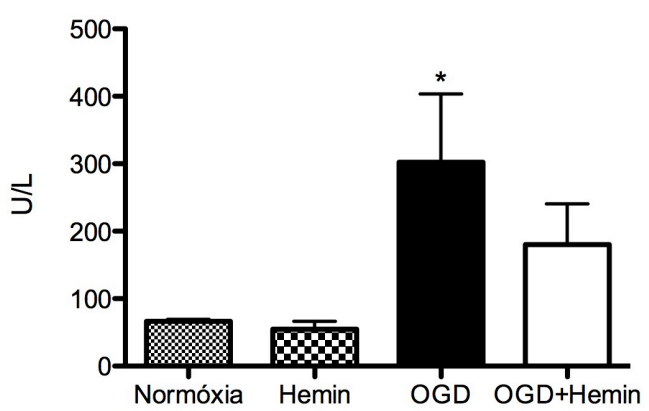

C.

KIM-1

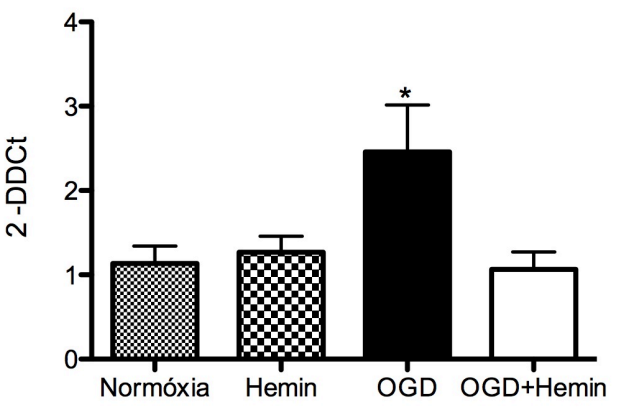

Após o tratamento com Hemin $(10 \mu \mathrm{M})$ por 2 horas, as células renais foram submetidas ao protocolo OGD. Em A, avaliação dos níveis transcricionais de HIF-1 $\alpha$. Em B, dosagem de desidrogenase lática para avaliacão de viabilidade celular. No painel C, mensuração da expressão gênica de KIM-1. * $\mathrm{p}<0,05$ vs demais grupos. 
Figura 11 - Avaliação da sinalização citoprotetora após o tratamento com Hemin, no modelo de OGD.
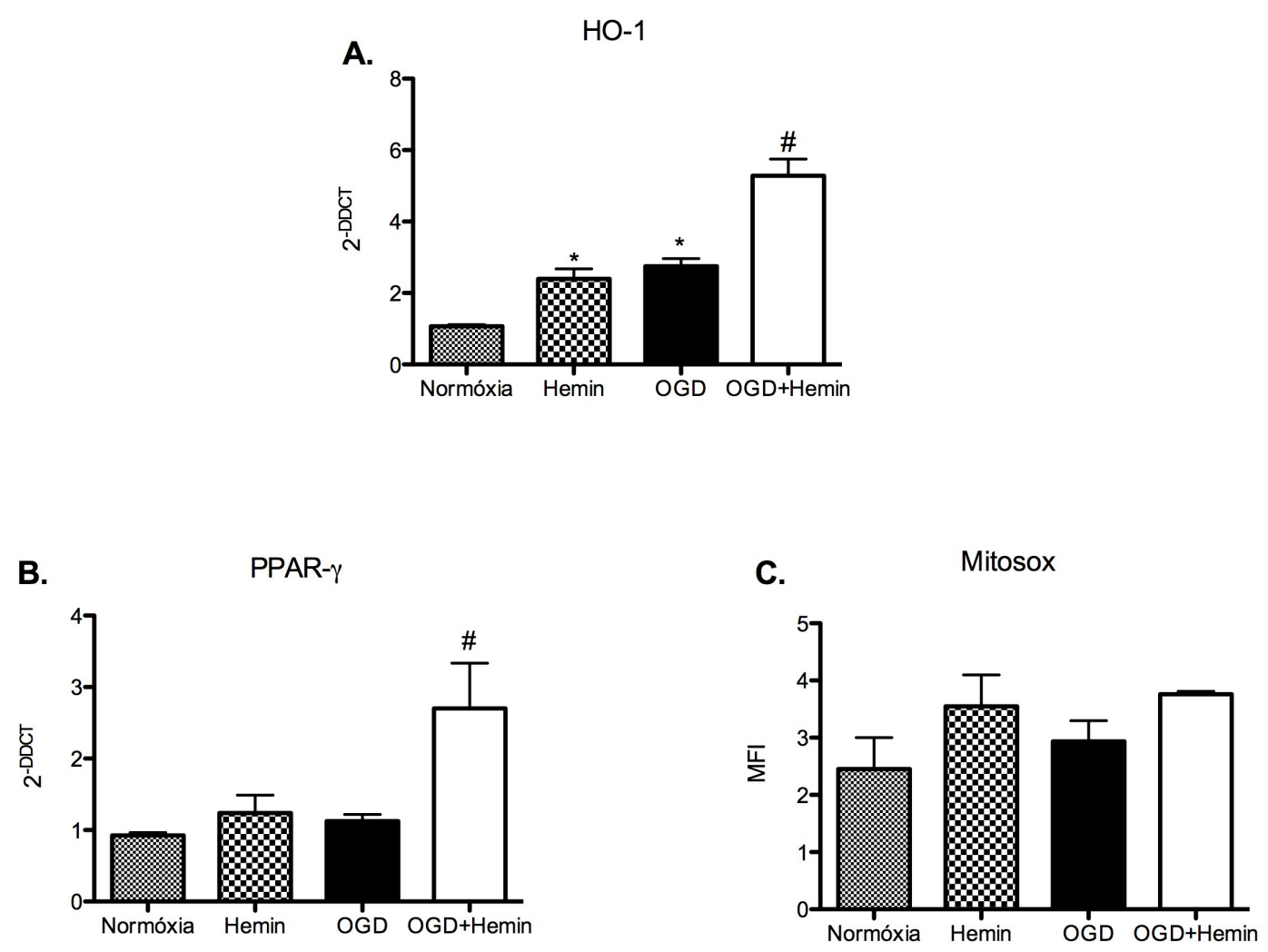

Ao final do protocolo de OGD, as células dos diferentes grupos acima representados foram coletadas e avaliadas para expressão de A) HO-1 e B) PPAR- $\gamma$. No painel C, avaliação da produção de ROS de origem mitocondrial. * $\mathrm{p}<0,05$ vsnormóxia; \# $\mathrm{p}<0,05$ vs demais grupos.

Além disso, as células submetidas ao OGD exibiram uma maior expressão e produção das moléculas pró-inflamatórias TNF- $\alpha$ e IL-6. Em contrapartida, o grupo que recebeu pré-tratamento com Hemin mostrou uma atenuação do processo inflamatório, com concomitante aumento da produção da citocina anti-inflamatória IL-10 (Figura 12). Juntos, esses dados indicam que, no modelo de OGD, o aumento da disponibilidade $\mathrm{HO}-1$ gera um perfil anti-inflamatório e citoprotetor, com consequente aumento da viabilidade celular. 
Figura 12 - O aumento de HO-1 atenua o processo inflamatório causado pelo OGD.

A.

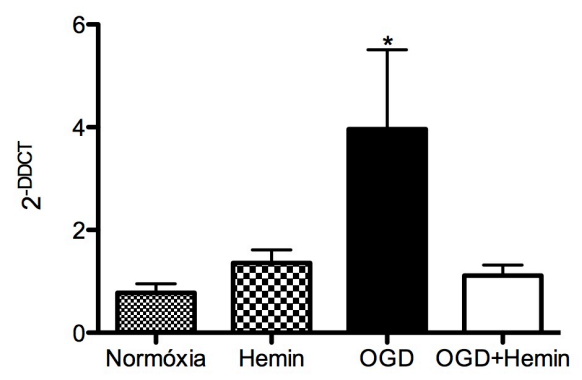

C.

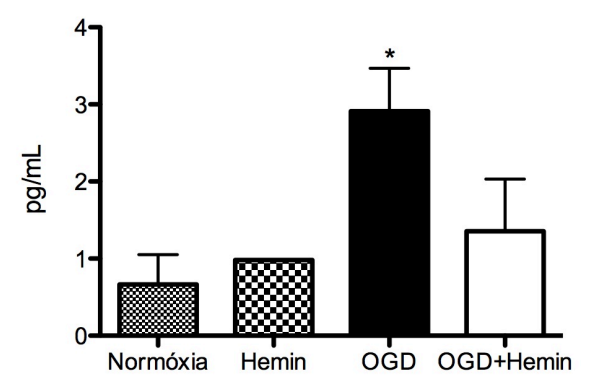

B.

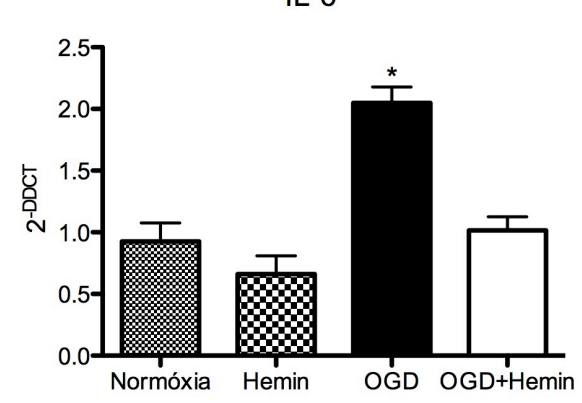

D.

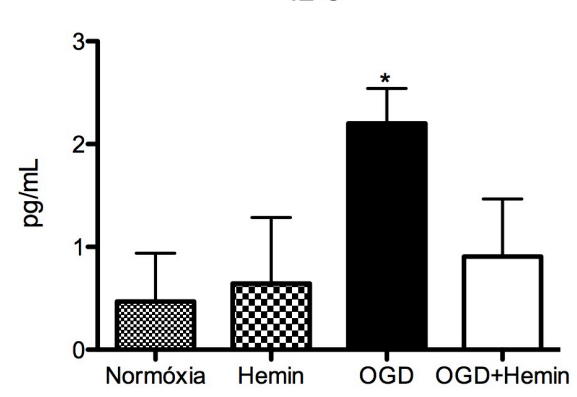

E.

IL-10

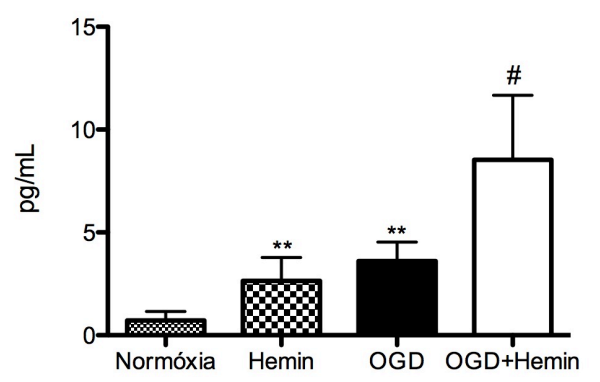

Células renais foram submetidas ao modelo de OGD e um grupo foi previamente tratado com Hemin $(10 \mu \mathrm{M}$, por 2 horas).Após o término do protocolo experimental, as células foram avaliadas para expressão (painéis A e B) e produção (painéis C-E) das citocinas indicadas. * $\mathrm{p}<0,05$ vs demais grupos; ${ }^{* *} \mathrm{P}<0,05$ vs Normóxia; \# $\mathrm{p}<0,01$ vs demais grupos. 


\subsection{O aumento da HO-1 atenua o ERS subsequente ao estímulo OGD}

Uma vez que observamos uma redução da inflamação e da morte celular após o tratamento com Hemin, no modelo de OGD, decidimos verificar se tais condições se traduziriam numa menor ativação do ERS. Como observado na Figura 13, o estímulo com OGD aumentou significativamente as expressões gênicas de $\mathrm{BiP}$ e CHOP, sendo que o pré-tratamento com Hemin promoveu uma diminuição das mesmas. Ainda, a indução da HO-1 levou a uma redução dos níveis da molécula próapoptótica Bax (Figura 13, painel C). Além disso, os níveis protéicos de moléculas marcadoras de ERS - BiP e p-eif $2 \alpha$ - estavam mais expressos no grupo OGD, em relação ao grupo OGD+Hemin. Curiosamente, os níveis de p-eif2 $\alpha$ estavam marcadamente elevados no grupo que recebeu Hemin e cujas amostras foram coletadas sem reoxigenação (Figura 14). 
Figura 13 - HO-1 leva a uma menor ativação do ERS no modelo de OGD

A.

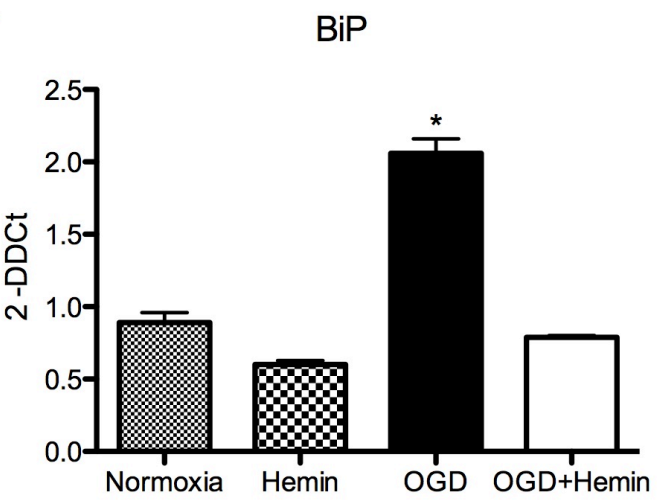

B.

CHOP

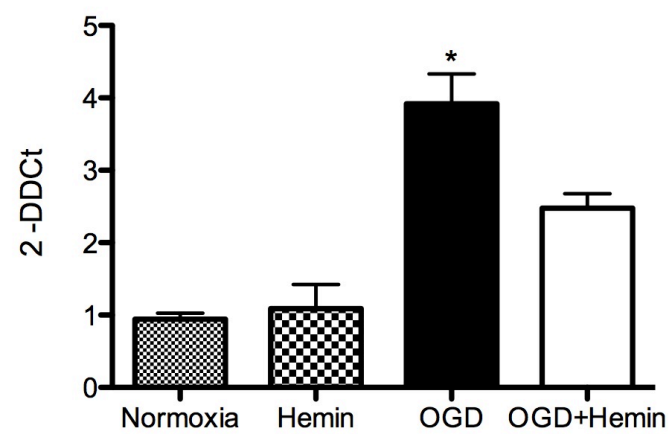

C.

Bax

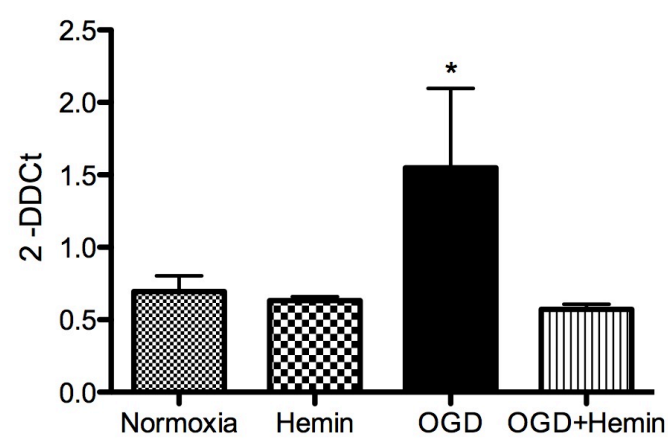

Células renais foram submetidas ao modelo de OGD e um grupo foi previamente tratado com Hemin (10 $\mu \mathrm{M}$, por 2 horas). O ERS foi avaliado através das expressões de BiP (A) e CHOP (B). Em C, quantificação da expressão de RNAm de Bax. ${ }^{*} p<0,05$ vs demais grupos. 
Figura 14 - Avaliação dos níveis protéicos de marcadores de ERS.

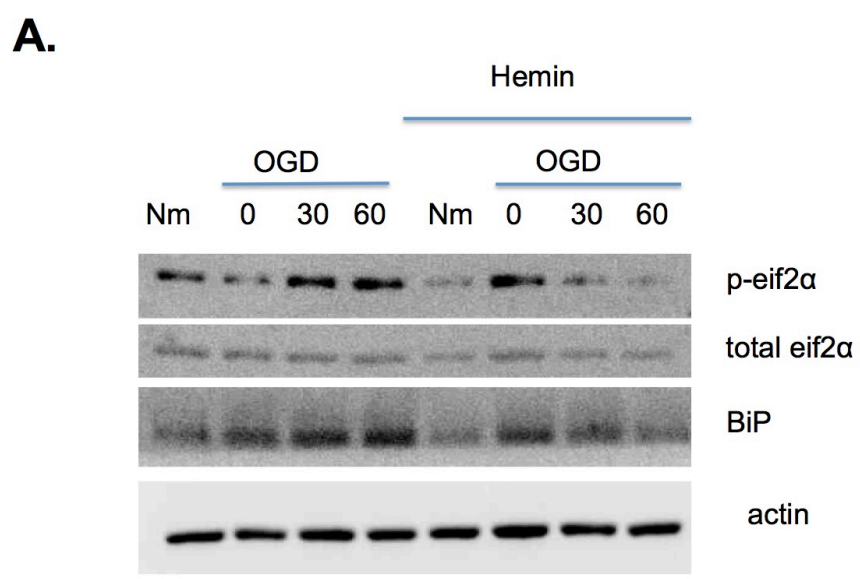

B.

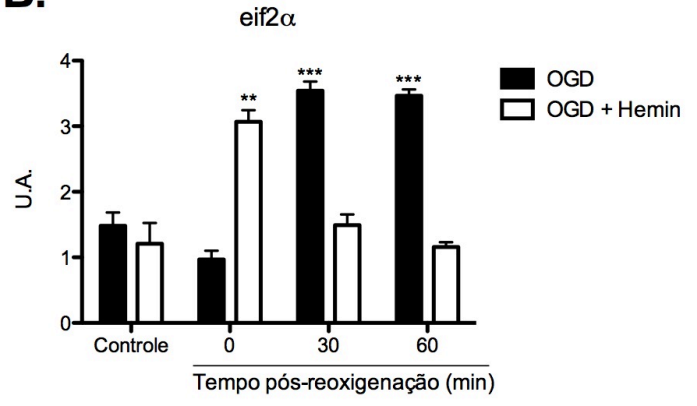

C.

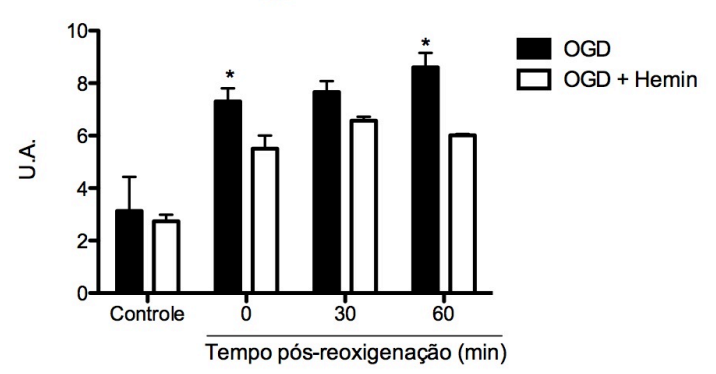

Células renais foram colocadas em hipóxia, pelo protocolo de OGD, e foram coletadas em diferentes tempos após a reoxigenação. $\mathrm{O}$ grupo Hemin recebeu essa droga previamente à hipóxia, na concentração de $10 \mu \mathrm{M}$, por 2 horas. Em A, imagem representativa da expressão protéica das moléculas indicadas, de 3 experimentos independentes. Em B e C, quantificação das expressões de eif $2 \alpha$ e BiP, após normatização. ${ }^{*} \mathrm{p}<0,05$ vs OGD+Hemin; ${ }^{* *} \mathrm{p}<0,01$ vs OGD; ${ }^{* * *} p<0,01$ vs OGD+Hemin.

Assim, esses dados indicam que o tratamento com Hemin influencia diretamente na regulação das vias de ERS, gerando um perfil mais favorável a sobrevida celular. 


\subsection{A proteção observada pela indução de HO-1 é mediada pela AKT e p38 MAPK}

Sabe-se que a regulação transcricional da HO-1 é dependente de uma série de fatores, dentre os quais podemos citar AKT e p38. A fim de verificar se tais moléculas estariam envolvidas na proteção mediada pela HO-1, decidimos avaliar a expressão protéica das mesmas nas células submetidas ao OGD e tratadas ou não com Hemin. Como observado na Figura 15, o tratamento com Hemin levou a um aumento significativo da AKT nos seus dois possíveis sítios de fosforilação. Vale ressaltar que esse aumento ocorreu apenas nos momentos pós-reoxigenação. De forma ainda mais marcante, os níveis de p38 fosforilado estavam significativamente aumentados nas células tratadas com o indutor da HO-1, em todos os tempos avaliados (Figura 16). Portanto, com base nesses dados, podemos inferir que o mecanismo de regulação da HO-1 seria mediado pela AKT e p38, com ênfase para essa última molécula. 
Figura 15 - Ativação de AKT após tratamento com Hemin.

A.

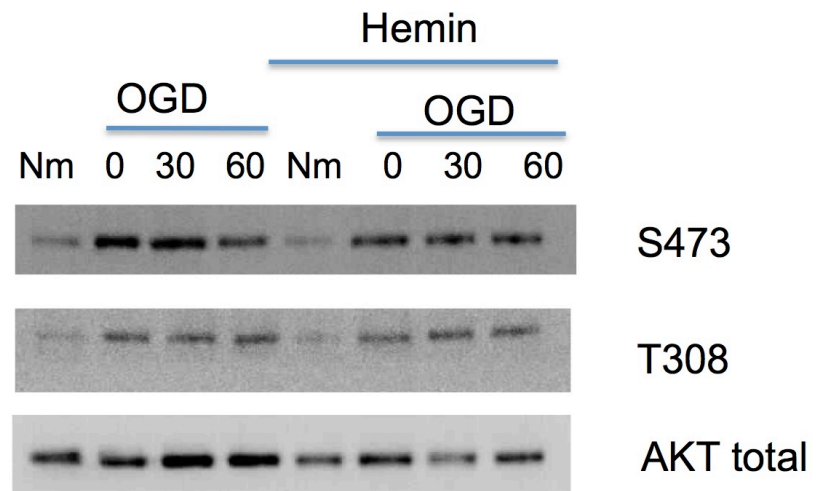

B.

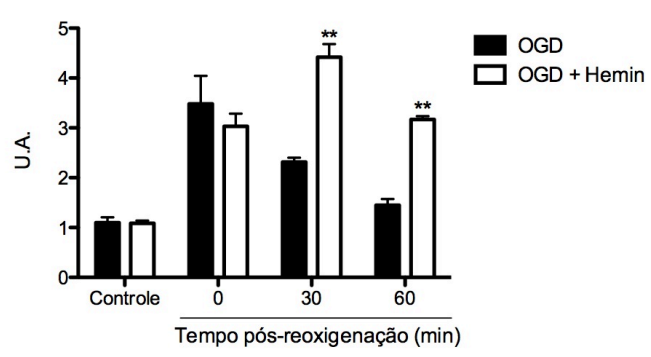

C. $\quad$ AKT T308

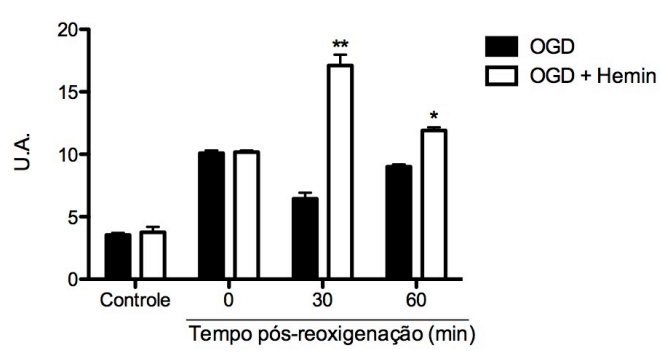

Células renais foram colocadas em hipóxia, pelo protocolo de OGD, e foram coletadas em diferentes tempos após a reoxigenação. O grupo Hemin recebeu essa droga previamente à hipóxia, na concentração de $10 \mu \mathrm{M}$, por 2 horas. Em A, imagem representativa da expressão protéica de AKT S473, AKT T308 e AKT total. Em B e C, quantificação das expressões das protéinas indicadas, após normatização. Foram realizados 3 experimentos independentes utilizando os mesmos grupos para obtenção das amostras. ${ }^{*} \mathrm{p}<0,05$ vs OGD; ${ }^{* *} \mathrm{p}<0,01$ vs OGD. 
Figura 16 - p38 exibe uma indução marcante após tratamento com Hemin.

A.

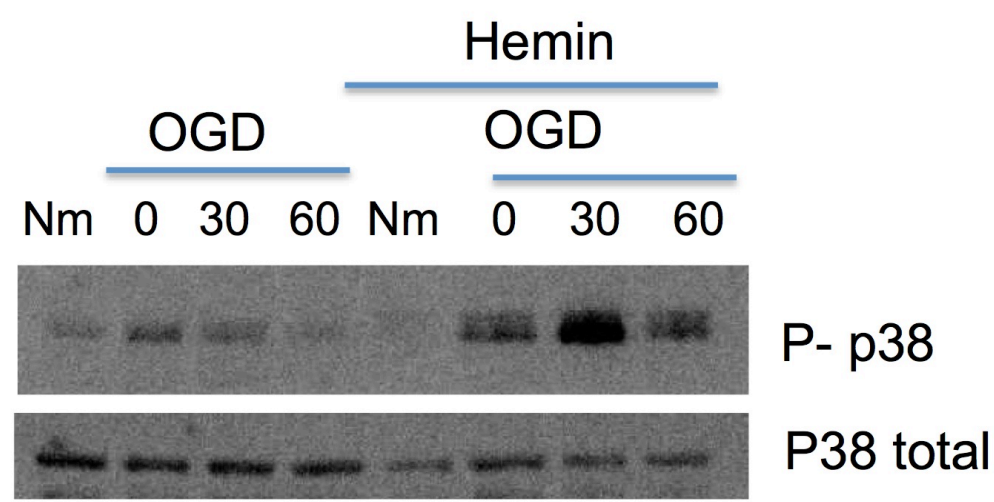

B.

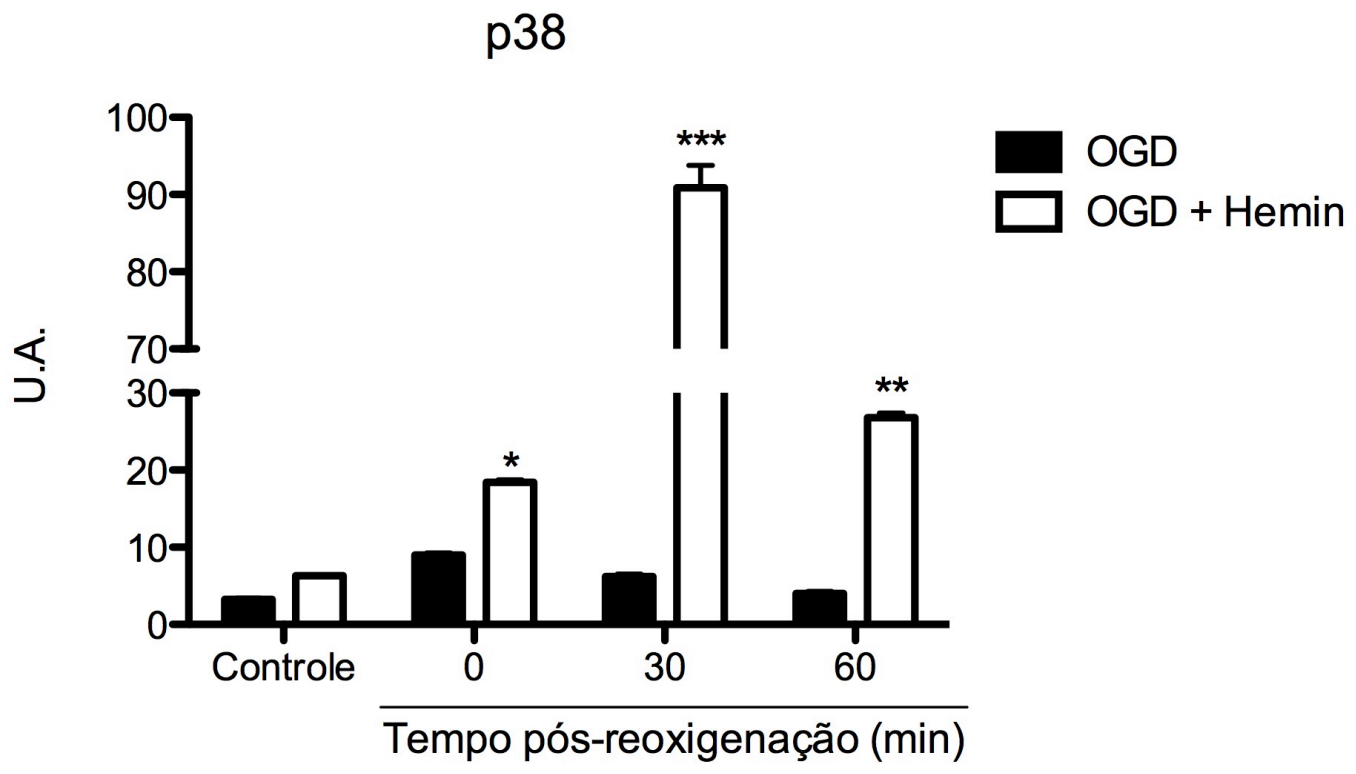

Células renais foram colocadas em hipóxia, pelo protocolo de OGD, e foram coletadas em diferentes tempos após a reoxigenação. Os grupos Hemin recebeu essa droga previamente à hipóxia, na concentração de $10 \mu \mathrm{M}$, por 2 horas. Em A, imagem representativa da expressão protéica de p38, nas suas formas fosforilada e total. Em B quantificação da expressão de p38 após normatização. Os dados são representativos de 3 experimentos independentes. ${ }^{*} \mathrm{p}<0,05$ vs OGD; ${ }^{* *} \mathrm{p}<0,01$ vs OGD; ${ }^{* * *} \mathrm{p}<0,001$ vs OGD. 


\subsection{A inibição da p38 leva à perda da proteção conferida pelo tratamento com Hemin}

Dos dois sinalizadores moleculares da regulação da $\mathrm{HO}-1$ previamente descritos, a p38 parece exercer um efeito bem mais importante no nosso modelo experimental. Baseado nisso, decidimos tratar as células com uma droga inibidora de p38, o SP203580. Conforme pode ser visto na Figura 17, o tratamento com SP203580 promoveu uma reversão da proteção conferida pelo tratamento com Hemin, com redução da viabilidade celular, menor expressão de HO-1 e PPAR- $\gamma$ e consequente aumento da expressão de KIM-1.

Além disso, a inibição dessa MAPK levou a um aumento dos processos inflamatório (Figura 18, painéis A e B) e de ERS (Figura 18, painéis C e D). É interessante salientar que essa diferença entre os grupos que receberam ou não SP203580 somente se mostrou significativa para os grupos tratados com Hemin, já que a expressão de p38 não foi tão marcante nas células que somente foram submetidas ao OGD. Juntos, esses resultados confirmam a importância da p38 para a expressão da HO-1 e consequente proteção ao insulto celular. 
Figura 17 - Inibição da p38 gera uma redução da expressão de HO-1 e consequente perda do perfil citoprotetor do tratamento com Hemin.

A.

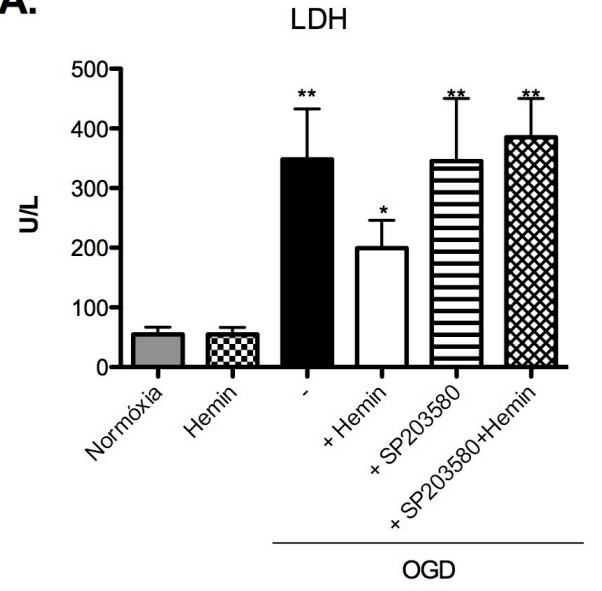

C.

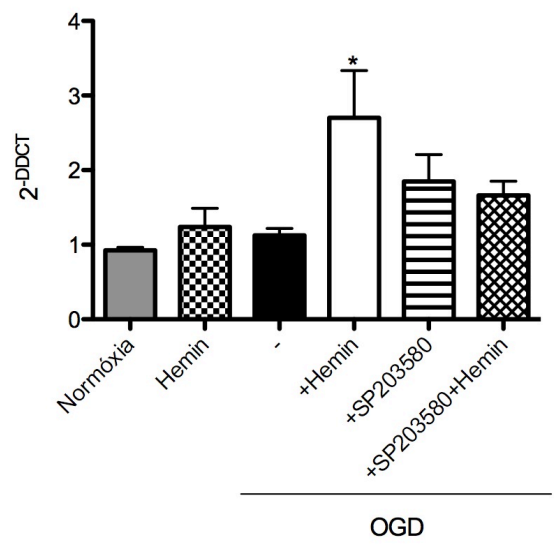

B.

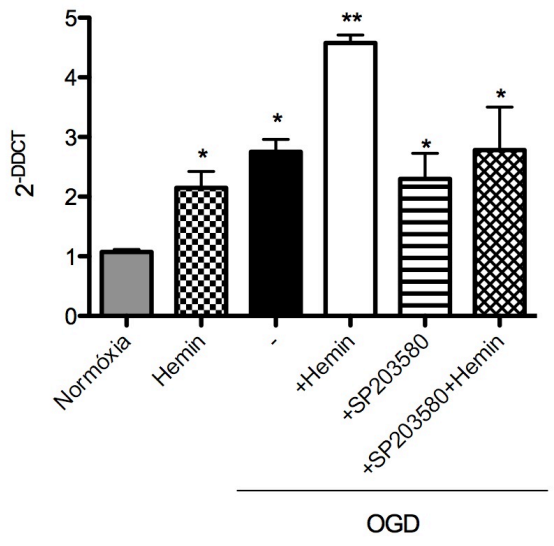

D.

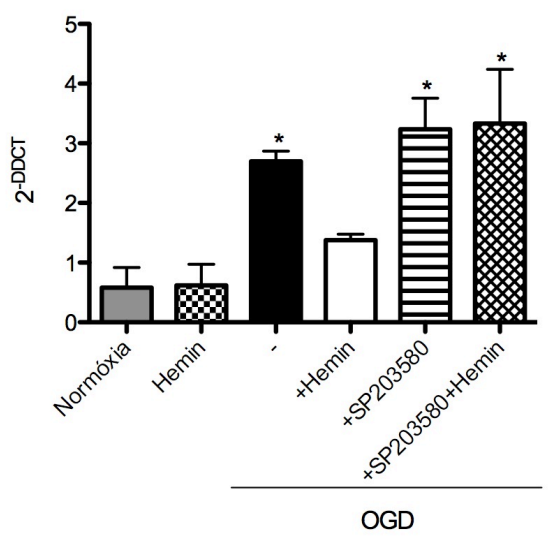

Células renais foram colocadas em hipóxia, pelo protocolo de OGD, e foram coletadas 1 hora após a reoxigenação. Os grupos que receberam Hemin foram tratados previamente à hipóxia, na concentração de $10 \mu \mathrm{M}$, por 2 horas. O inibidor da p38 (SP203580) foi adicionado à cultura, na concentração de $10 \mu \mathrm{M}, 1$ hora antes do estímulo com OGD, sendo mantido até o final do experimento. Em A, avaliação da viabilidade celular pela dosagem de LDH. ${ }^{*} \mathrm{p}<0,05$ vs Normóxia e Hemin; ${ }^{* *} \mathrm{p}<0,01$ vs Normóxia, Hemin e OGD+Hemin. Em B, análise da expressão de HO-1. * $\mathrm{p}<0,05$ vs Normóxia; ${ }^{* *} \mathrm{p}<0,01$ vs demais grupos. Já os níveis de RNAm de PPAR- $\gamma$ e KIM-1 podem ser vistos nos painéis $C$ e $D$, respectivamente. ${ }^{*} p<0,05$ vs demais grupos. Os dados são representativos de 3 experimentos independentes. 
Figura 18 - Perda da ação anti-inflamatória e de inibição do ERS via HO-1 após bloqueio farmacológico da p38.

A.

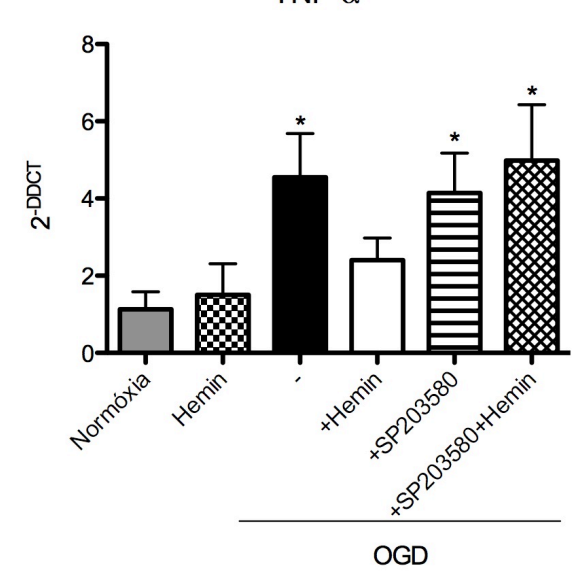

C.

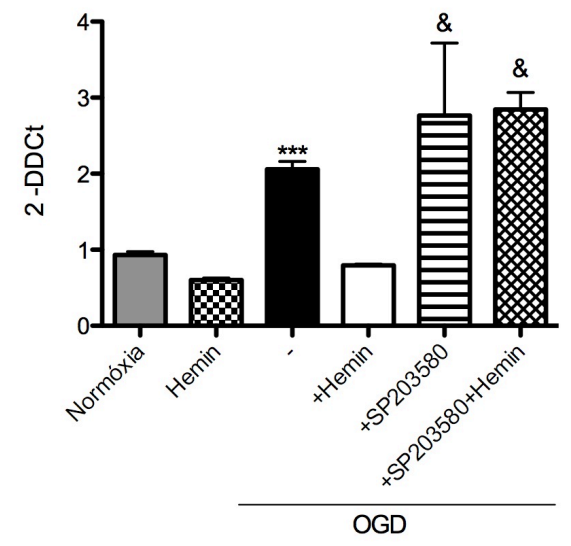

B.

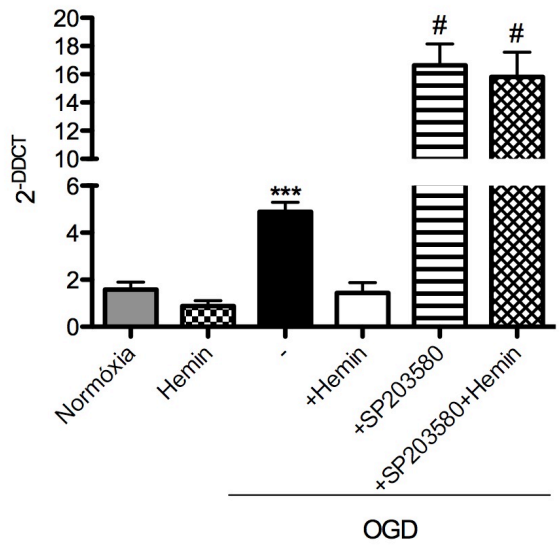

D.

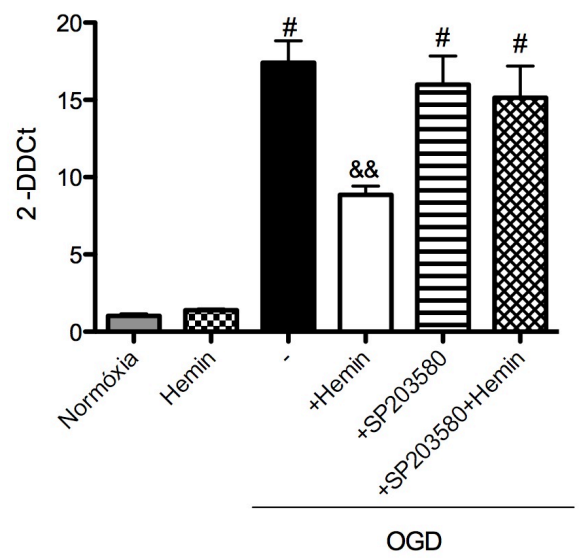

Células renais foram colocadas em hipóxia, pelo protocolo de OGD, e foram coletadas 1 hora após a reoxigenação. Os grupos que receberam Hemin foram tratados previamente à hipóxia, na concentração de $10 \mu \mathrm{M}$, por 2 horas. O inibidor da p38 (SP203580 - 10 $\mu \mathrm{M})$ foi adicionado à cultura 1 hora antes do estímulo com OGD, sendo mantido até o final do experimento. Os níveis transcricionais de TNF- $\alpha$ e IL-6 são exibidos nos painéis A e B, respectivamente. Já os marcadores de ERS, $\mathrm{BiP}$ e CHOP, estão indicados nos painéis $\mathrm{C}$ e $\mathrm{D}$, respectivamente. Os dados são representativos de 3 experimentos independentes. ${ }^{*} p<0,05$ vs demais grupos; ${ }^{* * *} \mathrm{p}<0,01$ vs Normóxia, Hemin e OGD+Hemin; \# $\mathrm{p}<0,001$ vs demais grupos; $\& \mathrm{p}<0,01$ vs demais grupos; \&\& $\mathrm{p}<0,05$ vs Normóxia e Hemin. 


\subsection{Tratamento com CORM e atenuação do ERS}

Com o intuito de utilizarmos outra ferramenta terapêutica e avaliar seu papel na lesão de IRI, bem como sua capacidade em modular o estresse do retículo endoplasmático, resolvemos tratar os animais com CORM. Assim, ao invés de aumentarmos a expressão da HO-1, estaríamos fornecendo diretamente um de seus subprodutos, o CO. Conforme verificado na Figura 19, o tratamento com CORM levou a uma atenuação dos marcadores de ERS, BiP e CHOP, em todos os tempos observados.

Figura 19 - O tratamento com CORM reduz a expressão de marcadores de ERS, no modelo in vivo de IRI renal.

A.

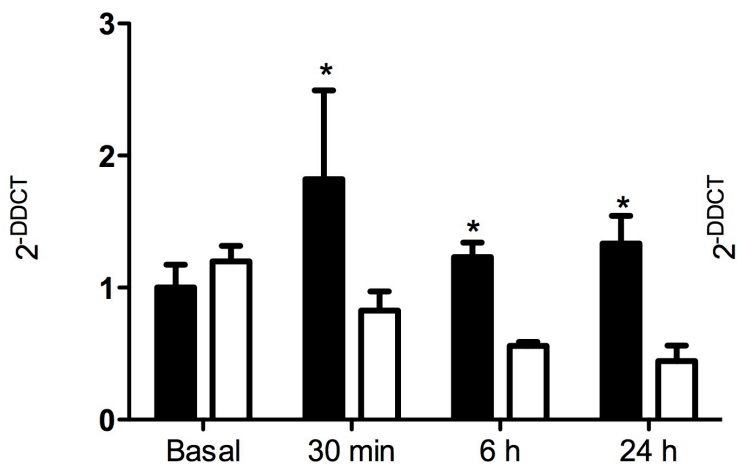

B.

CHOP

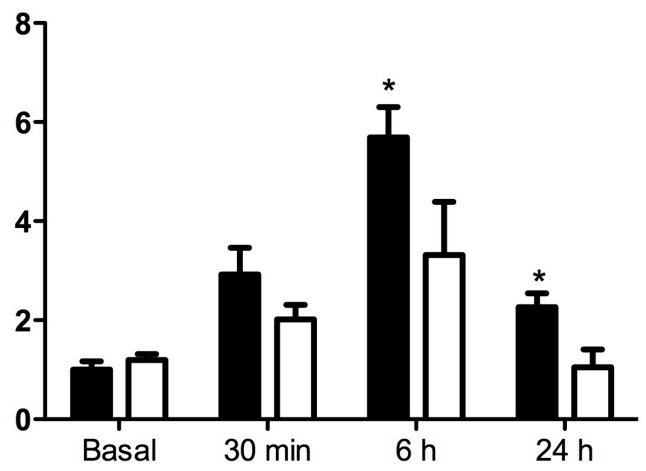

ШRI $\square \mathrm{IRI}+\mathrm{CORM}$

Análise da expressão gênica de (A) BiP e (B) CHOP de animais submetidos a IRI renal e que foram tratados ou não com CORM e sacrificados após $30 \mathrm{~min}$, 6h e 24h após a reperfusão. * $\mathrm{p}<0.05$ vs IRI+CORM.

Além disso, o tratamento com CORM foi capaz de modular as células infiltrantes do sistema imune no tecido renal, uma vez que promoveu uma mudança do perfil de macrófago, do subtipo M1 (identificado pelo marcador de superfície MIG) para o subtipo M2 (identificado por CD206) (Figura 20, painéis A e B, respectivamente). Como consequência, houve diminuição do processo inflamatório, 
conforme avaliado pela expressão gênica de TNF- $\alpha$ (Figura 20, painel C). Todos esses fatores em conjunto acabaram contribuindo para uma melhora funcional do órgão lesado, com menores valores de uréia e creatinina séricas no seu pico de lesão (Figura 21). Juntos, esses resultados nos mostram que o tratamento com um dos subprodutos da HO-1 também promove um bom efeito terapêutico na IRI renal, com redução do ERS, inflamação, menor ativação de fagócitos e melhora da função renal. 
Figura 20 - O CORM promove mudança do perfil de macrófagos infiltrantes.

A.

F $4 / 80+$ MIG+

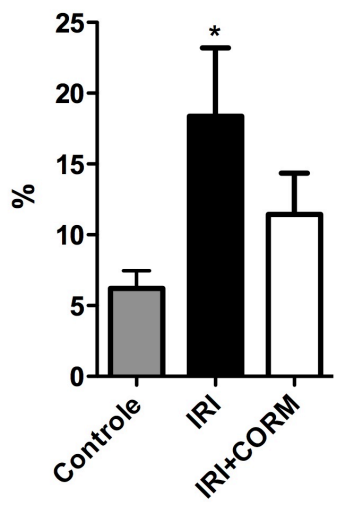

B.<smiles>[14CH3][18OH+]</smiles>

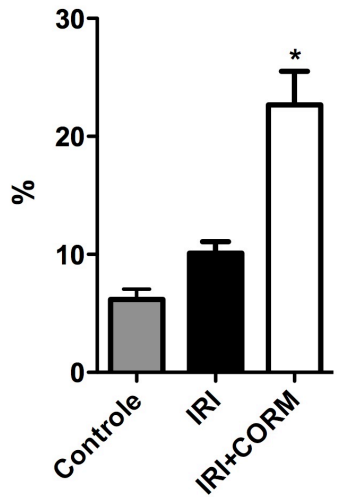

c.

TNF- $\alpha$

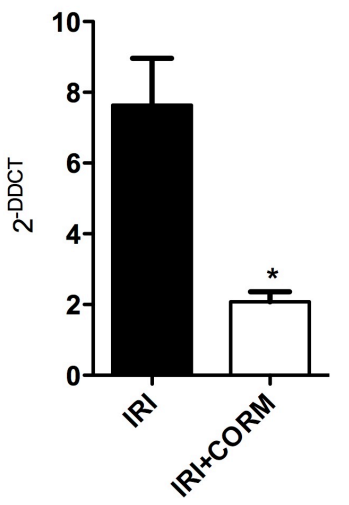

Amostras de tecido renal de animais tratados com CORM foram processadas e analisadas por citometria de fluxo. Os painéis A e B representam a porcentagem de macrófagos infiltrantes do perfil M1 e M2, respectivamente, 24 horas após a reperfusão. ${ }^{*} \mathrm{p}<0.05 \mathrm{vs}$ demais grupos.Em C, valor da expressão de TNF- $\alpha$ nos grupos IRI e IRI+CORM. ${ }^{*} p<0,05$ vs IRI. 
Figura 21 - Melhora da função renal de animais submetidos a IRI após o tratamento com CORM.

A.
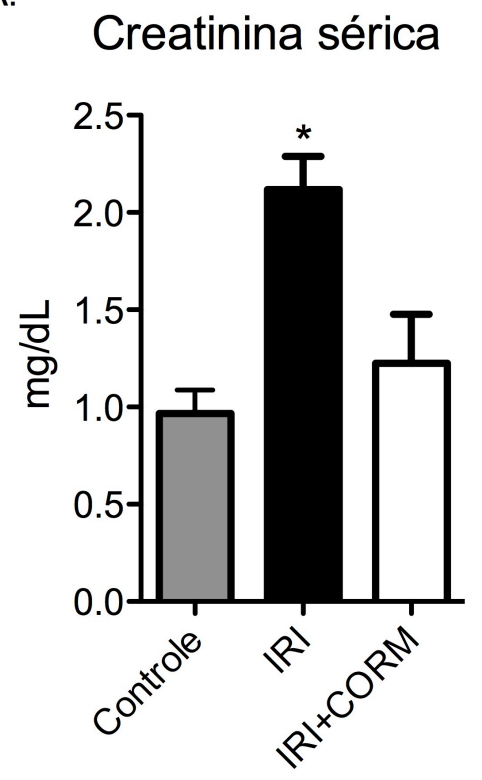

B.

\section{Uréia Sérica}

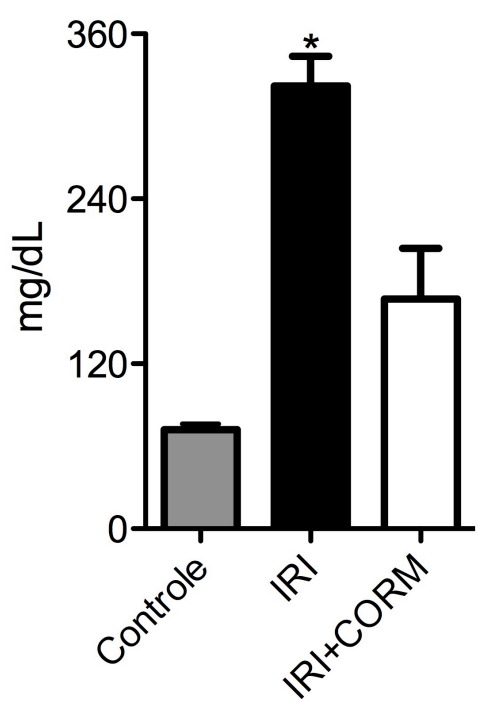

Níveis séricos de (A) Creatinina e (B) Uréia foram dosados de animais tratados ou não com CORM, que foram submetidos a IRI renal e sacrificados após 24 hs. ${ }^{*} \mathrm{p}<0.05$ vs demais grupos.

\subsection{Administração de CO na forma gasosa atenua a disfunção renal causada pela IRI}

Para verificar como o CO gera esse fenótipo citoprotetor, decidimos estudar mais profundamente os mecanismos pelos quais essa molécula estaria agindo na lesão isquêmica. Para tal, ao invés de usar o CORM, resolvemos fornecer o CO como gás inalado, numa concentração não-tóxica de 250 ppm e que já está sendo utilizada em ensaios clínicos nos EUA.

Inicialmente verificamos que o tratamento prévio com $\mathrm{CO}$, antes da cirurgia de IRI, leva a uma redução dos níveis séricos de creatinina e uréia, além de um melhor aspecto do tecido renal, com menos células mortas e menor infiltrado de células inflamatórias (Figura 22). Além disso, as células renais que foram expostas ao 
CO e em seguida foram submetidas ao modelo de HR apresentaram menos marcação para hipóxia e menor produção de ROS (Figura 23).

Figura 22 - Tratamento com CO previne a disfunção renal subsequente à IRI.

A.

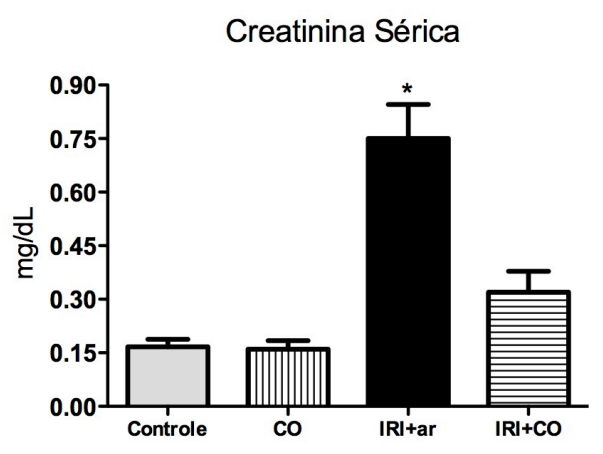

B.

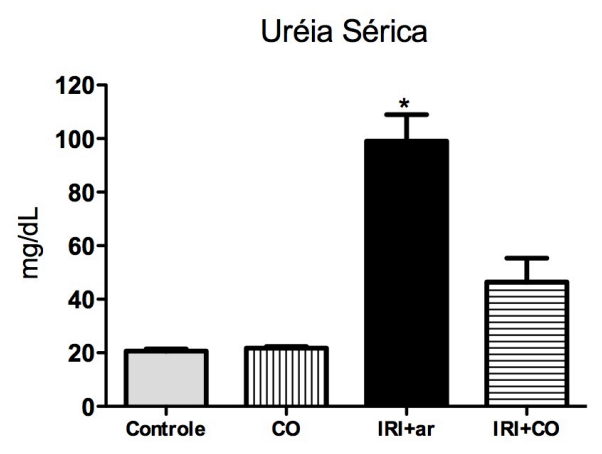

C.

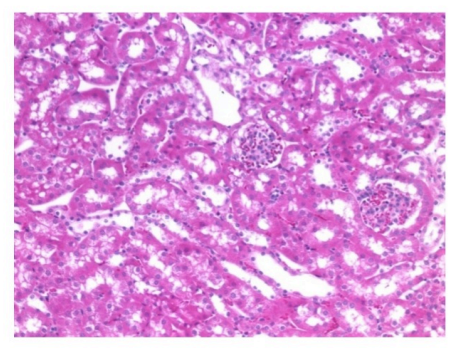

Controle

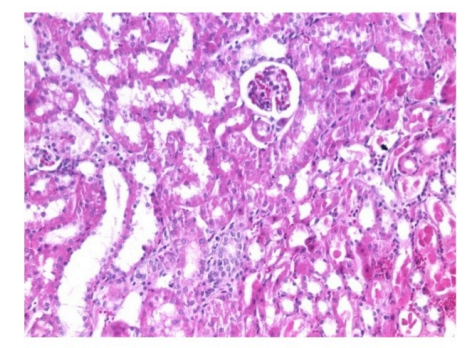

IRI + ar

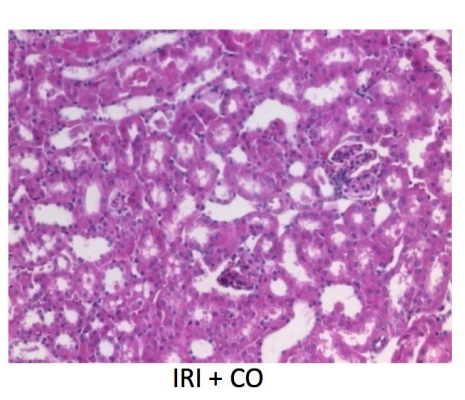

A função renal de animais controle $( \pm \mathrm{CO})$ e submetidos a IRI renal $( \pm \mathrm{CO})$ foi avaliada pela dosagem dos níveis séricos de (A) Creatinina e (B) Uréia. Em C, estão representadas imagens de tecido renal, coradas com HE. ${ }^{*} \mathrm{p}<0.05$ vs controles e IRI+CO. 
Figura 23 - Células renais expostas ao $\mathrm{CO}$ apresentam menos hipóxia e estresse oxidativo.
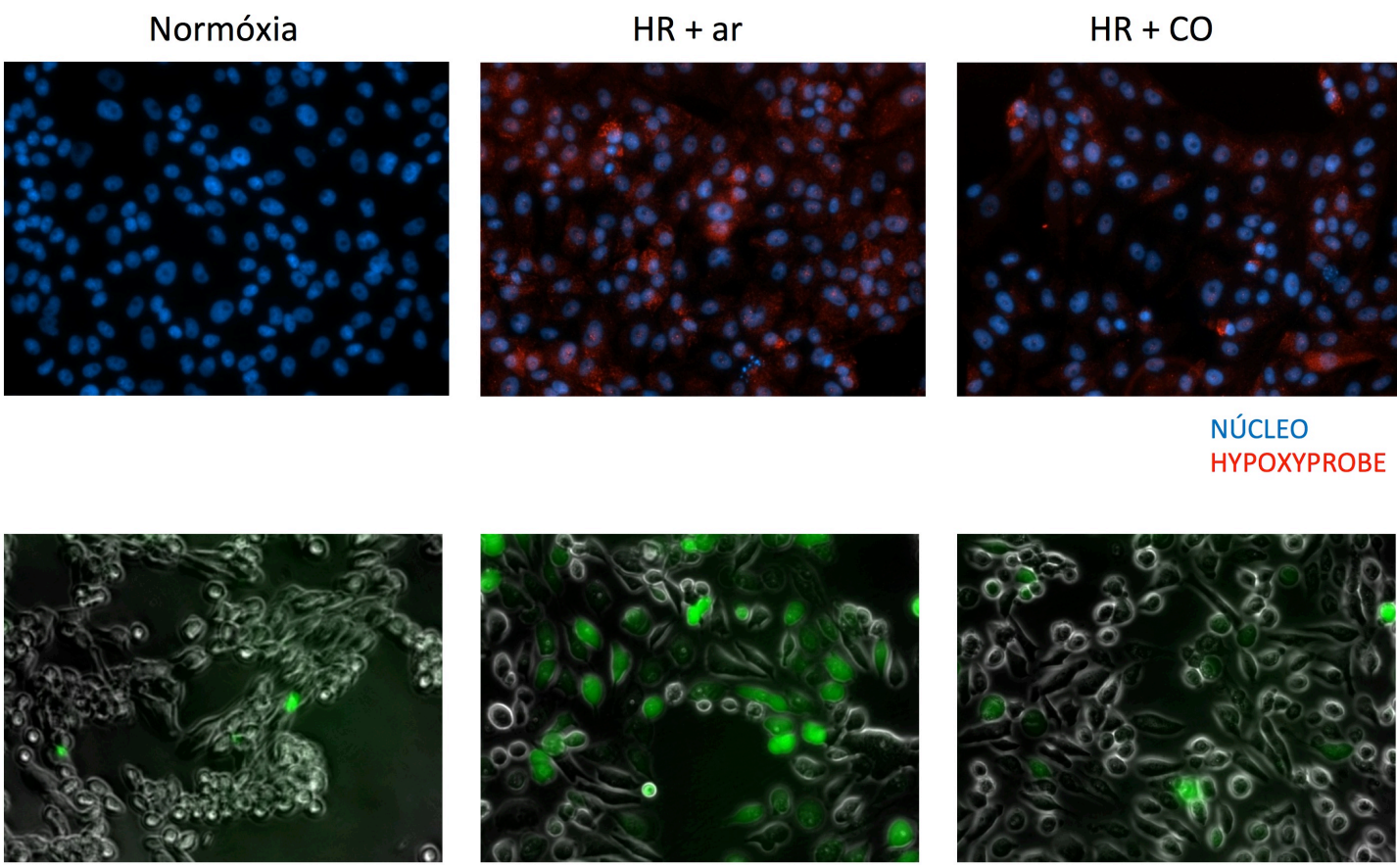

Espécies reativas de oxigênio

No painel superior estão representadas imagens das células marcadas com Hypoxiprobe (marcador de hipóxia - em vermelho) e DAPI (marcação nuclear - em azul). No painel inferior, pode-se ver, em verde, marcação para espécies reativas de oxigênio (ROS). As imagens são representativas de 3 experimentos.

A fim de avaliar mais detalhadamente o infiltrado celular, realizamos uma marcação específica para macrófagos e granulócitos e verificamos que nos animais tratados houve uma redução do número de células infiltrantes para ambas marcações (Figura 24, painéis A e B). O menor número de células infiltrantes somado à menor quantidade de ROS no grupo tratado com CO gerou uma redução do processo inflamatório no tecido renal, com uma expressão significativamente menor de TNF- $\alpha$ e concomitante aumento da expressão da citocina imunorregulatória, IL-10 (Figura 24, painéis $\mathrm{C}$ e D). Além disso, observamos também uma atenuação da produção de mediadores inflamatórios pela própria célula renal, com menor expressão de IL-1 $\beta$, MCP-1 e TNF- $\alpha$ (Figura 25). Em relação à última citocina, é importante destacar que logo após o início do período de reoxigenação não foi observado diferença nenhuma 
entre os grupos, mas ao fim desse período o grupo que não recebeu CO produziu significativamente mais TNF- $\alpha$ do que os grupos controle e $\mathrm{HR}+\mathrm{CO}$, mostrando que a fase de reoxigenação contribui de forma marcante para o desenvolvimento da injúria (Figura 25C).

Juntos, esses resultados mostram que a exposição ao CO leva a uma menor formação de ROS e menor infiltração de granulócitos e macrófagos. A isso, soma-se uma melhora do processo inflamatório e subsequente redução da morte celular e melhora da função renal. 
Figura 24 - A exposição ao $\mathrm{CO}$ reduz o número de células infiltrantes no rim e, consequentemente, o processo inflamatório.

A.

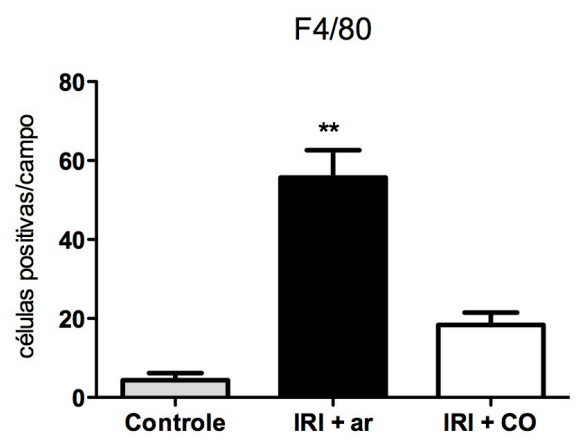

C.

TNF- $\alpha$

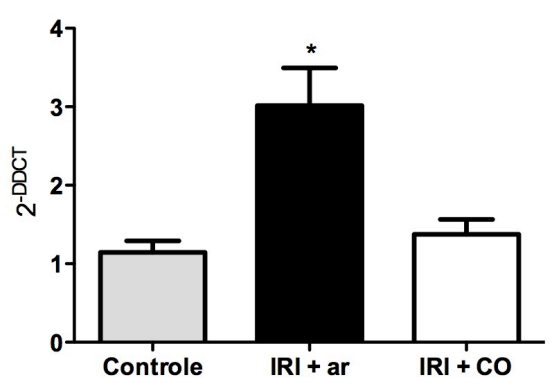

B.

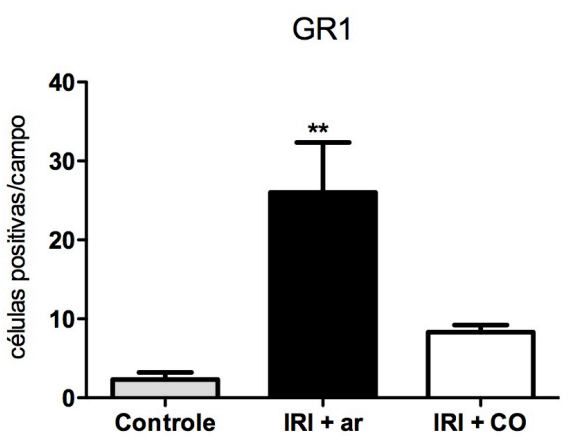

D.

IL-10

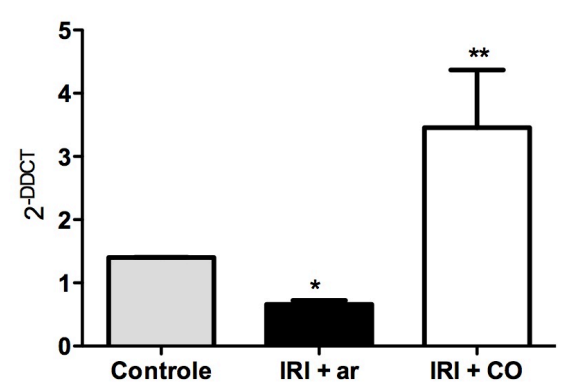

Animais controle e aqueles submetidos a lesão renal isquêmica e que foram tratados ou não com CO foram avaliados pela presença de macrófagos (F4/80) ou neutrófilos/granulócitos (GR1), como pode ser visto nos painéis A e $B$, respectivamente. ${ }^{* *} \mathrm{p}<0.01$ vs Controle e IRI+CO. Em C e D encontra-se a análise da expressão gênica no tecido renal de TNF- $\alpha\left({ }^{*} \mathrm{p}<\right.$ 0.05 vs Controle e IRI+CO) e IL-10 (* $\mathrm{p}<0.05$ vs Controle e ${ }^{* *} \mathrm{p}<0.001$ vs Controle e IRI+ar). 
Figura 25 - Exposição de células renais ao CO inibe a inflamação no modelo in vitro de lesão isquêmica.

A.

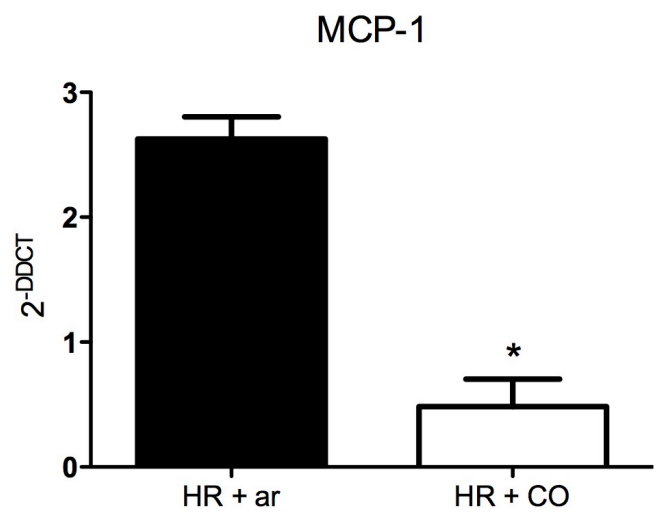

B.

$\mathrm{IL}-1 \beta$

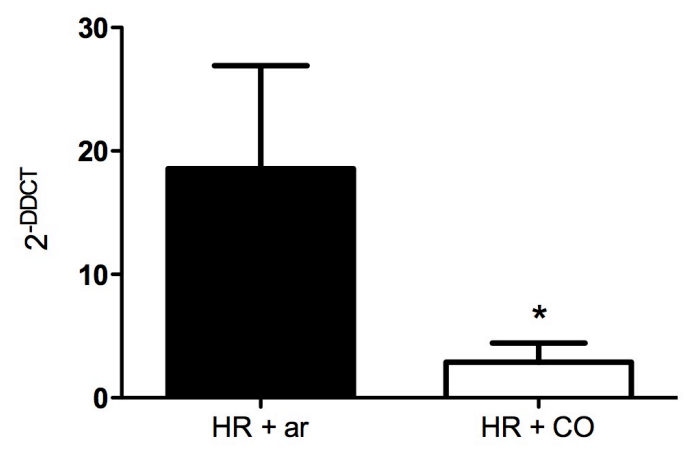

C.

TNF- $\alpha$

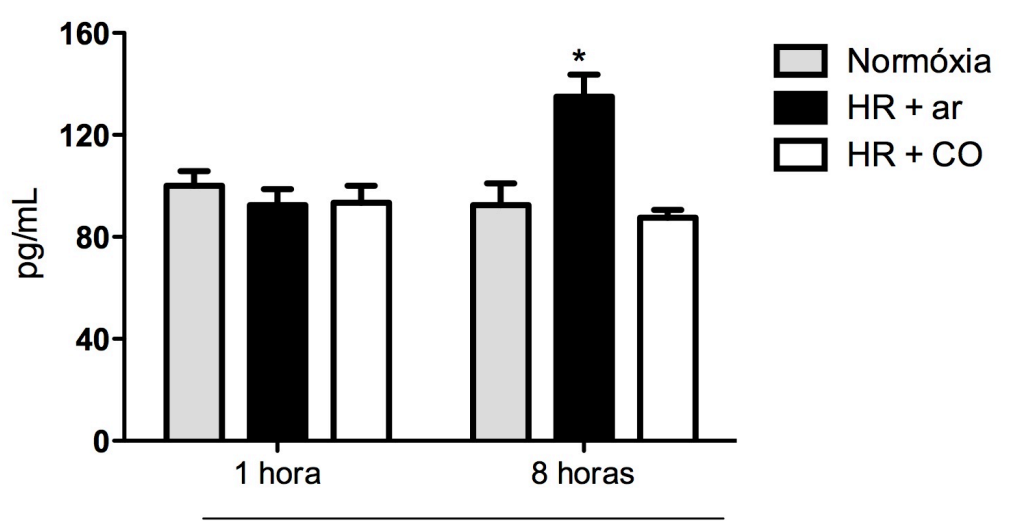

Tempo pós-reoxigenação

Em A e B, observa-se a expressão de transcritos de MCP-1 e IL-1 $\beta$, respectivamente, nas células renais submetidas ao modelo de HR ( ${ }^{*} \mathrm{p}<0.05$ vs HR+ar). Em $\mathrm{C}$, foram avaliados os níveis de TNF- $\alpha$ do sobrenadante de cultura celular das células descritas previamente $\left({ }^{*} \mathrm{p}<\right.$ 0.05 vs Controle e $\mathrm{HR}+\mathrm{CO}$ ). Os dados são de 3 experimentos independentes. 


\subsection{A proteção mediada pelo CO acontece desde um estágio inicial da reperfusão}

A fim de avaliar como alguns eventos moleculares estariam acontecendo num período prematuro na fase de reperfusão, decidimos sacrificar os animais após 2 e 6 horas de reperfusão. Ao fazermos a marcação para hipóxia com Hypoxyprobe nos tecidos renais dos animais que sofreram IRI e foram tratados ou não com $\mathrm{CO}$, observamos que somente no grupo não tratado há uma marcação forte para esse composto, desde estágios iniciais após a reoxigenação do órgão. Ainda, os animais que somente receberam $\mathrm{CO}$ e não foram submetidos a nenhum procedimento cirúrgico não apresentaram marcação para hipóxia (Figura 26). 
Figura 26 - Animais submetidos a IRI e tratados com CO exibem menos marcação para hipóxia num momento inicial após a reperfusão.
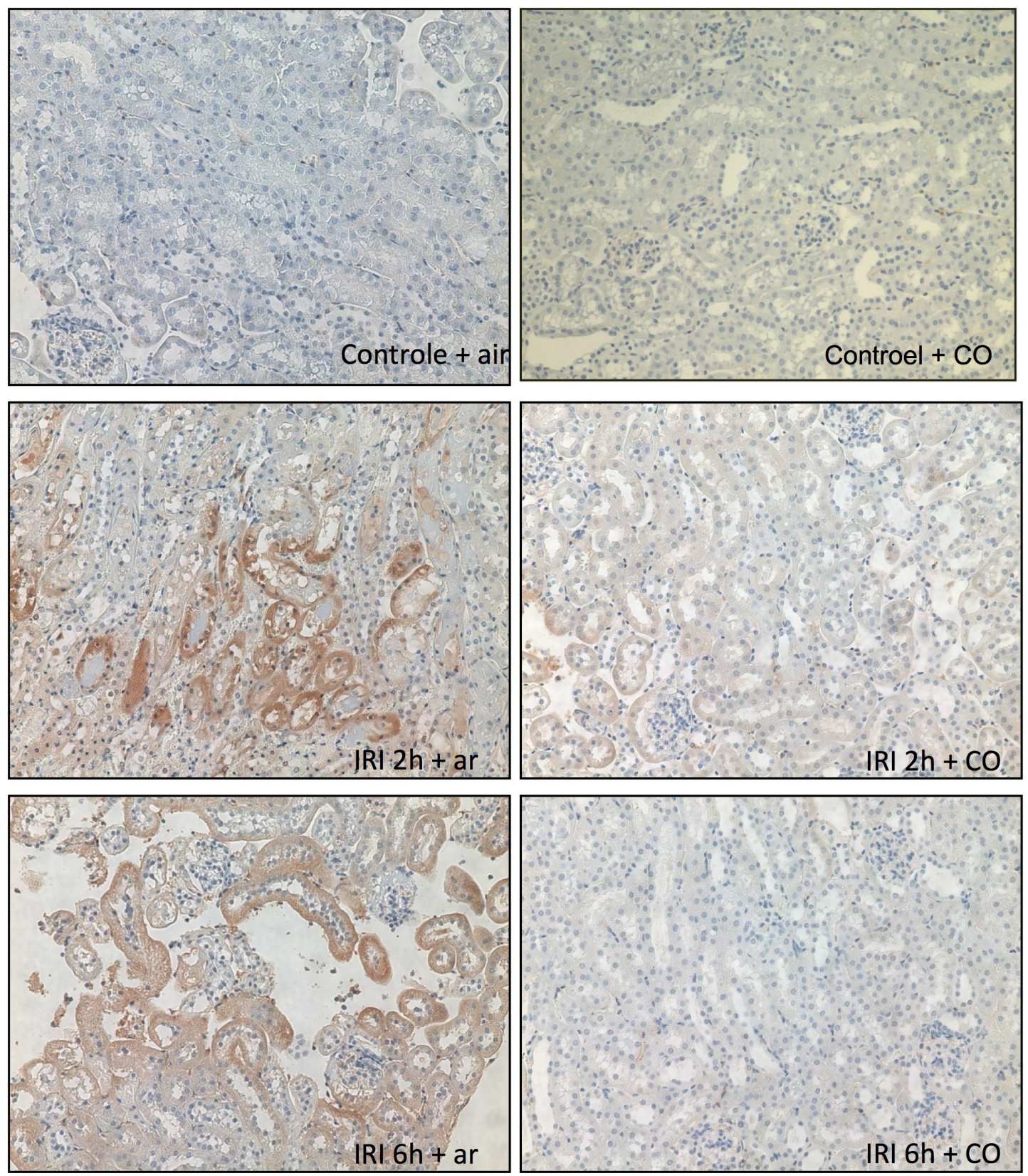

A marcação para hipoxyprobe foi feita por imunohistoquímica nos grupos indicados. A presença de uma marcação mais escura indica os locais onde o tecido renal sofreu hipóxia. 
Além disso, o número de macrófagos e granulócitos infiltrantes no tecido renal era significativamente menor no grupo exposto ao $\mathrm{CO}$, nos estágios recentes após a reperfusão do órgão (Figura 27, painéis A e B). Da mesma forma, a produção de TNF- $\alpha$ no tecido renal dos animais submetidos a IRI estava significativamente menor no grupo que recebeu $\mathrm{CO}$, quando comparado ao grupo não tratado, e essa produção diminuída nos animais tratados foi verificada durante todos os pontos avaliados (Figura 27C). Esses dados indicam que precocemente, na presença de CO, a célula renal sofre menos hipóxia com concomitante menor infiltração de leucócitos e consequentemente menor produção de TNF- $\alpha$.

Finalmente, o tratamento com CO também levou a uma atenuação do ERS após a IRI renal, observada por menores níveis protéicos de BiP e CHOP. Além disso, no modelo in vitro de HR, observou-se uma redução dos níveis de BiP, corroborando os dados in vivo (Figura 28). 
Figura 27 - O tratamento com CO reduz a inflamação inicial causada pela IRI renal.

A.

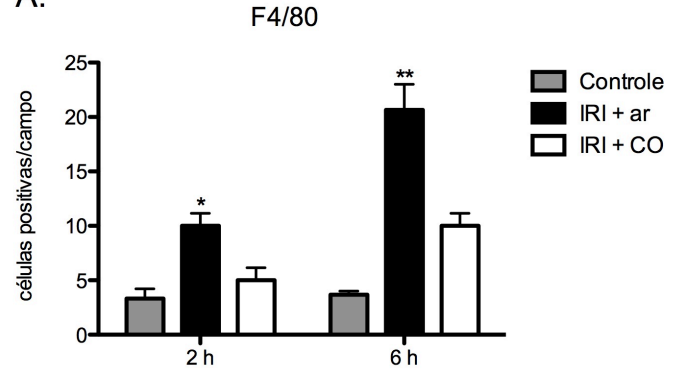

B.

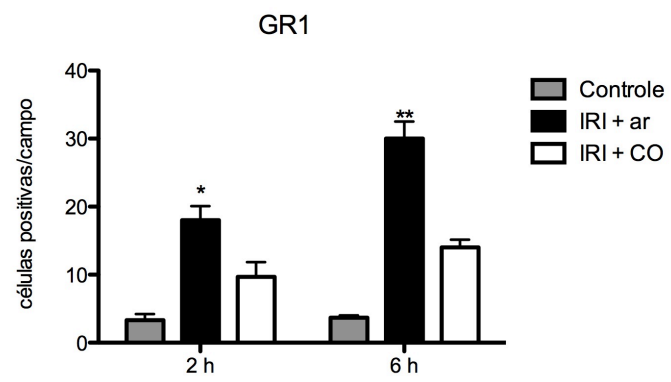

C.

TNF- $\alpha$

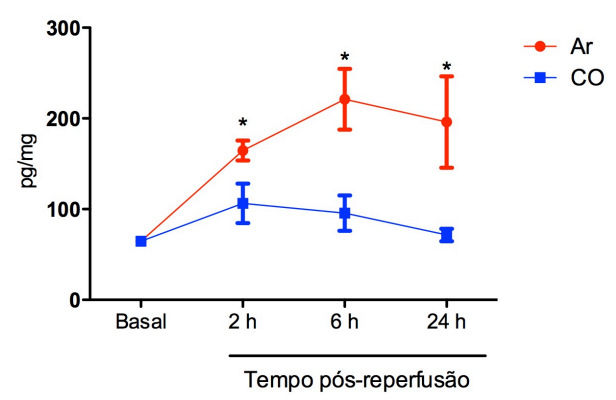

A avaliação de macrófagos (células F4/80) e neutrófilos (células GR1) infiltrantes no tecido renal foi feita nos tempos indicados e a quantificação gráfica é mostrada em $\mathrm{A}$ e B, respectivamente. Em $C$, pode-se observar a dosagem de TNF- $\alpha$ nos tecidos de animais submetidos a IRI e tratados ou não com $\mathrm{CO} .{ }^{*} \mathrm{p}<0.05$ vs controle e IRI+CO. ${ }^{* *} \mathrm{p}<0,01$ vs controle e IRI+CO. 
Figura 28 - Atenuação de marcadores do ERS após a exposição ao CO.

A.
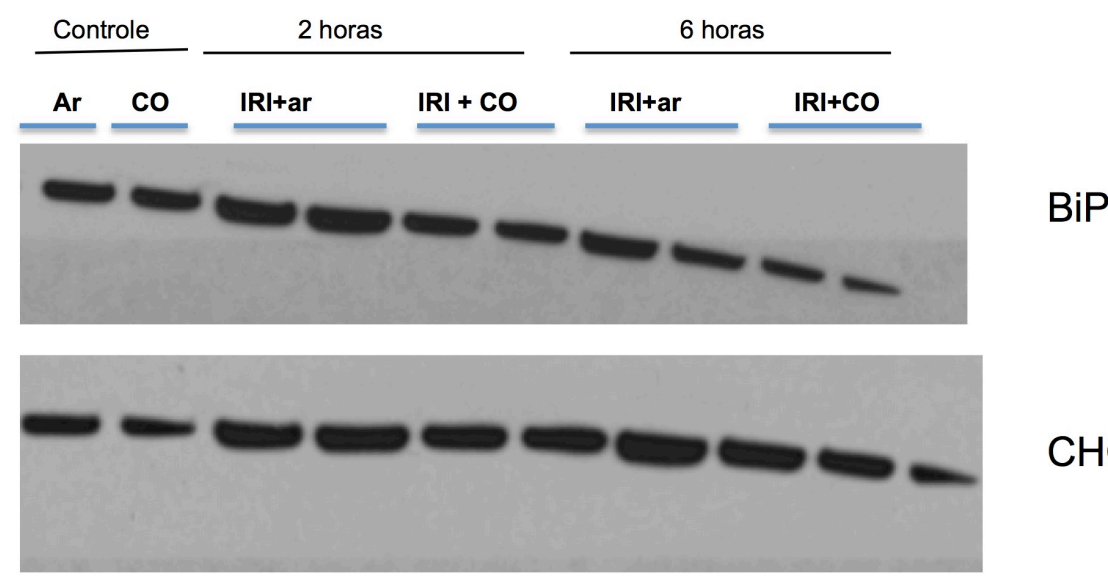

$\mathrm{CHOP}$

B.

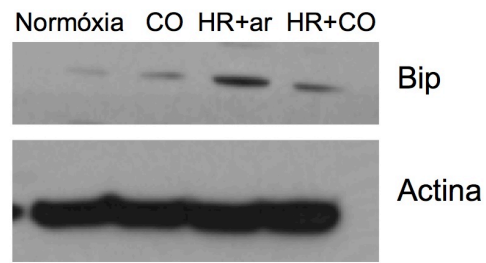

Em A, animais controle (que receberam ou não $\mathrm{CO}$ ) e aqueles submetidos à IRI renal (também expostos ou não ao $\mathrm{CO}$ ) tiveram suas amostras de rim processadas para avaliação dos níveis protéicos dos marcadores de ERS, BiP e CHOP. Já o painel B indica amostras de células submetidas ao modelo de $\mathrm{HR} \pm \mathrm{CO}$, marcadas com anticorpo anti-BiP.

Assim, podemos sugerir que o sistema $\mathrm{HO}-1 / \mathrm{CO}$ age desde momentos iniciais do início do insulto renal, gerando uma sinalização que contribui para a atenuação e/ou prevenção do desenvolvimento da lesão renal posterior. 


\subsection{O CO age via regulação positiva da molécula Per2 e da sinalização purinérgica}

Recentemente, foi identificado que a ligação da adenosina ao seu receptor Adora2 aumentaria a expressão da molécula do ritmo circadiano Per2, sendo essa uma via importante para a resposta protetora à isquemia cardíaca [141]. Como já foi descrito que o CO aumenta a expressão desses mesmos receptores [142], formulamos a hipótese de que o possível mecanismo envolvido na proteção do órgão lesado após o tratamento com CO poderia ser pelo eixo Adora2-Per2.

Inicialmente, verificamos que o rim de animais controle apresenta uma variação circadiana da expressão de Per2, sendo sua menor expressão verificada no início da manhã (ZT3) e seu pico no final da tarde (ZT9) (Figura 29A). A fim de confirmar que a presença dessa molécula é importante para o reparo tecidual após um evento isquêmico, realizarmos o modelo de IRI nos tempos descritos acima e verificamos que quando a molécula Per2 apresenta sua maior expressão, a disfunção renal causada pelo procedimento cirúrgico é menor (Figuras 29B e 29C). 
Figura 29 - A molécula Per2 exibe um ciclo circadiano no rim.

A. PER2

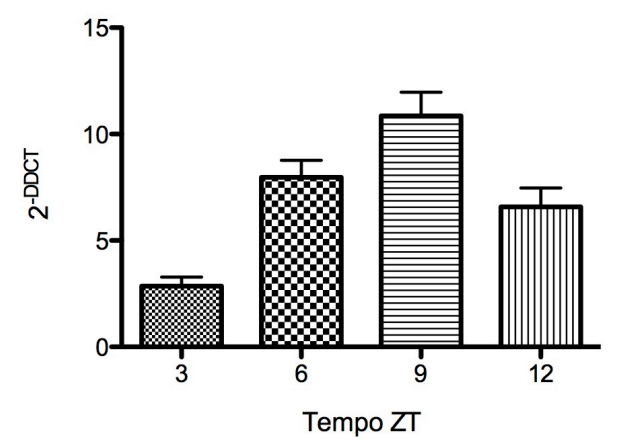

B.

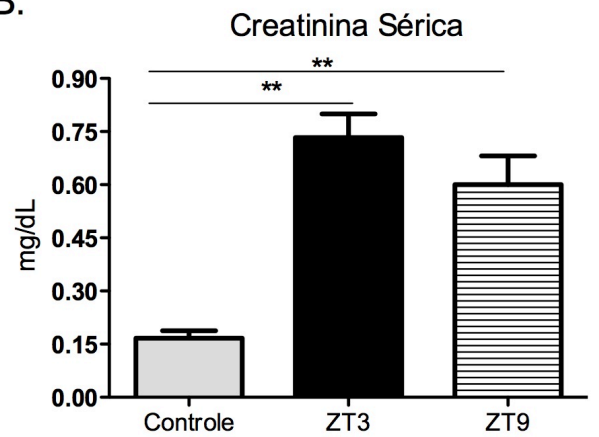

C.

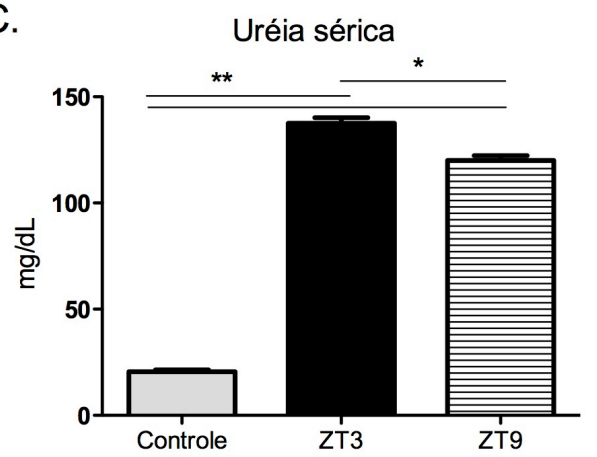

A. Rins de animais sem cirurgia foram coletados em diferentes períodos do dia para avaliação dos níveis de Per2 (ZT3 - 9-12 h; ZT6 - 12-15 h; ZT9 - 15-18 h; ZT12 - 18-21 h). Em $B$ e $C$, avaliação dos níveis séricos de Creatinina e Uréia foram avaliados em animais submetidos à IRI em diferentes ZT ( ${ }^{* *} \mathrm{p}<0.001$ vs Controle $\mathrm{e}^{*} \mathrm{p}<0.05$ vs ZT3).

Aliado a esses dados, ao avaliarmos os rins de animais controle que foram tratados com $\mathrm{CO}$ por 1 hora e que imediatamente tiveram seus órgãos coletados, observamos uma redução significativa da expressão do receptor Adora1 e aumento significativo da expressão do receptor Adora2b. Interessantemente, não houve diferença em relação aos níveis do receptor Adora2a (Figura 30, painéis A-C). 
Figura 30 - Receptores de adenosina (Adora) são modulados pelo CO.

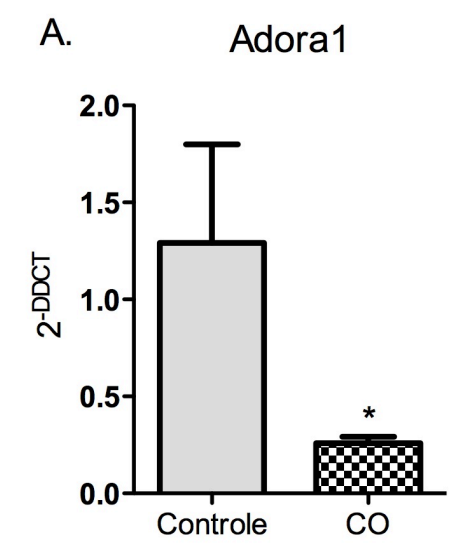

B.

Adora2a

C. Adora2b
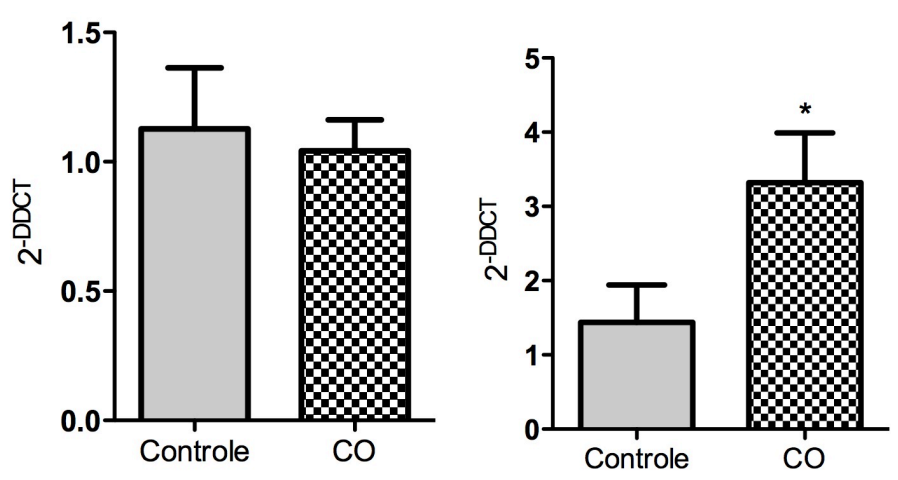

Animais controle que receberam $\mathrm{CO}$ por 1 hora tiveram seus rins coletados e avaliados para os transcritos gênicos de Adora 1 (A), Adora2a (B) e Adora2b (C). ${ }^{*} \mathrm{p}<0.05$ vs controle.

Como a geração de adenosina é dependente de ATP, fomos verificar os níveis dessa molécula no sobrenadante das células submetidas à HR. Conforme observado na figura 31A, após a lesão isquêmica há uma queda da liberação de ATP para o meio extracelular, fato revertido nas células previamente tratadas com CO. Além disso, nos animais expostos ao $\mathrm{CO}$, observamos um aumento significativo da expressão de CD39 (Figura 31, painel B), a ectonucleotidase responsável pela conversão de ATP em ADP e AMP (que posteriormente é convertido em adenosina por outra ectonucleotidase, o CD73). 
Figura 31 - Exposição ao CO reverte a queda da produção de ATP subsequente à lesão isquêmica e aumenta a expressão de CD39.

A.

ATP - sobrenadante

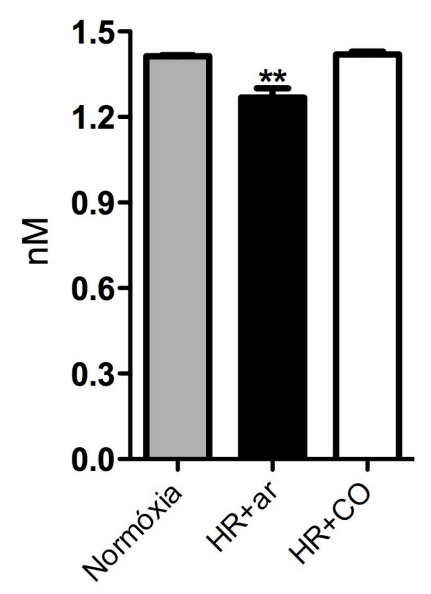

B.

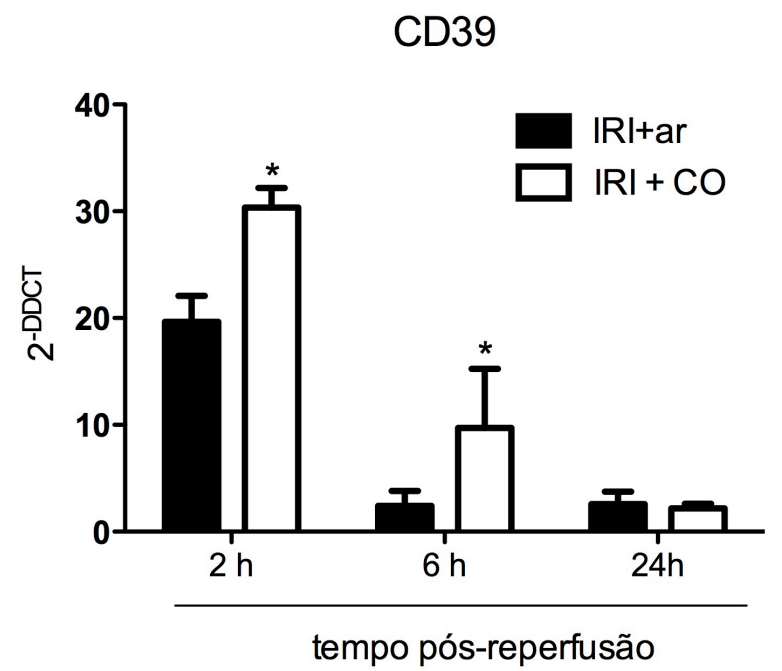

Os níveis de ATP no sobrenadante de células que ficaram em normóxia, ou submetidas ao modelo de $\mathrm{HR}$ e tratadas ou não com $\mathrm{CO}$ pode ser vista no painel A. No painel B pode-se observar como o CO interfere na modulação da expressão gênica de CD39. * $\mathrm{p}<0.05$ vs IRI+ar.

Falando especificamente dos receptores para adenosina, verificamos que após a cirurgia de IRI, o grupo de animais tratados com CO mostrou uma expressão significativamente menor de Adora1 quando comparado ao grupo que não recebeu nenhum tratamento (Figura 32, painel A). Em contrapartida, observamos o fenômeno oposto quando verificamos a expressão gênica de Adora2a e Adora2b (Figuras 32, painéis $\mathrm{B}$ e $\mathrm{C}$ )

Os receptores Adora2 são acoplados à proteína G estimulatória e a sua ativação leva ao aumento dos níveis de cAMP. Assim, conforme observado na Figura 32D, podemos verificar que no grupo tratado com CO há um aumento significativo dos níveis de cAMP. 
Figura 32 - Tratamento com CO regula positivamente a sinalização purinérgica antiinflamatória.

A.

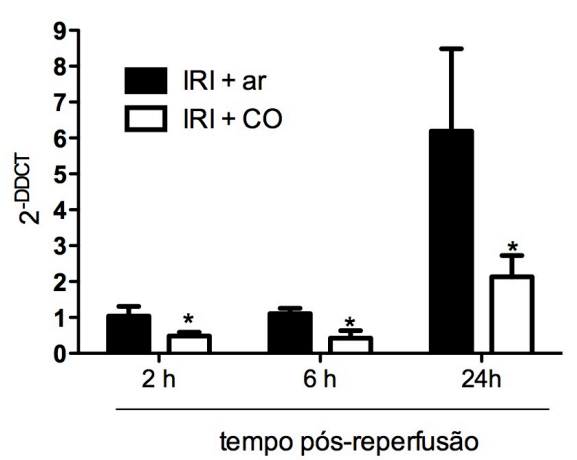

C.

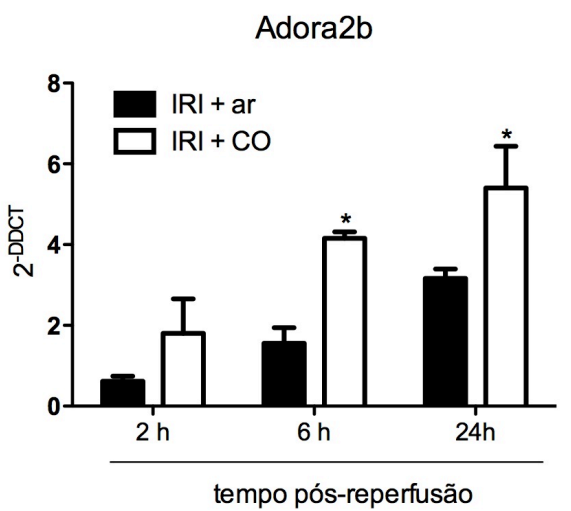

B. Adora2a

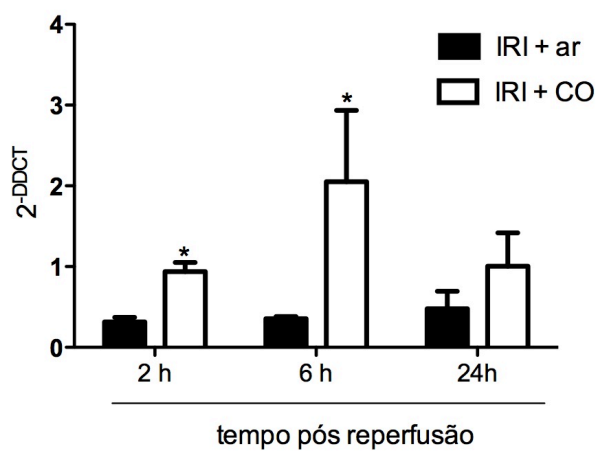

D.

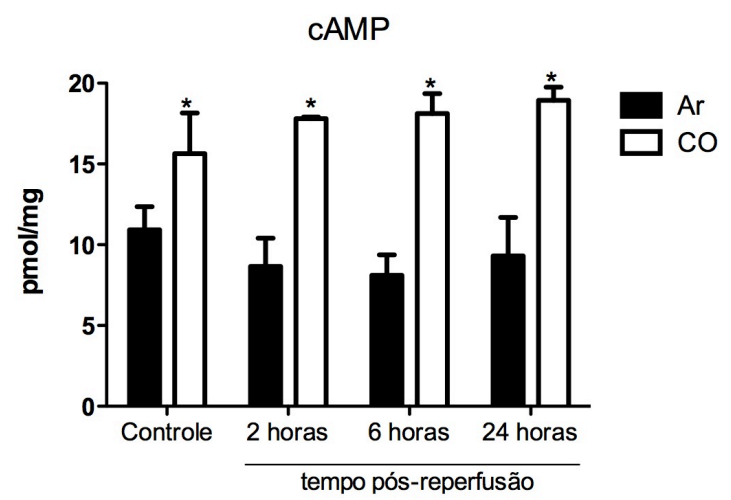

Amostras de rim de animais que sofreram IRI renal $\pm \mathrm{CO}$ foram processadas e os níveis de RNAm de Adora1, Adora2a e Adora2b foram avaliados, conforme observado nos painéis $\mathrm{A}$, $B$ e $C$, respectivamente. Em D, os níveis intracelulares de cAMP de animais tratados ou não com $\mathrm{CO}$ e submetidos a IRI foram dosados. ${ }^{*} \mathrm{p}<0.05$ vs IRI+ar. 
Somado a esse fato, podemos observar também que ocorre um aumento da expressão de Per2 nesses mesmos animais (Figura 33A). Como consequência, verificamos um aumento da expressão protéica de HIF-1 $\alpha$ no grupo tratado com $\mathrm{CO}$ (Figura 33B), confirmando o papel da Per2 como agente estabilizador para o HIF-1 $\alpha$.

Figura 33 - CO gera uma sinalização intracelular que favorece a estabilização de HIF$1 \alpha$.

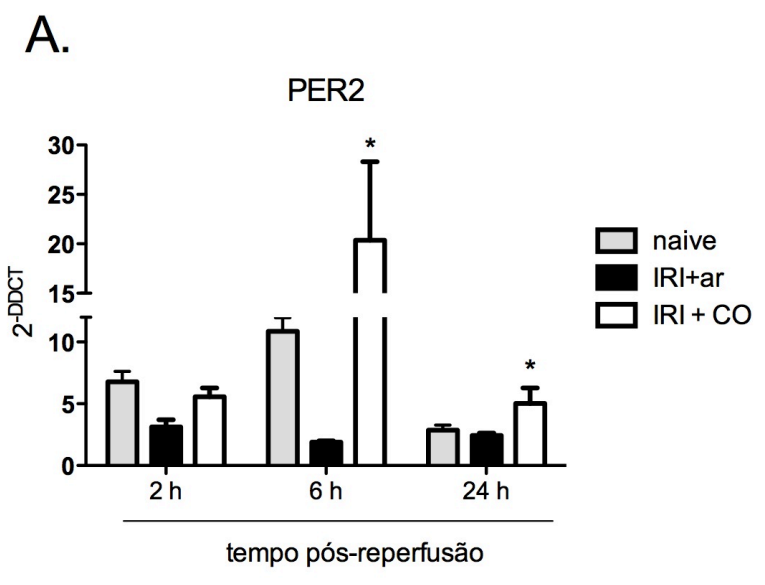

B.

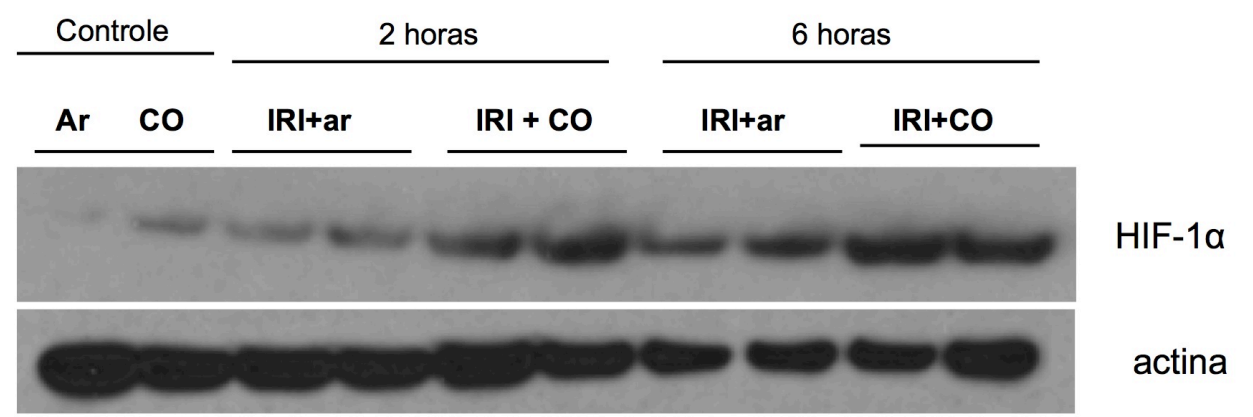

Em A, pode-se verificar os níveis de transcritos gênicos de Per2 dos animais naive (sem cirurgia), tratados ou não com $\mathrm{CO}$ e submetidos a IRI. Em B, representação da expressão protéica de HIF- $1 \alpha .{ }^{*}$ p $<0.05$ vs IRI+ar. 


\subsection{A EPO medeia a proteção observada após o tratamento com CO}

Após sua estabilização, o HIF-1 $\alpha$ transloca-se para o núcleo e promove a transcrição de alguns genes alvos, com o objetivo de acelerar a adaptação à condição adversa encontrada pela célula lesada. Uma vez que um dos principais genes alvo é a EPO, decidimos avaliar como o tratamento com CO influenciaria nesse parâmetro. Como é possível verificar na Figura 34A, os níveis séricos de EPO estão significativamente aumentados no grupo tratado com $\mathrm{CO}$ desde períodos iniciais após a reperfusão e se mantém aumentados até 24 horas após a reoxigenação dos rins. Além disso, observamos um aumento da expressão do receptor de EPO (EPOR) no tecido renal (Figura 34B).

Figura 34 - EPO está aumentada após exposição de animais ao CO.

A.

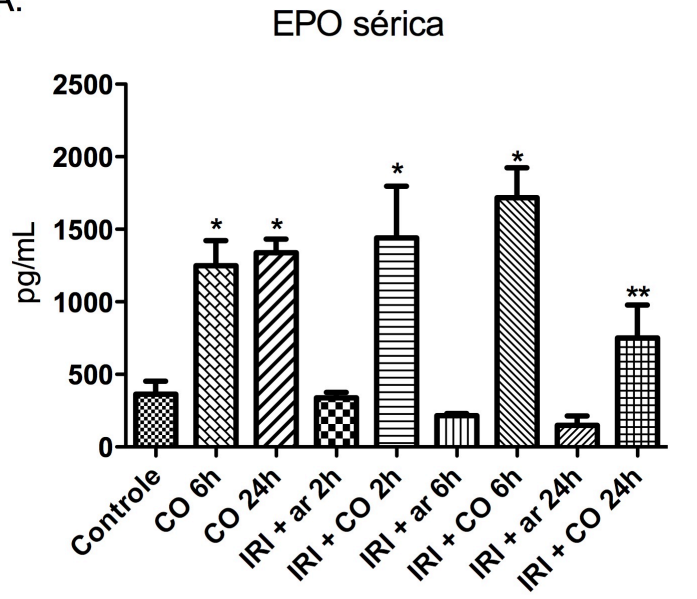

B.

\section{Tecido Renal}

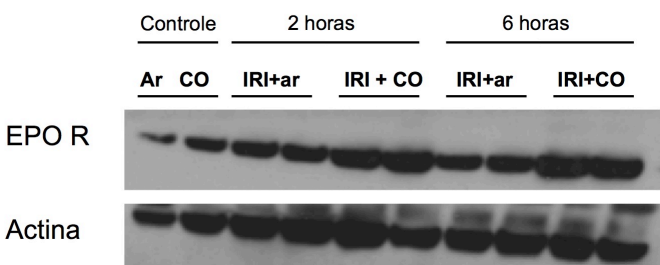

Os níveis séricos de EPO foram dosados nos grupos e tempos indicados no painel A. Em B, pode-se ver uma representação dos níveis protéicos do receptor de EPO no tecido renal. Em $\mathrm{C}$, observa-se a cinética de EPO sérica após a administração de $\mathrm{rEPO} \pm \mathrm{CO}$. Em $\mathrm{D}$, a dosagem de EPO foi feita após nefrectomia. ${ }^{*} \mathrm{p}<0.001$ vs controle ou respectivos grupos IRI+ar; ${ }^{* *}$ $p<0,01$ vs IRI+ar $24 h$. 
Com a finalidade de definir se a presença do CO leva a um aumento da produção de EPO ou a uma redução de sua metabolização, decidimos dar eritropoietina recombinante aos animais e colocá-los na presença ou não de $\mathrm{CO}$, medindo os níveis de EPO após a exposição ao gás. Conforme observado na Figura $35 \mathrm{~A}$, não há diferença em relação à cinética dos grupos tratados ou não tratados, o que nos leva a inferir que o CO age aumentando a produção desse hormônio. Além disso, uma vez que sabemos que o rim é o principal órgão produtor de EPO na idade adulta, resolvemos fazer a nefrectomia total dos animais e tratá-los ou não com CO, avaliando os níveis de EPO 6 horas após a exposição ao ar ou CO. A Figura 35, painel B, nos mostra que os níveis séricos de EPO continuam aumentados no grupo que recebeu $\mathrm{CO}$, mesmo sem a presença dos rins, sugerindo que o tratamento com $\mathrm{CO}$ tem um efeito sistêmico, agindo em outros órgãos não envolvidos com a lesão inicial.

Figura 35 - Efeito do CO sobre a metabolização e produção de EPO

A.

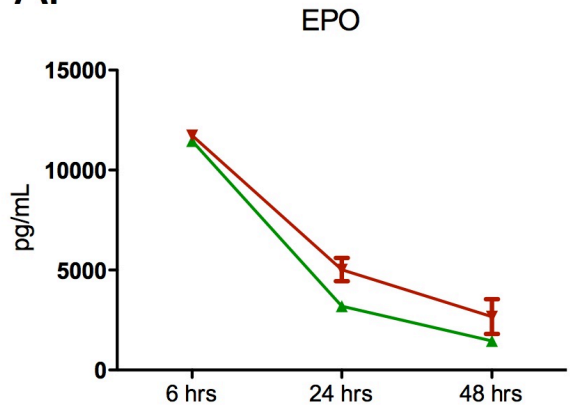

B.

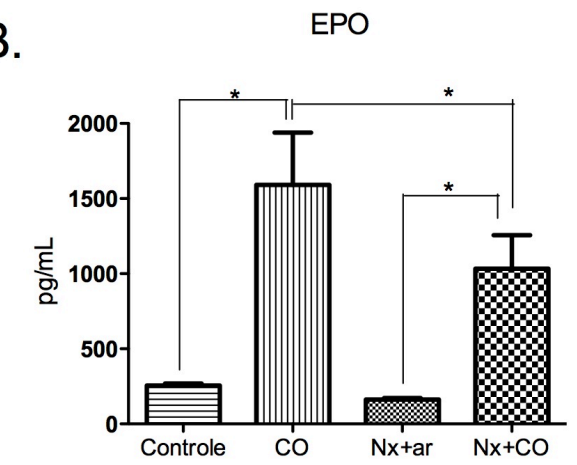

No painel A, observa-se a cinética de EPO sérica após a administração de $\mathrm{rEPO} \pm \mathrm{CO}$. Em B, a dosagem de EPO foi feita após nefrectomia bilateral. ${ }^{*} \mathrm{p}<0.01$.

Uma vez que a administração de EPO tem se mostrado benéfica em modelos de lesão renal, com destaque para seus efeitos anti-inflamatórios [143] decidimos verificar se a proteção observada após o tratamento com $\mathrm{CO}$ era mediada pela presença desse hormônio. Para tal, foi administrado nos animais um anticorpo neutralizante para EPO ou um anticorpo IgG controle. Em ambos os casos, os animais foram tratados com CO e submetidos a cirurgia de IRI. No período de 24 
horas após a reperfusão, verificamos que os animais que receberam o anticorpo neutralizante para EPO perderam a proteção observada após o tratamento com $\mathrm{CO}$, processo que não ocorreu após a administração do isotipo IgG controle (Figura 36 AD). Ainda, é interessante notar que os níveis de cAMP permaneceram iguais em todas as condições (animal tratado com CO, animal que recebeu o anticorpo neutralizante para EPO e animal que recebeu IgG Controle), corroborando a idéia de que a produção de EPO está downstream à sinalização mediada por cAMP (Figura 36, painel E). 
Figura 36 - A proteção vista após o tratamento com CO é mediada pela EPO.

A.

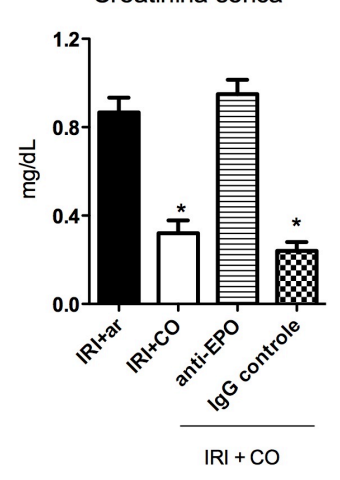

D.

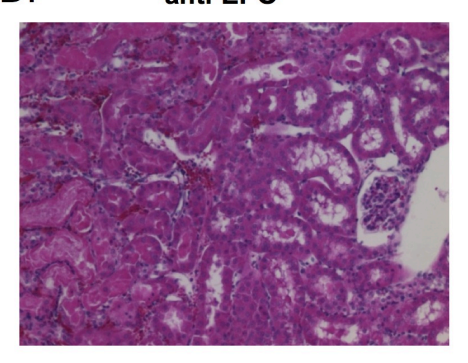

B.
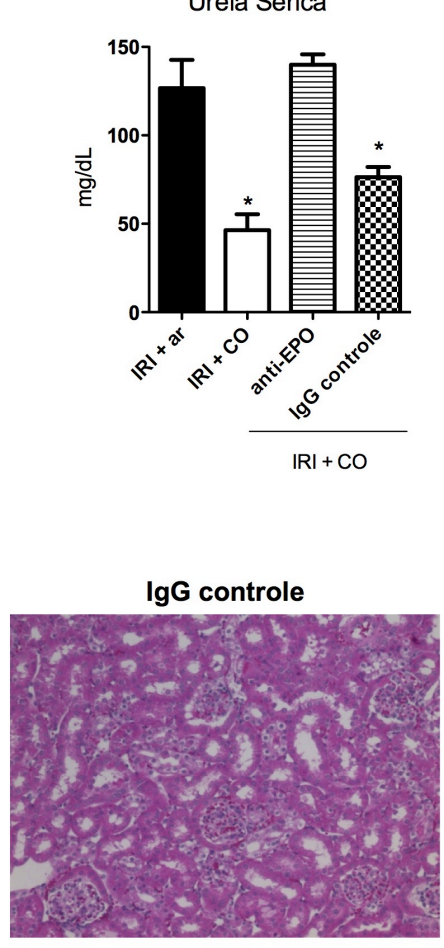

C. TNF- $\alpha$

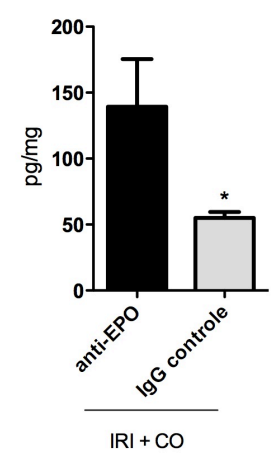

E.

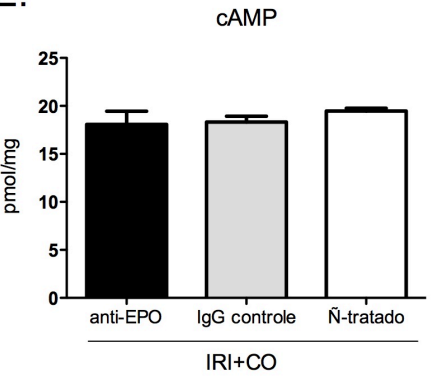

Animais tratados com anticorpo neutralizante para EPO ou IgG controle foram tratados com $\mathrm{CO}$ e submetidos à IRI renal. Mesmo com a exposição ao $\mathrm{CO}$, o bloqueio de EPO gerou disfunção renal (A - níveis de creatinina sérica e B - Uréia sérica), maior produção de TNF- $\alpha$ no tecido renal (painel C) e uma piora do aspecto histológico (painel D). Os níveis de cAMP intracelular estão indicados no painel E. * $\mathrm{p}<0.05$ vs anti-EPO.

\subsection{CO depende da produção de adenosina e de sua ligação ao receptor do tipo 2 para exercer seu efeito protetor}

Uma vez que o CD39 é um fator importante na produção de adenosina, decidimos utilizar animais CD39KO para verificar se essa ectonucleotidase é importante para a sinalização mediada pelo CO. Observamos que a falta de CD39 promove uma piora da função renal após a lesão de isquemia e reperfusão, com aumento dos níveis séricos de creatinina e uréia (Figura 37), além de uma elevação na expressão de TNF- $\alpha$ (Figura 38, painel A). O tratamento com CO nos animais CD39KO não foi capaz de reverter tal quadro, mostrando que o CO precisa do CD39 
para efetivamente promover uma proteção ao insulto renal. Além disso, uma vez que não há formação de adenosina, os níveis de cAMP, Per2 e EPO ficaram significativamente reduzidos nos animais CD39KO, quando comparados aos animais selvagens (WT) que receberam $\mathrm{CO}$. Novamente, o tratamento com $\mathrm{CO}$ não se mostrou eficaz no grupo de animais nocautes (Figura 38, painéis B-D).

Figura 37 - Aumento da disfunção renal subsequente à IRI renal em animais geneticamente deficientes para CD39.

A.

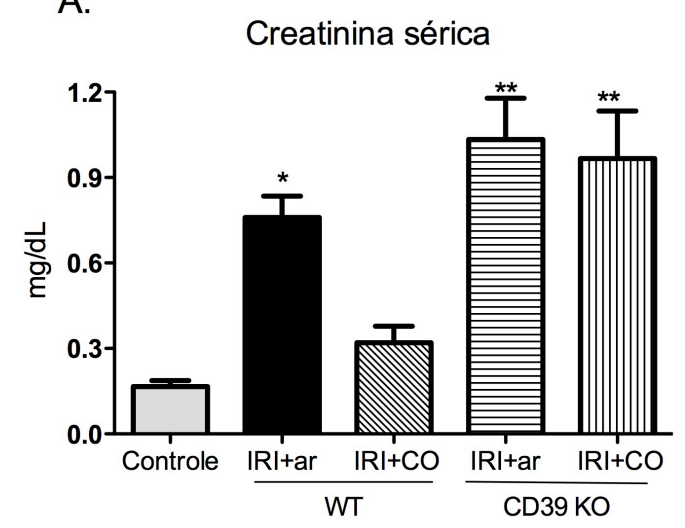

B.

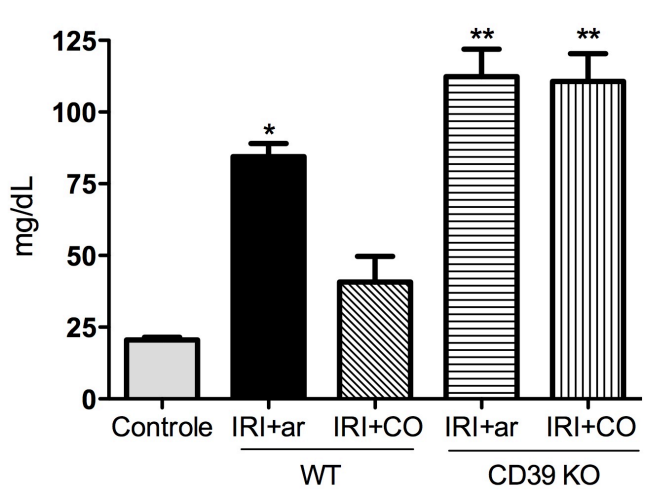

Os níveis séricos de creatinina (painel A) e uréia (painel B) foram dosados em animais WT e CD39 KO, submetidos ou não ao tratamento com CO. ${ }^{*} \mathrm{p}<0,05$ vs Controle e IRI+CO WT; ${ }^{* *}$ $\mathrm{p}<0,05$ vs demais grupos. 
Figura 38 - CO depende de CD39 para exercer seu efeito protetor.

A.

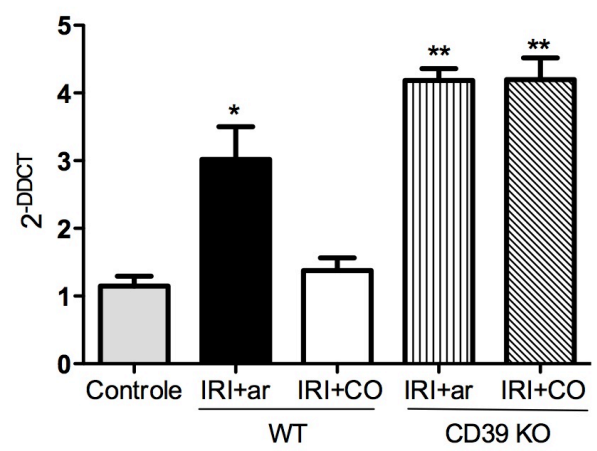

C.

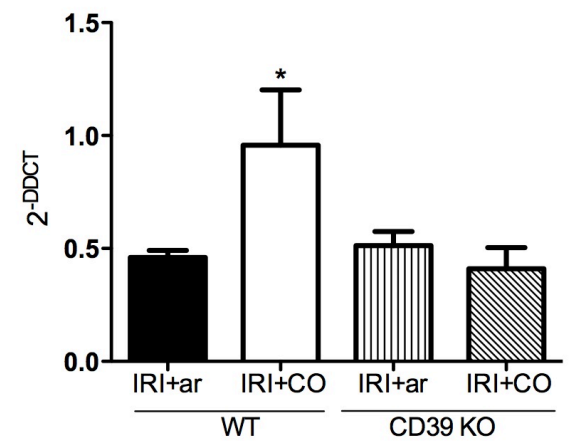

B.

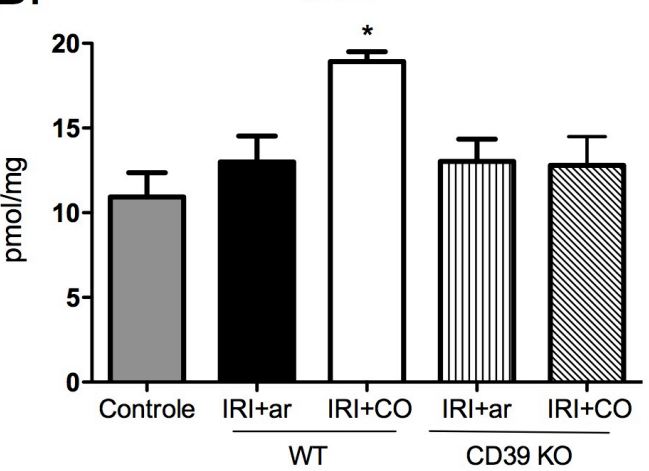

D.

EPO

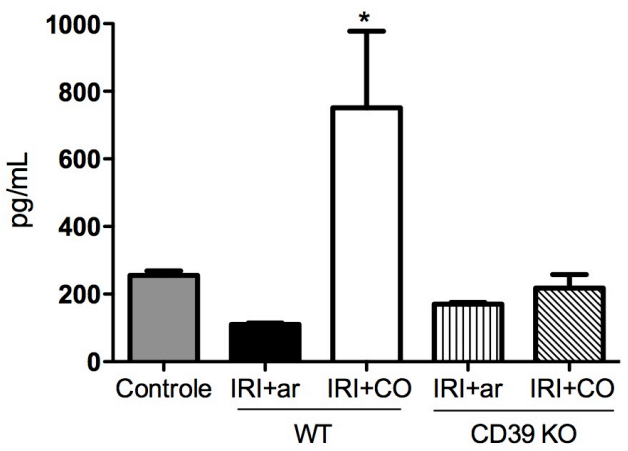

A) Independente da exposição ao CO, o uso de animais CD39 no modelo de IRI gerou um aumento dos níveis da expressão de TNF- $\alpha$ no tecido renal. $\left({ }^{*} \mathrm{p}<0.05\right.$ vs controle e IRI+CO WT e ${ }^{* *} \mathrm{p}<0.05$ vs demais grupos). Já os níveis de cAMP, Per2 e EPO estavam reduzidos nos animais CD39KO - conforme observado nos painéis $\mathrm{B}, \mathrm{C}$ e $\mathrm{D}$, respectivamente. ${ }^{*} \mathrm{p}<0.05$ vs demais grupos.

Para averiguarmos se a proteção mediada pelo $\mathrm{CO}$ ocorria pela ligação da adenosina aos receptores Adora2, bloqueamos tais receptores com potentes antagonistas seletivos e realizamos a cirurgia de IRI, sendo que um grupo recebeu o tratamento com CO. Como é possível verificar na Figura 39, a falta de ligação da adenosina ao Adora2 levou a uma piora da função renal, um aumento do processo inflamatório, acompanhado de uma redução na expressão de Per2. Mais uma vez, o tratamento com $\mathrm{CO}$ não foi capaz de reverter tal quadro, indicando que o $\mathrm{CO}$ 
depende da ligação da adenosina aos receptores Adora2 para gerar uma resposta intracelular que levaria a uma recuperação tecidual mais rápida.

Figura 39 - A ligação de adenosina aos receptores Adora2 é importante para a proteção após exposição ao $\mathrm{CO}$.

A.

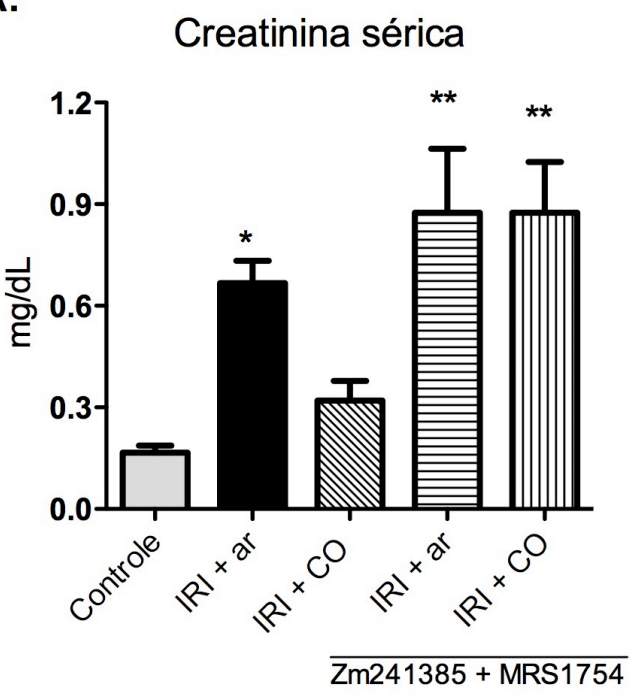

C.

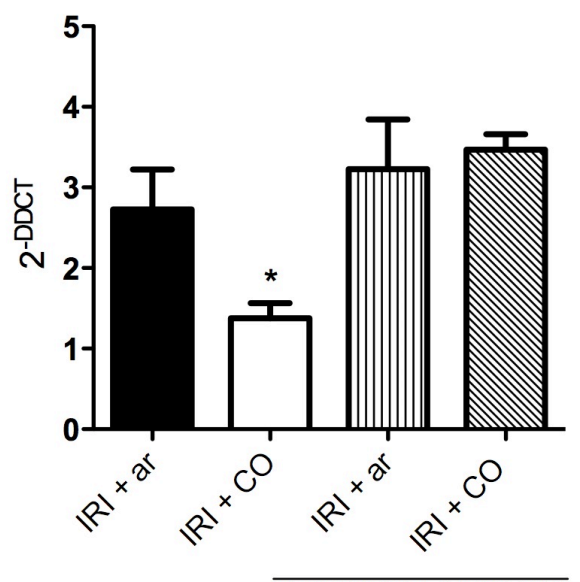

B.

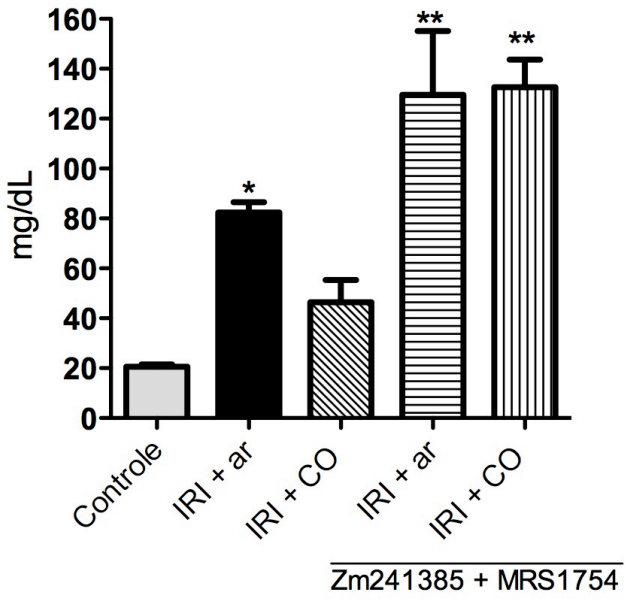

D.

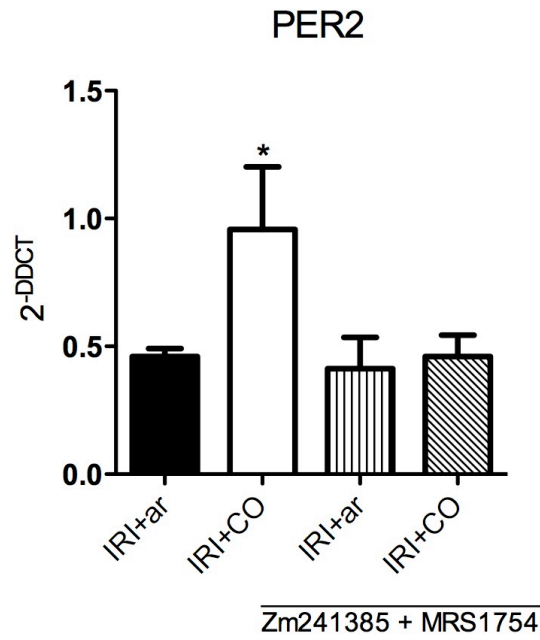

Animais tratados com antagonistas seletivos para Adora2a (Zm241385) e Adora2b (MRS1754) foram submetidos a IRI $\pm C O$. Os painéis A e B mostram os valores de creatinina e uréia séricas, respectivamente $\left({ }^{*} \mathrm{p}<0.05\right.$ vs controle e IRI+CO e ${ }^{* *} \mathrm{p}<0.05$ vs demais grupos). Nos painéis $C$ e D, avaliou-se a expressão gênica de TNF- $\alpha$ e Per2 nos grupos indicados, respectivamente. ${ }^{*} \mathrm{p}<0.05$ vs demais grupos). 


\subsection{O tratamento com CO gera uma mudança metabólica nas células renais}

A regeneração celular após o insulto isquêmico é favorecida pela presença de fontes de energia capazes de acelerar tal processo reparativo. Assim, a disponibilidade de ATP é crucial para que essa recuperação seja feita de forma eficiente.

Como mostrado na figura 40A, a presença de CO leva a um aumento dos níveis protéicos de PGC-1 $\alpha$, um dos principais marcadores de biogênese mitocondrial. Somado a esse fato, é possível verificar no painel D da mesma figura que as células que foram previamente expostas ao $\mathrm{CO}$ também exibem uma marcação mais forte para a presença de mitocôndrias. Esse maior número de mitocôndrias no grupo que recebeu $\mathrm{CO}$ poderia explicar a recuperação dos níveis de ATP e o aumento da quantidade de lactato após o protocolo de HR (Figuras 40, painéis B e C). Com mais energia dentro da célula, observamos que essas conseguem proliferar mais (Figura 40A - marcação para ERK), além de aumentar a sua viabilidade (Figura 41, painéis A e B) e manter o padrão normal do ciclo celular (Figura 41C). Tais dados nos sugerem que a presença de CO favorece uma recuperação mais rápida via regulação positiva da produção de ATP intracelular pelas mitocôndrias. 
Figura 40 - Células expostas ao CO apresentam uma mudança metabólica.

A.
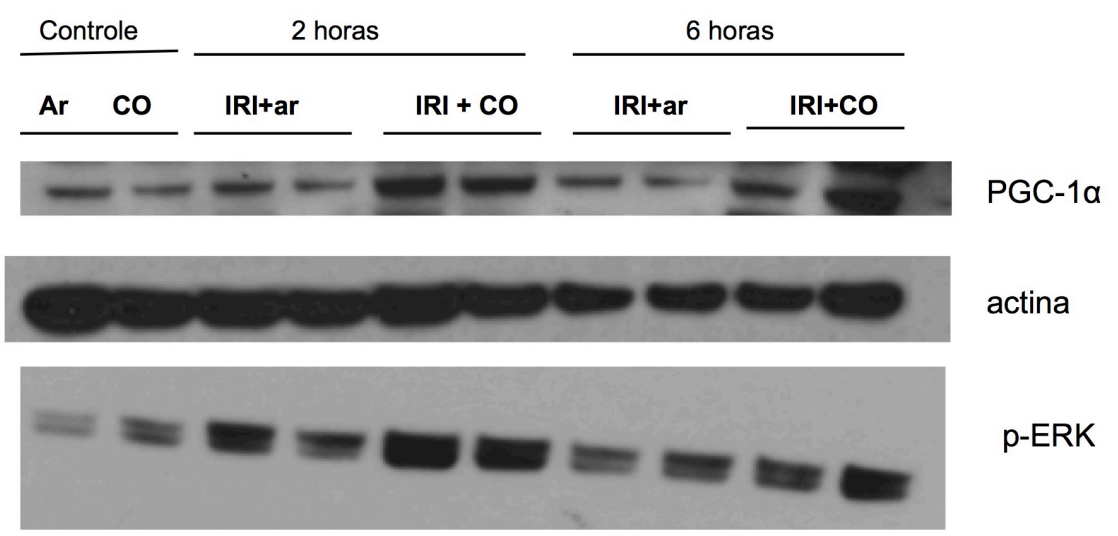

p-ERK

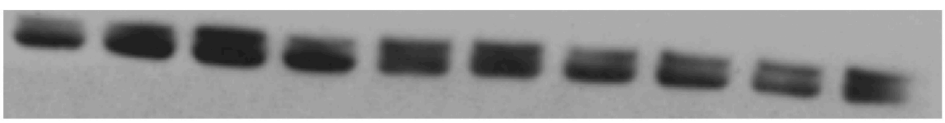

Total ERK

B.

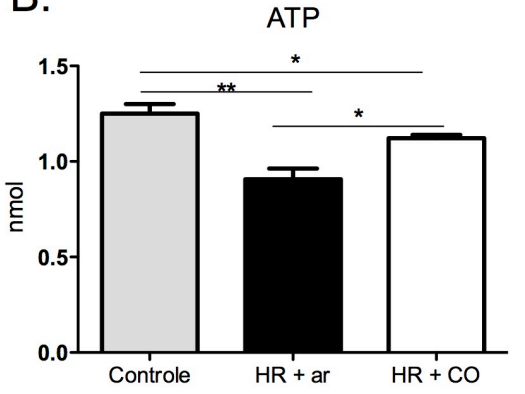

D.

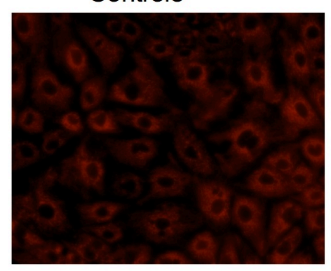

co

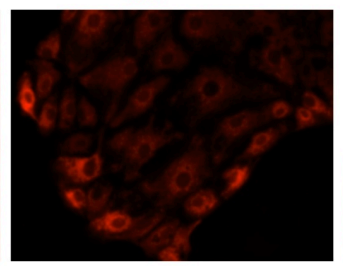

C.

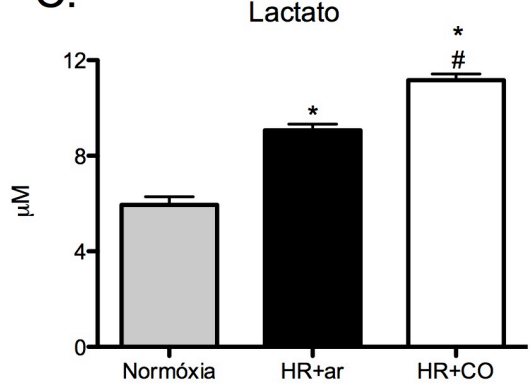

HR+ar
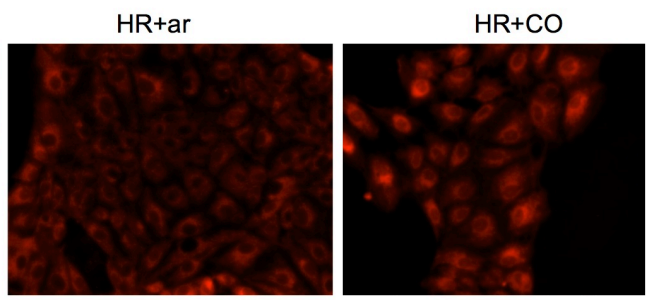

mitotracker

A) Representação da expressão protéica de PGC-1 $\alpha$, actina, p-ERK e ERK total, nos rins de animais submetidos a lesão isquêmica e que foram tratados ou não com CO. B) Dosagem de ATP intracelular de células submetidas a normóxia, ou HR $\pm \mathrm{CO}\left({ }^{*} \mathrm{p}<0.05\right.$ e $\left.{ }^{* *} \mathrm{p}<0,01\right)$. C) Dosagem de lactato intracelular nos mesmos grupos descritos anteriormente $\left({ }^{*} p<0.05\right.$ vs normóxia e \# p $<0.05$ vs HR+ar). Em D) Avaliação da presença de mitocôndrias nas células por imunofluorescência. 
Figura 41 - Exposição ao CO aumenta a viabilidade celular.

A.

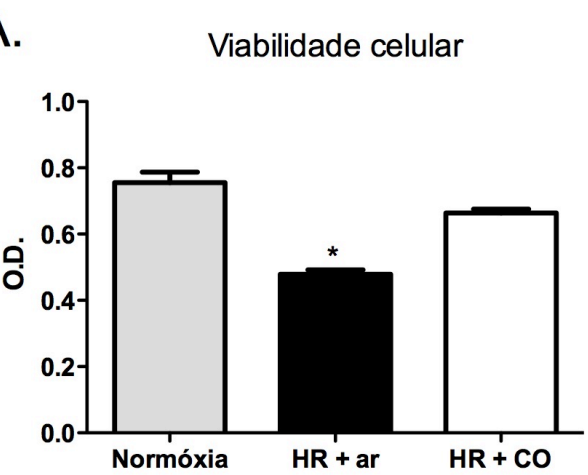

B. Células apoptóticas

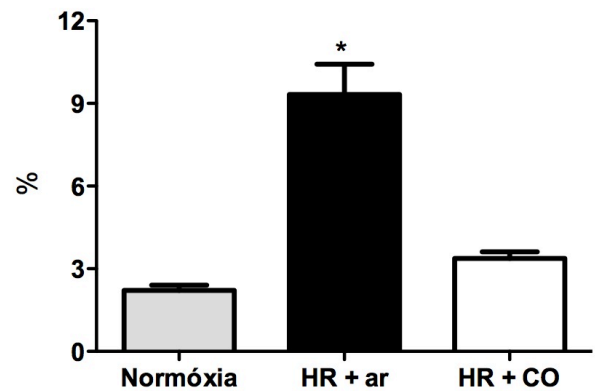

C.

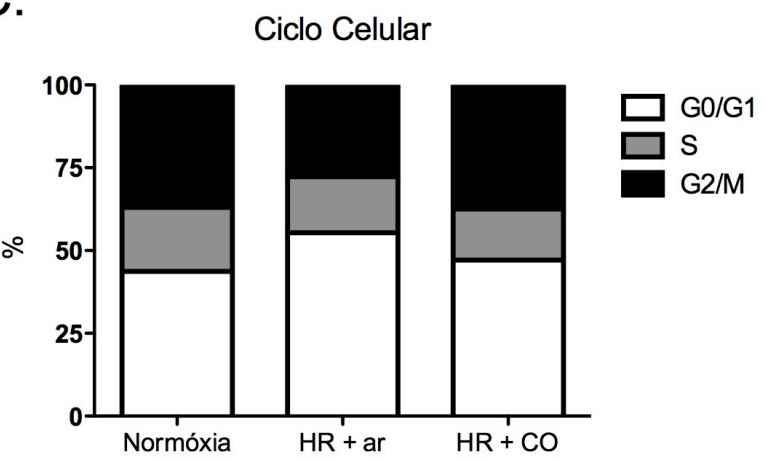

A quantidade de células viáveis/apoptóticas foi avaliada pelas técnicas de A) Violeta Cristal e B) Iodeto de Propídio, respectivamente. Em C, está representado o perfil do ciclo celular durante as condições de normóxia, $\mathrm{HR}+\mathrm{ar}$ e $\mathrm{HR}+\mathrm{CO}$. * p $<0.05$ vs normóxia e $\mathrm{HR}+\mathrm{CO}$. 
5 DISCUSSÃO 
A IRI renal é resultado de um desbalanço entre fatores que promoverão sobrevivência e funcionamento celular (por exemplo, genes citoprotetores e mecanismos de reparo celular) e fatores que geram efeitos deletérios no tecido lesado (por exemplo, disfunção circulatória e ativação do sistema imune nos rins). Em linhas gerais, a prevalência de fatores do último grupo determina a ocorrência do insulto renal. Além disso, já foi descrito que a resposta das células tubulares renais depende da intensidade e do período da isquemia, e muitas mudanças como proliferação, diferenciação, dediferenciação, perda da polaridade e morte celular são relevantes durante a lesão de IRI [144]. Assim, uma modulação de todo esse processo poderá resultar em um benefício para o paciente.

Em nosso estudo, verificamos que a indução do sistema da HO-1, formado pela enzima e seus subprodutos, promoveu um importante efeito protetor na lesão renal isquêmica. Tal efeito se traduziu por menor inflamação, redução do estresse oxidativo, e diminuição da hipóxia. Como consequência, houve uma atenuação do ERS, levando - em um momento final - a uma melhora da função renal.

Uma série de condições seria responsável pela indução do ERS. Por exemplo, durante a inflamação, há um aumento maciço da síntese de proteínas (citocinas, quimiocinas, anticorpos, etc), gerando assim uma grande dificuldade para o retículo endoplasmático em empacotar corretamente essas proteínas recentemente produzidas - dando-se início assim ao ERS. Por sua vez, o próprio ERS exacerba o processo inflamatório, através da ativação de NF-kB [145-148]. Já o estresse oxidativo, o qual é amplificado pela inflamação ou hipóxia, induz o ERS pelo acúmulo de espécies reativas de oxigênio, e vice versa[149]. Por fim, a hipóxia leva a um consumo do conteúdo energético celular, o qual poderia ser usado para o empacotamento protéico, acumulando assim proteínas mal empacotadas, e como consequência, ativando as vias do ERS [150].

Sabe-se que dependendo da duração e da intensidade do estímulo, o desfecho da ativação do ERS pode ser completamente diferente. Caso o insulto seja de curta duração ou de baixa intensidade, há uma resposta celular protetora (como, por 
exemplo, indução do processo de autofagia, modulação de Nrf2 e ativação de HIF-

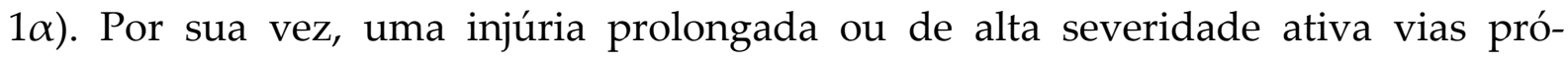
apoptóticas, aumentando a morte celular e consequente exacerbação da lesão [151]. Um bom exemplo nesse caso é o pré-condicionamento isquêmico, um insulto de curta duração que ativa vias de pró-sobrevivência da UPR. Por sua vez, a lesão isquêmica tradicional, de maior duração, gera uma injúria suficiente para provocar a ativação das vias pró-apoptóticas. Além disso, já foi demonstrado que o prétratamento com uma dose subtóxica de indutor do ERS é protetora num modelo experimental de glomerulonefrite mesangioproliferativa [40].

Estudos têm demonstrado que a lesão de IRI é capaz de ativar as vias do ERS, seja pelo aumento da expressão da própria BiP [152], ou pela ativação das diferentes vias da UPR [153], confirmando assim os nossos dados. A via da UPR está envolvida na resposta do rim a injúria isquêmica aguda e tem um papel complexo na regulação da adaptação celular a condições de estresse, bem como promovendo morte celular $[29,154]$. Estudos recentes têm mostrado que a UPR é responsável pela inibição da síntese de proteínas que ocorre após a IRI renal e participa do início da injúria tubular $[153,155]$. Ainda, Fougeray e colaboradores demonstraram que um episódio isquêmico promove ERS in vitro, in vivo e em biópsias renais humanas coletadas previamente à implantação renal. Eles mostraram que a UPR está envolvida na montagem de uma resposta inflamatória tubular que poderia contribuir para o microambiente pró-inflamatório que, por sua vez, colaboraria para a ativação da resposta imune adaptativa [140].

De forma interessante, ao analisarmos, no nosso modelo in vivo, a cinética de expressão dos dois marcadores de ERS, BiP e CHOP, podemos observar que nos primeiros momentos há um aumento da expressão da $\mathrm{BiP}$, que representa a via de retorno à homeostase celular. Com o passar do tempo, essa reduz e a molécula da via apoptótica CHOP passa a ter maior expressão, coincidindo com o momento em que há aumento da lesão tecidual, verificados por maior disfunção renal e índices elevados de necrose tubular aguda [156]. 
Em relação ao fato das células em situação de estresse estacionar na fase G0/G1 do ciclo celular, Brewer e Diehl mostraram que células tratadas com tunicamicina perdem a capacidade de ativar a Ciclina D1, um regulador positivo do ciclo celular. Esta ciclina, em conjunto com outras ciclinas do tipo D, parece ser especialmente importante para a progressão da fase G1 do ciclo celular. Assim, ocorre um aumento do número de células nessa fase, corroborando nossos achados. Ainda, a via de PERK da UPR parece estar associada a esse processo, uma vez que o mesmo fenômeno foi observado quando as células, sem estímulo de estresse, passaram a superexpressar essa molécula [157]. Além disso, foi demonstrado que esse aumento do número de células na fase G1 é proporcional ao tempo de estresse do retículo o qual a célula foi submetida (nesse caso o ERS foi induzido tanto farmacologicamente pela adição de tunicamicina ao meio, quanto pela redução drástica da quantidade de soro fetal disponível). A evidência de que o ERS de fato ocorreu é baseado no aumento tempo-dependente dos níveis de BiP e CHOP [158].

Uma vez que já tínhamos conhecimento dos mecanismos desencadeadores da lesão renal, achamos que seria interessante utilizar alguma alternativa terapêutica que pudesse prevenir o desenvolvimento da doença. Assim, surgiu a possibilidade de estudarmos mais profundamente o sistema da HO-1, formado por essa enzima e seus subprodutos. Resolvemos dar destaque, dentre esse último grupo, ao CO, uma molécula classicamente tida como tóxica, mas que vem se mostrando como um importante mediador da proteção e recuperação celular.

Trabalhos anteriores do nosso grupo já demonstravam que a regulação positiva da HO-1 promovia um efeito benéfico. Assim, observamos que, em diferentes modelos experimentais de doenças renais agudas ou crônicas, o aumento da expressão da HO-1, seja por indutores diretos - como Cobalto de Protoporfirina IX ou Hemin - ou por indutores indiretos - como células tronco mesenquimais, Tacrolimus, ou Indometacina - gerava um quadro evidentemente favorável à resolução da injúria $[63,139,156,159-161]$. 
O papel da HO-1 como um agente protetor na IRI renal já foi descrito na literatura, tendo sido inclusive assunto de uma revisão escrita em 2010 [162]. Por exemplo, um estudo demonstrou que o tratamento com um agonista do receptor GLP-1R (Glucagon-like peptide-1 receptor) antes da IRI renal promoveu a indução de HO-1, resultando em melhora da função renal, com índices de lesão histológica, apoptose e marcação para macrófagos muito menos severos do que animais não tratados[163]. Além disso, um outro trabalho demonstrou que o précondicionamento isquêmico induziu a expressão de HO-1, promovendo uma redução dos níveis séricos de creatinina, da morte celular e de marcadores inflamatórios [164].

Recentemente, um trabalho sugeriu que a HO-1, pelo fato de ser uma proteína de resposta ao estresse, poderia ser um bom marcador de LRA, uma vez que pacientes nessas condições exibiam um aumento da expressão sérica e urinária dessa enzima, o que não foi observado em pacientes críticos sem LRA ou em pacientes com doença renal crônica. Os autores reforçam o conceito de que tal aumento da HO-1 seria um mecanismo intrínseco de tentar reduzir os danos causados pelo insulto e promover um retorno à homeostase celular [165].

Por fim, já foi também demonstrado que a modulação de células do sistema imune pela HO-1 parece ser outro fator favorável à resolução da IRI renal. Um trabalho demonstrou que o tratamento dos doadores do órgão com indutores da HO1 resultou em uma proteção funcional e redução da expressão de imunoproteassomos, do complexo de histocompatibilidade principal de classe II (MHC II) e moléculas co-estimulatórias no baço dos receptores, sugerindo que a HO1 agiria inibindo a ativação de células dendríticas derivadas dos doadores [166]. Outro estudo indicou que a administração de macrófagos que superexpressavam HO-1, 20 minutos após a IRI, levava a uma melhora da função renal e um perfil antiinflamatório [167]. Ainda, Ferenbach e colaboradores demostraram, de uma forma elegante, que animais com idade avançada exibem uma redução da expressão de HO-1 após a IRI renal, o que se correlaciona com um aumento significativo da 
disfunção renal e da necrose tubular aguda, quando comparados com animais mais novos submetidos ao mesmo procedimento. Por sua vez, a indução da HO-1 nesses animais envelhecidos reverteu esse fenótipo. Os autores ainda salientam que esse efeito ocorreu pelo aumento da HO-1 em macrófagos, uma vez que a indução da HO-1 após a depleção desse tipo celular resultou em perda da proteção observada [168].

Em relação ao $\mathrm{CO}$, alguns trabalhos já demonstraram que o aumento da disponibilidade desse gás é benéfico na LRA. Vera e colaboradores mostraram que animais pré-tratados com CORM-3, e que posteriormente foram submetidos à lesão de IRI apresentaram menor número de túbulos lesados, uma redução significativa dos valores de creatinina sérica e um aumento da expressão de HO-1 [169]. Ainda, um trabalho evidenciou que a exposição ao CO reduziu de forma drástica a hipóxia renal. Nesse estudo, os autores mostraram que imediatamente após a reperfusão não há marcação para hipóxia no grupo tratado, contrastando de forma evidente com o grupo que recebeu somente ar. Além disso, o mesmo trabalho demonstrou que, desde momentos precoces, o tratamento com CO levava a uma modulação da resposta tecidual à lesão isquêmica, via regulação positiva de moléculas protetoras e menor expressão de agentes deletérios [170].

Além disso, foi demonstrado num modelo de transplante renal em suínos que o tratamento dos receptores do órgão com $\mathrm{CO}$ durante a cirurgia por 1 hora restaurava a função renal de maneira mais rápida do que no grupo de animais nãotratados, além de reduzir a necrose tubular aguda, apoptose celular e expressão de moléculas pró-inflamatórias [171]. No mesmo modelo de transplante renal, um estudo demonstrou que o tratamento dos doadores do órgão com CORM-2 levou a uma sobrevida de 100\% dos animais e normalização dos níveis de creatinina sérica, enquanto que os animais não tratados morreram 3 dias após a cirurgia, devido a uremia[172]. Tais dados corroboram nossos resultados, mostrando que um tratamento que aumentaria os níveis de $\mathrm{HO}-1 / \mathrm{CO}$ pode promover uma melhora funcional ao rim após um episódio de lesão isquêmica. 
Conforme observado em nossos resultados, a presença de $\mathrm{HO}-1$ ou $\mathrm{CO}$ parece atenuar o processo de ERS. Apesar da indução de HO-1 já ter sido descrita como uma das consequências da ativação da via da UPR, a modulação desse processo pela enzima ainda não está completamente esclarecida. Um estudo recente indicou que o aumento de HO-1, num modelo de IRI hepática, promovia uma melhora funcional do órgão e menor expressão de $\mathrm{CHOP}$, o que resultava numa redução da morte celular [173]. Porém, os mecanismos pelos quais essa proteção acontecia ainda não estavam claros. Nesse sentido, alguns trabalhos do grupo do professor Chung foram essenciais para um melhor entendimento desse processo. Utilizando células endoteliais, um dos estudos demonstrou que o tratamento com $\mathrm{CO}$ induziu a expressão de HO-1 nessas células, via modulação exclusiva da PERK, a qual preveniu a morte celular induzida por CHOP, após o estímulo com drogas indutoras de ERS - tapsigargina, tunicamicina e homocisteína. De forma interessante, eles indicam que essa proteção foi mediada por dois mecanismos: via ativação de p38 e da sinalização de Nrf2/HO-1[174]. Posteriormente, o mesmo grupo mostrou - em macrófagos - que na presença da HO-1 há conversão da sinalização pró-ERS em sinalização de sobrevida por influência na regulação e integridade de mitocôndrias, via ativação de fatores de transcrição e de integridade funcional de DNA mitocondrial, essenciais para a biogênese dessa organela [175].

Além disso, o papel citoprotetor do CO em relação ao ERS já foi avaliado em outras situações. Previamente, foi demonstrado que ativação do ERS leva a produção das chamadas proteínas de fase aguda, componente amilóide P (CAP) e proteína C reativa (PCR) [27]. Baseado nessa informação, Chung e colaboradores mostraram que animais que receberam tunicamicina e foram tratados com CORM exibiam menores valores séricos de CAP e PCR, acompanhados de menor expressão gênica de marcadores do ERS. Ao estimularem as células previamente tratadas com CORM, com diferentes indutores de ERS, os pesquisadores confirmaram os dados in vivo, mostrando uma redução da expressão de diferentes marcadores de ERS. Interessantemente, não houve inibição da via da PERK. Ainda, foi demonstrado que 
o estímulo pró-inflamatório por IL-6 induzia a expressão gênica de PCR, fato atenuado pelo tratamento com CORM [176]. Assim, podemos inferir que tais informações confirmam nossos dados e mostram que os mecanismos pelos quais a HO-1 modula o ERS não parecem ser tecido-específicos, uma vez que há o compartilhamento de uma série de fatores. É interessante ressaltar que, no tecido renal, nenhuma evidência até então tinha sido mostrada relacionando a inibição do ERS frente ao estímulo com um indutor da HO-1.

É válido destacar também que um dos principais eventos observados nesse trabalho foi a regulação negativa do processo inflamatório na presença de HO-1/CO. Nesse sentido, a HO-1 parece agir como um regulador negativo do processo inflamatório, reduzindo o recrutamento e amplificação da resposta imune.

Além disso, a regulação positiva dessa enzima resulta em expressão reduzida de moléculas de adesão, recrutamento de leucócitos e menor atividade da via do NF$\mathrm{kB}[177,178]$.

Dentre esses fatores citados no final do parágrafo anterior, podemos citar o PPAR- $\gamma$, cuja expressão se mostrou aumentada nas células tratadas com Hemin, se correlacionando com um perfil benéfico e aumento da viabilidade celular. Os efeitos protetores da ativação de PPAR- $\gamma$ nas doenças renais já foram largamente descritos. Dentre eles, destacam-se: 1) atenuação da nefropatia diabética - por aumento da sensibilidade sistêmica à insulina e redução da resistência à insulina das células renais, 2) melhora do controle da pressão arterial, 3) redução da inflamação renal e do estresse oxidativo, e 4) restauração da sinalização renal de adiponectina [179]. Além disso, a relação entre o ERS e o PPAR- $\gamma$ também já foi, pelo menos em parte, esclarecido. Um trabalho mostrou que, após a ativação de ERS e subsequente produção de CHOP, há um aumento da expressão de NF- $\kappa \mathrm{B}$, exacerbando o processo inflamatório. E, segundo os autores, essa ativação da via do NF- $\kappa B$ ocorre pela repressão de PPAR- $\gamma$, mediada pela própria CHOP [180]. Tais informações corroboram nossos dados e indicam, mais uma vez, que a atenuação do ERS gera uma série de sinais protetores, que tendem a favorecer a recuperação da célula ou 
tecido lesão.

Um dado interessante que obtivemos foi o leve aumento da ROS de origem mitocondrial nos grupos tratados com Hemin. Tal efeito, que a princípio pode parecer incoerente com os demais resultados, mas já foi evidenciado por outros grupos, os quais sugeriram um efeito dependente de CO. Zuckerbraun e colaboradores demonstraram que esse gás age via inibição da citocromo c oxidase, promovendo a geração de baixos níveis de ROS mitocondrial, que por sua vez mediaria uma sinalização adaptativa protetora, mantendo os níveis de ATP celular e aumentando o potencial de membrana mitocondrial [181]. Em complemento a essas informações, outro trabalho confirmou que tal efeito é relacionado à interação COcitocromo c oxidase e ainda evidenciou que essa produção de ROS mitocondrial seria importante para gerar um efeito favorável à biogênese mitocondrial [182]

A habilidade da HO-1 em suprimir o processo inflamatório renal já foi descrita em um trabalho recente do nosso grupo, que mostrou a supressão da produção de TNF- $\alpha$, IL-6 e IL-1 $\beta$, com concomitante aumento da expressão de IL-10 após o tratamento com Hemin [63]. É interessante destacar também que o aumento de IL-10 parece ser diretamente relacionado com a atividade HO-1. Experimentos in vivo e in vitro indicaram uma perda do efeito supressor da IL-10 sobre a produção de TNF- $\alpha$ induzida por LPS após inibição da HO-1, indicando que tal enzima estaria downstream à IL-10. Os autores sugerem o envolvimento do subproduto CO nessa interação HO-1/IL-10 e tal efeito imunossupressor parece ser mediado pela ativação de p38 [183]. Somado a esse fato, outro grupo destacou que a produção de IL-10 seria uma consequência da ativação de $\mathrm{HO}-1$, gerando assim uma alça de amplificação. $\mathrm{O}$ mecanismo exato dessa via parece ser o seguinte: o $\mathrm{CO}$, liberado pela $\mathrm{HO}-1$, promove a ligação de uma série de fatores de transcrição (Nrf2, GABPA e MEF2) à região promotora do gene de IL-10, além de promover a ligação de NRF-1 e MEF2 ao promotor do antagonista do receptor de IL-1 (IL-1ra). Experimentos realizados com hepatócitos ou macrófagos mostraram que o silenciamento gênico de Nrf2 ou Hmox1 bloqueia a regulação positiva de IL-10 e IL-1Ra nessas células [184]. 
Por sua vez, o papel da p38 na regulação do processo inflamatório - fato observado nesse trabalho - vem ganhando cada vez mais destaque na literatura científica recente. Falando especificamente do modelo de lesão isquêmica, um trabalho demonstrou que o pré-condicionamento isquêmico é um importante fator de proteção à células submetidas ao modelo de hipóxia e reoxigenação (HR). Nesse caso, o pré-condicionamento reduziu drasticamente a presença de marcadores do ERS e, consequentemente, houve uma diminuição da morte celular induzida pelo insulto isquêmico, acompanhado de um aumento de uma sinalização antiapoptótica. Tal condição parece ter sido mediada pela p38, uma vez que o uso de seu inibidor (SB203580) reverteu todo quadro protetor conferido pelo précondicionamento [185].

Além disso, uma série de outros trabalhos têm relacionado a p38 com a HO-1 e seus subprodutos. O primeiro trabalho que demonstrou a ligação entre o sistema da HO-1 e a p38 foi publicado por Otterbein e colaboradores, no início dos anos 2000. Os autores demonstram que em macrófagos expostos ao $\mathrm{CO}$, há um aumento da fosforilação de p38, gerando um efeito anti-inflamatório nessas células, com diminuição da produção de TNF- $\alpha$ e aumento de IL-10 [186]. O mesmo grupo demonstrou posteriormente que a sinalização CO-p38 era importante também para gerar um efeito anti-apoptótico, no modelo de IRI pulmonar [187]. Seguindo essa linha, outro trabalho demonstrou que macrófagos que foram tratados com Hemin se tornavam mais imunossupressor, e essa propriedade era perdida quando os mesmos eram tratados com o inibidor da p38, 1 hora antes do estímulo com o indutor da HO1 [188].

Ainda, o uso de outras drogas que não são classicamente definidas como indutoras de HO-1 - mas que provavelmente regulam a expressão dessa molécula também parecem exercer seus efeitos protetores via ativação da p38. Nesse sentido, Chen e colaboradores evidenciaram que, em cardiomiócitos pré-tratadas com Lipoxina A4, e submetidos ao protocolo de HR, há uma ativação de p38, com subsequente translocação nuclear de Nrf2 e aumento da expressão de HO-1, 
conferindo assim um aumento da viabilidade celular [189]. Além disso, um trabalho recente demonstrou, num modelo de isquemia e reperfusão cardíaca, que o prétratamento com dobutamina induziu a expressão de HO-1, e atenuou a injúria cardíaca, com menor estresse oxidativo e redução da ativação de NF-kB. Esses efeitos benéficos parecem ser dependentes de PI3K/AKT e p38, uma vez que a inibição dessas vias levou a perda da proteção observada [190]. Por fim, foi demonstrado que o tratamento com niacina atenua a inflamação vascular em modelos in vivo e in vitro, sendo que tal efeito ocorre também pela ativação de p38, que agiria no Nrf2 e, consequentemente, induziria a expressão de HO-1 [191]. Tais dados corroboram nossos resultados, uma vez que mostram que tanto a via de AKT quanto a de p38 são importantes para que a HO-1 exerça seu papel.

Já a ação anti-inflamatória do CO também está bem estabelecida, tendo sido descrita por diferentes grupos. Estudos mostraram que, em cultura celular, o tratamento com CO inibiu a apoptose induzida por TNF- $\alpha$ em fibroblastos murinos e em células endoteliais [192,193]. Ainda, a presença de CO foi capaz de reduzir a produção de TNF- $\alpha$, IL-1 $\beta$ e MIP-1 (do inglês, macrophage inflammatory protein-1) na presença de LPS [194]. Por sua vez, a produção da citocina anti-inflamatória IL-10 estava aumentada após tratamento com CO [186].

Além disso, observamos em nosso estudo que após o aumento da disponibilidade de $\mathrm{CO}$ há um menor número de macrófagos infiltrantes e ainda uma mudança de seu perfil, tendendo a uma população mais regulatória. Já foi bem descrito que os macrófagos representam uma das principais células mediadoras da lesão renal aguda, principalmente via produção de moléculas pró-inflamatórias e ativadoras de linfócitos [195].

A presença de um ambiente inflamatório estimularia a migração de um subtipo de macrófago conhecido como M1, o qual já foi descrito como importante para maior produção de TNF- $\alpha$. Essa citocina, além de ter um efeito autócrino/parácrino nos próprios macrófagos, promovendo ativação desses, induz a apoptose/necrose de células do parênquima renal, como as células endoteliais, 
células tubulares e podócitos [196-198]. Além disso, a necrose celular que ocorre na LRA cria um microambiente intra-renal rico em ligantes endógenos (conhecidos como DAMPs), que por sua vez promovem diferenciação de monócitos circulantes em macrófagos pró-inflamatórios, gerando uma alça de amplificação do processo inflamatório e da perda de células renais [199].

Por sua vez, mecanismos de reparo tecidual costumam ser ativados para regular o processo inflamatório, através da liberação de moléculas como IL-10 e TGF$\beta$ [200]. Esse microambiente dominado por citocinas anti-inflamatórias, além de células apoptóticas, podem inibir os macrófagos M1 e diretamente promover a diferenciação dos monócitos em macrófagos anti-inflamatórios, ou M2 [201].

É interessante observar que esses macrófagos têm a capacidade de amplificar os sinais anti-inflamatórios da mesma maneira que os macrófagos M1 amplificam o ambiente pró-inflamatório. Assim, macrófagos M2 reduzem muitos fatores tóxicos e pró-apoptóticos, que limitam a eficiência do reparo tecidual. Assim, se a inflamação ocorre por um período curto e transiente, como no caso de uma toxicidade leve a moderada ou na lesão de IRI, os macrófagos M2 irão aumentar a capacidade de regeneração tubular [199]. Assim, podemos concluir que a mudança do perfil de macrófagos M1 para M2 contribuiu para um menor dano ao tecido renal, com consequente melhora da inflamação e da função renal.

Outro fator observado por nós nesse trabalho foi uma modulação da sinalização purinérgica. Após o tratamento com CO, uma maior disponibilidade de adenosina no espaço extracelular e sua consequente ligação aos receptores de adenosina do tipo 2 promoveram uma ativação de vias intracelulares citoprotetoras, gerado assim um importante favorecimento à recuperação celular.

Devido a suas características físico-químicas, o CO pode facilmente atravessar a membrana plasmática e agir como um mensageiro intracelular. O fato do CD39 ser regulado positivamente por esse gás parece ser mais uma evidência dessa constatação. A regulação gênica do CD39 parece ser exercida por um fator de transcrição denominado Sp1, membro de uma família de fatores de transcrição 
denominada $\mathrm{Sp} / \mathrm{XKLF}$, além de ser um regulador gênico de outras importantes moléculas, como VEGF e Cistationina- $\beta$-sintase [202]. Além disso, já foi descrito que a lesão isquêmica leva a uma redução da expressão de Sp1 no tecido renal[203]. Porém, um estudo demonstrou que o tratamento com CO leva a um aumento da expressão de Sp1 e a superexpressão de uma forma mutante desse fator impossibilita a sua atividade transcricional induzida pelo CO [204].

Além disso, outra condição contribui de maneira importante para a maior expressão de CD39; Liao e colaboradores mostraram que a expressão de CD39 é também regulada pelo aumento dos níveis citoplasmáticos de cAMP, que envolve a ativação das seguintes vias PKA/CREB, PKA/PI3K/ATF2, e PKA/ERK/ATF2. Pelo fato de também termos observado um aumento de cAMP nos rins de nossos animais tratados, achamos que é sensato pensar que a regulação de CD39 também seja feita por via esse segundo mensageiro [205].

O papel protetor da adenosina na lesão renal foi averiguado em um trabalho no qual os autores demonstraram que a administração de adenosina externa protegia as células renais dos eventos deletérios causados pelo modelo de hipóxia/reoxigenação. No mesmo estudo, foi demonstrado que tal procedimento preservou o conteúdo intracelular de ATP, durante o evento isquêmico[206]. Ainda, o aumento da expressão de receptores Adora2 pelo CO já foi demonstrada em macrófagos. Tal estudo indicou que a maior presença desses receptores na membrana plasmática promoveu uma mudança na sinalização intracelular, alterando a célula para um perfil mais tolerogênico, com menor produção de TNF- $\alpha$ [142].

Vale a pena destacar ainda o trabalho realizado por Ribeiro e colaboradores onde mostraram que as células tubulares renais possuem na sua superfície uma ectonucleotidase com propriedades enzimáticas com alta similaridade à CD39. Além disso, os autores relatam que durante uma lesão isquêmica há uma redução de até $71 \%$ na capacidade enzimática de converter. Os maiores níveis de cAMP após a exposição ao CO agiriam como importantes mediadores de proteção nesse modelo. 
Segundo Erckle e colaboradores, esse aumento seria diretamente responsável pela maior produção de Per2, molécula chave na estabilização de HIF-1 $\alpha$ [141]. Porém, provavelmente a proteção observada também seria obtida por outro mecanismo. Uma das moléculas intimamente relacionadas ao aumento de cAMP é a proteína CREB. Após ser fosforilada, tal molécula parece inibir diretamente a ativação de NF$\kappa B$, portanto, limitando a resposta pró-inflamatória. Além disso, a ativação de CREB é extremamente importante para a geração e manutenção de células $T$ regulatórias [207].

Ainda, podemos também considerar o papel de HIF-1 $\alpha$, como importante mediador da proteção observada após o tratamento com CO. Quando o suprimento sanguíneo para um tecido é inadequado, muitas células trocam o metabolismo aeróbico para o anaeróbico, tornando a fermentação anaeróbica o modo primário de produção de energia e ativando os fatores de transcrição chamados conhecidos como HIF [208]. O papel protetor de HIF-1 $\alpha$ na isquemia renal foi descrito anteriormente. Segundo os autores, a presença desse fator de transcrição seria importante para uma recuperação mais rápida do tecido lesado[209]. De fato, Hill e colaboradores mostraram que após realizar a cirurgia de IRI renal em animais heterozigotos para HIF- $1 \alpha$, houve um agravamento significante da severidade da disfunção renal. Em contrapartida, o uso de substâncias que aumentaram a meia-vida de HIF-1 $\alpha$ nas células, levou a uma importante resposta protetora, com melhora da função renal e redução do processo inflamatório [210].

Além disso, um estudo mostrou que ao expor macrófagos ao tratamento com $\mathrm{CO}$, houve uma maior estabilização de HIF-1 $1 \alpha$. O aumento dessa molécula foi correlacionado a maior produção de TGF- $\beta$, uma importante citocina antiinflamatória. Para confirmar tal hipótese, os autores bloquearam a expressão de HIF$1 \alpha$, através de RNA de interferência ou pelo uso de macrófagos deficientes de HIF$1 \alpha$, e observaram que as células deixaram de produzir TGF- $\beta$ e passaram a ser mais pró-inflamatórias. Interessantemente, um dos mecanismos que parece estar envolvido nessa proteção pelo HIF-1 $\alpha$ após o tratamento com $\mathrm{CO}$ seria o aumento 
rápido e transitório de ROS em um momento inicial após a exposição ao gás, numa condição muito semelhante a um pré-condicionamento. Ainda, nesse mesmo trabalho, um modelo in vivo de IRI pulmonar confirmou o mecanismo protetor do CO mediado por HIF-1 $\alpha$ [211].

É válido também destacar que a importância de moléculas do ciclo circadiano na regulação do sistema imune foi descrito recentemente. Tal modulação, intitulada de "imunocronoterapia", está sendo apontada por sua capacidade em ajudar na recuperação tecidual e na limpeza da circulação de elementos potencialmente danosos à célula [212]. Tais dados da literatura confirmam nossos achados e indicam que o CO medeia importantes vias citoprotetoras, possibilitando uma melhor adaptação ao insulto e promovendo uma rápida recuperação.

Vários estudos vêm tentando desvendar o papel citoprotetor da EPO em modelos de lesão renal. Nesse sentido, diferentes perspectivas vêm sendo dadas para melhor elucidar essa questão. Levando em consideração que os rins são particularmente sensíveis à altos níveis de glicose, um trabalho destacou o papel de EPO na prevenção da disfunção recorrente ao modelo de IRI durante uma hiperglicemia transitória. Os autores evidenciaram que apesar de não conseguir prevenir a necrose tubular, o tratamento com EPO foi capaz de atenuar a apoptose e a disfunção glomerular [213].

Entretanto, o mecanismo melhor descrito para justificar a ação benéfica da EPO nas lesões renais é por seu efeito anti-inflamatório. Em um modelo de lesão renal aguda subsequente à sepse, o tratamento com EPO levou a uma menor expressão renal de TLR4, NF- $\mathrm{B}$ e CD68, quando comparado ao grupo não tratado. Em contrapartida, os níveis de EPOR estavam aumentados após o tratamento. Além disso, houve menor expressão sérica de moléculas pró-inflamatórias no grupo que recebeu EPO [214]. Falando mais especificamente de IRI renal e EPO, Hu e colaboradores demonstraram que o tratamento com EPO antes da lesão isquêmica promoveu uma melhora da função renal, com menos necrose tubular e redução do índice de lesão histológica. Além disso, o número de neutrófilos estava 
significantemente diminuído nos animais tratados, acompanhado de menor expressão de citocinas e quimiocinas pró-inflamatórias. Por fim, o tratamento com EPO levou a uma menor translocação nuclear do NF- $\kappa B$ [215].

Vale a pena também registrar que vários trabalhos já demonstraram que a EPO regula também a expressão de HO-1. Um trabalho recente demonstrou que o uso de EPO no modelo de encefalomielite autoimune experimental (EAE) levou a um aumento da expressão de HO-1 e modulação da imunidade adaptativa, levando a uma repressão da resposta inflamatória[216]. Já outro estudo mostrou que o aumento da expressão de HO-1 pela EPO ocorre através da ativação das vias PI3K, MAPK, e Nrf2 [217]. Por fim, Burger e colaboradores mostraram que a regulação positiva de HO-1 mediada por EPO era responsável pela redução da apoptose de cardiomiócitos submetidos à IRI. Para provar tal hipótese, os autores observaram que a proteção à apoptose era perdida ao realizarem a lesão isquêmica após o bloqueio farmacológico ou com animais nocautes para $\mathrm{HO}-1$ [218].

Interessante, parece que ambas as moléculas (HO-1 e EPO) se regulam. Provavelmente a presença de uma promove um aumento da expressão da outra, gerando uma importante alça de amplificação citoprotetora.

Já a disfunção mitocondrial é um mediador de uma série de insultos celulares e um elemento comum na iniciação de várias doenças. A importância da biogênese mitocondrial se reflete na sua habilidade de aumentar algumas vias metabólicas, como oxidação de ácidos graxos, além de elevar os mecanismos de defesa antioxidantes, atenuando lesões provenientes do envelhecimento, hipóxia tecidual, excesso de glicose ou ácidos graxos, os quais contribuem para a patogênese de lesões renais agudas e crônicas [219]. Um trabalho publicado recentemente indicou que a utilização de compostos que venham a promover um aumento da capacidade de biogênese mitocondrial na célula está cada vez mais em evidência e pode vir a ser um promissor alvo terapêutico no futuro [220].

Especificamente falando de doenças renais, Tran e colaboradores mostraram que durante uma lesão renal aguda há uma importante disfunção mitocondrial e que 
a superexpressão de PGC-1 $\alpha$ levou a uma atenuação da insuficiência renal. Por outro lado, o uso de animais PGC-1 $\alpha$ KO promoveu uma piora persistente da função renal após um insulto agudo [221].

Já o papel do sistema da HO-1/CO nessa modulação da biogênese mitocondrial pode ser explicado pelo fato de que o suprimento energético celular é protegido de condições que causam danos a mitocôndrias por um programa transcricional induzido de biogênese mitocondrial que opera em grande parte via sinais redox envolvendo os sistemas da óxido nítrico sintase e HO-1/CO. Tais eventos redox estimulam atividades coordenadas de inúmeros fatores de transcrição multifuncionais e cofatores envolvidos na eliminação de mitocôndrias defeituosas e expressão de genes anti-oxidantes e imunorreguladores [222].

Uma vez que um tecido lesado é capaz de recuperar sua capacidade energética, ele passa a lançar mão dessa maior quantidade de ATP para se regenerar. Nesse momento, a proliferação de células viáveis é crucial para a completa recuperação desse tecido. A importância da proliferação celular durante um evento de LRA foi destacada por Bonventre e Yang em uma revisão publicada no periódico Journal of Clinical Investigation [209]. Nele, os autores salientam que a fase de proliferação e diferenciação celular é um evento chave que pode determinar o destino da doença, remissão ou progressão. Assim, no curso de um insulto agudo, quanto maior a sinalização pró-proliferação, mais propenso o tecido estará para se regenerar mais rapidamente. Em adição, Wegiel e colaboradores demonstraram que a exposição ao CO gera uma importante sinalização pró-proliferativa e que, de forma interessante, essa sinalização só é observada em células não cancerígenas. Nos tecidos tumorais, o tratamento com $\mathrm{CO}$ promove um impressionante efeito contrário [223].

Assim, podemos sugerir que os dados da literatura confirmam nossos resultados, indicando que o efeito protetor do tratamento com $\mathrm{CO}$ se estende também a uma alteração metabólica celular, com melhora da sua capacidade energética e um favorecimento a recuperação tecidual. 
Enfim, baseado em nossos resultados e tendo como referência outros estudos realizados, podemos inferir que a indução da expressão do sistema da HO-1 promove uma série de efeitos citoprotetores. E apesar de que a expressão dessa enzima pode refletir em um conjunto de mecanismos de ações pleiotrópicos ou multifatoriais, a identificação da real contribuição de cada um dos componentes desse sistema poderá fazer com que, num futuro próximo, a tradução desses na prática clínica seja um evento corriqueiro. 
6 CONCLUSÕES 
Tendo como base nossos resultados, podemos concluir que a indução da HO-1 é benéfica em modelos in vivo e in vitro de LRA, através da modulação negativa do ERS, por atenuar a inflamação, a hipóxia e o estresse oxidativo.

Especificamente, podemos concluir que:

- Animais tratados com Hemin exibiram uma melhora da função renal, com níveis séricos menores de creatinina e uréia;

- Após a lesão renal, há um aumento da expressão gênica de TNF- $\alpha$, BiP e CHOP, fato revertido pelo tratamento com Hemin;

- A indução de HO-1 nas células renais atenuou o processo de ERS, sendo mediado pela ativação da p38 MAPK;

- O tratamento com CO promove uma melhora da função renal, acompanhado de menos inflamação e uma preservação da histologia renal;

- A exposição ao CO leva a um aumento da sinalização purinérgica antiinflamatória;

- O tratamento com CO promove uma maior expressão de Per2, levando à estabilização de HIF-1 $\alpha$. Como consequência, há maior proteção de eritropoietina, a qual gera um importante efeito protetor nas células; e

- A exposição ao CO leva a um aumento da biogênese mitocondrial, gerando mais energia para a célula, colaborando para uma rápida recuperação após o insulto isquêmico. 
7 CONCLUSÃO ILUSTRATIVA 
Figura 42 - Esquema indicativo da proteção mediada pela HO-1/CO na lesão renal aguda.

A.

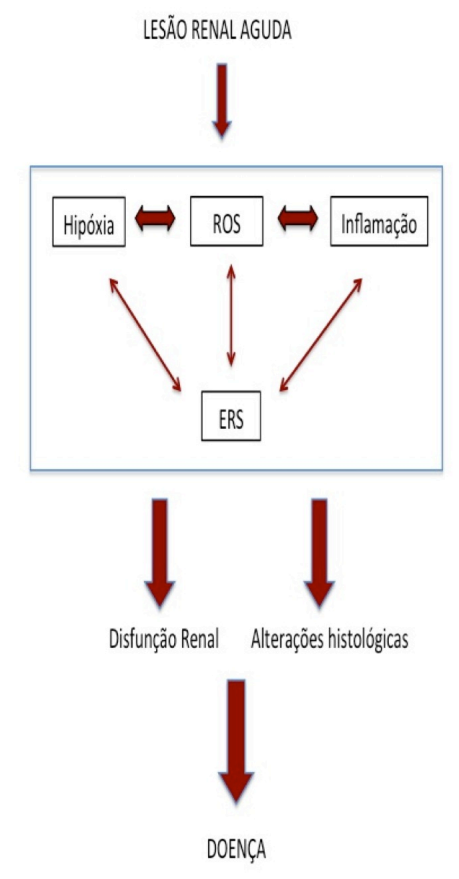

B.

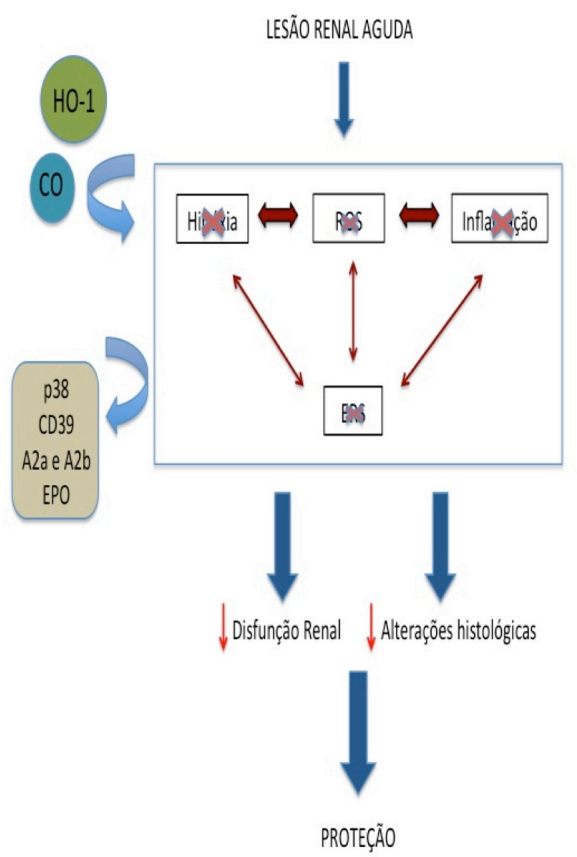

A) Após um episódio de LRA, como durante a lesão renal isquêmica, há um aumento da hipóxia, do estresse oxidativo e da inflamação. Essa tríade não só ativa o ERS, como também é alvo do mesmo, exacerbando assim o insulto celular. Como consequência, há perda de função do órgão, acompanhado de alteração histológica, prevalecendo assim a doença. B) Na presença de HO-1 e/ou CO há uma atenuação da hipóxia, estresse oxidativo e inflamação subsequente à LRA. Assim, ocorre uma regulação negativa da ativação de ERS. Tais alterações parecem ser mediadas pelo aumento de uma série de moléculas, como p38, CD39, receptores de adenosina do tipo II e EPO. Consequentemente, há uma redução da disfunção renal e preservação do aspecto histológico normal, com prevalecimento da proteção tecidual. 
REFERENNCIAS 


\section{REFERÊNCIAS ${ }^{1}$}

1. LI, P. K.; BURDMANN, E. A.; MEHTA, R. L. Acute kidney injury: global health alert. Transplantation, v. 95, n. 5, p. 653-657, 2013.

2. KELLUM, J. A.; LAMEIRE, N. Diagnosis, evaluation, and management of acute kidney injury: a KDIGO summary (Part 1). Crit. Care, v. 17, n. 1, p. 204, 2013.

3. VIEIRA, J. M.; CASTRO, I.; CURVELlO-NETO, A.; DEMARZO, S.; CARUSO, P.; PASTORE, L.; IMANISHE, M. H.; ABDULKADER, R. C.; DEHEINZELIN, D. Effect of acute kidney injury on weaning from mechanical ventilation in critically ill patients. Crit. Care Med., v. 35, n. 1, p. 184-191, 2007.

4. BOUCHARD, J.; SOROKO, S. B.; CHERTOW, G. M.; HIMMELFARB, J.; IKIZLER, T. A.; PAGANINI, E. P.; MEHTA, R. L. Fluid accumulation, survival and recovery of kidney function in critically ill patients with acute kidney injury. Kidney Int., v. 76, n. 4, p. 422-427, 2009.

5. FISCHER, M. J.; BRIMHALL, B. B.; PARIKH, C. R. Uncomplicated acute renal failure and post-hospital care: a not so uncomplicated illness. Am. J. Nephrol., v. 28, n. 3, p. 523$530,2008$.

6. THAKAR, C. V.; CHRISTIANSON, A.; HIMMELFARB, J.; LEONARD, A. C. Acute kidney injury episodes and chronic kidney disease risk in diabetes mellitus. Clin. J. Am. Soc. Nephrol., v. 6, n. 11, p. 2567-2572, 2011.

7. THADHANI, R.; PASCUAL, M.; BONVENTRE, J. V. Acute renal failure. N. Engl. J. Med., v. 334, n. 22, p. 1448-1460, 1996.

8. SCHRIER, R. W.; WANG, W.; POOLE, B.; MITRA, A. Acute renal failure: definitions, diagnosis, pathogenesis, and therapy. J. Clin. Invest., v. 114, n. 1, p. 5-14, 2004.

9. BONVENTRE, J. V.; ZUK, A. Ischemic acute renal failure: an inflammatory disease? Kidney Int., v. 66, n. 2, p. 480-485, 2004.

10. SOLEZ, K.; MOREL-MAROGER, L.; SRAER, J. D. The morphology of "acute tubular necrosis" in man: analysis of 57 renal biopsies and a comparison with the glycerol model. Medicine (Baltimore), v. 58, n. 5, p. 362-376, 1979.

11. THURMAN, J. M. Triggers of inflammation after renal ischemia/reperfusion. Clin. Immunol., v. 123, n. 1, p. 7-13, 2007.

12. BONVENTRE, J. V.; WEINBERG, J. M. Recent advances in the pathophysiology of ischemic acute renal failure. J. Am. Soc. Nephrol., v. 14, n. 8, p. 2199-2210, 2003.

\footnotetext{
${ }^{1}$ De acordo com:

ASSOCIAÇÃO BRASILEIRA DE NORMAS TÉCNICAS. NBR 6023: informação e documentação: referências: elaboração. Rio de Janeiro, 2002.
} 
13. YSEBAERT, D. K.; DE GREEF, K. E.; VERCAUTEREN, S. R.; GHIELLI, M.; VERPOOTEN, G. A.; EYSKENS, E. J.; DE BROE, M. E. Identification and kinetics of leukocytes after severe ischaemia/reperfusion renal injury. Nephrol. Dial. Transplant., v. 15, n. 10, p. 1562-1574, 2000.

14. FENG, Y.; CHAO, W. Toll-like receptors and myocardial inflammation. Int. J. Inflam., v. 2011, n. p. 170352, 2011.

15. MARCHANT, D. J.; BOYD, J. H.; LIN, D. C.; GRANVILLE, D. J.; GARMAROUDI, F. S.; MCMANUS, B. M. Inflammation in myocardial diseases. Circ. Res., v. 110, n. 1, p. 126$144,2012$.

16. VINCENT, A.; LATTUCA, B.; MERLET, N.; SPORTOUCH-DUKHAN, C.; BARRERE-LEMAIRE, S. New insights in research about acute ischemic myocardial injury and inflammation. Antiinflamm. Antiallergy Agents Med. Chem., v. 12, n. 1, p. 47-54, 2013 .

17. KAPADIA, S.; LEE, J.; TORRE-AMIONE, G.; BIRDSALL, H. H.; MA, T. S.; MANN, D. L. Tumor necrosis factor-alpha gene and protein expression in adult feline myocardium after endotoxin administration. J. Clin. Invest., v. 96, n. 2, p. 1042-1052, 1995.

18. MANN, D. L. Inflammatory mediators and the failing heart: past, present, and the foreseeable future. Circ. Res., v. 91, n. 11, p. 988-998, 2002.

19. KITAMURA, M. Endoplasmic reticulum stress in the kidney. Clin. Exp. Nephrol., v. 12, n. 5, p. 317-325, 2008.

20. KAUFMAN, R. J. Stress signaling from the lumen of the endoplasmic reticulum: coordination of gene transcriptional and translational controls. Genes Dev., v. 13, n. 10, p. 1211-1233, 1999.

21. MALHOTRA, J. D.; KAUFMAN, R. J. Endoplasmic reticulum stress and oxidative stress: a vicious cycle or a double-edged sword? Antioxid. Redox Signal., v. 9, n. 12, p. 2277-2293, 2007.

22. YOSHIDA, H. ER stress and diseases. Febs J., v. 274, n. 3, p. 630-658, 2007.

23. INAGI, R. Endoplasmic reticulum stress in the kidney as a novel mediator of kidney injury. Nephron Exp. Nephrol., v. 112, n. 1, p. e1-9, 2009.

24. NI, M.; LEE, A. S. ER chaperones in mammalian development and human diseases. FEBS Lett., v. 581, n. 19, p. 3641-3651, 2007.

25. VEMBAR, S S.; BRODSKY, J. L. One step at a time: endoplasmic reticulum-associated degradation. Nat. Rev. Mol. Cell Biol., v. 9, n. 12, p. 944-957, 2008.

26. YAMAMOTO, K.; SATO, T.; MATSUI, T.; SATO, M.; OKADA, T.; YOSHIDA, H.; HARADA, A.; MORI, K. Transcriptional induction of mammalian ER quality control 
proteins is mediated by single or combined action of ATF6alpha and XBP1. Dev. Cell, v. 13, n. 3, p. 365-376, 2007.

27. ZHANG, D. D. Mechanistic studies of the Nrf2-Keap1 signaling pathway. Drug Metab. Rev., v. 38, n. 4, p. 769-789, 2006.

28. ADACHI, Y.; YAMAMOTO, K.; OKADA, T.; YOSHIDA, H.; HARADA, A.; MORI, K. ATF6 is a transcription factor specializing in the regulation of quality control proteins in the endoplasmic reticulum. Cell Struct. Funct., v. 33, n. 1, p. 75-89, 2008.

29. RON, D.; WALTER, P. Signal integration in the endoplasmic reticulum unfolded protein response. Nat. Rev. Mol. Cell Biol., v. 8, n. 7, p. 519-529, 2007.

30. OGAWA, S.; KITAO, Y.; HORI, O. Ischemia-induced neuronal cell death and stress response. Antioxid. Redox Signal., v. 9, n. 5, p. 573-587, 2007.

31. OYADOMARI, S.; MORI, M. Roles of CHOP/GADD153 in endoplasmic reticulum stress. Cell Death Differ, v. 11, n. 4, p. 381-389, 2004.

32. XU, C.; BAILLY-MAITRE, B.; REED, J. C. Endoplasmic reticulum stress: cell life and death decisions. J. Clin. Invest., v. 115, n. 10, p. 2656-2664, 2005.

33. ZHANG, K.; KAUFMAN, R. J. The unfolded protein response: a stress signaling pathway critical for health and disease. Neurology, v. 66, n. 2 Suppl 1, p. S102-109, 2006.

34. TESSARI, P.; GARIBOTTO, G.; INCHIOSTRO, S.; ROBAUDO, C.; SAFFIOTI, S.; VETTORE, M.; ZANETTI, M.; RUSSO, R.; DEFERRARI, G. Kidney, splanchnic, and leg protein turnover in humans. Insight from leucine and phenylalanine kinetics. J. Clin. Invest., v. 98, n. 6, p. 1481-1492, 1996.

35. KREPINSKY, J.; DICKHOUT, J. G. Endoplasmic Reticulum Stress and Renal Disease. Antioxid. Redox Signal., v. n. p. 2009.

36. RICKETTS, W. G.; BIRCHENALL-SPARKS, M. C.; HARDWICK, J. P.; RICHARDSON, A. Effect of age and dietary restriction on protein synthesis by isolated kidney cells. J. Cell Physiol., v. 125, n. 3, p. 492-498, 1985.

37. KIMURA, K.; JIN, H.; OGAWA, M.; AOE, T. Dysfunction of the ER chaperone BiP accelerates the renal tubular injury. Biochem. Biophys. Res. Commun., v. 366, n. 4, p. 1048$1053,2008$.

38. MIMURA, N.; HAMADA, H.; KASHIO, M.; JIN, H.; TOYAMA, Y.; KIMURA, K.; IIDA, M.; GOTO, S.; SAISHO, H.; TOSHIMORI, K.; KOSEKI, H.; AOE, T. Aberrant quality control in the endoplasmic reticulum impairs the biosynthesis of pulmonary surfactant in mice expressing mutant BiP. Cell Death. Differ., v. 14, n. 8, p. 1475-1485, 2007.

39. CYBULSKY, A. V.; TAKANO, T.; PAPILlON, J.; KHADIR, A.; LIU, J.; PENG, H. Complement C5b-9 membrane attack complex increases expression of endoplasmic reticulum stress proteins in glomerular epithelial cells. J. Biol. Chem., v. 277, n. 44, p. 41342-41351, 2002. 
40. INAGI, R.; KUMAGAI, T.; NISHI, H.; KAWAKAMI, T.; MIYATA, T.; FUJITA, T.; NANGAKU, M. Preconditioning with endoplasmic reticulum stress ameliorates mesangioproliferative glomerulonephritis. J. Am. Soc. Nephrol., v. 19, n. 5, p. 915-922, 2008.

41. SIKORSKI, E. M.; HOCK, T.; HILL-KAPTURCZAK, N.; AGARWAL, A. The story so far: Molecular regulation of the heme oxygenase-1 gene in renal injury. Am. J. Physiol. Renal Physiol., v. 286, n. 3, p. F425-441, 2004.

42. ABRAHAM, N. G.; FRIEDLAND, M. L.; LEVERE, R. D. Heme metabolism in erythroid and hepatic cells. Prog. Hematol., v. 13, n. p. 75-130, 1983.

43. HILL-KAPTURCZAK, N.; CHANG, S. H.; AGARWAL, A. Heme oxygenase and the kidney. DNA Cell Biol., v. 21, n. 4, p. 307-321, 2002.

44. TENHUNEN, R.; MARVER, H. S.; SCHMID, R. The enzymatic conversion of heme to bilirubin by microsomal heme oxygenase. Proc. Natl. Acad. Sci. U S A, v. 61, n. 2, p. 748$755,1968$.

45. ABRAHAM, N. G.; CAO, J.; SACERDOTI, D.; LI, X.; DRUMMOND, G. Heme oxygenase: the key to renal function regulation. Am. J. Physiol. Renal Physiol., v. 297, n. 5, p. F1137-1152, 2009.

46. COURTNEY, A. E.; MAXWELL, A. P. Heme oxygenase 1: does it have a role in renal cytoprotection? Am. J. Kidney Dis., v. 51, n. 4, p. 678-690, 2008.

47. CAO, Y. A.; KUSY, S.; LUONG, R.; WONG, R. J.; STEVENSON, D. K.; CONTAG, C. H. Heme oxygenase-1 deletion affects stress erythropoiesis. PLoS One, v. 6, n. 5, p. e20634, 2011.

48. KOVTUNOVYCH, G.; ECKHAUS, M. A.; GHOSH, M. C.; OLLIVIERRE-WILSON, H.; ROUAULT, T. A. Dysfunction of the heme recycling system in heme oxygenase 1deficient mice: effects on macrophage viability and tissue iron distribution. Blood, v. 116, n. 26, p. 6054-6062, 2010.

49. AGARWAL, A.; NICK, H. S. Renal response to tissue injury: lessons from heme oxygenase-1 GeneAblation and expression. J. Am. Soc. Nephrol., v. 11, n. 5, p. 965-973, 2000 .

50. HAYASHI, S.; OMATA, Y.; SAKAMOTO, H.; HIGASHIMOTO, Y.; HARA, T.; SAGARA, Y.; NOGUCHI, M. Characterization of rat heme oxygenase-3 gene. Implication of processed pseudogenes derived from heme oxygenase-2 gene. Gene, v. 336, n. 2, p. 241-250, 2004.

51. RYTER, S. W.; TYRRELL, R. M. The heme synthesis and degradation pathways: role in oxidant sensitivity. Heme oxygenase has both pro- and antioxidant properties. Free Radic. Biol. Med., v. 28, n. 2, p. 289-309, 2000. 
52. JUCKETT, M. B.; BALLA, J.; BALLA, G.; JESSURUN, J.; JACOB, H. S.; VERCELLOTTI, G. M. Ferritin protects endothelial cells from oxidized low density lipoprotein in vitro. Am. J. Pathol., v. 147, n. 3, p. 782-789, 1995.

53. STOCKER, R. Antioxidant activities of bile pigments. Antioxid. Redox Signal., v. 6, n. 5, p. 841-849, 2004.

54. XIA, Z. W.; ZHONG, W. W.; MEYROWITZ, J. S.; ZHANG, Z. L. The role of heme oxygenase- 1 in T cell-mediated immunity: the all encompassing enzyme. Curr. Pharm. Des., v. 14, n. 5, p. 454-464, 2008.

55. BURT, T. D.; SEU, L.; MOLD, J. E.; KAPPAS, A.; MCCUNE, J. M. Naive human T cells are activated and proliferate in response to the heme oxygenase-1 inhibitor tin mesoporphyrin. J. Immunol., v. 185, n. 9, p. 5279-5288, 2010.

56. CHOI, B. M.; PAE, H. O.; JEONG, Y. R.; KIM, Y. M.; CHUNG, H. T. Critical role of heme oxygenase-1 in Foxp3-mediated immune suppression. Biochem. Biophys. Res. Commun., v. 327, n. 4, p. 1066-1071, 2005.

57. PAE, H. O.; OH, G. S.; CHOI, B. M.; CHAE, S. C.; CHUNG, H. T. Differential expressions of heme oxygenase-1 gene in CD25- and CD25+ subsets of human CD4+ T cells. Biochem. Biophys. Res. Commun., v. 306, n. 3, p. 701-705, 2003.

58. ZHONG, W.; XIA, Z.; HINRICHS, D.; ROSENBAUM, J. T.; WEGMANN, K. W.; MEYROWITZ, J.; ZHANG, Z. Hemin exerts multiple protective mechanisms and attenuates dextran sulfate sodium-induced colitis. J. Pediatr. Gastroenterol. Nutr., v. 50, n. 2, p. 132$139,2010$.

59. CHENG, C.; NOORDERLOOS, M.; VAN DEEL, E. D.; TEMPEL, D.; DEN DEKKER, W.; WAGTMANS, K.; DUNCKER, D. J.; SOARES, M. P.; LAMAN, J. D.; DUCKERS, H. $\mathrm{J}$. Dendritic cell function in transplantation arteriosclerosis is regulated by heme oxygenase 1 . Circ. Res., v. 106, n. 10, p. 1656-1666, 2010.

60. WAGENER, F. A.; ABRAHAM, N. G.; VAN KOOYK, Y.; DE WITTE, T.; FIGDOR, C. G. Heme-induced cell adhesion in the pathogenesis of sickle-cell disease and inflammation. Trends Pharmacol. Sci., v. 22, n. 2, p. 52-54, 2001.

61. WHITE, K. A.; MARLETTA, M. A. Nitric oxide synthase is a cytochrome P-450 type hemoprotein. Biochemistry, v. 31, n. 29, p. 6627-6631, 1992.

62. GOZZELINO, R.; JENEY, V.; SOARES, M. P. Mechanisms of cell protection by heme oxygenase-1. Annu. Rev. Pharmacol. Toxicol., v. 50, n. p. 323-354, 2010.

63. CORREA-COSTA, M.; SEMEDO, P.; MONTEIRO, A. P.; SILVA, R. C.; PEREIRA, R. L.; GONCALVES, G. M.; MARQUES, G. D.; CENEDEZE, M. A.; FALEIROS, A. C.; KELLER, A. C.; SHIMIZU, M. H.; SEGURO, A. C.; REIS, M. A.; PACHECO-SILVA, A.; CAMARA, N. O. Induction of heme oxygenase- 1 can halt and even reverse renal tubuleinterstitial fibrosis. PLoS One, v. 5, n. 12, p. e14298, 2010. 
64. LEE, H. T.; XU, H.; OTA-SETLIK, A.; EMALA, C. W. Oxidant preconditioning protects human proximal tubular cells against lethal oxidant injury via p38 MAPK and heme oxygenase-1. Am. J. Nephrol., v. 23, n. 5, p. 324-333, 2003.

65. POSS, K. D.; TONEGAWA, S. Heme oxygenase 1 is required for mammalian iron reutilization. Proc. Natl. Acad. Sci. U S A, v. 94, n. 20, p. 10919-10924, 1997.

66. KAPTURCZAK, M. H.; WASSERFALL, C.; BRUSKO, T.; CAMPBELL-THOMPSON, M.; ELLIS, T. M.; ATKINSON, M. A.; AGARWAL, A. Heme oxygenase-1 modulates early inflammatory responses: evidence from the heme oxygenase-1-deficient mouse. Am. J. Pathol., v. 165, n. 3, p. 1045-1053, 2004.

67. MORSE, D.; LIN, L.; CHOI, A. M.; RYTER, S. W. Heme oxygenase-1, a critical arbitrator of cell death pathways in lung injury and disease. Free Radic. Biol. Med., v. 47, n. 1, p. 1-12, 2009.

68. PIMSTONE, N. R.; ENGEL, P.; TENHUNEN, R.; SEITZ, P.T.; MARVER, H.S.; SCHMID, R. Inducible heme oxygenase in the kidney: a model for the homeostatic control of hemoglobin catabolism. J. Clin. Invest., v. 50, n. 10, p. 2042-2050, 1971.

69. DA SILVA, J. L.; ZAND, B. A.; YANG, L. M.; SABAAWY, H. E.; LIANOS, E.; ABRAHAM, N. G. Heme oxygenase isoform-specific expression and distribution in the rat kidney. Kidney Int., v. 59, n. 4, p. 1448-1457, 2001.

70. SHIMIZU, H.; TAKAHASHI, T.; SUZUKI, T.; YAMASAKI, A.; FUJIWARA, T.; ODAKA, Y.; HIRAKAWA, M.; FUJITA, H.; AKAGI, R. Protective effect of heme oxygenase induction in ischemic acute renal failure. Crit. Care Med., v. 28, n. 3, p. 809-817, 2000 .

71. AKAGI, R.; TAKAHASHI, T.; SASSA, S. Cytoprotective effects of heme oxygenase in acute renal failure. Contrib. Nephrol., v. 148, n. p. 70-85, 2005.

72. HOLZEN, J. P.; AUGUST, C.; BAHDE, R.; MININ, E.; LANG, D.; HEIDENREICH, S.; DIETL, K. H.; SPIEGEL, H. U. Influence of heme oxygenase-1 on microcirculation after kidney transplantation. J. Surg. Res., v. 148, n. 2, p. 126-135, 2008.

73. MATSUMOTO, M.; MAKINO, Y.; TANAKA, T.; TANAKA, H.; ISHIZAKA, N.; NOIRI, E.; FUJITA, T.; NANGAKU, M. Induction of renoprotective gene expression by cobalt ameliorates ischemic injury of the kidney in rats. J. Am. Soc. Nephrol., v. 14, n. 7, p. $1825-1832,2003$.

74. WU, Q. Q.; WANG, Y.; SENITKO, M.; MEYER, C.; WIGLEY, W.C.; FERGUSON, D. A.; GROSSMAN, E.; CHEN, J.; ZHOU, X. J.; HARTONO, J.; WINTERBERG, P.; CHEN, B.; AGARWAL, A.; LU, C. Y. Bardoxolone methyl (BARD) ameliorates ischemic AKI and increases expression of protective genes Nrf2, PPARgamma, and HO-1. Am. J. Physiol. Renal Physiol., v. 300, n. 5, p. F1180-1192, 2011.

75. NATH, K. A.; BALlA, G.; VERCELlOTTI, G. M.; BALlA, J.; JACOB, H. S.; LEVITT, M. D.; ROSENBERG, M. E. Induction of heme oxygenase is a rapid, protective response in rhabdomyolysis in the rat. J. Clin. Invest., v. 90, n. 1, p. 267-270, 1992. 
76. NATH, K. A.; HAGGARD, J. J.; CROATT, A. J.; GRANDE, J. P.; POSS, K. D.; ALAM, $\mathrm{J}$. The indispensability of heme oxygenase- 1 in protecting against acute heme protein-induced toxicity in vivo. Am. J. Pathol., v. 156, n. 5, p. 1527-1535, 2000.

77. MOTTERLINI, R.; OTTERBEIN, L. E. The therapeutic potential of carbon monoxide. Nat. Rev. Drug Discov., v. 9, n. 9, p. 728-743, 2010.

78. GOLDBAUM, L. R.; ORELLANO, T.; DERGAL, E. Mechanism of the toxic action of carbon monoxide. Ann. Clin. Lab. Sci., v. 6, n. 4, p. 372-376, 1976.

79. BOEHNING, D; SNYDER, S. H. Circadian rhythms. Carbon monoxide and clocks. Science, v. 298, n. 5602, p. 2339-2340, 2002.

80. KOBAYASHI, A.; ISHIKAWA, K.; MATSUMOTO, H.; KIMURA, S.; KAMIYAMA, Y.; MARUYAMA, Y. Synergetic antioxidant and vasodilatory action of carbon monoxide in angiotensin II - induced cardiac hypertrophy. Hypertension, v. 50, n. 6, p. 1040-1048, 2007.

81. ZHUO, M.; SMALL, S. A.; KANDEL, E. R.; HAWKINS, R. D. Nitric oxide and carbon monoxide produce activity-dependent long-term synaptic enhancement in hippocampus. Science, v. 260, n. 5116, p. 1946-1950, 1993.

82. BOCZKOWSKI, J.; PODEROSO, J. J.; MOTTERLINI, R. CO-metal interaction: Vital signaling from a lethal gas. Trends Biochem. Sci., v. 31, n. 11, p. 614-621, 2006.

83. WEGIEL, B.; HANTO, D. W.; OTTERBEIN, L. E. The social network of carbon monoxide in medicine. Trends Mol. Med., v. 19, n. 1, p. 3-11, 2013.

84. FORESTI, R.; HAMMAD, J.; CLARK, J. E.; JOHNSON, T. R.; MANN, B. E.; FRIEBE, A.; GREEN, C. J.; MOTTERLINI, R. Vasoactive properties of CORM-3, a novel watersoluble carbon monoxide-releasing molecule. Br. J. Pharmacol., v. 142, n. 3, p. 453-460, 2004.

85. VANDEGRIFF, K. D.; YOUNG, M. A.; LOHMAN, J.; BELLELLI, A.; SAMAJA, M.; MALAVALLI, A.; WINSLOW, R. M. CO-MP4, a polyethylene glycol-conjugated haemoglobin derivative and carbon monoxide carrier that reduces myocardial infarct size in rats. Br. J. Pharmacol., v. 154, n. 8, p. 1649-1661, 2008.

86. WANG, X. M.; KIM, H. P.; NAKAHIRA, K.; RYTER, S. W.; CHOI, A. M. The heme oxygenase-1/carbon monoxide pathway suppresses TLR4 signaling by regulating the interaction of TLR4 with caveolin-1. J. Immunol., v. 182, n. 6, p. 3809-3818, 2009.

87. WOO, C. H.; MASSETT, M. P.; SHISHIDO, T.; ITOH, S.; DING, B.; MCCLAIN, C.; CHE, W.; VULAPALLI, S. R.; YAN, C.; ABE, J. ERK5 activation inhibits inflammatory responses via peroxisome proliferator-activated receptor delta (PPARdelta) stimulation. J. Biol. Chem., v. 281, n. 43, p. 32164-32174, 2006.

88. BILBAN, M.; BACH, F. H.; OTTERBEIN, S. L.; IFEDIGBO, E.; D'AVILA, J. C.; ESTERBAUER, H.; CHIN, B. Y.; USHEVA, A.; ROBSON, S. C.; WAGNER, O.; 
OTTERBEIN, L. E. Carbon monoxide orchestrates a protective response through PPARgamma. Immunity, v. 24, n. 5, p. 601-610, 2006.

89. BILBAN, M.; HASCHEMI, A.; WEGIEL, B.; CHIN, B. Y.; WAGNER, O.; OTTERBEIN, L. E. Heme oxygenase and carbon monoxide initiate homeostatic signaling. J. Mol. Med. (Berl), v. 86, n. 3, p. 267-279, 2008.

90. ROCHETTE, L.; COTTIN, Y.; ZELLER, M.; VERGELY, C. Carbon monoxide: mechanisms of action and potential clinical implications. Pharmacol. Ther., v. 137, n. 2, p. 133-152, 2013.

91. LEE, S. J.; RYTER, S. W.; XU, J. F.; NAKAHIRA, K.; KIM, H. P.; CHOI, A. M.; KIM, Y. S. Carbon monoxide activates autophagy via mitochondrial reactive oxygen species formation. Am. J. Respir. Cell Mol. Biol., v. 45, n. 4, p. 867-873, 2011.

92. PAMPLONA, A.; FERREIRA, A.; BALLA, J.; JENEY, V.; BALLA, G.; EPIPHANIO, S.; CHORA, A.; RODRIGUES, C. D.; GREGOIRE, I. P.; CUNHA-RODRIGUES, M.; PORTUGAL, S; SOARES, M. P.; MOTA, M. M. Heme oxygenase-1 and carbon monoxide suppress the pathogenesis of experimental cerebral malaria. Nat. Med., v. 13, n. 6, p. $703-$ $710,2007$.

93. CEPINSKAS, G.; KATADA, K.; BIHARI, A.; POTTER, R. F. Carbon monoxide liberated from carbon monoxide-releasing molecule CORM-2 attenuates inflammation in the liver of septic mice. Am. J. Physiol. Gastrointest. Liver Physiol., v. 294, n. 1, p. G184-191, 2008.

94. AMEREDES, B, T.; OTTERBEIN, L. E.; KOHUT, L. K.; GLIGONIC, A. L.; CALHOUN, W.J ; CHOI, A. M. Low-dose carbon monoxide reduces airway hyperresponsiveness in mice. Am. J. Physiol. Lung Cell Mol. Physiol., v. 285, n. 6, p. L1270-1276, 2003.

95. FERRANDIZ, M.L.; MAICAS, N.; GARCIA-ARNANDIS, I.; TERENCIO, M.C.; MOTTERLINI, R.; DEVESA, I.; JOOSTEN, L.A.; VAN DEN BERG, W.B.; ALCARAZ, M.J. Treatment with a CO-releasing molecule (CORM-3) reduces joint inflammation and erosion in murine collagen-induced arthritis. Ann. Rheum. Dis., v. 67, n. 9, p. 1211-1217, 2008.

96. HEGAZI, R. A.; RAO, K. N.; MAYLE, A.; SEPULVEDA, A. R.; OTTERBEIN, L. E.; PLEVY, S. E. Carbon monoxide ameliorates chronic murine colitis through a heme oxygenase 1-dependent pathway. J. Exp. Med., v. 202, n. 12, p. 1703-1713, 2005.

97. BOURS, M. J.; SWENNEN, E. L.; DI VIRGILIO, F.; CRONSTEIN, B. N.; DAGNELIE, P. C. Adenosine 5'-triphosphate and adenosine as endogenous signaling molecules in immunity and inflammation. Pharmacol. Ther., v. 112, n. 2, p. 358-404, 2006.

98. NOVAK, I. ATP as a signaling molecule: the exocrine focus. News Physiol. Sci., v. 18, n. p. 12-17, 2003.

99. RESTA, R.; YAMASHITA, Y.; THOMPSON, L. F. Ecto-enzyme and signaling functions of lymphocyte CD73. Immunol. Rev., v. 161, n. p. 95-109, 1998. 
100. REGATEIRO, F. S.; COBBOLD, S. P.; WALDMANN, H. CD73 and adenosine generation in the creation of regulatory microenvironments. Clin. Exp. Immunol., v. 171, n. 1, p. 1-7, 2012.

101. ELTZSCHIG, H. K.; SITKOVSKY, M. V.; ROBSON, S. C. Purinergic signaling during inflammation. N. Engl. J. Med., v. 367, n. 24, p. 2322-2333, 2012.

102. YAP, S.C.; LEE, H.T. Adenosine and protection from acute kidney injury. Curr. Opin. Nephrol. Hypertens., v. 21, n. 1, p. 24-32, 2012.

103. GRENZ, A.; ZHANG, H.; HERMES, M.; ECKLE, T.; KLINGEL, K.; HUANG, D. Y.; MULLER, C. E.; ROBSON, S. C.; OSSWALD, H.; ELTZSCHIG, H. K.. Contribution of ENTPDase1 (CD39) to renal protection from ischemia-reperfusion injury. Faseb J., v. 21, n. 11, p. 2863-2873, 2007.

104. CRIKIS, S.; LU, B.; MURRAY-SEGAL, L.M.; SELAN, C.; ROBSON, S.C.; D'APICE, A. J.; NANDURKAR, H. H.; COWAN, P. J.; DWYER, K. M. Transgenic overexpression of CD39 protects against renal ischemia-reperfusion and transplant vascular injury. Am. J. Transplant., v. 10, n. 12, p. 2586-2595, 2010.

105. LEE, H. T.; EMALA, C. W. Adenosine attenuates oxidant injury in human proximal tubular cells via A(1) and A(2a) adenosine receptors. Am. J. Physio.l Renal Physiol., v. 282, n. 5, p. F844-852, 2002.

106. OKUSA, M. D. A(2A) adenosine receptor: a novel therapeutic target in renal disease. Am. J. Physiol. Renal Physiol., v. 282, n. 1, p. F10-18, 2002.

107. SCHOLZ-PEDRETTI, K.; PFEILSCHIFTER, J.; KASZKIN, M. Potentiation of cytokine induction of group IIA phospholipase A(2) in rat mesangial cells by ATP and adenosine via the A2A adenosine receptor. Br. J. Pharmacol., v. 132, n. 1, p. 37-46, 2001.

108. DAY, Y. J.; HUANG, L.; MCDUFFIE, M. J.; ROSIN, D. L.; YE, H.; CHEN, J. F.; SCHWARZSCHILD, M. A.; FINK, J. S.; LINDEN, J.; OKUSA, M. D. Renal protection from ischemia mediated by $\mathrm{A} 2 \mathrm{~A}$ adenosine receptors on bone marrow-derived cells. J. Clin. Invest., v. 112, n. 6, p. 883-891, 2003.

109. OKUSA, M.D.; LINDEN, J.; HUANG, L.; RIEGER, J.M.; MACDONALD, T.L.; HUYNH, L.P. A(2A) adenosine receptor-mediated inhibition of renal injury and neutrophil adhesion. Am. J. Physiol. Renal Physiol., v. 279, n. 5, p. F809-818, 2000.

110. OKUSA, M. D.; LINDEN, J.; HUANG, L.; ROSIN, D. L.; SMITH, D. F.; SULLIVAN, G. Enhanced protection from renal ischemia-reperfusion [correction of ischemia:reperfusion] injury with A(2A)-adenosine receptor activation and PDE 4 inhibition. Kidney Int., v. 59, n. 6, p. 2114-2125, 2001.

111. OKUSA, M. D.; LINDEN, J.; MACDONALD, T.; HUANG, L. Selective A2A adenosine receptor activation reduces ischemia-reperfusion injury in rat kidney. Am. J. Physiol., v. 277, n. 3 Pt 2, p. F404-412, 1999.

112. MAXWELL, P. H. Hypoxia-inducible factor as a physiological regulator. Exp. Physiol., v. 90, n. 6, p. 791-797, 2005. 
113. SEMENZA, G. L. Surviving ischemia: adaptive responses mediated by hypoxiainducible factor 1. J. Clin. Invest., v. 106, n. 7, p. 809-812, 2000.

114. WANG, G. L.; JIANG, B. H.; RUE, E. A.; SEMENZA, G. L. Hypoxia-inducible factor 1 is a basic-helix-loop-helix-PAS heterodimer regulated by cellular O2 tension. Proc. Natl. Acad. Sci. U S A, v. 92, n. 12, p. 5510-5514, 1995.

115. SEMENZA, G. L. Targeting HIF-1 for cancer therapy. Nat. Rev. Cancer, v. 3, n. 10, p. 721-732, 2003.

116. FIRTH, J. D.; EBERT, B. L.; PUGH, C. W.; RATCLIFFE, P. J. Oxygen-regulated control elements in the phosphoglycerate kinase 1 and lactate dehydrogenase A genes: similarities with the erythropoietin 3' enhancer. Proc. Natl. Acad. Sci. U S A, v. 91, n. 14, p. 6496-6500, 1994.

117. LEE, P. J.; JIANG, B H.; CHIN, B. Y.; IYER, N. V.; ALAM, J.; SEMENZA, G. L.; CHOI, A.M. Hypoxia-inducible factor-1 mediates transcriptional activation of the heme oxygenase-1 gene in response to hypoxia. J. Biol. Chem., v. 272, n. 9, p. 5375-5381, 1997.

118. LEVY, A. P.; LEVY, N. S.; WEGNER, S.; GOLDBERG, M. A. Transcriptional regulation of the rat vascular endothelial growth factor gene by hypoxia. J. Biol. Chem., v. 270, n. 22, p. 13333-13340, 1995.

119. MELILLO, G.; MUSSO, T.; SICA, A.; TAYLOR, L. S.; COX, G. W.; VARESIO, L. A hypoxia-responsive element mediates a novel pathway of activation of the inducible nitric oxide synthase promoter. J. Exp. Med., v. 182, n. 6, p. 1683-1693, 1995.

120. SEMENZA, G. L.; WANG, G. L. A nuclear factor induced by hypoxia via de novo protein synthesis binds to the human erythropoietin gene enhancer at a site required for transcriptional activation. Mol. Cell Biol., v. 12, n. 12, p. 5447-5454, 1992.

121. BOnVEntre, J. V. Kidney ischemic preconditioning. Curr. Opin. Nephrol. Hypertens., v. 11, n. 1, p. 43-48, 2002.

122. GIDDAY, J. M. Cerebral preconditioning and ischaemic tolerance. Nat. Rev. Neurosci., v. 7, n. 6, p. 437-448, 2006.

123. YELLON, D. M.; HAUSENLOY, D. J. Realizing the clinical potential of ischemic preconditioning and postconditioning. Nat. Clin. Pract. Cardiovasc. Med., v. 2, n. 11, p. 568-575, 2005.

124. BURGER, D. E.; XIANG, F. L.; HAMMOUD, L.; JONES, D. L.; FENG, Q. Erythropoietin protects the heart from ventricular arrhythmia during ischemia and reperfusion via neuronal nitric-oxide synthase. J. Pharmacol. Exp. Ther., v. 329, n. 3, p. 900-907, 2009.

125. GUNNARSON, E.; SONG, Y.; KOWALEWSKI, J. M.; BRISMAR, H.; BRINES, M.; CERAMI, A.; ANDERSSON, U.; ZELENINA, M.; APERIA, A. Erythropoietin modulation of astrocyte water permeability as a component of neuroprotection. Proc. Natl. Acad. Sci. U S A, v. 106, n. 5, p. 1602-1607, 2009. 
126. HOCHHAUSER, E.; PAPPO, O.; RIBAKOVSKY, E.; RAVID, A.; KURTZWALD, E.; CHEPORKO, Y.; LELCHUK, S.; BEN-ARI, Z. Recombinant human erythropoietin attenuates hepatic injury induced by ischemia/reperfusion in an isolated mouse liver model. Apoptosis, v. 13, n. 1, p. 77-86, 2008.

127. SPANDOU, E.; TSOUCHNIKAS, I.; KARKAVELAS, G.; DOUNOUSI, E.; SIMEONIDOU, C.; GUIBA-TZIAMPIRI, O.; TSAKIRIS, D. Erythropoietin attenuates renal injury in experimental acute renal failure ischaemic/reperfusion model. Nephrol. Dial. Transplant., v. 21, n. 2, p. 330-336, 2006.

128. CHANDEL, N. S.; MALTEPE, E.; GOLDWASSER, E.; MATHIEU, C. E.; SIMON, M. C.; SCHUMACKER, P. T. Mitochondrial reactive oxygen species trigger hypoxiainduced transcription. Proc. Natl. Acad. Sci. U S A, v. 95, n. 20, p. 11715-11720, 1998.

129. JUNK, A. K.; MAMMIS, A.; SAVITZ, S. I.; SINGH, M.; ROTH, S.; MALHOTRA, S.; ROSENBAUM, P. S.; CERAMI, A.; BRINES, M.; ROSENBAUM, D. M. Erythropoietin administration protects retinal neurons from acute ischemia-reperfusion injury. Proc. Natl. Acad. Sci. U S A, v. 99, n. 16, p. 10659-10664, 2002.

130. KIM, C. H.; CHO, Y. S.; CHUN, Y. S.; PARK, J. W.; KIM, M. S. Early expression of myocardial HIF-1alpha in response to mechanical stresses: regulation by stretch-activated channels and the phosphatidylinositol 3-kinase signaling pathway. Circ. Res., v. 90, n. 2, p. E25-33, 2002.

131. SHYU, K. G.; WANG, M. T.; WANG, B. W.; CHANG, C. C.; LEU, J. G.; KUAN, P.; CHANG, H. Intramyocardial injection of naked DNA encoding HIF-1alpha/VP16 hybrid to enhance angiogenesis in an acute myocardial infarction model in the rat. Cardiovasc. Res., v. 54, n. 3, p. 576-583, 2002.

132. KRUGEL, K.; WURM, A.; LINNERTZ, R.; PANNICKE, T.; WIEDEMANN, P.; REICHENBACH, A.; BRINGMANN, A. Erythropoietin inhibits osmotic swelling of retinal glial cells by Janus kinase- and extracellular signal-regulated kinases 1/2-mediated release of vascular endothelial growth factor. Neuroscience, v. 165, n. 4, p. 1147-1158, 2009.

133. MARZO, F.; LAVORGNA, A.; COLUZZI, G.; SANTUCCI, E.; TARANTINO, F.; RIO, T.; CONTI, E.; AUTORE, C.; AGATI, L.; ANDREOTTI, F. Erythropoietin in heart and vessels: focus on transcription and signalling pathways. J. Thromb. Thrombolysis, v. 26, n. 3, p. 183-187, 2008.

134. SHI, Z.; HODGES, V.M.; DUNLOP, E.A.; PERCY, M.J.; MAXWELL, A.P.; ELTANANI, M.; LAPPIN, T.R. Erythropoietin-induced activation of the JAK2/STAT5, PI3K/Akt, and Ras/ERK pathways promotes malignant cell behavior in a modified breast cancer cell line. Mol. Cancer Res., v. 8, n. 4, p. 615-626, 2010.

135. KATAVETIN, P.; INAGI, R.; MIYATA, T.; SHAO, J.; SASSA, R.; ADLER, S.; ETO, N.; KATO, H.; FUJITA, T.; NANGAKU, M. Erythropoietin induces heme oxygenase-1 expression and attenuates oxidative stress. Biochem. Biophys. Res. Commun., v. 359, n. 4, p. 928-934, 2007. 
136. PALLET, N.; BOUVIER, N.; LEGENDRE, C.; BEAUNE, P.; THERVET, E.; CHOUKROUN, G.; MARTINEZ, F. Antiapoptotic properties of recombinant human erythropoietin protects against tubular cyclosporine toxicity. Pharmacol. Res., v. 61, n. 1, p. 71-75, 2009.

137. BELDI, G.; WU, Y.; SUN, X.; IMAI, M.; ENJYOJI, K.; CSIZMADIA, E.; CANDINAS, D.; ERB, L.; ROBSON, S. C. Regulated catalysis of extracellular nucleotides by vascular CD39/ENTPD1 is required for liver regeneration. Gastroenterology, v. 135, n. 5, p. 1751-1760, 2008.

138. KURELLA, M.; HSIAO, L. L.; YOSHIDA, T.; RANDALL, J. D.; CHOW, G.; SARANG, S. S.; JENSEN, R. V.; GULLANS, S. R. DNA microarray analysis of complex biologic processes. J. Am. Soc. Nephrol., v. 12, n. 5, p. 1072-1078, 2001.

139. FEITOZA, C. Q.; SEMEDO, P.; GONCALVES, G. M.; CENEDEZE, M. A.; PINHEIRO, H. S.; DOS SANTOS, O. F.; LANDGRAF, R. G.; PACHECO-SILVA, A.; CAMARA, N. O. Modulation of inflammatory response by selective inhibition of cyclooxygenase-1 and cyclooxygenase-2 in acute kidney injury. Inflamm. Res., v. 59, n. 3, p. 167-175, 2010.

140. FOUGERAY, S.; BOUVIER, N.; BEAUNE, P.; LEGENDRE, C.; ANGLICHEAU, D.; THERVET, E.; PALLET, N. Metabolic stress promotes renal tubular inflammation by triggering the unfolded protein response. Cell Death Dis., v. 2, n. p. e143, 2011.

141. ECKLE, T.; HARTMANN, K.; BONNEY, S.; REITHEL, S.; MITTELBRONN, M.; WALKER, L. A.; LOWES, B. D.; HAN, J.; BORCHERS, C. H.; BUTTRICK, P. M.; KOMINSKY, D. J.; COLGAN, S. P.; ELTZSCHIG, H. K. Adora2b-elicited Per2 stabilization promotes a HIF-dependent metabolic switch crucial for myocardial adaptation to ischemia. Nat. Med., v. 18, n. 5, p. 774-782, 2012.

142. HASCHEMI, A.; WAGNER, O.; MARCULESCU, R.; WEGIEL, B.; ROBSON, S. C.; GAGLIANI, N.; GALlO, D.; CHEN, J. F.; BACH, F. H.; OTTERBEIN, L. E. Crossregulation of carbon monoxide and the adenosine A2a receptor in macrophages. J. Immunol., v. 178, n. 9, p. 5921-5929, 2007.

143. SOUZA, A. C.; VOLPINI, R. A.; SHIMIZU, M. H.; SANCHES, T. R.; CAMARA, N. O.; SEMEDO, P.; RODRIGUES, C. E.; SEGURO, A. C.; ANDRADE, L. Erythropoietin prevents sepsis-related acute kidney injury in rats by inhibiting NF-kappaB and upregulating endothelial nitric oxide synthase. Am. J. Physiol. Renal Physiol., v. 302, n. 8, p. F10451054, 2012.

144. SHERIDAN, A. M.; BONVENTRE, J. V. Cell biology and molecular mechanisms of injury in ischemic acute renal failure. Curr. Opin. Nephrol. Hypertens., v. 9, n. 4, p. 427 434, 2000.

145. DENG, J.; LU, P. D.; ZHANG, Y.; SCHEUNER, D.; KAUFMAN, R. J.; SONENBERG, N.; HARDING, H. P.; RON, D. Translational repression mediates activation of nuclear factor kappa B by phosphorylated translation initiation factor 2. Mol. Cell Biol., v. 24, n. 23, p. 10161-10168, 2004. 
146. HU, P.; HAN, Z.; COUVILlON, A. D.; KAUFMAN, R. J.; EXTON, J. H. Autocrine tumor necrosis factor alpha links endoplasmic reticulum stress to the membrane death receptor pathway through IRE1alpha-mediated NF-kappaB activation and down-regulation of TRAF2 expression. Mol. Cell Biol., v. 26, n. 8, p. 3071-3084, 2006.

147. URANO, F.; WANG, X.; BERTOLOTTI, A.; ZHANG, Y.; CHUNG, P.; HARDING, H. P.; RON, D. Coupling of stress in the ER to activation of JNK protein kinases by transmembrane protein kinase IRE1. Science, v. 287, n. 5453, p. 664-666, 2000.

148. WU, S.; TAN, M.; HU, Y.; WANG, J. L.; SCHEUNER, D.; KAUFMAN, R. J. Ultraviolet light activates NFkappaB through translational inhibition of IkappaBalpha synthesis. J. Biol. Chem., v. 279, n. 33, p. 34898-34902, 2004.

149. INAGI, R. Endoplasmic reticulum stress as a progression factor for kidney injury. Curr. Opin. Pharmacol., v. 10, n. 2, p. 156-165, 2010.

150. VAN DEN BEUCKEN, T.; KORITZINSKY, M.; WOUTERS, B. G. Translational control of gene expression during hypoxia. Cancer Biol. Ther., v. 5, n. 7, p. 749-755, 2006.

151. GARDNER, B. M.; PINCUS, D.; GOTTHARDT, K.; GALLAGHER, C. M.; WALTER, P. Endoplasmic reticulum stress sensing in the unfolded protein response. Cold Spring Harb. Perspect. Biol., v. 5, n. 3, p. a013169, 2013.

152. YEH, C. H.; HSU, S. P.; YANG, C. C.; CHIEN, C. T.; WANG, N. P. Hypoxic preconditioning reinforces HIF-alpha-dependent HSP70 signaling to reduce ischemic renal failure-induced renal tubular apoptosis and autophagy. Life Sci., v. 86, n. 3-4, p. 115-123, 2010.

153. MONTIE, H. L.; KAYALI, F.; HAEZEBROUCK, A. J.; ROSSI, N. F.; DEGRACIA, D. $\mathrm{J}$. Renal ischemia and reperfusion activates the eIF 2 alpha kinase PERK. Biochim. Biophys. Acta, v. 1741, n. 3, p. 314-324, 2005.

154. MORI, K. Tripartite management of unfolded proteins in the endoplasmic reticulum. Cell, v. 101, n. 5, p. 451-454, 2000.

155. KUZNETSOV, G.; BUSH, K. T.; ZHANG, P. L.; NIGAM, S. K. Perturbations in maturation of secretory proteins and their association with endoplasmic reticulum chaperones in a cell culture model for epithelial ischemia. Proc. Natl. Acad. Sci. U S A, v. 93, n. 16, p. 8584-8589, 1996.

156. GONCALVES, G. M.; CENEDEZE, M. A.; FEITOZA, C. Q.; WANG, P. M.; BERTOCCHI, A. P.; DAMIAO, M. J.; PINHEIRO, H. S.; ANTUNES TEIXEIRA, V. P.; DOS REIS, M. A.; PACHECO-SILVA, A.; CAMARA, N. O. The role of heme oxygenase 1 in rapamycin-induced renal dysfunction after ischemia and reperfusion injury. Kidney Int., v. 70, n. 10, p. 1742-1749, 2006.

157. BREWER, J. W.; DIEHL, J. A. PERK mediates cell-cycle exit during the mammalian unfolded protein response. Proc. Natl. Acad. Sci. U S A, v. 97, n. 23, p. 12625-12630, 2000. 
158. BREWER, J. W.; HENDERSHOT, L. M.; SHERR, C. J.; DIEHL, J. A. Mammalian unfolded protein response inhibits cyclin D1 translation and cell-cycle progression. Proc. Natl. Acad. Sci. U S A, v. 96, n. 15, p. 8505-8510, 1999.

159. DONIZETTI-OLIVEIRA, C.; SEMEDO, P.; BURGOS-SILVA, M.; CENEDEZE, M.; MALHEIROS, D.M.C.; REIS, M.A.; PACHECO-SILVA, A.; CAMARA, N.O. Adipose tissue-derived stem cell treatment prevents renal disease progression. Cell Transplantation, v. n. p. in press, 2011.

160. FEITOZA, C. Q.; GONCALVES, G. M.; BERTOCCHI, A. P.; WANG, P. W.; DAMIAO, M. J.; CENEDEZE, M. A.; TEIXEIRA, V. P.; DOS REIS, M. A.; PACHECOSILVA, A.; CAMARA, N. O. A role for HO-1 in renal function impairment in animals subjected to ischemic and reperfusion injury and treated with immunosuppressive drugs. Transplant. Proc., v. 39, n. 2, p. 424-426, 2007.

161. SEMEDO, P.; DONIZETTI-OLIVEIRA, C.; BURGOS-SILVA, M.; CENEDEZE, M. A.; AVANCINI COSTA MALHEIROS, D. M.; PACHECO-SILVA, A.; CAMARA, N. O. Bone marrow mononuclear cells attenuate fibrosis development after severe acute kidney injury. Lab. Invest., v. 90, n. 5, p. 685-695, 2010.

162. FERENBACH, D. A.; KLUTH, D. C.; HUGHES, J. Hemeoxygenase-1 and renal ischaemia-reperfusion injury. Nephron Exp. Nephrol., v. 115, n. 3, p. e33-37, 2010.

163. YANG, H.; LI, H.; WANG, Z.; SHI, Y.; JIANG, G.; ZENG, F. Exendin-4 ameliorates renal ischemia-reperfusion injury in the rat. J. Surg. Res., v. n. p. 2013.

164. SHOKEIR, A. A.; HUSSEIN, A. M.; BARAKAT, N.; ABDELAZIZ, A.; ELGARB, M.; AWADALLA, A. Activation of Nuclear factor (erythroid 2-like)-Related Factor 2 (Nrf2) and Nrf-2 dependent genes by ischemic preconditioning and postconditioning: New Adaptive Endogenous Protective Responses against Renal Ischemia/Reperfusion Injury. Acta Physiol. (Oxf), v. n. p. 2013.

165. ZAGER, R. A.; JOHNSON, A. C.; BECKER, K. Plasma and urinary heme oxygenase-1 in AKI. J. Am. Soc. Nephrol., v. 23, n. 6, p. 1048-1057, 2012.

166. KOTSCH, K.; MARTINS, P. N.; KLEMZ, R.; JANSSEN, U.; GERSTMAYER, B.; DERNIER, A.; REUTZEL-SELKE, A.; KUCKELKORN, U.; TULLIUS, S. G.; VOLK, H. D. Heme oxygenase-1 ameliorates ischemia/reperfusion injury by targeting dendritic cell maturation and migration. Antioxid. Redox Signal., v. 9, n. 12, p. 2049-2063, 2007.

167. FERENBACH, D. A.; RAMDAS, V.; SPENCER, N.; MARSON, L.; ANEGON, I.; HUGHES, J.; KLUTH, D. C. Macrophages expressing heme oxygenase-1 improve renal function in ischemia/reperfusion injury. Mol. Ther., v. 18, n. 9, p. 1706-1713, 2010.

168. FERENBACH, D. A.; NKEJABEGA, N. C.; MCKAY, J.; CHOUDHARY, A. K.; VERNON, M. A.; BEESLEY, M. F.; CLAY, S.; CONWAY, B. C.; MARSON, L. P.; KLUTH, D. C.; HUGHES, J. The induction of macrophage hemeoxygenase-1 is protective during acute kidney injury in aging mice. Kidney Int., v. 79, n. 9, p. 966-976, 2011. 
169. VERA, T.; HENEGAR, J. R.; DRUMMOND, H. A.; RIMOLDI, J. M.; STEC, D. E. Protective effect of carbon monoxide-releasing compounds in ischemia-induced acute renal failure. J. Am. Soc. Nephrol., v. 16, n. 4, p. 950-958, 2005.

170. FALEO, G.; NETO, J. S.; KOHMOTO, J.; TOMIYAMA, K.; SHIMIZU, H.; TAKAHASHI, T.; WANG, Y.; SUGIMOTO, R.; CHOI, A. M.; STOLZ, D. B.; CARRIERI, G.; MCCURRY, K. R.; MURASE, N.; NAKAO, A. Carbon monoxide ameliorates renal cold ischemia-reperfusion injury with an upregulation of vascular endothelial growth factor by activation of hypoxia-inducible factor. Transplantation, v. 85, n. 12, p. 1833-1840, 2008.

171. HANTO, D. W.; MAKI, T.; YOON, M. H.; CSIZMADIA, E.; CHIN, B. Y.; GALLO, D.; KONDURU, B.; KURAMITSU, K.; SMITH, N. R.; BERSSENBRUGGE, A.; ATTANASIO, C.; THOMAS, M.; WEGIEL, B.; OTTERBEIN, L. E. Intraoperative administration of inhaled carbon monoxide reduces delayed graft function in kidney allografts in Swine. Am. J. Transplant., v. 10, n. 11, p. 2421-2430, 2010.

172. CAUMARTIN, Y.; STEPHEN, J.; DENG, J. P.; LIAN, D.; LAN, Z.; LIU, W.; GARCIA, B.; JEVNIKAR, A. M.; WANG, H.; CEPINSKAS, G.; LUKE, P. P. Carbon monoxide-releasing molecules protect against ischemia-reperfusion injury during kidney transplantation. Kidney Int., v. 79, n. 10, p. 1080-1089, 2011.

173. BEN-ARI, Z.; ISSAN, Y.; KATZ, Y.; SULTAN, M.; SAFRAN, M.; MICHAL, L. S.; NADER, G. A.; KORNOWSKI, R.; GRIEF, F.; PAPPO, O.; HOCHHAUSER, E. Induction of heme oxygenase-1 protects mouse liver from apoptotic ischemia/reperfusion injury. Apoptosis, v. 18, n. 5, p. 547-555, 2013.

174. KIM, K. M.; PAE, H. O.; ZHENG, M.; PARK, R.; KIM, Y. M.; CHUNG, H. T. Carbon monoxide induces heme oxygenase-1 via activation of protein kinase R-like endoplasmic reticulum kinase and inhibits endothelial cell apoptosis triggered by endoplasmic reticulum stress. Circ. Res., v. 101, n. 9, p. 919-927, 2007.

175. ZHENG, M.; KIM, S. K.; JOE, Y.; BACK, S. H.; CHO, H. R.; KIM, H. P.; IGNARRO, L. J.; CHUNG, H. T. Sensing endoplasmic reticulum stress by protein kinase RNA-like endoplasmic reticulum kinase promotes adaptive mitochondrial DNA biogenesis and cell survival via heme oxygenase-1/carbon monoxide activity. Faseb J., v. 26, n. 6, p. 2558-2568, 2012.

176. CHUNG, J.; SHIN, D. Y.; ZHENG, M.; JOE, Y.; PAE, H. O.; RYTER, S. W.; CHUNG, H. T. Carbon monoxide, a reaction product of heme oxygenase-1, suppresses the expression of C-reactive protein by endoplasmic reticulum stress through modulation of the unfolded protein response. Mol. Immunol., v. 48, n. 15-16, p. 1793-1799, 2011.

177. PITTOCK, S. T.; NORBY, S. M.; GRANDE, J. P.; CROATT, A. J.; BREN, G. D.; BADLEY, A. D.; CAPLICE, N. M.; GRIFFIN, M. D.; NATH, K. A. MCP-1 is up-regulated in unstressed and stressed HO-1 knockout mice: Pathophysiologic correlates. Kidney Int., v. 68, n. 2, p. 611-622, 2005.

178. WAGENER, F. A.; VOLK, H. D.; WILLIS, D.; ABRAHAM, N. G.; SOARES, M. P.; ADEMA, G. J.; FIGDOR, C. G. Different faces of the heme-heme oxygenase system in inflammation. Pharmacol. Rev., v. 55, n. 3, p. 551-571, 2003. 
179. YANG, J.; ZHOU, Y.; GUAN, Y. PPARgamma as a therapeutic target in diabetic nephropathy and other renal diseases. Curr. Opin. Nephrol. Hypertens., v. 21, n. 1, p. 97 $105,2012$.

180. PARK, S. H.; CHOI, H. J.; YANG, H.; DO, K. H.; KIM, J.; LEE, D. W.; MOON, Y. Endoplasmic reticulum stress-activated C/EBP homologous protein enhances nuclear factorkappaB signals via repression of peroxisome proliferator-activated receptor gamma. J. Biol. Chem., v. 285, n. 46, p. 35330-35339, 2010.

181. ZUCKERBRAUN, B. S.; CHIN, B. Y.; BILBAN, M.; D'AVILA, J. C.; RAO, J.; BILLIAR, T. R.; OTTERBEIN, L.E. Carbon monoxide signals via inhibition of cytochrome c oxidase and generation of mitochondrial reactive oxygen species. Faseb J., v. 21, n. 4, p. 1099-1106, 2007.

182. SULIMAN, H. B.; CARRAWAY, M. S.; TATRO, L. G.; PIANTADOSI, C. A. A new activating role for $\mathrm{CO}$ in cardiac mitochondrial biogenesis. J. Cell Sci., v. 120, n. Pt 2, p. 299$308,2007$.

183. LEE, T. S.; CHAU, L. Y. Heme oxygenase-1 mediates the anti-inflammatory effect of interleukin-10 in mice. Nat. Med., v. 8, n. 3, p. 240-246, 2002.

184. PIANTADOSI, C. A.; WITHERS, C. M.; BARTZ, R. R.; MACGARVEY, N. C.; FU, P.; SWEENEY, T. E.; WELTY-WOLF, K. E.; SULIMAN, H. B. Heme oxygenase-1 couples activation of mitochondrial biogenesis to anti-inflammatory cytokine expression. J. Biol. Chem., v. 286, n. 18, p. 16374-16385, 2011.

185. WU, X. D.; ZHANG, Z. Y.; SUN, S.; LI, Y. Z.; WANG, X. R.; ZHU, X. Q.; LI, W. H.; LIU, X. H. Hypoxic preconditioning protects microvascular endothelial cells against hypoxia/reoxygenation injury by attenuating endoplasmic reticulum stress. Apoptosis, v. 18, n. 1, p. 85-98, 2013.

186. OTTERBEIN, L. E.; BACH, F. H.; ALAM, J.; SOARES, M.; TAO LU, H.; WYSK, M.; DAVIS, R. J.; FLAVELL, R. A.; CHOI, A. M. Carbon monoxide has anti-inflammatory effects involving the mitogen-activated protein kinase pathway. Nat. Med., v. 6, n. 4, p. 422$428,2000$.

187. ZHANG, X.; SHAN, P.; OTTERBEIN, L. E.; ALAM, J.; FLAVELL, R. A.; DAVIS, R. J.; CHOI, A. M.; LEE, P. J. Carbon monoxide inhibition of apoptosis during ischemiareperfusion lung injury is dependent on the p38 mitogen-activated protein kinase pathway and involves caspase 3. J. Biol. Chem., v. 278, n. 2, p. 1248-1258, 2003.

188. HUALIN, C.; WENLI, X.; DAPENG, L.; XIJING, L.; XIUHUA, P.; QINGFENG, P. The anti-inflammatory mechanism of heme oxygenase- 1 induced by hemin in primary rat alveolar macrophages. Inflammation, v. 35, n. 3, p. 1087-1093, 2012.

189. CHEN, X. Q.; WU, S. H.; ZHOU, Y.; TANG, Y. R. Lipoxin A4-induced heme oxygenase-1 protects cardiomyocytes against hypoxia/reoxygenation injury via p38 MAPK activation and Nrf2/ARE complex. PLoS One, v. 8, n. 6, p. e67120, 2013. 
190. WANG, J.; YANG, H.; HU, X.; FU, W.; XIE, J.; ZHOU, X.; XU, W.; JIANG, H. Dobutamine-mediated heme oxygenase-1 induction via PI3K and p38 MAPK inhibits high mobility group box 1 protein release and attenuates rat myocardial ischemia/reperfusion injury in vivo. J. Surg. Res., v. 183, n. 2, p. 509-516, 2013.

191. WU, B. J.; CHEN, K.; BARTER, P. J.; RYE, K. A. Niacin inhibits vascular inflammation via the induction of heme oxygenase-1. Circulation, v. 125, n. 1, p. 150-158, 2012.

192. BROUARD, S.; OTTERBEIN, L. E.; ANRATHER, J.; TOBIASCH, E.; BACH, F. H.; CHOI, A. M.; SOARES, M. P. Carbon monoxide generated by heme oxygenase 1 suppresses endothelial cell apoptosis. J. Exp. Med., v. 192, n. 7, p. 1015-1026, 2000.

193. Petrache, I.; OtTerbein, L. E.; AlAM, J.; WiEGAND, G. W.; CHOI, A. M. Heme oxygenase-1 inhibits TNF-alpha-induced apoptosis in cultured fibroblasts. Am. J. Physiol. Lung Cell Mol. Physiol., v. 278, n. 2, p. L312-319, 2000.

194. MORSE, D.; SETHI, J. Carbon monoxide and human disease. Antioxid. Redox Signal., v. 4, n. 2, p. 331-338, 2002.

195. AKCAY, A.; NGUYEN, Q.; EDELSTEIN, C. L. Mediators of inflammation in acute kidney injury. Mediators Inflamm., v. 2009, n. p. 137072, 2009.

196. DUFFIELD, J. S.; ERWIG, L. P.; WEI, X.; LIEW, F. Y.; REES, A. J.; SAVILL, J. S. Activated macrophages direct apoptosis and suppress mitosis of mesangial cells. J. Immunol., v. 164, n. 4, p. 2110-2119, 2000.

197. MISSERI, R.; MELDRUM, D. R.; DINARELlO, C. A.; DAGHER, P.; HILE, K. L.; RINK, R.C.; MELDRUM, K.K. TNF-alpha mediates obstruction-induced renal tubular cell apoptosis and proapoptotic signaling. Am. J. Physiol. Renal Physiol., v. 288, n. 2, p. F406$411,2005$.

198. RYU, M.; KULKARNI, O. P.; RADOMSKA, E.; MIOSGE, N.; GROSS, O.; ANDERS, H. J. Bacterial CpG-DNA accelerates Alport glomerulosclerosis by inducing an M1 macrophage phenotype and tumor necrosis factor-alpha-mediated podocyte loss. Kidney Int., v. 79, n. 2, p. 189-198, 2011.

199. ANDERS, H. J.; RYU, M. Renal microenvironments and macrophage phenotypes determine progression or resolution of renal inflammation and fibrosis. Kidney Int., v. 80, n. 9, p. 915-925, 2011.

200. LIU, G.; MA, H.; QIU, L.; LI, L.; CAO, Y.; MA, J.; ZHAO, Y. Phenotypic and functional switch of macrophages induced by regulatory $\mathrm{CD} 4+\mathrm{CD} 25+\mathrm{T}$ cells in mice. Immunol. Cell Biol., v. 89, n. 1, p. 130-142, 2010.

201. FILARDY, A. A.; PIRES, D. R.; NUNES, M. P.; TAKIYA, C. M.; FREIRE-DE-LIMA, C. G.; RIBEIRO-GOMES, F. L.; DOSREIS, G. A. Proinflammatory clearance of apoptotic neutrophils induces an IL-12(low)IL-10(high) regulatory phenotype in macrophages. J. Immunol., v. 185, n. 4, p. 2044-2050, 2010. 
202. ELTZSCHIG, H. K.; KOHLER, D.; ECKLE, T.; KONG, T.; ROBSON, S .C.; COLGAN, S.P. Central role of Sp1-regulated CD39 in hypoxia/ischemia protection. Blood, v. 113, n. 1, p. 224-232, 2009.

203. WU, N.; SIOW, Y.L.; O, K. Ischemia/reperfusion reduces transcription factor Sp1mediated cystathionine beta-synthase expression in the kidney. J. Biol. Chem., v. 285, n. 24, p. 18225-18233, 2010.

204. LIN, H. H.; LAI, S. C.; CHAU, L. Y. Heme oxygenase-1/carbon monoxide induces vascular endothelial growth factor expression via p38 kinase-dependent activation of Sp1. J. Biol. Chem., v. 286, n. 5, p. 3829-3838, 2011.

205. LIAO, H.; HYMAN, M. C.; BAEK, A. E.; FUKASE, K.; PINSKY, D. J. cAMP/CREBmediated transcriptional regulation of ectonucleoside triphosphate diphosphohydrolase 1 (CD39) expression. J. Biol. Chem., v. 285, n. 19, p. 14791-14805, 2010.

206. SZOLECZKY, P.; MODIS, K.; NAGY, N.; DORI TOTH, Z.; DEWITT, D.; SZABO, C.; GERO, D. Identification of agents that reduce renal hypoxia-reoxygenation injury using cell-based screening: purine nucleosides are alternative energy sources in LLC-PK1 cells during hypoxia. Arch. Biochem. Biophys., v. 517, n. 1, p. 53-70, 2012.

207. WEN, A. Y.; SAKAMOTO, K. M.; MILLER, L. S. The role of the transcription factor CREB in immune function. J. Immunol., v. 185, n. 11, p. 6413-6419, 2010.

208. GUNARATNAM, L.; BONVENTRE, J. V. HIF in kidney disease and development. J. Am. Soc. Nephrol., v. 20, n. 9, p. 1877-1887, 2009.

209. BONVENTRE, J. V.; YANG, L. Cellular pathophysiology of ischemic acute kidney injury. J. Clin. Invest., v. 121, n. 11, p. 4210-4221, 2011.

210. HILL, P.; SHUKLA, D.; TRAN, M. G.; ARAGONES, J.; COOK, H. T.; CARMELIET, P.; MAXWELL, P. H. Inhibition of hypoxia inducible factor hydroxylases protects against renal ischemia-reperfusion injury. J. Am. Soc. Nephrol., v. 19, n. 1, p. 39-46, 2008.

211. CHIN, B. Y.; JIANG, G.; WEGIEL, B.; WANG, H. J.; MACDONALD, T.; ZHANG, X. C.; GALLO, D.; CSZIMADIA, E.; BACH, F. H.; LEE, P. J.; OTTERBEIN, L. E. Hypoxiainducible factor 1alpha stabilization by carbon monoxide results in cytoprotective preconditioning. Proc. Natl. Acad. Sci. U S A, v. 104, n. 12, p. 5109-5114, 2007.

212. SCHEIERMANN, C.; KUNISAKI, Y.; FRENETTE, P.S. Circadian control of the immune system. Nat. Rev. Immunol., v. 13, n. 3, p. 190-198, 2013.

213. CAETANO, A. M.; VIANNA FILHO, P. T.; CASTIGLIA, Y. M.; GOLIM, M. A.; DE SOUZA, A. V.; DE CARVALHO, L. R.; DEFFUNE, E.; DE OLIVEIRA, C.; VIANNA, P. T. Erythropoietin attenuates apoptosis after ischemia-reperfusion-induced renal injury in transiently hyperglycemic Wister rats. Transplant. Proc., v. 43, n. 10, p. 3618-3621, 2011.

214. RODRIGUES, C. E.; SANCHES, T. R.; VOLPINI, R. A.; SHIMIZU, M. H.; KURIKI, P. S.; CAMARA, N. O.; SEGURO, A. C.; ANDRADE, L. Effects of continuous 
erythropoietin receptor activator in sepsis-induced acute kidney injury and multi-organ dysfunction. PLoS One, v. 7, n. 1, p. e29893, 2012.

215. HU, L.; YANG, C.; ZHAO, T.; XU, M.; TANG, Q.; YANG, B.; RONG, R.; ZHU, T. Erythropoietin ameliorates renal ischemia and reperfusion injury via inhibiting tubulointerstitial inflammation. J. Surg. Res., v. 176, n. 1, p. 260-266, 2012.

216. CHEN, S. J.; WANG, Y. L.; LO, W. T.; WU, C. C.; HSIEH, C. W.; HUANG, C. F.; LAN, Y. H.; WANG, C. C.; CHANG, D. M.; SYTWU, H. K. Erythropoietin enhances endogenous haem oxygenase-1 and represses immune responses to ameliorate experimental autoimmune encephalomyelitis. Clin. Exp. Immunol., v. 162, n. 2, p. 210-223, 2010.

217. GENC, K.; EGRILMEZ, M. Y.; GENC, S. Erythropoietin induces nuclear translocation of Nrf2 and heme oxygenase-1 expression in SH-SY5Y cells. Cell Biochem. Funct., v. 28, n. 3, p. 197-201, 2010.

218. BURGER, D.; XIANG, F.; HAMMOUD, L.; LU, X.; FENG, Q. Role of heme oxygenase-1 in the cardioprotective effects of erythropoietin during myocardial ischemia and reperfusion. Am. J. Physiol. Heart Circ. Physiol., v. 296, n. 1, p. H84-93, 2009.

219. WEInBERG, J. M. Mitochondrial biogenesis in kidney disease. J. Am. Soc. Nephrol., v. 22, n. 3, p. 431-436, 2011.

220. WILLS, L. P.; TRAGER, R. E.; BEESON, G. C.; LINDSEY, C. C.; PETERSON, Y. K.; BEESON, C. C.; SCHNELLMANN, R. G. The beta2-adrenoceptor agonist formoterol stimulates mitochondrial biogenesis. J. Pharmacol. Exp. Ther., v. 342, n. 1, p. 106-118, 2012.

221. TRAN, M.; TAM, D.; BARDIA, A.; BHASIN, M.; ROWE, G. C.; KHER, A.; ZSENGELLER, Z. K.; AKHAVAN-SHARIF, M. R.; KHANKIN, E. V.; SAINTGENIEZ, M.; DAVID, S.; BURSTEIN, D.; KARUMANCHI, S. A.; STILLMAN, I. E.; ARANY, Z.; PARIKH, S. M. PGC-1alpha promotes recovery after acute kidney injury during systemic inflammation in mice. J. Clin. Invest., v. 121, n. 10, p. 4003-4014, 2011.

222. PIANTADOSI, C. A.; SULIMAN, H. B. Redox regulation of mitochondrial biogenesis. Free Radic. Biol. Med., v. 53, n. 11, p. 2043-2053, 2012.

223. WEGIEL, B.; CHIN, B. Y.; OTTERBEIN, L. E. Inhale to survive, cycle or die? Carbon monoxide and cellular proliferation. Cell Cycle, v. 7, n. 10, p. 1379-1384, 2008. 
APENNDICE 


\section{Artigos publicados ou enviados para publicação durante o doutorado}

Durante o período do doutorado, entre setembro de 2009 e setembro de 2013, o aluno publicou 13 artigos científicos, na condição de primeiro autor ou co-autor. Ainda, o mesmo tem 4 artigos enviados para publicação, ainda em fase de revisão, nas revistas Laboratory Investigation (PAFR and renal fibrosis), British Journal of Pharmacology (Leptin and LPS), Journal of Molecular Medicine (iNKT and tubulointerstitial nephritis) e Antioxidants \& Redox Signaling (Heme Oxygenase-1: a metabolic nike). Os artigos encontram-se ilustrados nas páginas seguintes. 


\title{
Tissue-Specific Stem Cells
}

\section{Mesenchymal Stem Cells Attenuate Renal Fibrosis Through Immune Modulation and Remodeling Properties in a Rat Remnant Kidney Model}

\author{
Patricia Semedo, ${ }^{a}$ Matheus Correa-Costa, ${ }^{\text {a }}$ Marcos Antonio Cenedeze, \\ Denise Maria Avancini Costa Malheiros, ${ }^{b}$ Marlene Antonia dos Reis, ${ }^{\text {c }}$ Maria Heloisa Shimizu, \\ antonio Carlos Seguro, ${ }^{d}$ Alvaro Pacheco-Silva, a,e Niels Olsen Saraiva Camara, \\ ${ }^{\mathrm{a}}$ Nephrology Division, Medicine Department, Federal University of São Paulo, São Paulo, Brazil; ${ }^{\mathrm{b}}$ Pathology \\ Department, São Paulo University, São Paulo, Brazil; ' General Pathology Division, Triângulo Mineiro Medical \\ School, Minas Gerais, Brazil; ' Department of Nephrology, University of São Paulo School of Medicine, \\ São Paulo, Brazil; ${ }^{\circledR}$ IIEP, Albert Einstein Hospital, São Paulo, SP, Brazil; ${ }^{f}$ Laboratory of Transplantation \\ Immunobiology, Department of Immunology, University of São Paulo, São Paulo, Brazil
}

Key Words. Mesenchymal stem cell • Ischemia-reperfusion injury • Fibrosis $\bullet$ Chronic renal failure $\bullet$ Kidney fibrosis

\begin{abstract}
Mesenchymal stem cells (MSCs) have regenerative properties in acute kidney injury, but their role in chronic kidney diseases is still unknown. More specifically, it is not known whether MSCs halt fibrosis. The purpose of this work was to investigate the role of MSCs in fibrogenesis using a model of chronic renal failure. MSCs were obtained from the tibias and femurs of male Wistar-EPM rats. Female Wistar rats were subjected to the remnant model, and $2|\times| 10^{5}$ MSCs were intravenously administrated to each rat every other week for 8 weeks or only once and followed for 12 weeks. SRY gene expression was observed in female rats treated with male MSCs, and immune localization of $\mathrm{CD} 73^{+} \mathrm{CD}^{+}{ }^{+}$cells at 8 weeks was also assessed. Serum and urine analyses showed an amelioration of functional parameters in MSC-treated animals at 8 weeks, but not at 12 weeks. Masson's trichrome and Sirius red staining demonstrated

reduced levels of fibrosis in MSC-treated animals. These results were corroborated by reduced vimentin, type I collagen, transforming growth factor $\beta$, fibroblast specific protein 1 (FSP-1), monocyte chemoattractant protein 1, and Smad3 mRNA expression and $\alpha$ smooth muscle actin and FSP-1 protein expression. Renal interleukin (IL)-6 and tumor necrosis factor $\alpha$ mRNA expression levels were significantly decreased after MSC treatment, whereas IL-4 and IL-10 expression levels were increased. All serum cytokine expression levels were decreased in MSC-treated animals. Taken together, these results suggested that MSC therapy can indeed modulate the inflammatory response that follows the initial phase of a chronic renal injury. The immunosuppressive and remodeling properties of MSCs may be involved in the decreased fibrosis in the kidney. STEM CELLS 2009; 27:3063-3073
\end{abstract}

Disclosure of potential conflicts of interest is found at the end of this article.

\section{INTRODUCTION}

Chronic kidney disease (CKD) is a worldwide health problem, and the number of affected individuals is steadily increasing over time [1, 2]. In 2008, World Kidney Day heralded this disease as a global public health threat.

Most CKD basic studies are performed with experimental models, such as the remnant model, also termed 5/6 nephrectomy $(\mathrm{Nx})$, which was originally described by Shimamura and Morrison [3]. The progression of renal disease in the remnant model is characterized by the development of glomerulosclerosis and interstitial fibrosis $[4,5]$. The reduction of nephron mass leads to hypertrophy, hyperfiltration, glomerular and systemic hypertension, and thus, glomerulosclerosis [6]. Several factors are implicated in the initiation of this cascade, such as angiotensin II, growth factors, cytokines, oxygen metabolites, and mechanical factors [6-9]. Inhibition of angiotensin-converting enzymes and a low-protein diet have been demonstrated to reduce intraglomerular pressure and have led to improved results in several experimental animal models [10, $11]$.

Author contributions: P.S.: conception and design, collection and/or assembly of data, data analysis and interpretation, manuscript writing, final approval of manuscript; M.C.-C. and M.A.C.: collection and/or assembly of data, final approval of manuscript; D.M.A.C.M. and M.A.R.: histological analyses, data analysis and interpretation, final approval of manuscript; M.H.S. and A.C.S.: provision of study material, final approval of manuscript; A.P.-S.: administrative support, final approval of manuscript; N.O.S.C.: conception and design, data analysis and interpretation, financial support, final approval of manuscript.

Correspondence: Dr. Niels Olsen Saraiva Ĉamara, Professor, Department of Immunology, Institute of Biomedical Science IV, Universidade de São Paulo, Rua Prof Lineu Prestes, 1730, 05508-900 São Paulo, SP, Brazil. Telephone: 5511-3091-7388; Fax: 5511-3091-7224; e-mail: niels@icb.usp.br Received April 6, 2009; accepted for publication August 21, 2009; first published online in Stem Cells Express September 11, 2009. (C) AlphaMed Press 1066-5099/2009/\$30.00/0 doi: 10.1002/stem.214 


\title{
Induction of Heme Oxygenase-1 Can Halt and Even Reverse Renal Tubule-Interstitial Fibrosis
}

\author{
Matheus Correa-Costa ${ }^{1,2}$, Patricia Semedo ${ }^{1}$, Ana Paula F. S. Monteiro ${ }^{1}$, Reinaldo C. Silva ${ }^{1}$, Rafael L. \\ Pereira ${ }^{1}$, Giselle M. Gonçalves ${ }^{2}$, Georgia Daniela Marcusso Marques' ${ }^{1}$, Marcos A. Cenedeze ${ }^{1}$, Ana C. G. \\ Faleiros $^{3}$, Alexandre C. Keller ${ }^{1}$, Maria H. M. Shimizu ${ }^{4}$, Antônio C. Seguro ${ }^{4}$, Marlene A. Reis ${ }^{3}$, Alvaro \\ Pacheco-Silva ${ }^{1}$, Niels O. S. Câmara ${ }^{1,2 *}$
}

1 Laboratory of Clinical and Experimental Immunology, Nephrology Division, Federal University of São Paulo (UNIFESP), São Paulo, Brazil, 2 Laboratory of Transplantation Immunobiology, Department of Immunology, Institute of Biomedical Sciences IV, University of São Paulo (USP), São Paulo, Brazil, $\mathbf{3}$ Pathology Division, Federal University of Triângulo Mineiro (UFTM), Uberaba, Brazil, 4 Nephrology Department, School of Medicine, University of São Paulo, São Paulo, Brazil

\begin{abstract}
Background: The tubule-interstitial fibrosis is the hallmark of progressive renal disease and is strongly associated with inflammation of this compartment. Heme-oxygenase-1 (HO-1) is a cytoprotective molecule that has been shown to be beneficial in various models of renal injury. However, the role of HO-1 in reversing an established renal scar has not yet been addressed.

Aim: We explored the ability of HO-1 to halt and reverse the establishment of fibrosis in an experimental model of chronic renal disease.

Methods: Sprague-Dawley male rats were subjected to unilateral ureteral obstruction (UUO) and divided into two groups: non-treated and Hemin-treated. To study the prevention of fibrosis, animals were pre-treated with Hemin at days -2 and -1 prior to UUO. To investigate whether HO-1 could reverse established fibrosis, Hemin therapy was given at days 6 and 7 postsurgery. After 7 and/or 14 days, animals were sacrificed and blood, urine and kidney tissue samples were collected for analyses. Renal function was determined by assessing the serum creatinine, inulin clearance, proteinuria/creatininuria ratio and extent of albuminuria. Arterial blood pressure was measured and fibrosis was quantified by Picrosirius staining. Gene and protein expression of pro-inflammatory and pro-fibrotic molecules, as well as HO-1 were performed.
\end{abstract}

Results: Pre-treatment with Hemin upregulated HO-1 expression and significantly reduced proteinuria, albuminuria, inflammation and pro-fibrotic protein and gene expressions in animals subjected to UUO. Interestingly, the delayed treatment with Hemin was also able to reduce renal dysfunction and to decrease the expression of pro-inflammatory molecules, all in association with significantly reduced levels of fibrosis-related molecules and collagen deposition. Finally, TGF- $\beta$ protein production was significantly lower in Hemin-treated animals.

Conclusion: Treatment with Hemin was able both to prevent the progression of fibrosis and to reverse an established renal scar. Modulation of inflammation appears to be the major mechanism behind HO-1 cytoprotection.

Citation: Correa-Costa M, Semedo P, Monteiro APFS, Silva RC, Pereira RL, et al. (2010) Induction of Heme Oxygenase-1 Can Halt and Even Reverse Renal TubuleInterstitial Fibrosis. PLoS ONE 5(12): e14298. doi:10.1371/journal.pone.0014298

Editor: Christos Chatziantoniou, Inserm, France

Received April 18, 2010; Accepted November 23, 2010; Published December 13, 2010

Copyright: (c) 2010 Correa-Costa et al. This is an open-access article distributed under the terms of the Creative Commons Attribution License, which permits unrestricted use, distribution, and reproduction in any medium, provided the original author and source are credited.

Funding: This work was supported by Fundacao de Amparo Pesquisa do Estado de Sao Paulo-FAPESP (07/07139-3), Coordenaco de Aperfeioamento de Pessoal de Nivel Superior-CAPES, Instituto Nacional de Ciência e Tecnologia de Complexos Fluidos and Conselho Nacional de Desenvolvimento Cientifico e TecnologicoCNPq. The funders had no role in study design, data collection and analysis, decision to publish, or preparation of the manuscript.

Competing Interests: The authors have declared that no competing interests exist.

* E-mail: niels@icb.usp.br

\section{Introduction}

The tubule-interstitial space plays an important role in the progression of chronic renal diseases [1]. Tubule-interstitial changes, including tubular degeneration and interstitial cell infiltration, are a hallmark of common progressive chronic diseases that lead to renal failure [2].

A well-characterized experimental model of renal injury that leads to tubule-interstitial fibrosis is the unilateral ureteral obstruction (UUO). The obstruction of urinary flow leads to release of chemoattractant molecules and growth factors, upregu- lation of adhesion proteins and degradation of basement membrane matrix proteins [3]. Moreover, a few hours after the obstruction of urine flow, blood-derived macrophages accumulate in the tubule-interstitial space (in healthy renal cortex, the presence of these cells is rare). This cellular infiltration is driven by local expression of molecules such as monocyte chemoattractant protein-1 (MCP-1) and osteopontin [4]. Infiltrating cells release pro-inflammatory cytokines such as TNF- $\alpha$, IL- 6 and IL$1 \beta$ that activate resident fibroblasts and epithelial tubular cells to initiate the process of epithelial-to-mesenchymal transition (EMT), a process in which polarized epithelial cells undergo biochemical 


\section{Bradykinin receptor 1 activation exacerbates experimental focal and segmental glomerulosclerosis}

Rafael L. Pereira ${ }^{1}$, Bruna N. Buscariollo', Matheus Corrêa-Costa², Patricia Semedo', Cassiano D. Oliveira', Vanessa O. Reis ${ }^{1}$, Edgar Maquigussa ${ }^{3}$, Ronaldo C. Araújo ${ }^{4}$, Tárcio T. Braga ${ }^{2}$, Maria F. Soares ${ }^{5}$, Ivan C. Moura ${ }^{6}$, Denise M.A.C. Malheiros ${ }^{7}$, Alvaro Pacheco-Silva Filho ${ }^{1,8}$, Alexandre C. Keller ${ }^{1,9}$ and Niels O.S. Câmara ${ }^{1,2}$

${ }^{7}$ Departamento de Medicina, Laboratório de Imunologia Clínica e Experimental, Disciplina de Nefrologia, Universidade Federal de São Paulo, São Paulo, Brazil; ${ }^{2}$ Laboratório de Imunobiologia de Transplante, Departamento de Imunologia, Universidade de São Paulo, São Paulo, Brazil; ${ }^{3}$ Departamento de Medicina, Laboratório de Biologia Molecular, Disciplina de Nefrologia, Universidade Federal de São Paulo, São Paulo, Brazil; ${ }^{4}$ Departamento de Biofísica, Universidade Federal de São Paulo, São Paulo, Brazil; ${ }^{5}$ Departamento de Patologia, Universidade Federal de São Paulo, São Paulo, Brazil; INSERM U699, Immunopathologie rénale, récepteurs et inflammation, Faculté de Médecine Xavier Bichat, Paris, France, ${ }^{7}$ Departamento de Patologia, Universidade de São Paulo, São Paulo, Brazil; ${ }^{8} \mathrm{Hospital}$ Israelita Albert Einstein, São Paulo, Brazil and ${ }^{9}$ Departamento de Microbiologia, Imunologia e Parasitologia, Universidade Federal de São Paulo, São Paulo, Brazil

Focal and segmental glomerulosclerosis (FSGS) is one of the most important causes of end-stage renal failure. The bradykinin $\mathrm{B} 1$ receptor has been associated with tissue inflammation and renal fibrosis. To test for a role of the bradykinin B1 receptor in podocyte injury, we pharmacologically modulated its activity at different time points in an adriamycin-induced mouse model of FSGS. Estimated albuminuria and urinary protein to creatinine ratios correlated with podocytopathy. Adriamycin injection led to loss of body weight, proteinuria, and upregulation of B1 receptor mRNA. Early treatment with a B1 antagonist reduced albuminuria and glomerulosclerosis, and inhibited the adriamycin-induced downregulation of podocin, nephrin, and $\alpha$-actinin- 4 expression. Moreover, delayed treatment with antagonist also induced podocyte protection. Conversely, a B1 agonist aggravated renal dysfunction and even further suppressed the levels of podocyte-related molecules. Thus, we propose that kinin has a crucial role in the pathogenesis of FSGS operating through bradykinin B1 receptor signaling.

Kidney International (2011) 79, 1217-1227; doi:10.1038/ki.2011.14; published online 16 March 2011

KEYWORDS: bradykinin B1 receptor; focal and segmental glomerulosclerosis; kinin; podocyte

Correspondence: Niels O. S. Câmara, Department of Immunology, Institute of Biomedical Science IV, Universidade de São Paulo, Rua Prof Lineu Prestes, 1730, 05508-900 São Paulo, São Paulo, Brazil or Disciplina de Nefrologia, Universidade Federal de São Paulo, Rua Pedro de Toledo 720, Vila Clementino 04023-900, São Paulo, São Paulo, Brazil.E-mail: niels@icb.usp.br or niels@nefro.epm.br

Received 10 May 2010; revised 9 December 2010; accepted 21 December 2010; published online 16 March 2011
Focal and segmental glomerulosclerosis (FSGS) is one of the most important causes of end-stage renal failure. ${ }^{1,2}$ FSGS is characterized by areas of glomerular sclerosis associated with tubular atrophy and interstitial fibrosis with commitment of the podocytes that lead to proteinuria. ${ }^{3}$ Podocytes are polarized cells that possess a cytoskeleton that modulates their foot processes that adhere to the glomerular basement membrane. ${ }^{4,5}$ The foot processes are linked laterally by negative charge structures named slit diaphragms, ${ }^{5}$ that are an important filtration barrier composed of many proteins like nephrin (NPHS-1), NEPH-1, podocin (NPHS-2), CD2AP, ZO- 1 , and $\alpha$-actinin- $4 .{ }^{4,6,7}$

Recently, some experimental data demonstrated a protective role of bradykinin blockade in acute and chronic kidney injury models. ${ }^{8}$ Bradykinin signals through two G-proteincoupled receptors, the B1 (B1RBK) and B2 (B2RBK) receptors. B2RBK is constitutively expressed in most tissues and mediates the majority of the physiological actions of kinins. On the other hand, B1RBK is overexpressed in inflammatory conditions. ${ }^{9,10}$ The absence or blockade of B1RBK is generally protective in renal disease models. ${ }^{8,11-13}$ Nevertheless, the role of B1RBK in FSGS is still unclear. Here, we hypothesize that B1RBK also plays an important role in podocytopathy, which is a hallmark of FSGS. Blocking B1RBK signaling could be a new strategy to halt the progression of FSGS and prevent end-stage renal disease.

\section{RESULTS}

Bradykinin receptors are upregulated in an adriamycin-induced FSGS model

FSGS was induced in BALB/c mice ${ }^{14,15}$ by a single intravenous injection of adriamycin. The adriamycin-induced nephropathy model is a model of FSGS that mimics many features of human disease. The animals 


\title{
Formaldehyde induces lung inflammation by an oxidant and antioxidant enzymes mediated mechanism in the lung tissue
}

\author{
Adriana Lino-dos-Santos-Franco ${ }^{a}$, Matheus Correa-Costa ${ }^{b}$, Ana Carolina Cardoso dos Santos Durão ${ }^{c}$, \\ Ana Paula Ligeiro de Oliveira ${ }^{b}$, Ana Cristina Breithaupt-Faloppa ${ }^{a}$, Jônatas de Almeida Bertoni ${ }^{a}$, \\ Ricardo Martins Oliveira-Filho ${ }^{a}$, Niels Olsen Saraiva Câmara ${ }^{b}$, Tânia Marcourakis ${ }^{c}$, \\ Wothan Tavares-de-Lima ${ }^{\mathrm{a}, *}$
}

a Department of Pharmacology, Institute of Biomedical Sciences, University of São Paulo, São Paulo, Brazil

${ }^{\mathrm{b}}$ Department of Immunology, Institute of Biomedical Sciences, University of São Paulo, São Paulo, Brazil

c Department of Clinical and Toxicological Analyses, Faculty of Pharmaceutical Sciences, University of São Paulo, São Paulo, Brazil

\section{A R T I C L E I N F O}

\section{Article history:}

Received 15 July 2011

Received in revised form

23 September 2011

Accepted 24 September 2011

Available online 1 October 2011

\section{Keywords:}

Formaldehyde

Lung inflammation

Inflammatory mediators

Reactive oxygen and nitrogen species

Oxidants and anti-oxidant enzymes

\begin{abstract}
A B S T R A C T
Formaldehyde (FA) is an indoor and outdoor pollutant widely used by many industries, and its exposure is associated with inflammation and oxidative stress in the airways. Our previous studies have demonstrated the role of reactive oxygen species (ROS) in lung inflammation induced by FA inhalation but did not identify source of the ROS. In the present study, we investigate the effects of FA on the activities and gene expression of glutathione peroxidase (GPX), glutathione reductase (GR), glutathione S-transferase (GST), superoxide dismutase (SOD) 1 and 2, catalase (CAT), nitric oxide synthase (iNOS and cNOS) and cyclooxygenase (COX) 1 and 2. The hypothesized link between NADPH-oxidase, nitric oxide synthase and cyclooxygenase, the lung inflammation after FA inhalation was also investigated. For experiments, male Wistar rats were submitted to FA inhalation (1\%, 90 min daily) for 3 consecutive days. The treatments with apocynin and indomethacin before the FA exposure reduced the number of neutrophils recruited into the lung. Moreover, the treatments with apocynin and indomethacin blunted the effect of FA on the generation of IL-1 $\beta$, while the treatments with L-NAME and apocynin reduced the generation of IL- 6 by lung explants when compared to the untreated group. FA inhalation increased the levels of NO and hydrogen peroxide by BAL cells cultured and the treatments with apocynin and L-NAME reduced these generations. FA inhalation did not modify the activities of GPX, GR, GST and CAT but reduced the activity of SOD when compared to the naïve group. Significant increases in SOD-1 and -2, CAT, iNOS, cNOS and COX-1 expression were observed in the FA group compared to the naïve group. The treatments with apocynin, indomethacin and L-NAME reduced the gene expression of antioxidant and oxidant enzymes. In conclusion, our results indicate that FA causes a disruption of the physiological balance between oxidant and antioxidant enzymes in lung tissue, most likely favoring the oxidant pathways and thus positively modulating lung inflammation.
\end{abstract}

(c) 2011 Elsevier Ireland Ltd. All rights reserved.

\section{Introduction}

Formaldehyde (FA) is a common environmental pollutant and its exposure causes occupational and environmental health problems (Mendell and Heath, 2005; Delfino, 2002). FA is found in many products including disinfectants, cosmetics, antiseptics and fungicides (Carlson et al., 2004). It is also used in the manufacture of plastics,

\footnotetext{
* Corresponding author at: Laboratório de Fisiopatologia da Inflamação Experimental, Instituto de Ciências Biomédicas, University of São Paulo, Av. Prof. Lineu Prestes, 1524, 05508-900 São Paulo, Brazil. Tel.: +55 113091 7946; fax: +55 1130913798 .

E-mail address: wtavares@usp.br (W. Tavares-de-Lima).
}

resins and building materials, such as particle board, plywood, floor coverings and office furniture (Fló-Neyret et al., 2001; Krakowiak et al., 1998). FA exposure exacerbates asthma symptoms (Casset et al., 2005) and increases anti-FA antibody titres (Baba et al., 2000). Using a rat model of allergic lung disease, we recently reported that allergic rats previously subjected to FA inhalation developed less intense lung inflammation. We inferred that the reduced cell migration into the lung induced by FA exposure could impair the ability of mast cells to properly degranulate after the antigen challenge (Lino-dos-Santos-Franco et al., 2009). We also showed that IgE synthesis was not affected by FA exposure (Lino-dos-Santos-Franco et al., 2009).

The mechanisms whereby FA inhalation exerts its effects on allergic lung inflammation are not completely understood. In recent 


\title{
Pivotal Role of Toll-Like Receptors 2 and 4, Its Adaptor Molecule MyD88, and Inflammasome Complex in Experimental Tubule-Interstitial Nephritis
}

\author{
Matheus Correa-Costa', Tarcio Teodoro Braga', Patricia Semedo ${ }^{2}$, Caroline Yuri Hayashida ${ }^{1}$, Luiz \\ Roberto Grassmann Bechara ${ }^{3}$, Rosa Maria Elias ${ }^{2}$, Claudiene Rodrigues Barreto ${ }^{2}$, Claudia Silva-Cunha ${ }^{1}$, \\ Meire loshie Hyane ${ }^{1}$, Giselle Martins Gonçalves ${ }^{1}$, Patricia Chakur Brum ${ }^{3}$, Clarice Fujihara ${ }^{4}$, Roberto \\ Zatz $^{4}$, Alvaro Pacheco-Silva ${ }^{2,5}$, Dario S. Zamboni ${ }^{6}$, Niels Olsen Saraiva Camara ${ }^{1,2 *}$ \\ 1 Laboratory of Transplantation Immunobiology, Department of Immunology, Institute of Biomedical Sciences IV, University of São Paulo, São Paulo, Brazil, 2 Laboratory \\ of Clinical and Experimental Immunology, Nephrology Division, Federal University of São Paulo, São Paulo, Brazil, 3 School of Physical Education and Sport, University of \\ Sao Paulo, São Paulo, Brazil, 4 Renal Division, Department of Clinical Medicine, Faculty of Medicine, University of São Paulo, São Paulo, Brazil, 5 Instituto Israelita de Ensino \\ e Pesquisa Albert Einstein. Renal Transplantation Unit, Albert Einstein Hospital, São Paulo, Brazil, 6 Department of Cell Biology, Medical School Ribeirão Preto, Universidade \\ de São Paulo, São Paulo, Brazil
}

\begin{abstract}
Tubule-interstitial nephritis (TIN) results in decreased renal function and interstitial inflammation, which ultimately leads to fibrosis. Excessive adenine intake can cause TIN because xanthine dehydrogenase (XDH) can convert this purine into an insoluble compound, which precipitates in the tubuli. Innate immune sensors, such as Toll-like receptors (TLR) and inflammasome complex, play a crucial role in the initiation of inflammation. The aim of this study was to evaluate the roles of TLR-2 and -4, Myd88 and inflammasome complex in an experimental model of TIN. Here, we show that wild-type (WT) mice fed adenine-enriched food exhibited significant renal dysfunction and enhanced cellular infiltration accompanied by collagen deposition. They also presented higher gene and protein expression of pro-inflammatory cytokines. In contrast, TLR-2, -4, MyD88, ASC and Caspase-1 KO mice showed renoprotection associated with expression of inflammatory molecules at levels comparable to controls. Furthermore, treatment of WT animals with allopurinol, an XDH inhibitor, led to reduced levels of uric acid, oxidative stress, collagen deposition and a downregulation of the NF-kB signaling pathway. We concluded that MyD88 signaling and inflammasome participate in the development of TIN. Furthermore, inhibition of XDH seems to be a promising way to therapeutically target the developing inflammatory process.
\end{abstract}

Citation: Correa-Costa M, Braga TT, Semedo P, Hayashida CY, Bechara LRG, et al. (2011) Pivotal Role of Toll-Like Receptors 2 and 4, Its Adaptor Molecule MyD88, and Inflammasome Complex in Experimental Tubule-Interstitial Nephritis. PLoS ONE 6(12): e29004. doi:10.1371/journal.pone.0029004

Editor: Jörn Coers, Duke University Medical Center, United States of America

Received June 16, 2011; Accepted November 18, 2011; Published December 14, 2011

Copyright: (c) 2011 Correa-Costa et al. This is an open-access article distributed under the terms of the Creative Commons Attribution License, which permits unrestricted use, distribution, and reproduction in any medium, provided the original author and source are credited.

Funding: This work was supported by Fundação de Amparo à Pesquisa do Estado de São Paulo (07/07139-3 and 09/54474-8), Coordenação de Aperfeiçoamento de Pessoal de Nível Superior/Programa Nacional de Pós Doutorado, National Institute for Science and Technology - Complex Fluids and Conselho Nacional de Desenvolvimento Científico e Tecnológico. The funders had no role in study design, data collection and analysis, decision to publish, or preparation of the manuscript.

Competing Interests: The authors have declared that no competing interests exist.

*E-mail: niels@icb.usp.br

\section{Introduction}

Tubule-interstitial nephritis (TIN) is a common, but underestimated, disease characterized by acute inflammatory infiltrates associated with deterioration in renal function. If the causative stimulus persists, the disease process can worsen and cause fibrosis deposition and tubular damage [1]. Adenine-enriched food is an experimental model of TIN in which there is an excess of this purine, thus allowing it to become a substrate for xanthine dehydrogenase $(\mathrm{XDH})$. XDH converts adenine to 2,8-dihydroxyadenine (DHA), an insoluble compound that precipitates in the tubule-interstitial compartment, and causes nephrolithiasis followed by extensive tubular dilation, necrosis and apoptosis $[2,3]$. Consequently, the presence of damaged tissue initiates an intense inflammatory process, which apparently contributes to the progression of the disease [4].

Toll-like receptors (TLRs) are sensors of the innate immune system that recognize pathogen-associated molecular patterns and injured tissue signals, which are called damage-associated molecular patterns (DAMPs). Activation of TLRs induces a proinflammatory cascade, with downstream participation of $\mathrm{NF}-\kappa \mathrm{B}$ target genes [5]. Furthermore, the activation of intracellular sensors such as NOD-like receptors, for example, NLRP3, leads to the formation of the inflammasome complex by converting procaspase- 1 into active caspase- 1 , which in turn results in secretion of IL-1 $\beta$, IL-18 and IL-33 [6]. The adaptor molecule ASC plays an important role in this process because it recruits activated NLRP3 and caspase- 1 to form the inflammasome complex [7]. These innate immune elements have been widely recognized to be some of the molecules involved in acute and chronic kidney diseases $[4,8,9]$, however, it is still unclear whether they actively participate in the development of TIN

Therefore, we hypothesize that TLR-2, -4 and MyD88, as well as inflammasome complex elements, play an important role in our experimental model of TIN. 


\title{
$W\left(N^{\text {World Journal of }}\right.$ Nephrology
}

Online Submissions: http:/ / www.wjgnet.com/2220-6124office wjnephrol@wjgnet.com doi:10.5527/wjn.v1.i1.4

World J Nephrol 2012 February 6; 1(1): 4-11 ISSN 2220-6124 (online) (C) 2012 Baishideng. All rights reserved.

\section{Cytoprotection behind heme oxygenase-1 in renal diseases}

\author{
Matheus Correa-Costa, Mariane Tami Amano, Niels Olsen Saraiva Câmara
}

Matheus Correa-Costa, Mariane Tami Amano, Niels Olsen Saraiva Câmara, Laboratory of Transplantation Immunobiology, Department of Immunology, Institute of Biomedical Sciences IV, University of São Paulo, 05508-000, São Paulo, Brazil

Author contributions: Correa-Costa M and Amano MT wrote the manuscript; Câmara NOS wrote and corrected the manuscript; Correa-Costa M and Amano MT contributed equally to the work.

Supported by FAPESP (07/07139-3 and 09/54474-8), CAPES/ PNPD, INCT Complex Fluids and CNPq

Correspondence to: Niels Olsen Saraiva Câmara, MD, Full Professor, Head, Laboratory of Transplantation Immunobiology, Department of Immunology, Institute of Biomedical Sciences IV, University of São Paulo, Cidade Universitária, Av.Prof. Lineu Prestes, 173, 05508-000, São Paulo, Brazil. niels@icb.usp.br Telephone: +55-11-30917388 Fax: +55-11-55739652

Received: October 9, 2011 Revised: October 27, 2011

Accepted: December 27, 2011

Published online: February 6, 2012

\begin{abstract}
Renal insults are considered a public health problem and are linked to increased rates of morbidity and mortality worldwide. The heme oxygenase (HO) system consists of evolutionary specialized machinery that degrades free heme and produces carbon monoxide, biliverdin and free iron. In this sense, the inducible isoform HO-1 seems to develop an important role and is widely studied. The reaction involved with the HO-1 molecule provides protection to injured tissue, directly by reducing the toxic heme molecule and indirectly by the release of its byproducts. The up regulation of $\mathrm{HO}-1$ enzyme has largely been described as providing antioxidant, antiapoptotic, anti-inflammatory and immunomodulatory properties. Several works have explored the importance of $\mathrm{HO}-1$ in renal diseases and they have provided consistent evidence that its overexpression has beneficial effects in such injuries. So, in this review we will focus on the role of HO-1 in kidney insults, exploring the protective effects of its up regulation and the enhanced deleterious effects of its inhibition or gene deletion.
\end{abstract}

(c) 2012 Baishideng. All rights reserved.

Key words: Heme oxigenase-1; Renal cytoprotection; Antioxidants; Anti-inflammatory; Renal diseases

Peer reviewer: Dominique Guerrot, $\mathrm{MD}, \mathrm{PhD}$, Nephrology Department - Rouen University Hospital, 1 Avenue de Germont, 76031 Rouen, France

Correa-Costa M, Amano MT, Câmara NOS. Cytoprotection behind heme oxygenase-1 in renal diseases. World J Nephrol 2012; 1(1): 4-11 Available from: URL: http://www.wjgnet. com/2220-6124/full/v1/i1/4.htm DOI: http://dx.doi.org/10.5527/ wjn.v1.i1.4

\section{INTRODUCTION}

Renal injuries can occur as a consequence of a number of factors, like hypoxia, nephrotoxicity, diabetes, reninangiotensin system activation, among others. Most of these lesions are characterized by an increased amount of oxidative stress, inflammatory milieu and pro fibrotic stimuli. These factors lead to a breakdown of renal homeostasis and promote cell damage, with increased cell death and/or transdifferentiation. The ability of reducing this cellular damage could be crucial to a better outcome of the disease and, in this manner, the enzyme heme oxygenase (HO) could provide an important protective effect against renal insult ${ }^{[1]}$.

Heme molecule (iron protoporphyrin IX) represents the prosthetic group of various proteins and enzymes, including hemoglobin, nitric oxide synthase, cytochrome P-450, cyclooxygenase, and catalase, among others. It is involved in critical functions, such as oxygen supply, mitochondrial respiratory burst and signal transduction ${ }^{[2,3]}$. In this sense, $\mathrm{HO}$ is the rate limiting enzyme responsible for heme degradation. HO cleaves to the heme ring in a reaction requiring oxygen and nicotinamide adenine dinucleotide phosphate and, as a result, biliverdin is produced, releasing iron and carbon monoxide (CO) in equimolar 


\title{
Inflammatory milieu as an early marker of kidney injury in offspring rats from diabetic mothers ${ }^{2 / 3}$
}

\author{
Matheus Correa-Costa ${ }^{\mathrm{a}, 1}$, Maristella A. Landgraf ${ }^{\mathrm{a}, 1}$, Maria F. Cavanal ${ }^{\mathrm{b}}$, Patricia Semedo ${ }^{\mathrm{c}}$, \\ Daniel A.G. Vieira ${ }^{\mathrm{b}}$, Davi T.K. De Marco ${ }^{\mathrm{b}}$, Aparecida E. Hirata ${ }^{\mathrm{b}}$, Niels O.S. Câmara ${ }^{\mathrm{a}, \mathrm{c}, *, 1}$, Frida Z. Gil $^{\mathrm{b}, 1}$ \\ a Department of Immunology, Institute of Biomedical Sciences IV, University of São Paulo (USP), 05508-000 São Paulo, Brazil \\ b Department of Physiology, Federal University of São Paulo, São Paulo 04039-000, Brazil \\ c Nephrology Division, Federal University of São Paulo (UNIFESP), São Paulo 04039-001, Brazil
}

\section{A R T I C L E I N F O}

\section{Article history:}

Received 23 November 2011

Received in revised form 29 April 2012

Accepted 15 May 2012

Available online 28 May 2012

\section{Keywords:}

Fetal programming

Maternal diabetes

Renal inflammation

L-arginine

\begin{abstract}
A B S T R A C T
The present study investigated the early presence of inflammatory response in renal tissue of young offspring from diabetic mothers. The effect of L-arginine ( $\mathrm{L}-\mathrm{arg}$ ) supplementation was also investigated. The offspring was divided into four groups: group CO (controls); group DO (diabetic offspring); group CA (CO receiving $2 \%$ L-arg solution) and group DA (DO receiving the $2 \%$ L-arg solution). Glycemia, arterial pressure and renal function were evaluated; gene and protein expression of pro-inflammatory cytokines were also measured. Blood pressure levels were significantly increased in 2 and 6 month-old DO rats, whereas L-arg administration caused a significant decrease in the DA group, at both ages. DO rats showed a significantly blunted glycemic response to exogenous insulin. In 2 month-old DO animals, renal protein expression of pro-inflammatory molecules was significantly increased. At six months of age, we also observed an increase in gene expression of pro-inflammatory molecules, whereas L-arg supplementation prevented this increase at both ages. Our data suggest that activation of inflammatory pathways is present early in the kidney of DO rats, and that L-arg can attenuate the expression of these markers of tissue inflammation. Our results also reinforce the concept that intrauterine environmental factors are a fundamental determinant in the development of metabolic and vascular diseases later in life.
\end{abstract}

(c) 2012 Elsevier B.V. All rights reserved.

\section{Introduction}

Gestational diabetes mellitus can impose several threats both to the mother and to the conceptus. Diabetic pregnancy increases the risk of intrauterine death, prematurity, perinatal mortality and congenital malformations (Lynch and Wright, 1997; Martinez-Frias, 1994; Nold and Georgieff, 2004). It has also been demonstrated by both epidemiological and experimental studies that the offspring of diabetic mothers has an increased risk for development of cardiovascular disease and insulin resistance in adulthood (Boloker et al., 2002; Carlsson et al., 1999; Holemans

\footnotetext{
This study was supported by the Fundação de Amparo à Pesquisa do Estado de São Paulo (Grant numbers: 2007/07139-3, 2010/17782-3, 2012/02270-2 and 2010/52180-4), the Conselho Nacional de Desenvolvimento Científico e Tecnológico (CNPq) and the Instituto Nacional de Ciência e Tecnologia de Fluídos Complexos (INCT Complex Fluids).

* Correspondence to: Laboratory of Transplantation Immunobiology, Department of Immunology, Institute of Biomedical Sciences IV, University of São Paulo, 05508-000 Av Prof Lineu Prestes, 1730 SP, Brazil. Tel./fax: +55 1130917388 .

E-mail address: niels@icb.usp.br (N.O.S. Câmara).

${ }^{1}$ The authors contributed equally to the work.
}

et al., 1999; Manderson et al., 2002; Pettitt et al., 1983). In previous studies, we have demonstrated that maternal diabetes promotes remarkable changes in kidney morphology and function and in vascular reactivity in mature offspring (Rocha et al., 2005). In young animals, we found an altered response to a glucose tolerance test and an inability to excrete a salt overload (Magaton et al., 2007; Rocco et al., 2008). Our previous study showed that in the diabetic offspring model, the early onset of hypertension was, at least partially, related to an insufficient basal production of nitric oxide (NO), since after the administration of L-arginine ( $\mathrm{L}-\mathrm{arg}$ ) blood pressure levels and vascular reactivity returned to normal levels (Cavanal Mde et al., 2007).

Activation of inflammatory pathways has been demonstrated in several pathologies, among them metabolic and cardiovascular diseases. Insulin resistance, impaired endothelium-dependent relaxation and up-regulation of inflammatory markers were shown to be present in spontaneously hypertensive rats (SHR) and in a salt-sensitive model of hypertension, the Dahl rats (Delano et al., 2010; Potenza et al., 2005; Zhou et al., 2010). In these hypertensive states, free radical production is enhanced (DeLano et al., 2005; Swei et al., 1999). On the other hand, alterations in NO synthase (NOS) isoforms in brain and kidney 


\title{
TLR2, TLR4 and the MYD88 Signaling Pathway Are Crucial for Neutrophil Migration in Acute Kidney Injury Induced by Sepsis
}

\author{
Angela Castoldi ${ }^{1,2}$, Tárcio Teodoro Braga ${ }^{2}$, Matheus Correa-Costa ${ }^{2}$, Cristhiane Fávero Aguiar ${ }^{1}$, Ênio \\ José Bassi' ${ }^{2}$, Reinaldo Correa-Silva ${ }^{1}$, Rosa Maria Elias' ${ }^{1}$, Fábia Salvador ${ }^{1}$, Pedro Manoel Moraes-Vieira ${ }^{2}$, \\ Marcos Antônio Cenedeze', Marlene Antônia Reis ${ }^{4}$, Meire loshie Hiyane ${ }^{2}$, Álvaro Pacheco-Silva ${ }^{1,3}$, \\ Giselle Martins Gonçalves ${ }^{2}$, Niels Olsen Saraiva Câmara ${ }^{1,2 *}$
}

1 Disciplina de Nefrologia, Departamento de Medicina, Universidade Federal de São Paulo, São Paulo, Brazil, 2 Laboratório de Imunobiologia de Transplantes, Departamento de Imunologia, Universidade de São Paulo, São Paulo, Brazil, 3 IIEP, Hospital Israelita Albert Einstein, São Paulo, Brazil, 4 Patologia, Universidade Federal do Triângulo Mineiro, Uberaba, Brazil

\begin{abstract}
The aim of this study was to investigate the role of TLR2, TLR4 and MyD88 in sepsis-induced AKI. C57BL/6 TLR2 ${ }^{-1-}$, TLR4 ${ }^{-1-}$ and ${\mathrm{MyD} 88^{-1-}}$ male mice were subjected to sepsis by cecal ligation and puncture (CLP). Twenty four hours later, kidney tissue and blood samples were collected for analysis. The TLR2 ${ }^{-1-}$, TLR4 ${ }^{-1-}$ and MyD88 $8^{-1-}$ mice that were subjected to CLP had preserved renal morphology, and fewer areas of hypoxia and apoptosis compared with the wild-type C57BL/6 mice (WT). MyD88 ${ }^{-1-}$ mice were completely protected compared with the WT mice. We also observed reduced expression of proinflammatory cytokines in the kidneys of the knockout mice compared with those of the WT mice and subsequent inhibition of increased vascular permeability in the kidneys of the knockout mice. The WT mice had increased GR $1^{\text {+low }}$ cells migration compared with the knockout mice and decreased in $\mathrm{GR} 1^{\text {thigh }}$ cells migration into the peritoneal cavity. The $\mathrm{TLR}^{-/-}, \mathrm{TLR}^{-1-}$, and MyD88 ${ }^{-/-}$mice had lower neutrophil infiltration in the kidneys. Depletion of neutrophils in the WT mice led to protection of renal function and less inflammation in the kidneys of these mice. Innate immunity participates in polymicrobial sepsis-induced AKI, mainly through the MyD88 pathway, by leading to an increased migration of neutrophils to the kidney, increased production of proinflammatory cytokines, vascular permeability, hypoxia and apoptosis of tubular cells.
\end{abstract}

Citation: Castoldi A, Braga TT, Correa-Costa M, Aguiar CF, Bassi ÊJ, et al. (2012) TLR2, TLR4 and the MYD88 Signaling Pathway Are Crucial for Neutrophil Migration in Acute Kidney Injury Induced by Sepsis. PLoS ONE 7(5): e37584. doi:10.1371/journal.pone.0037584

Editor: Holger K. Eltzschig, University of Colorado Denver, United States of America

Received January 23, 2012; Accepted April 22, 2012; Published May 24, 2012

Copyright: (c) 2012 Castoldi et al. This is an open-access article distributed under the terms of the Creative Commons Attribution License, which permits unrestricted use, distribution, and reproduction in any medium, provided the original author and source are credited.

Funding: This work was supported by the Brazilian Foundation - Fundação de Apoio à Pesquisa do Estado de São Paulo (FAPESP), Grants Number: 07/07139-3), International Associated Laboratory (CNPq- National Counsel of Technological and Scientific Development), and National Institute of Science and Technology (INCT) Complex Fluids. The funders had no role in study design, data collection and analysis, decision to publish, or preparation of the manuscript.

Competing Interests: The authors have declared that no competing interests exist.

*E-mail: niels@icb.usp.br

\section{Introduction}

Severe sepsis is the major cause of acute kidney injury (AKI) (2 4). Despite all efforts to better comprehend this pathology, little progress has been achieved. This might be due to the fact that most research groups have focused more on proving that AKI is mainly caused by changes in kidney hemodynamics, while other groups have shown the importance of non-hemodynamic factors in the establishment of this disease, such as immunological factors $[1,2]$. The kidney damage after sepsis is likely a result of these two important contributions, starting with the recognition of bacterial products by Toll-like receptors (TLRs), which recognize pathogens, such as PAMPs (pathogen associated molecular patterns) and are responsible for the inflammatory cascade in sepsis.

Signal transduction through TLRs is partially mediated by a TLR adapter protein MyD88 (Myeloid Differentiation Factor 88). MyD88 can bind to the TIR domain and recruit signaling proteins, leading to the activation of transcription factors, such as NF-кB (Nuclear Factor-kappa B) and AP-1 (Activator Protein 1), and the expression of genes related to the inflammatory response, such as tubular necrosis factor TNF- $\alpha$, interleukin- 6 and IL- $1 \beta$.

Several studies have shown the importance of TLRs in the development of sepsis, but few studies have correlated the activation of TLRs with the development of AKI. During sepsis, TLRs are activated by bacteria and endogenous ligands such as HMGB-1 and HSP70, which are released during cellular stress, and interact with the immune system in the extracellular environment [3,4]. These alarmins exacerbate the kidney inflammatory process during sepsis, which results in greater damage and necrosis.

Thus, we hypothesized that mice deficient in TLR2 and TLR4 and the adaptor protein MyD88 respond less effectively to bacteria, leading to a milder inflammatory process and therefore weaker protection of renal function compared with wild-type mice. 


\title{
MyD88 Signaling Pathway Is Involved in Renal Fibrosis by Favoring a $\mathrm{T}_{\mathrm{H}} 2$ Immune Response and Activating Alternative M2 Macrophages
}

\author{
Tarcio Teodoro Braga, ${ }_{1}$ Matheus Correa-Costa, ${ }^{1}$ Yuri Felipe Souza Guise, ${ }^{1}$ Angela Castoldi, \\ Cassiano Donizetti de Oliveira, ${ }^{2}$ Meire Ioshie Hyane, ${ }_{1}^{1}$ Marcos Antonio Cenedeze, \\ Simone Aparecida Teixeira, ${ }^{3}$ Marcelo Nicolas Muscara, ${ }_{3}^{3}$ Katia Regina Perez, ${ }_{4}^{4}$ Iolanda Midea Cuccovia, \\ Alvaro Pacheco-Silva, ${ }^{2}$ Giselle Martins Gonçalves, ${ }^{1}$ and Niels Olsen Saraiva Camara ${ }^{1,2}$
}

${ }^{1}$ Laboratory of Transplantation Immunobiology, Department of Immunology, Institute of Biomedical Sciences IV, University of São Paulo (USP), São Paulo, Brazil; ${ }^{2}$ Laboratory of Clinical and Experimental Immunology, Nephrology Division, Federal University of São Paulo (UNIFESP), São Paulo, Brazil; ${ }^{3}$ Department of Pharmacology, Institute of Biomedical Sciences; and ${ }^{4}$ Department of Biochemistry, Institute of Chemistry, University of São Paulo (USP), São Paulo, Brazil

\begin{abstract}
Inflammation contributes to the pathogenesis of chronic kidney disease (CKD). Molecules released by the inflamed injured tissue can activate toll-like receptors (TLRs), thereby modulating macrophage and CD4 ${ }^{+}$T-cell activity. We propose that in renal fibrogenesis, M2 macrophages are recruited and activated in a T helper subset 2 cell $\left(T_{H} 2\right)$-prone inflammatory milieu in a MyD88dependent manner. Mice submitted to unilateral ureteral ligation (UUO) demonstrated an increase in macrophage infiltration with collagen deposition after $7 \mathrm{~d}$. Conversely, TLR2, TLR4 and MyD88 knockout (KO) mice had an improved renal function together with diminished $\mathrm{T}_{\mathrm{H}} 2$ cytokine production and decreased fibrosis formation. Moreover, TLR2, TLR4 and MyD88 KO animals exhibited less M2 macrophage infiltration, namely interleukin (IL)- $10^{+}$and CD206 ${ }^{+} \mathrm{CD} 11 \mathrm{~b}^{\text {high }}$ cells, at $7 \mathrm{~d}$ after surgery. We evaluated the role of a $\mathrm{T}_{\mathrm{H}} 2$ cytokine in this context, and observed that the absence of IL-4 was associated with better renal function, decreased IL-13 and TGF$\beta$ levels, reduced arginase activity and a decrease in fibrosis formation when compared with IL-12 KO and wild-type (WT) animals. Indeed, the better renal outcomes and the decreased fibrosis formation were restricted to the deficiency of IL-4 in the hematopoietic compartment. Finally, macrophage depletion, rather than the absence of T cells, led to reduced lesions of the glomerular filtration barrier and decreased collagen deposition. These results provide evidence that future therapeutic strategies against renal fibrosis should be accompanied by the modulation of the $\mathrm{M} 1: \mathrm{M} 2$ and $\mathrm{T}_{H} 1: \mathrm{T}_{H} 2$ balance, as $\mathrm{T}_{H} 2$ and $\mathrm{M} 2$ cells are predictive of fibrosis toward mechanisms that are sensed by innate immune response and triggered in a MyD88-dependent pathway.
\end{abstract}

Online address: http://www.molmed.org

doi: $10.2119 / \mathrm{molmed} .2012 .00131$

\section{INTRODUCTION}

Chronic kidney disease (CKD) is a major health problem, highly prevalent in the general population, and associated with a high mortality rate mainly due to cardiovascular complications (1). Several animal models have been used to study different features of CKD (2), and the use of genetically engineered mice has greatly expanded the utility of this model in studying molecular mechanisms underlying the renal response to chronic insults (3). Specifically, unilateral ureteral ligation (UUO) induces, after a

Address correspondence to Niels Olsen Saraiva Câmara, Department of Immunology, Institute of Biomedical Sciences, University of São Paulo, Cidade Universitária, Av. Prof. Lineu Prestes, 1730, 05508-900, São Paulo, Brazil. Phone: +55-17-3091-7388; Fax: +55-1 1-30917224; E-mail: niels@icb.usp.br.

Submitted March 21, 2012; Accepted for publication July 5 2012; Epub (www.molmed.org) ahead of print July 5, 2012.

The Feinstein Institute for Medical Research Shore LIJ

few hours, cellular infiltration into the kidney, mainly macrophages that secrete growth factors and cytokines that ultimately induce disequilibrium between apoptosis and proliferation of the tubular cells, which favors fibroblast activation and proliferation. Activated fibroblasts secrete additional extracellular matrix (ECM) components that accumulate in the interstitium, and, as the obstruction continues, ECM deposition becomes massive, and the uncontrolled apoptosis of cells results in tubular atrophy (3). This matrix remodeling and cellular stress can release molecules that finally instigate an inflammatory response.

Toll-like receptors (TLRs) are an innate family of receptors that can sense tissue 


\title{
Oxidative Stress and Modification of Renal Vascular Permeability Are Associated with Acute Kidney Injury during $P$. berghei ANKA Infection
}

\author{
Rosa Maria Elias ${ }^{1}$, Matheus Correa-Costa ${ }^{2}$, Claudiene Rodrigues Barreto ${ }^{1}$, Reinaldo Correia Silva ${ }^{1}$, \\ Caroline Y. Hayashida ${ }^{2}$, Ângela Castoldi ${ }^{1}$, Giselle Martins Gonçalves ${ }^{2}$, Tarcio Teodoro Braga ${ }^{2}$, \\ Renato Barboza ${ }^{6}$, Francisco José Rios ${ }^{2}$, Alexandre Castro Keller ${ }^{3}$, Marcos Antonio Cenedeze ${ }^{1}$, Meire \\ loshie Hyane ${ }^{2}$, Maria Regina D'Império-Lima ${ }^{2}$, Antônio Martins Figueiredo-Neto ${ }^{4}$, Marlene Antônia Reis ${ }^{5}$, \\ Cláudio Romero Farias Marinho ${ }^{6}$, Alvaro Pacheco-Silva ${ }^{1,7}$, Niels Olsen Saraiva Câmara ${ }^{1,2 *}$
}

1 Disciplina de Nefrologia, Departamento de Medicina, Universidade Federal de São Paulo, São Paulo, Brazil, 2 Laboratório de Imunobiologia de Transplantes, Departamento de Imunologia, Universidade de São Paulo, São Paulo, Brazil, 3 Departamento de Imunologia, Universidade Federal de São Paulo, São Paulo, Brazil, 4 Instituto de Física, Universidade de São Paulo, São Paulo, Brazil, 5 Divisão de Patologia, Universidade Federal do Triângulo Mineiro, Uberaba, Brazil, 6 Departamento de Parasitologia, Instituto de Ciências Biomédicas, Universidade de São Paulo, São Paulo, Brazil, 7 Instituto Israelita de Ensino e Pesquisa Albert Einstein, São Paulo, Brazil

\begin{abstract}
Malaria associated-acute kidney injury (AKI) is associated with $45 \%$ of mortality in adult patients hospitalized with severe form of the disease. However, the causes that lead to a framework of malaria-associated AKI are still poorly characterized. Some clinical studies speculate that oxidative stress products, a characteristic of Plasmodium infection, as well as proinflammatory response induced by the parasite are involved in its pathophysiology. Therefore, we aimed to investigate the development of malaria-associated AKI during infection by $P$. berghei ANKA, with special attention to the role played by the inflammatory response and the involvement of oxidative stress. For that, we took advantage of an experimental model of severe malaria that showed significant changes in the renal pathophysiology to investigate the role of malaria infection in the renal microvascular permeability and tissue injury. Therefore, BALB/c mice were infected with $P$. berghei ANKA. To assess renal function, creatinine, blood urea nitrogen, and ratio of proteinuria and creatininuria were evaluated. The products of oxidative stress, as well as cytokine profile were quantified in plasma and renal tissue. The change of renal microvascular permeability, tissue hypoxia and cellular apoptosis were also evaluated. Parasite infection resulted in renal dysfunction. Furthermore, we observed increased expression of adhesion molecule, proinflammatory cytokines and products of oxidative stress, associated with a decrease mRNA expression of HO-1 in kidney tissue of infected mice. The measurement of lipoprotein oxidizability also showed a significant increase in plasma of infected animals. Together, our findings support the idea that products of oxidative stress, as well as the immune response against the parasite are crucial to changes in kidney architecture and microvascular endothelial permeability of BALB/c mice infected with $P$. berghei ANKA.
\end{abstract}

Citation: Elias RM, Correa-Costa M, Barreto CR, Silva RC, Hayashida CY, et al. (2012) Oxidative Stress and Modification of Renal Vascular Permeability Are Associated with Acute Kidney Injury during P. berghei ANKA Infection. PLoS ONE 7(8): e44004. doi:10.1371/journal.pone.0044004

Editor: Fabio T. M. Costa, State University of Campinas, Brazil

Received April 26, 2012; Accepted July 27, 2012; Published August 31, 2012

Copyright: (c) 2012 Elias et al. This is an open-access article distributed under the terms of the Creative Commons Attribution License, which permits unrestricted use, distribution, and reproduction in any medium, provided the original author and source are credited.

Funding: This study was supported by grants 07/07139-3, 10/52180-4 and 12/02270-2 from the State of Sao Paulo Foundation for Research Support (FAPESP) CAPES (PRODOC grant), Brazilian Council of Scientific and Technologic Development (International Associated Laboratory of Renal Immunopathology, CNPq/ Inserm) and Complex Fluids INCT (FAPESP/CNPq). The funders had no role in study design, data collection and analysis, decision to publish, or preparation of the manuscript.

Competing Interests: NOSC is a PLOS ONE Editorial Board member. The authors declare that this information does not alter the authors' adherence to all the PLoS ONE policies on sharing data and materials.

* E-mail: niels@icb.usp.br

\section{Introduction}

Every year, there are about 800 thousand people dying from severe form of malaria (World Malaria Report). Malariaassociated acute kidney injury (AKI), one of the three major lifethreatening well-know causes of death in P. falciparum [1,2] and $P$. vivax severe malaria $[3,4]$, occurs between $1-4 \%$ of hospitalized adult [5] with a mortality that can reach up to $45 \%$ [1]. The pathogenesis of malaria-associated AKI is multifactorial and not well characterized, but several hypotheses suggest involvement of cytoadherence of iRBC, proinflammatory response as well as nephrotoxicity due to oxidative stress. It is well-establish that pathogenesis of severe malaria is associated with an up regulation of proinflammatory cytokines [6,7]. During intra-erythrocytic phase, the consumption of hemoglobin by parasites gives rise of considerable amounts of free heme $\left(\mathrm{Fe}^{+3}\right)$, a molecule that have the ability to induce oxidative stress [8]. The oxidative stress mediated by free heme has been implicated in lipoprotein oxidation [9] and serious damage in different organs such as the kidneys [10] through generation of reactive oxygen intermediates, and nitrogen intermediates (ROI and NO) by host cells. Moreover, ox-LDL upregulates the expression of adhesion molecules, facilitating the cytoadherence of infected erythrocytes [11]. The sequestration and adhesion of infected red blood cells (iRBC) to endothelial cells 


\title{
Low-Level Laser Therapy Decreases Renal Interstitial Fibrosis
}

\author{
Fabiana Aparecida Mayrink Oliveira, M.D.,,2 Ana Carolina Meneghin Moraes, M.D.,,2 \\ Amanda Povoa Paiva, M.D., ${ }^{1,2}$ Vânia Schinzel, M.D., ${ }^{1,2}$ Matheus Correa-Costa, Ph.D., 3,4 \\ Patricia Semedo, Ph.D., ${ }^{4}$ Angêla Castoldi, B.S., M.Sc., ${ }^{4}$ Marcos Antonio Cenedeze, ${ }^{4}$ \\ Roberto Sotto-Maior Fortes Oliveira, Ph.D., ${ }^{2}$ Marcus Gomes Bastos, M.D., Ph.D., \\ Niels Olsen Saraiva Câmara, M.D., Ph.D., ${ }^{3,4}$ and Helady Sanders-Pinheiro, M.D., Ph.D. ${ }^{1-4}$
}

\begin{abstract}
Objective: the purpose of this study was to investigate the effect of low-level laser therapy (LLLT) on chronic kidney disease (CKD) in a model of unilateral ureteral obstruction (UUO). Background data: Regardless of the etiology, CKD involves progressive widespread tissue fibrosis, tubular atrophy, and loss of kidney function. This process also occurs in kidney allograft. At present, effective therapies for this condition are lacking. We investigated the effects of LLLT on the interstitial fibrosis that occurs after experimental UUO in rats. Methods: The occluded kidney of half of the 32 Wistar rats that underwent UUO received a single intraoperative dose of LLLT (AlGaAs laser, $780 \mathrm{~nm}, 22.5 \mathrm{~J} / \mathrm{cm}^{2}, 30 \mathrm{~mW}, 0.75 \mathrm{~W} / \mathrm{cm}^{2}, 30 \mathrm{sec}$ on each of nine points). After 14 days, renal fibrosis was assessed by Sirius red staining under polarized light. Immunohistochemical analyses quantitated the renal tissue cells that expressed fibroblast (FSP-1) and myofibroblast ( $\alpha$-SMA) markers. Reverse transcriptase polymerase chain reaction (RT-PCR) was performed to determine the mRNA expression of interleukin (IL)-6, monocyte chemotactic protein-1 (MCP-1), transforming growth factor (TGF)- $\beta 1$ and Smad3. Results: The UUO and LLLT animals had less fibrosis than the UUO animals, as well having decreased expression inflammatory and pro-fibrotic markers. Conclusions: For the first time, we showed that LLLT had a protective effect regarding renal interstitial fibrosis. It is conceivable that by attenuating inflammation, LLLT can prevent tubular activation and transdifferentiation, which are the two processes that mainly drive the renal fibrosis of the UUO model.
\end{abstract}

\section{Introduction}

C HRONIC KIDNEY DISEASE (CKD) is a devastating condition and a global public health problem. In the more advanced stage of CKD, patients become dependent on life-long dialysis treatment or require renal transplantation. The human and economic impact of CKD is enormous. ${ }^{1}$

Regardless of the etiology, the pathogenesis of CKD always results in a persistent chronic inflammation of the kidney tissue by pro-inflammatory mediators such as tumor necrosis factor (TNF)- $\alpha$, interleukin (IL)-1 $\beta$, IL-6, monocyte chemotactic protein-1 (MCP-1), and osteopontin. ${ }^{2,3}$ The kidneys experience progressive loss of function and inter- stitial fibrosis/tubular atrophy, which is characterized by accumulation of matrix proteins, such as collagen types I and III, metalloproteinases, fibronectin, and vimentin. ${ }^{4-6}$

Some evidence suggests that during renal injury, tubular epithelial cells can differentiate into myofibroblasts that express $\alpha$-smooth muscle actin ( $\alpha$-SMA) and fibroblasts that express fibroblast-specific protein-1 (FSP1), which is normally expressed by fibroblasts but not epithelial cells: this process is known as tubular epithelial-mesenchymal transition (EMT). ${ }^{7}$ The most important of these mediators appears to be the pro-fibrotic molecule transforming growth factor$\beta 1$ (TGF- $\beta 1) .{ }^{1}$ In chronic renal fibrosis, the intracellular signal transduction involved in TGF- $\beta 1$-induced EMT is

\footnotetext{
${ }^{1}$ Division of Nephrology, Federal University of Juiz de Fora, Juiz de Fora (UFJF), Brazil.

${ }^{2}$ Center of Reproductive Biology, Federal University of Juiz de Fora, Juiz de Fora (UFJF), Brazil.

${ }^{3}$ Laboratory of Transplantation Immunobiology, Department of Immunology, Institute of Biomedical Sciences IV, University of São Paulo (USP), São Paulo, Brazil.

${ }^{4}$ Laboratory of Clinical and Experimental Immunology, Nephrology Division, Federal University of São Paulo (UNIFESP), São Paulo, Brazil.
} 


\title{
Transcriptome Analysis of Renal Ischemia/Reperfusion Injury and Its Modulation by Ischemic Pre-Conditioning or Hemin Treatment
}

\author{
Matheus Correa-Costa ${ }^{19}$, Hátylas Azevedo ${ }^{29}$, Mariane Tami Amano ${ }^{1}$, Giselle Martins Gonçalves ${ }^{1}$, Meire \\ loshie Hyane', Marcos Antonio Cenedeze ${ }^{3}$, Paulo Guilherme Renesto ${ }^{1,3}$, Alvaro Pacheco-Silva ${ }^{3}$, Carlos \\ Alberto Moreira-Filho ${ }^{2 *}$, Niels Olsen Saraiva Câmara ${ }^{1,3_{*}}$
}

1 Laboratory of Transplantation Immunobiology, Department of Immunology, Instituto de Ciências Biomédicas, Universidade de São Paulo (USP), São Paulo, Brazil, 2 Laboratory of Pediatric Genomics, Department of Pediatrics, Faculdade de Medicina, Universidade de São Paulo (USP), São Paulo, Brazil, 3 Laboratory of Clinical and Experimental Immunology, Nephrology Division, Universidade Federal de São Paulo (UNIFESP), São Paulo, Brazil

\begin{abstract}
Ischemia/reperfusion injury (IRI) is a leading cause of acute renal failure. The definition of the molecular mechanisms involved in renal IRI and counter protection promoted by ischemic pre-conditioning (IPC) or Hemin treatment is an important milestone that needs to be accomplished in this research area. We examined, through an oligonucleotide microarray protocol, the renal differential transcriptome profiles of mice submitted to IRI, IPC and Hemin treatment. After identifying the profiles of differentially expressed genes observed for each comparison, we carried out functional enrichment analysis to reveal transcripts putatively involved in potential relevant biological processes and signaling pathways. The most relevant processes found in these comparisons were stress, apoptosis, cell differentiation, angiogenesis, focal adhesion, ECM-receptor interaction, ion transport, angiogenesis, mitosis and cell cycle, inflammatory response, olfactory transduction and regulation of actin cytoskeleton. In addition, the most important overrepresented pathways were MAPK, ErbB, JAK/STAT, Toll and Nod like receptors, Angiotensin II, Arachidonic acid metabolism, Wnt and coagulation cascade. Also, new insights were gained about the underlying protection mechanisms against renal IRI promoted by IPC and Hemin treatment. Venn diagram analysis allowed us to uncover common and exclusively differentially expressed genes between these two protective maneuvers, underscoring potential common and exclusive biological functions regulated in each case. In summary, IPC exclusively regulated the expression of genes belonging to stress, protein modification and apoptosis, highlighting the role of IPC in controlling exacerbated stress response. Treatment with the Hmox 1 inducer Hemin, in turn, exclusively regulated the expression of genes associated with cell differentiation, metabolic pathways, cell cycle, mitosis, development, regulation of actin cytoskeleton and arachidonic acid metabolism, suggesting a pleiotropic effect for Hemin. These findings improve the biological understanding of how the kidney behaves after IRI. They also illustrate some possible underlying molecular mechanisms involved in kidney protection observed with IPC or Hemin treatment maneuvers.
\end{abstract}

Citation: Correa-Costa M, Azevedo H, Amano MT, Gonçalves GM, Hyane MI, et al. (2012) Transcriptome Analysis of Renal Ischemia/Reperfusion Injury and Its Modulation by Ischemic Pre-Conditioning or Hemin Treatment. PLoS ONE 7(11): e49569. doi:10.1371/journal.pone.0049569

Editor: Emmanuel A. Burdmann, University of Sao Paulo Medical School, Brazil

Received July 26, 2012; Accepted October 10, 2012; Published November 14, 2012

Copyright: (c) 2012 Correa-Costa et al. This is an open-access article distributed under the terms of the Creative Commons Attribution License, which permits unrestricted use, distribution, and reproduction in any medium, provided the original author and source are credited.

Funding: This work was supported by Fundação de Amparo à Pesquisa do Estado de São Paulo-FAPESP (2007/07139-3, 2009/54474-8 and 2012/02270-2) and Conselho Nacional de Desenvolvimento Cientifico e Tecnológico - CNPq/International Associated Laboratory in Renal Physiopathology (CNPq/Inserm) and Complex Fluids INCT (CNPq/FAPESP). The funders had no role in study design, data collection and analysis, decision to publish, or preparation of the manuscript.

Competing Interests: The authors have declared that no competing interests exist.

*E-mail: niels@icb.usp.br (NOSC); carlos.moreira@hc.fm.usp.br (CAMF)

9 These authors contributed equally to this work.

\section{Introduction}

Ischemia/reperfusion injury (IRI) is a leading cause of acute renal failure (ARF), a common renal disease that is still associated with high mortality, despite significant advances in the healthcare system [1]. IRI is caused by a sudden transient drop in blood flow associated with a robust inflammatory and oxidative stress response to hypoxia and reperfusion, frequently occurring during shock, sepsis and transplantation [2]. Although important findings have been made in the definition of the cell biologic consequences of IRI $[3,4]$, there are still few therapies available for this clinical problem [5].
It is known that renal tubular cells response to IRI depends on the intensity and time period of ischemia. Also, many cell phenomena such as proliferation, dedifferentiation, loss of cell polarity and cell death are on tracking during renal IRI [6]. However, the underlying mechanisms participating in the adaptive response occurred along renal IRI need to be clarified in order to understand how to ameliorate the harmful consequences of IRI.

The kidney has the ability to be preconditioned by a non-lethal period of ischemia, which makes it refractory to subsequent ischemia-induced dysfunction in animal models [7]. The ischemic pre-conditioning (IPC) refers to brief episodes of ischemia followed by prolonged ischemia and reperfusion, which protects organs 


\title{
Acute Kidney Injury Reduces Phagocytic and Microbicidal Capacities of Alveolar Macrophages
}

\author{
Reinaldo C. Silva ${ }^{a}$ Maristella A. Landgraf ${ }^{b, c}$ Matheus Corrêa-Costa ${ }^{c}$ Patricia Semedo ${ }^{a}$

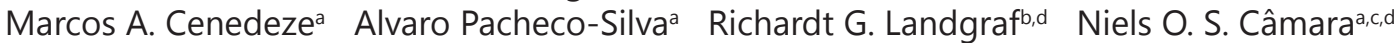 \\ aLaboratório de Imunologia Clínica e Experimental. Disciplina de Nefrologia,Universidade Federal \\ de São Paulo, São Paulo; 'Laboratório de Inflamação e Farmacologia Vascular, Instituto de Ciências \\ Ambientais, Químicas e Farmacêuticas, Universidade Federal de São Paulo-Campus Diadema, São \\ Paulo; 'Laboratorio de Imunobiologia do Transplante, Departamento de Imunologia, Instituto de \\ Ciências Biomédicas, Universidade de São Paulo, São Paulo, SP; ${ }^{\mathrm{d} B o t h}$ authors contributed equally
}

\section{Key Words}

Alveolar macrophages • Pulmonary inflammation • Killing • Klebsiella pneumonia • Ischaemia and reperfusion injury

\begin{abstract}
Background/Aims: Renal ischaemia-reperfusion injury (IRI) is a systemic inflammatory process in which Th1 responses predominate affecting other organs including the lungs. The present study explored the phagocytic and microbicidal capacity of macrophages in rats with lung inflammation that underwent IRI. Methods: The alveolar macrophages of rats sensitised to OVA were evaluated for phagocytosis and bacterial killing $24 \mathrm{~h}$ after antigen challenge in animals with or without prior submission to $60 \mathrm{~min}$ of renal ischaemia. Results: Bronchoalveolar lavage had a high level of cellular infiltrate in immunised animals (420\%) compared with control animals; IRI significantly reduced this infiltration (52\%). Macrophages from animals immunised and challenged with OVA presented a 10x increase in phagocytic capacity compared to the control group, whereas immunised animals subjected to IRI showed a reduction in the phagocytic index of $68 \%$. The killing of Klebsiella pneumoniae by macrophages from immunised animals was higher (56\%) compared with the control group but reduced in animals submitted to IRI (45\%). Immunised and challenged group showed an increase in gene expression levels of IL-10(450\%), HO-1 (259\%), INF- $\gamma(460 \%)$ and MCP-1 (370\%) compared to the immunised group subjected to IRI. Conclusions: Renal ischaemia and reperfusion injury apparently alters the phagocytic and microbicidal capacity of macrophages, reducing lung inflammation to OVA.
\end{abstract}




\section{AUTOCRINE ACTIVATION OF PLATELET-ACTIVATING FACTOR RECEPTOR EXACERBATES RENAL INFLAMMATION AND PROMOTES FIBROSIS}

Matheus Correa-Costa ${ }^{1}$, Vinicius Andrade-Oliveira ${ }^{1}$, Tarcio Teodoro Braga ${ }^{1}$, Angela Castoldi $^{1}$, Clarice Silvia Taemi Origassa ${ }^{2}$, Andrea Cecília Dorion Rodas $^{1}$, Meire loshie Hiyane ${ }^{1}$, Francisco Jose Oliveira Rios ${ }^{1,3}$, Sonia Jancar ${ }^{1}$, Niels Olsen Saraiva Câmara ${ }^{1,2}$

1. Department of Immunology, Institute of Biomedical Sciences, University of São Paulo, São Paulo, Brazil

2. Nephrology Division, Federal University of São Paulo, São Paulo, Brazil

3. British Heart Foundation, Glasgow Cardiovascular Research Centre, Institute of Cardiovascular and Medical Sciences, University of Glasgow, Glasgow, Scotland, UK.

Corresponding author: Matheus Correa-Costa

Department of Immunology, Institute of Biomedical Sciences, University of São Paulo, Cidade Universitária,

Av. Prof. Lineu Prestes, 173, 05508-900, São Paulo, Brazil

Phone: +55 $113091-7388$

Fax: +551155739652

Email: matheusccosta@usp.br

This study was supported by the Fundação de Amparo à Pesquisa do Estado de São Paulo (grants numbers: 2009/54474-8 and 2012/02270-2), Conselho Nacional de Desenvolvimento Científico e Tecnológico (CNPq) and Instituto Nacional de Ciência e Tecnologia de Fluídos Complexos (INCT Complex Fluids).

Running title: PAFR and renal fibrosis

Manuscript word count: 3150

Abstract word count: 195 


\section{Exogenous leptin down regulates LPS-induced acute lung injury}

Maristella A Landgraf ${ }^{1,2,3^{*}}$; Reinaldo C Silva ${ }^{4}$; Matheus Corrêa-Costa ${ }^{2}$; Meire I Hiyane ${ }^{2}$, Richardt G Landgraf ${ }^{3 a^{*}}$; Niels O S Câmara ${ }^{2,4 a}$.

${ }^{1}$ Laboratory of Hypertension, Dept of Pharmacology, Institute of Biomedical Sciences, University of São Paulo, São Paulo, Brazil; ${ }^{2}$ Laboratory of Transplantation Immunobiology, Dept of Immunology, Institute of Biomedical Sciences, University of São Paulo, São Paulo, Brazil; ${ }^{3}$ Laboratory of Inflammation and Vascular Pharmacology, Federal University of São Paulo-Campus Diadema, São Paulo, Brazil; ${ }^{4}$ Laboratory of Clinical and Experimental Immunobiology, Division of Nephrology, Federal University of São Paulo, São Paulo, Brazil.

-These authors contributed equally to this work

\section{Correspondence address to:}

*Dr. Maristella A Landgraf

Laboratory of Hypertension, Department of Pharmacology, Institute of Biomedical Sciences I, University of São Paulo, 05508-000, Av Prof Lineu Prestes, 1524 - SP Brazil. Phone: +55-11-3091-7237.

E-mail address: mvitta@usp.br

*Dr. Richardt G Landgraf

Laboratory of Inflammation and Vascular Pharmacology. Federal University of São Paulo - Campus Diadema, 09913-030, Rua São Nicolau, 210, Diadema, SP, Brazil. Phone/fax: +55-11-3319-3561.

E-mail address: rglandgraf@,unifesp.br 
"Administration of $\alpha$-Galactosylceramide improves renal injury through IFN- $\gamma$ pathway"

Authors: Cristhiane Favero Aguiar ${ }^{1}$, Angela Castoldi ${ }^{2}$, Matheus Corrêa-Costa ${ }^{2}$, Érika Lamkowski Naka ${ }^{1}$, Mariane Tami Amano ${ }^{2}$, Marcos Antonio Cenedeze ${ }^{1}$, Alvaro Pacheco e Silva Filho ${ }^{1,3}$, Niels Olsen Saraiva Câmara ${ }^{1,2}$.

Affiliation: (1) Laboratory of Clinical and Experimental Immunology, Nephrology Division, Federal University of São Paulo, Rua Pedro de Toledo, 669 - 04039-032 São Paulo-SP, Brazil.

(2) Laboratory of Transplantation Immunobiology, Department of Immunology, Institute of Biomedical Sciences IV, University of São Paulo, Av. Prof. Lineu Prestes,1730 - 05508-900 São Paulo-SP, Brazil.

(3) Instituto Israelita de Ensino e Pesquisa Albert Einstein. Renal Transplantation Unit, Albert Einstein Hospital, Av. Albert Einstein, 627/701 - 05652-900 São PauloSP, Brazil.

Corresponding author:

Prof. Dr. Niels Olsen Saraiva Câmara (niels@icb.usp.br)

Address: Institute of Biomedical Sciences IV, University of São Paulo, Av. Prof. Lineu Prestes, 1730 - CEP 05508-900 - São Paulo, SP, Brazil

Telephone: +55 1130917388 Fax: +55 1130917327

Manuscript word count: 2.772 words

Abstract word count: 233 words 
FORUM REVIEW ARTICLE

\title{
Heme Oxygenase-1: A Metabolic Nike
}

Barbara Wegiel $^{1 *}$, Zsuzsanna Nemeth ${ }^{1,2}$, Matheus Correa-Costa ${ }^{1}$ Andrew C. Bulmer ${ }^{3}$, Leo E. Otterbein ${ }^{1}$

\begin{abstract}
${ }^{1}$ Department of Surgery, Beth Israel Deaconess Medical Center, Harvard Medical School, Boston, MA 02215, ${ }^{2}$ Department of Tumor Biology, National Koranyi Institute of Pulmonology, Budapest, Hungary, ${ }^{3}$ Heart Foundation Research Centre, Griffith Health Institute, Griffith University, Queensland, Australia
\end{abstract}

\begin{abstract}
*Correspondence: Barbara Wegiel, PhD, Center for Life Sciences 601, 3 Blackfan Circle EC/CLS 601; 02215 MA, Boston; phone: 617-735-2846; fax: 617-735-2844 email: bwegiel@bidmc.harvard.edu
\end{abstract}

$\underline{\text { Running title: HO-1 and metabolism. }}$

Word count: 5387

Reference number: 123

Number of illustrations: 7 Figures and 2 Tables 